\title{
Coal Use in the People's Republic of China, Volume 2: The Economic Effects of Constraining Coal Utilization
}

by A. Rose," M.M. Tompkins, D. Lim, ${ }^{*}$ O. Frias, ${ }^{*}$ and J. Benavides*

Decision and Information Sciences Division,

Argonne National Laboratory, 9700 South Cass Avenue, Argonne, Illinois 60439

December 1994

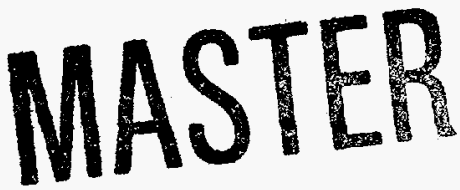

- Rose, Lim, Frias, and Benavides are affiliated with The Pennsylvania State University, Department of Mineral Economics, University Park, Pennsylvania 16802.<smiles>CC1C=CC1C</smiles> 


\section{DISCLAIMER}

This report was prepared as an account of work sponsored by an agency of the United States Government. Neither the United States Government nor any agency thereof, nor any of their employees, make any warranty, express or implied, or assumes any legal liability or responsibility for the accuracy, completeness, or usefulness of any information, apparatus, product, or process disclosed, or represents that its use would not infringe privately owned rights. Reference herein to any specific commercial product, process, or service by trade name, trademark, manufacturer, or otherwise does not necessarily constitute or imply its endorsement, recommendation, or favoring by the United States Government or any agency thereof. The views and opinions of authors expressed herein do not necessarily state or reflect those of the United States Government or any agency thereof. 


\section{DISCLAIMER}

Portions of this document may be illegible in electronic image products. Images are produced from the best available original document. 


\section{CONTENTS}

NOTATION $\ldots \ldots \ldots \ldots \ldots \ldots \ldots \ldots \ldots \ldots \ldots \ldots \ldots \ldots \ldots \ldots \ldots \ldots$ viii

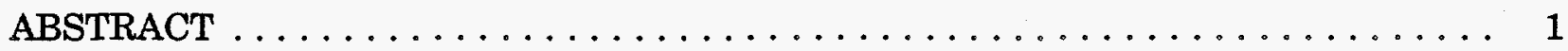

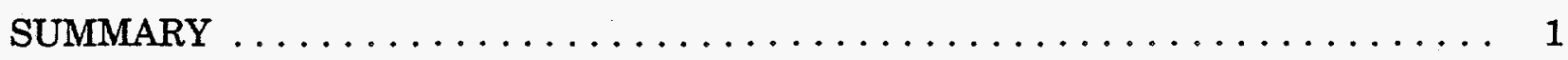

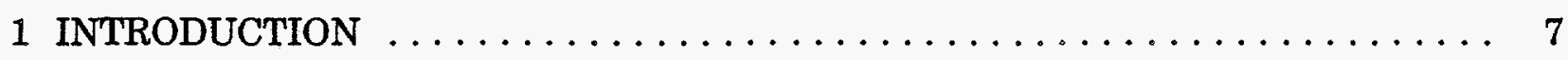

2 ENERGY IN CHINA $\ldots \ldots \ldots \ldots \ldots \ldots \ldots \ldots \ldots \ldots \ldots \ldots \ldots$

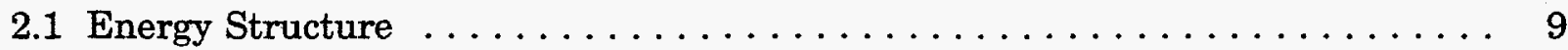

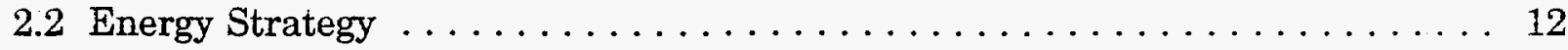

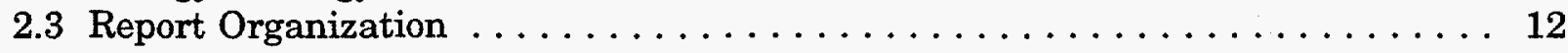

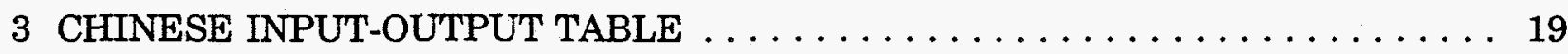

3.1 Introduction to Input-Output Analysis $\ldots \ldots \ldots \ldots \ldots \ldots \ldots \ldots$

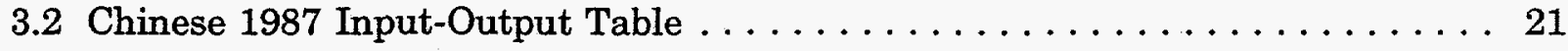

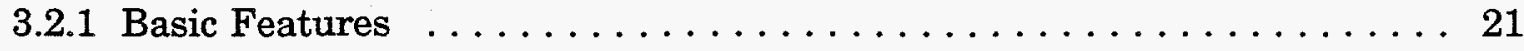

3.2.2 Summary Description of the 1987 Input-Output Table . . . . . . . 22

3.2.3 1990 Input-Output Transactions Table . . . . . . . . . . . . . 24

4 THE BASIC STRUCTURE OF CHINA'S DYNAMIC LINEAR PROGRAMMING MODEL $\ldots \ldots \ldots \ldots \ldots \ldots \ldots \ldots \ldots \ldots \ldots \ldots$

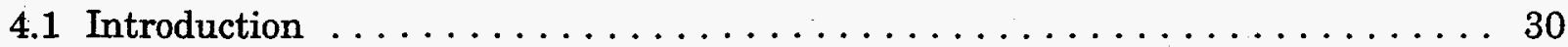

4.2 . Basic Model . . . . . . . . . . . . . . . . . . . . . . 32

4.3 Consistent Calculation of Growth Rates $\ldots \ldots \ldots \ldots \ldots \ldots \ldots \ldots$

4.4 Model Parameters . . . . . . . . . . . . . . . . . . . . . . 39

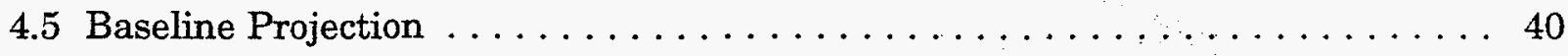

5 POLLUTION EMISSIONS, ENERGY RESERVES,

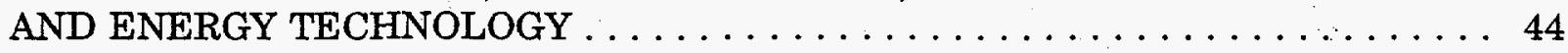

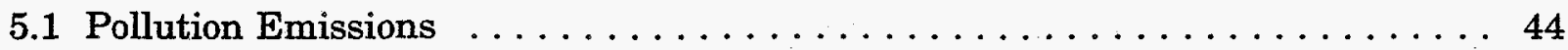

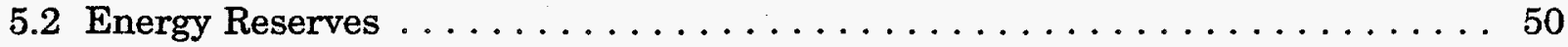

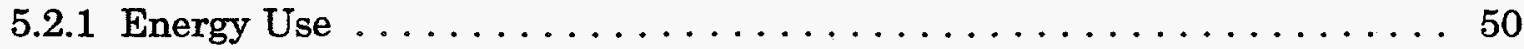

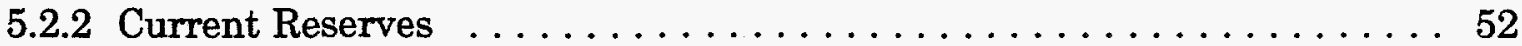

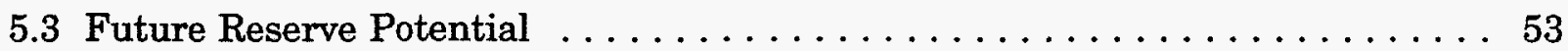

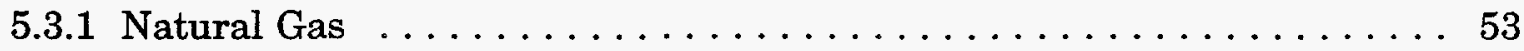

5.3 .2 Nuclear Power . . . . . . . . . . . . . . . . . . . 54

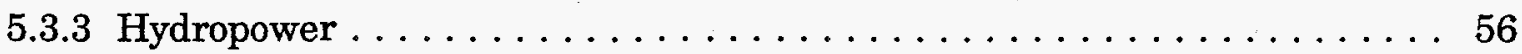

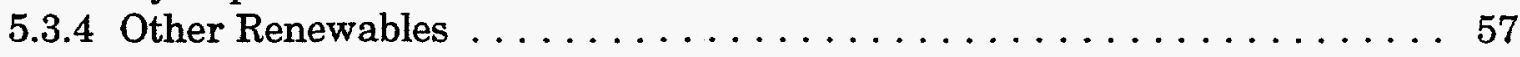

5.3 .5 Conservation . . . . . . . . . . . . . . . . . . . . 61

5.4 Upper-Bound Constraints on Energy and Technology . . . . . . . . . . 61

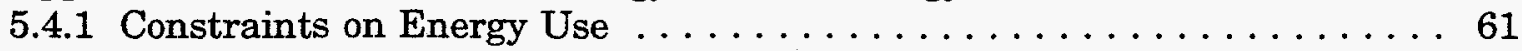

5.4 .2 Technological Trend Parameters $\ldots \ldots \ldots \ldots \ldots \ldots \ldots \ldots \ldots \ldots$ 


\section{CONTENTS (Cont.)}

5.5 Lower-Bound Constraints in Energy and Technology . . . . . . . . . . 65

5.5.1 Constraints on Energy Use . . . . . . . . . . . . . . . 65

5.5.2 Technological Trend Parameters $\ldots \ldots \ldots \ldots \ldots \ldots \ldots$

6 SIMULATION RESULTS $\ldots \ldots \ldots \ldots \ldots \ldots \ldots \ldots \ldots \ldots \ldots \ldots$

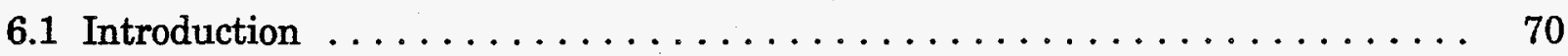

6.2 Simulations for the Year 2000: Upper-Bound Case $\ldots \ldots \ldots \ldots \ldots \ldots$

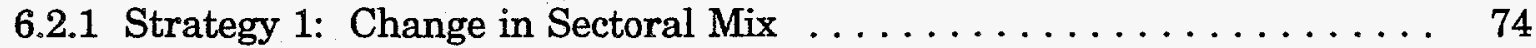

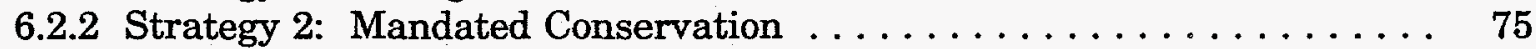

6.2.3 Strategy 3: Interfuel Substitution with Current Technology . . . . . . . 80

6.2.4 Strategy 4: Interfuel Substitution with Technological Advances . . . . 85

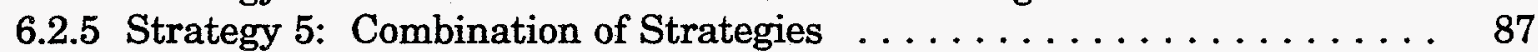

6.2 .6 Summary $\ldots \ldots \ldots \ldots \ldots \ldots \ldots \ldots \ldots \ldots \ldots \ldots \ldots \ldots$

6.3 Simulations for 2010 and 2025: Upper-Bound Case . . . . . . . . . . 87

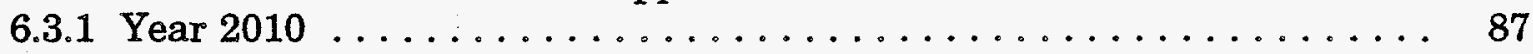

6.3 .2 Year $2025 \ldots \ldots \ldots \ldots \ldots \ldots \ldots \ldots \ldots \ldots \ldots \ldots \ldots \ldots$

6.4 Simulations for 2000, 2010, and 2025: Lower-Bound Case . . . . . . . . 94

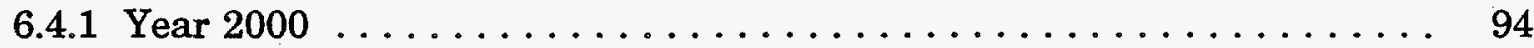

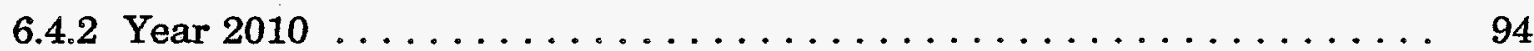

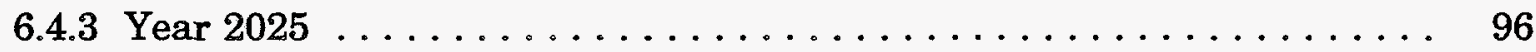

6.5 Investment Analysis . . . . . . . . . . . . . . . . . . . 100

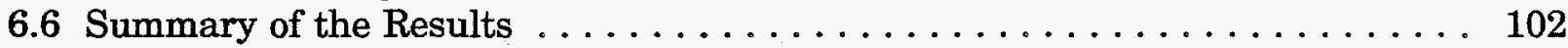

7 BIBLIOGRAPHY $\ldots \ldots \ldots \ldots \ldots \ldots \ldots \ldots \ldots \ldots \ldots \ldots \ldots \ldots \ldots$

APPENDIX A1: Upper-Bound Simulations . . . . . . . . . . . . . . . . 109

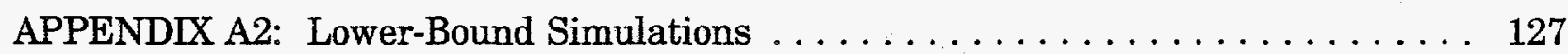

APPENDIX B: Investment Analysis Summary Tables $\ldots \ldots \ldots \ldots \ldots \ldots$

APPENDIX C1: Exploration/Production Investment Spreadsheets . . . . . . . . 153

APPENDIX C2: Generation/Transmission Investment Spreadsheets . . . . . . 165

\section{FIGURES}

S.1 Upper-Bound Case for China's Gross Domestic Product Projection . . . . . . . 5

S.2 Lower-Bound Case for China's Gross Domestic Product Projection . . . . . . . . 6

1 Schematic of the Major Components of an Input-Output Table . . . . . . . . 21

2 Projected $\mathrm{CO}_{2}$ Emissions for China $\ldots \ldots \ldots \ldots \ldots \ldots \ldots \ldots \ldots \ldots$ 


\section{FIGURES (Cont.)}

Micro Marginal Cost of Strategies

\section{TABLES}

1 Total Energy Production in China, $1980-1991 \ldots \ldots \ldots \ldots \ldots \ldots \ldots \ldots$

2 Total Energy Consumption in China, $1980-1991 \ldots \ldots \ldots \ldots \ldots \ldots \ldots$

3 Total Energy Consumption in China by Sector, 1985, 1989, and $1990 \ldots \ldots \ldots$. 11

4 Total Coal Consumption in China by Sector, 1985, 1989, and $1990 \ldots \ldots \ldots \ldots 13$

5 Total Crude Oil Consumption in China by Sector, 1985, 1989, and $1990 \ldots \ldots$. 14

6 Total Natural Gas Consumption in China by Sector, 1985, 1989, and $1990 \ldots \ldots$. . 15

7 Total Electricity Consumption in China by Sector, 1985, 1989, and $1990 \ldots \ldots$. . 16

8 Total Coke Consumption in China by Sector, 1985, 1989, and $1990 \ldots \ldots \ldots \ldots 17$

9 Composition of Total Supply and Demand in China, $1987 \ldots \ldots \ldots \ldots \ldots 23$

10 Percentage of Chinese Output Structure by Sector, $1987 \ldots \ldots \ldots \ldots \ldots 24$

11 Percentage of Material Consumption and Value Added

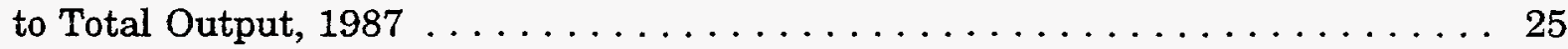

121990 Chinese Input-Output Table $\ldots \ldots \ldots \ldots \ldots \ldots \ldots \ldots \ldots \ldots \ldots \ldots$

13 China DLP Simulation Model Economic Parameters ................ 37

14 Baseline Projections - Upper Bound . . . . . . . . . . . . . . . . 41

15 Baseline Projections - Lower Bound $\ldots \ldots \ldots \ldots \ldots \ldots \ldots \ldots \ldots \ldots \ldots \ldots \ldots \ldots \ldots$

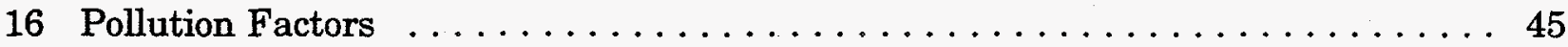

17 Direct Emissions from Use of Coal, $1990 \ldots \ldots \ldots \ldots \ldots \ldots \ldots \ldots$

18 Direct Emission Coefficients from Use of Coal, $1990 \ldots \ldots \ldots \ldots \ldots \ldots \ldots$

19 Direct Emissions from Use of Natural Gas, $1990 \ldots \ldots \ldots \ldots \ldots \ldots$ 


\section{TABLES (Cont.)}

20 Direct Emission Coefficients from Use of Natural Gas, $1990 \ldots \ldots \ldots \ldots \ldots$. . . . 47

21 Direct Emissions from Use of Petroleum Products, $1990 \ldots \ldots \ldots \ldots \ldots$. . . . 48

22 Direct Emissions Coefficients from Use of Petroleum Products, 1990 . . . . . . . 48

23 Direct Emissions from Use of All Fossil Fuels, $1990 \ldots \ldots$. . . . . . . . . . . . 49

24 Direct Emissions Coefficients from Use of All Fossil Fuels, $1990 \ldots \ldots$. . . . 49

25 Total Emission Coefficients from Use of All Fossil Fuels, $1990 \ldots \ldots \ldots \ldots \ldots$. . . . 51

26 Energy Consumption in China, $1990 \ldots \ldots \ldots \ldots \ldots \ldots \ldots \ldots \ldots \ldots \ldots \ldots \ldots \ldots$

27 China's Proven Reserves at the End of $1992 \ldots \ldots \ldots \ldots \ldots \ldots \ldots \ldots \ldots$

28 Natural Gas Reserve Calculations for China .................. 55

29 Constraints for Natural Gas Used in the DLP Simulation $\ldots \ldots \ldots \ldots \ldots \ldots 5$

30 Fuel Mix in Electricity Generation in China, $1990 \ldots \ldots \ldots \ldots \ldots$

31 Data Status for Renewable Fuels and Technologies in China . . . . . . . . 58

32 Potential for Clean Fuels in Electricity Generation:

Upper-Bound Parameters . . . . . . . . . . . . . . . . . . 62

33 Technological Change in Energy Use: Upper-Bound Parameters . . . . . . . . 64

34 Potential for Clean Fuels in Electricity Generation:

Lower-Bound Parameters . . . . . . . . . . . . . . . . . . 67

35 Technological Change in Energy Use: Lower-Bound Parameters . . . . . . . . 68

36 Carbon Emission Reduction Strategy Simulations $\ldots \ldots \ldots \ldots \ldots \ldots \ldots$

37 China's DLP Simulation Model Economic Parameters ............. 72

$38 \mathrm{CO}_{2}$ Reduction Requirements and Compliance Schedule $\ldots \ldots \ldots \ldots \ldots \ldots$

39 Simulation Results: China DLP Model $1-U \ldots \ldots \ldots \ldots \ldots \ldots \ldots$

40 Simulation Results: China DLP Model 2-U, with Constraint $\ldots \ldots \ldots \ldots \ldots 78$

41 Simulation Results: China DLP Model 2-U, without Constraint . . . . . . . . 79 


\section{TABLES (Cont.)}

42 Potential for Clean Fuels in Electricity Generation:

Upper-Bound Parameters . . . . . . . . . . . . . . . . . . 81

43 Percentage of Electricity Sector Fuel Mix: Upper-Bound Values . . . . . . . . 81

44 Simulation Results: China DLP Model $3-U \ldots \ldots \ldots \ldots \ldots \ldots$

45 Simulation Results: China DLP Model 3-U, with Constraint . . . . . . . . 84

46 Percentage of Technological Change in Energy Use:

Upper-Bound Parameters . . . . . . . . . . . . . . . . . . . 85

47 Simulation Results: China DLP Model 4-U, with Constraint . . . . . . . . . 86

48 Simulation Results: China DLP Model 3-U, with Constraint $\ldots \ldots \ldots \ldots \ldots 8$

49 Summary of Simulation Results, Year 2000: Upper-Bound Case . . . . . . . . 89

50 Summary of Simulation Results, Year 2010: Upper-Bound Case . . . . . . . 90

51 Summary of Simulation Results, Year 2025: Upper-Bound Case . . . . . . . 93

52 Potential for Clean Fuels in Electricity Generation:

Lower-Bound Parameters . . . . . . . . . . . . . . . . . . . . 95

53 Percentage of Electricity Sector Fuel Mix: Lower-Bound Values . . . . . . . . 95

54 Percentage of Technological Change in Energy Use:

Lower-Bound Parameters . . . . . . . . . . . . . . . . . . 96

55 Summary of Simulation Results, Year 2000: Lower-Bound Case . . . . . . . . 97

56 Summary of Simulation Results, Year 2010: Lower-Bound Case . . . . . . . 98

57 Summary of Simulation Results, Year 2025: Lower-Bound Case . . . . . . . 99

58 Gross Investment for $\mathrm{CO}_{2}$ Mitigation: Interfuel Substitution and Technological Change Strategies 


\title{
NOTATION
}

The following is a list of the acronyms, initialisms, and abbreviations (including

chemical symbols and units of measurement) used in this document.

\section{ACRONYMS, INITIALISMS, AND ABBREVIATIONS}

\author{
ADB Asian Development Bank \\ AEEI autonomous energy efficiency improvement \\ ANL Argonne National Laboratory \\ DLP Dynamic Linear Programming \\ EWC East-West Center \\ GDP gross domestic product \\ GHG greenhouse gas \\ GNP gross national product \\ I-O input-output \\ LP linear programming \\ MPS material production system \\ PV photovoltaic \\ $\mathrm{R} / \mathrm{P}$ reserves-to-production \\ SNA system of national accounts
}

\section{CHEMICAL SYMBOLS AND ABBREVIATIONS}

$\begin{array}{ll}\mathrm{CFC} & \text { chorofluorocarbon } \\ \mathrm{CH}_{4} & \text { methane } \\ \mathrm{CO}_{2} & \text { carbon dioxide } \\ \mathrm{SO}_{2} & \text { sulfur dioxide }\end{array}$

\section{UNITS OF MEASUREMENT}

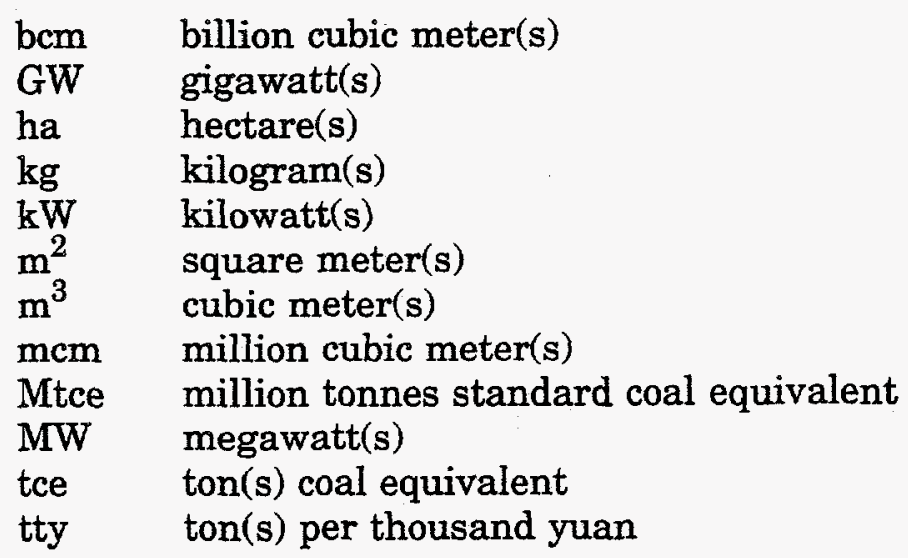


tcm trillion cubic meter(s)

tonne metric ton(s)

TWh terawatt hour(s)

W watt(s)

yr year(s) 



\title{
COAL USE IN THE PEOPLE'S REPUBLIC OF CHINA, VOLUME 2: THE ECONOMIC EFFECTS OF CONSTRAINING COAL UTILIZATION
}

\author{
A. Rose, M.M. Tompkins, D. Lim, O. Frias, and J. Benavides
}

\begin{abstract}
The People's Republic of China (hereafter referred to as China) is the largest producer and consumer of coal in the world. The dominance of coal in China's energy balance has come at a high price to the environment. With the recent attention given to global warming issues, China's energy consumption and production practices have become the subject of much concern. Of particular concern is China's ability to reduce $\mathrm{CO}_{2}$ emissions by constraining coal use and the impact such policies will likely have on the Chinese economy. The study is divided into two reports. Volume 1 focuses on the full coal fuel cycle, emissions, and environmental effects. This report (Volume 2) analyzes various $\mathrm{CO}_{2}$ mitigation strategies and determines their effect on economic growth. Contrary to what some analysts have claimed, the current work suggests that it would not be costly for the Chinese to reduce $\mathrm{CO}_{2}$ emissions. In fact, some strategies were accompanied by increases in China's energy and economic efficiency, which actually stimulated economic growth.
\end{abstract}

\section{SUMMARY}

Global warming could prove catastrophic for most nations. Pressure is mounting among nations to reduce the causes of global warming, especially the emission of greenhouse gases (GHGs) from fossil fuel combustion. A global problem of this magnitude requires a global solution; therefore, the cooperation among energy-intensive economies - industrialized or developing nations - is crucial.

The People's Republic of China (hereafter referred to as China) is an obvious candidate to take the lead in reducing GHG emissions because it is the world's largest producer and consumer of coal. However, with a per capita income of less than $\$ 400$, China is also one of the world's 25 poorest countries. Some analysts have suggested that it will be very costly to curb GHG emissions. Thus, the question arises as to the equity, if not the feasibility, of having China initiate major mitigation measures. Other analysts have suggested that efforts to cope with global warming present various opportunities to simultaneously improve energy and economic efficiency. 
This report analyzes how GHG mitigation policies would affect the growth of China's economy over the next 30 years. The focus is on reducing coal use and examining the implications for reducing carbon dioxide $\left(\mathrm{CO}_{2}\right)$. Implications for other fossil fuels, renewable energy resources, and other air pollutants are also examined, specifically the partial and general equilibrium economic impacts of achieving a 20\% reduction in year 2000 baseline $\mathrm{CO}_{2}$ emissions by 2025 . Given the tenor of ongoing negotiations, a phased-in compliance schedule seems appropriate for this target year. The present analysis divides the compliance period into three periods: $1990-2000,2000-2010$, and 2010-2025.

This report discusses the modifications of the official Chinese Input-Output (I-O) Table, which is the major source of sectoral and macroeconomic data used in this analysis. An I-O model is an operational, static, linear model of all purchases and sales among sectors of the economy, based on the technical relations of production. This I-O table is the most widely used tool in analyzing economic impacts and is used either alone in a mathematical programming format or as the basis of computable general equilibrium models. This report uses a 33-sector aggregation of the 1987 I-O table and updates it to the 1990 base year. The same model structure is used for baseline projections over the planning horizon; however, for policy simulations, key economic, energy, and environmental coefficients were changed.

The Dynamic Linear Programming (DLP) model is summarized equation by equation. This model format is most appropriate for a centrally planned economy. It represents an extension of I-O to an explicit optimization capability subject to various constraints that relate to labor, capital, and energy resources, plus limits on air pollution emissions. The DLP model is further extended to a consistent forecasting version that can incorporate basic assumptions that relate to growth rates in gross domestic product (GDP), population, wages, and investments.

Baseline projections for China's economy are given for the three policy periods. Basic economic parameters make a significant difference over a 35-year period. Therefore, these parameters are grouped into two major categories, and separate simulations are run for each. Category 1 - a group of "optimistic" (higher numerical value) parameters - is referred to as upper bound, and Category 2 - a group of "pessimistic" (lower numerical value) parameters - is referred to as lower bound. For example, the upper-bound economic growth assumptions lead to a GDP projection of 24,934 billion yuans in the year 2025, while the lower-bound economic growth assumptions lead to a projection of 8,591 billion yuans in that year.

Environmental pollution, energy reserves, and energy technologies are analyzed, and the emission factors for fossil fuels developed by Argonne National Laboratory (ANL) staff are adapted for the present model. The literature on reserve estimates is examined for fuel availability and electricity-generating capacity for clean alternatives (e.g., hydro, nuclear, and natural gas). This report assumes that these alternatives can reduce $\mathrm{CO}_{2}$ emissions by more than $90 \%$ of baseline year 2025 emissions in the upper-bound (optimistic) case and by about $28 \%$ in the lower-bound (pessimistic) case. Major technological considerations such as the electricity/GDP ratio, the displacement of coal in industrial boilers, and autonomous 
Five strategies to reduce $\mathrm{CO}_{2}$ emissions are analyzed:

- Change in the sectoral mix,

- Mandated conservation,

- Interfuel substitution with current technology,

- Interfuel substitution with technological advances, and

- Combination of strategies.

The impacts on final demand (GDP), gross output, $\mathrm{CO}_{2}$, and sulfur dioxide $\left(\mathrm{SO}_{2}\right)$ are simulated in the aggregate. Detailed impacts for different sectors are presented for each of these indicators. Investment considerations associated with various strategies are analyzed.

The major findings of the study are:

- To meet the 5\% target $\mathrm{CO}_{2}$ reduction for the year 2000, China has several options that do not adversely affect its development plans. Moreover, strategies that conserve and displace coal in industrial uses may actually boost economic growth slightly above baseline projections. It appears that actions taken to mitigate $\mathrm{CO}_{2}$ emissions also reduce emissions of other major air pollutants, such as $\mathrm{SO}_{2}$, by about the same amount.

- By 2010, the effective abatement requirement changes for the upperand lower-bound cases to $57.30 \%$ and $40.50 \%$, respectively, of that year's baseline emissions. This more stringent requirement makes most single strategies infeasible, i.e., incapable of achieving the desired emission reduction target on their own. Combining strategies can meet the target, with only a slight decrease in the baseline gross national product growth rate in the lower-bound case and no decrease in the upper-bound case.

- By 2025, fewer options are available for achieving $84.91 \%$ and $65.31 \%$ of that year's baseline $\mathrm{CO}_{2}$ emissions. Changing the sectoral mix cannot achieve the results, and autonomous conservation can only achieve reductions of about one-half of the upper-bound target and two-thirds of the lower-bound one, and only at large penalties. However, combining interfuel substitution and technological change could attain the targeted reduction of $\mathrm{CO}_{2}$ emissions in the upper-bound case, with little economic penalty. Still, the result highly depends on the assumption of total displacement of coal in industry and very substantial shifts to nuclear, hydro, and gas-fired electricity generation. Otherwise, China's economic growth could decrease to $1.0-3.0 \%$ below baseline. For the lower-bound case, a mix of interfuel substitution, technological change, and sectoral 
hydro, and gas-fired electricity generation. Otherwise, China's economic growth could decrease to 1.0-3.0\% below baseline. For the lower-bound case, a mix of interfuel substitution, technological change, and sectoral mix changes can achieve the target, but at a sizable penalty that would reduce economic growth from 3 to $0.85 \%$.

- For 2000 and 2010, results differ only slightly between upper- and lower-bound cases, suggesting that they are robust over a broad range of assumptions relating to China's economy, energy reserves, and energy technologies.

- Although investment costs associated with these strategies may appear to be exorbitant, they are not. Projections show that China will need significantly more electricity-generating capacity under the baseline scenario. Most of these strategies do not significantly increase the demand for electricity; in fact, most call for decreases. Moreover, sufficient lead time is available to switch to cleaner fuels, while building new plants rather than retrofitting old ones. Finally, these strategies call for a decrease in exploration and extraction costs, especially for hydro and nuclear options.

- Unless the $\mathrm{CO}_{2}$ reduction measures enacted in China are "sustainable" (i.e., become part of China's economy and energy system), it could be costly to meet the reduction requirements in 2025 and beyond, under either the upper- or the lower-bound scenario. Achieving this goal may involve restructuring the economy and implementing conservation measures that are no longer costless. In fact, without discovering major resources or developing technological innovations (in addition to those projected in this report), $\mathrm{CO}_{2}$ reduction targets beyond 2025 may not be feasible. Moreover, these targets may not be feasible for 2025 if some of the lower-bound assumptions are too optimistic.

Figures S.1 and S.2 present results for the baseline case, Strategy 1 (change in the sectoral mix), and Strategy 5 (combination of strategies). For the upper-bound cases, Strategy 1 achieves the 5\% emission reduction in 2000 without penalty, but economic growth significantly decreases by 2010 . Moreover, this option is not feasible by 2025 (i.e., the target $\mathrm{CO}_{2}$ reductions cannot be attained). However, this outcome is not a major concern because several strategies can be combined to reduce emissions in all target years.

One combination of strategies can boost economic growth (from 6.50 to $6.51 \%$ ), mainly as a result of cost savings plus the right combination of general equilibrium effects. For lower-bound cases, Strategy 1 imposes a slight penalty in 2010 , but this strategy would lead to a major downturn in the economy in 2025 . In this case, a combination of strategies would not impose any penalty in 2010 but would significantly reduce the rate of economic growth from 3 to $0.85 \%$ in 2025 . 


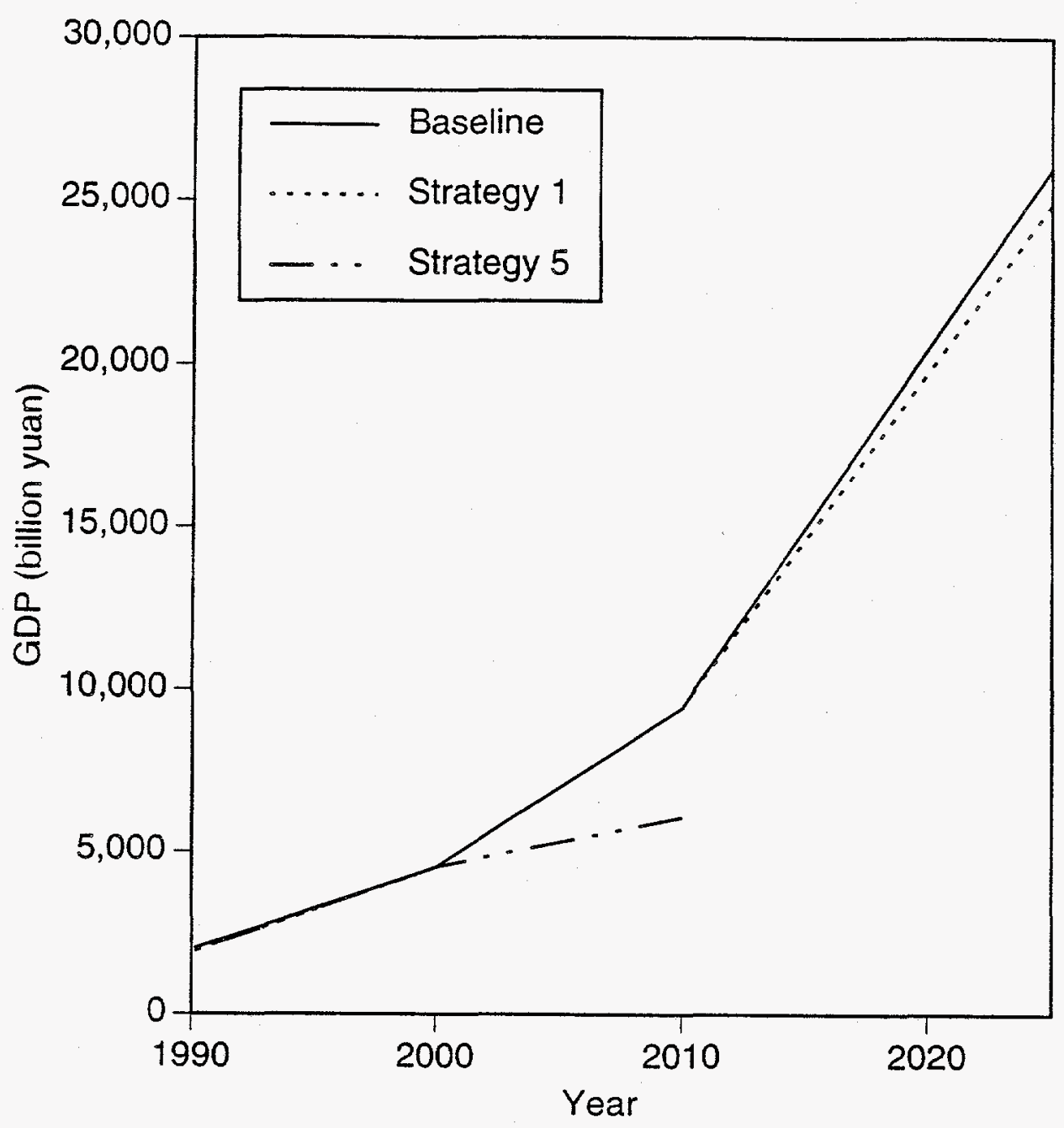

FIGURE S.1 Upper-Bound Case for China's Gross Domestic Product Projection 


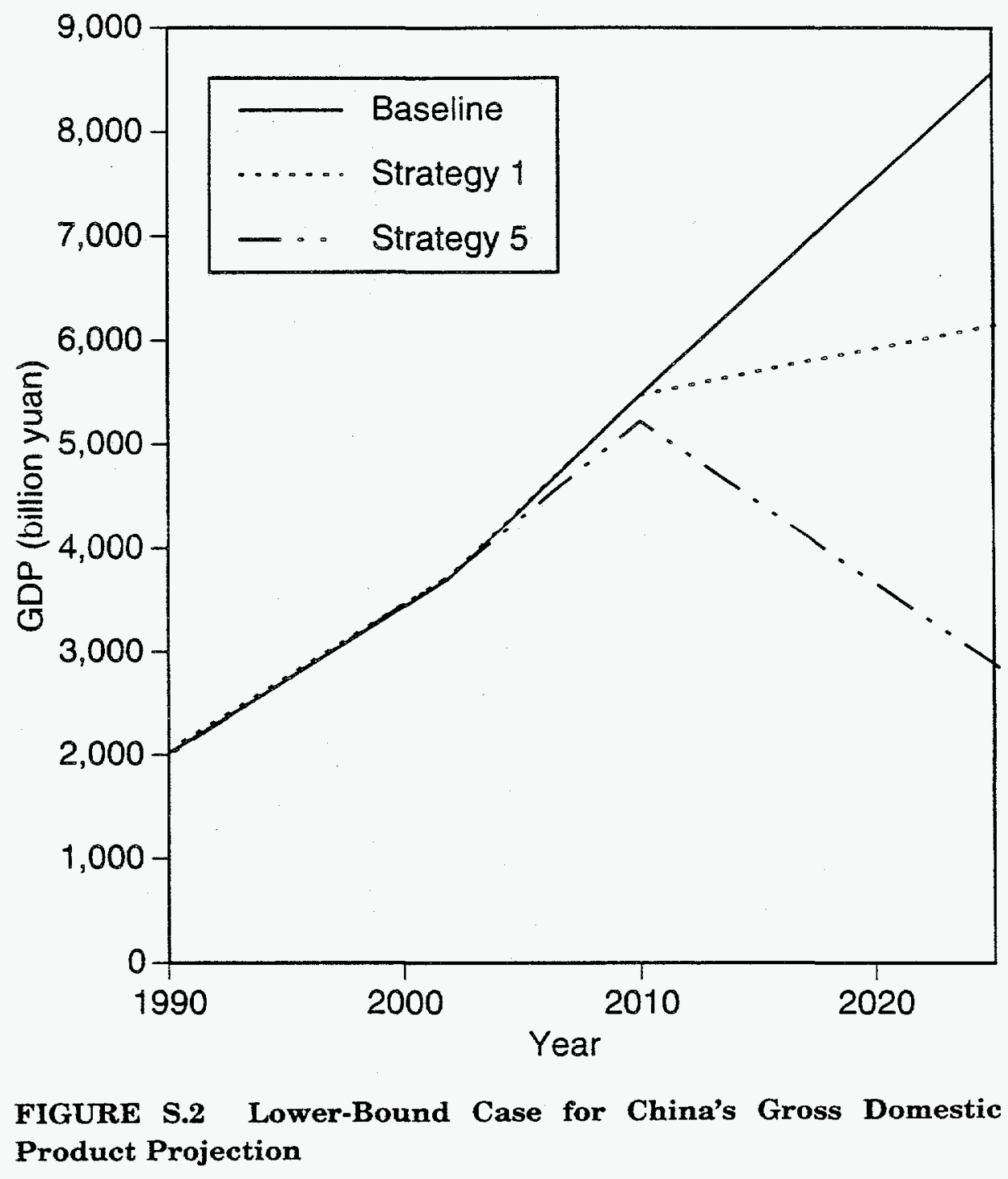




\section{INTRODUCTION}

The potential for global climate change is growing, as is the awareness of the seriousness of the problem (Intergovernmental Panel on Climate Change 1992). The emission of gases (e.g., carbon dioxide $\left[\mathrm{CO}_{2}\right]$, methane $\left[\mathrm{CH}_{4}\right]$, and chlorofluorocarbons [CFCs]) that accentuate the greenhouse effect is a major contributor. Greenhouse gases (GHGs) build up in the earth's atmosphere and trap sunlight that is usually reflected back into space from the earth's surface. The situation is global. First, every country generates GHGs. However, industrialized nations generate GHGs primarily from fossil fuel combustion, whereas developing nations emit these gases from agriculture and forest clearings. Second, these gases mix in the atmosphere, so that emissions in one location contribute to the problem worldwide.

A global problem of this magnitude requires a global solution. Natural scientists, social scientists, and policymakers have discussed the need for measures that would curtail GHG emissions (Task Force on the Comprehensive Approach to Climate Change 1991; Barrett et al. 1992). Many nations have called for an international GHG treaty, or protocol. This protocol, for example, could be patterned somewhat after the Montreal Accord, which limited the emissions of CFCs that cause holes in the ozone layer (Organization for Economic Cooperation and Development 1992).

However, scientific evidence that affirms the acceleration of greenhouse warming is not unequivocal, and mitigating GHGs is considered costly (Cline 1992; Lindzen 1992). Many nations resist making firm commitments that would lead to an accord. Moreover, no supranational institution exists that has the authority to enforce an agreement.

The result is tension among nations, especially the industrialized countries of the "North" and the developing countries of the "South." The North is alarmed at the pace at which GHG emissions are projected to rise in the South as economic development progresses. The South points out that GHGs are stock pollutants (i.e., they build up and are retained in the atmosphere, in many cases for decades) and notes that most of the radiative forcing caused by GHGs is the responsibility of the North's more than 100 years of industrialization (Agarwal and Narain 1991). Moreover, the developing countries state that any diversion of resources to mitigate GHGs would stifle future development. They consider it hypocrisy for the North to have been able to industrialize without such a commitment, but now call for the South to do so. Many developing countries emphasize their limitations in complying with an accord that calls for major reductions in GHGs. At the same time, many suggestions have been made to overcome this problem: (1) lower mitigation requirements for developing countries, (2) transfer technology, (3) redistribute proceeds of carbon tax, or (4) grant developing countries a large portion of emissions permits (Grubb and Sebenius 1991; Rose and Stevens 1993).

The costs of mitigating GHGs extend beyond the direct, or more obvious, expenditures for retrofitting boilers to burn cleaner fuels, constructing nuclear hydropower plants, restructuring the economy in favor of less energy-intensive goods, or installing $\mathrm{CO}_{2}$ 
scrubbers. Given the interdependence of any economy, these direct expenditures stimulate important second-order, or general equilibrium, effects. These effects include ordinary price and output multipliers, input substitutions, endogenous technological changes, and investment crowding. If an economy allocates its resources optimally, any reallocation will move it away from this optimal state, thereby lowering the gross domestic product (GDP) and other major indicators of well-being.

However, several analysts state that no economy is at its optimum. In fact, strong evidence shows that many economies are wasteful of their resources, especially their energy resources (National Academy of Sciences 1991; Office of Technology Assessment 1991; Cline 1992; Ayres 1994). Numerous ways are available for implementing energy conservation measures in either a cost-saving or costless manner in both industrialized and developing countries. Also, most analysts suggest that developing countries can mitigate GHGs more readily than can industrialized nations.

This report analyzes the impacts of GHG mitigation policies on the future growth of the People's Republic of China's (hereafter referred to as China) economy over the next 30 years. The focus is primarily on reducing coal use and on examining the implications of reducing $\mathrm{CO}_{2}$. The implications for other fossil fuels, renewable energy resources, other GHGs, and "ordinary" air pollutants are also examined.

The analysis uses a multisector Dynamic Linear Programming (DLP) model especially designed for this project. The core of the model is a 33-sector input-output (I-O) table of China's economy adapted to an optimization framework (Chenery and Clark 1959; Almon 1963; Dervis et al. 1982).

This situation is very poignant for a country like China. With a per capita GDP of about $\$ 400$, China ranks among the world's 25 poorest countries. At the same time, China is a major energy user and a significant contributor to GHG emissions. The combination of its high-energy/GDP ratio for a country at its level of development and an extrapolation of its high growth rate means that China could become a leading emitter of $\mathrm{CO}_{2}$ in 30 years. Should China decrease GHG emissions by reducing energy consumption, especially of its abundant, low-cost coal reserves? Will this strategy have a strong, negative impact on its future economic development? Highlighting the urgency of the matter is the fact that the global warming problem is a zero-sum game. Each country that does not control one ton of $\mathrm{CO}_{2}$ shifts the burden to other countries. At the same time, the public good of GHG abatement means that any country can take a "free ride" on the mitigation of others. 


\section{ENERGY IN CHINA}

The structural and institutional changes and reforms that have occurred since the 1980s are reshaping China's economy. Under the Eighth Five-Year Plan (1991-1996), China is continuing to implement reforms, to open to the outside world, and to increase production and income. Present goals include increased economic efficiency, decreased energy intensity in industry, and increased production of intermediate and final manufactured goods for trade.

China is the world's largest coal producer and consumer, the sixth largest oil producer, and the fifth largest oil consumer. China's total energy production, in terms of million tonnes standard coal equivalent (Mtce), increased 4.6\% per year from 1980 to 1991 . Coal and hydropower increased, but crude oil and natural gas decreased as components of energy production (Table 1). Total energy consumption, in terms of Mtce, increased $4.9 \%$ per year over the same period. In 1991, coal accounted for $76 \%$ of total energy consumption; oil, 17.0\%; natural gas, 2.0\%; and hydropower, 5.0\% (Table 2).

From 1980 to 1991, China's GDP increased more than $10 \%$ per year, while energy consumption grew 4.9\%. Energy intensity fell from 2.14 to 1.42 Mtce per $\$ 1,000$ of GDP (1980 prices). The downward trend in energy intensity is attributable to (1) economic reform and growth during the last decade; (2) energy conservation policies initiated in the 1980s, which were supported by increases in energy prices; and (3) replacement of inefficient plants.

\subsection{ENERGY STRUCTURE}

Coal is China's most important energy source for production and consumption. China's coal consumption reached 751.1 Mtce, accounting for $76.2 \%$ of total energy consumption in 1990. However, the widespread use of coal has increased environmental pollution.

Since the mid-1980s, the composition of China's total energy consumption has been relatively stable. On the basis of 1990 data, industry accounted for the major proportion of energy consumption in China. Compared with developed countries, the level of energy use in China's households was low, especially for high-grade energy sources. Household energy consumption accounted for $16.0 \%$ of the total. In 1990, transportation and commercial consumption were about $4.6 \%$ and $4.8 \%$, respectively. The chemical industry is the largest user of energy, followed by ferrous metals, building materials, and mining. The chemical industry accounted for $11.1 \%$ of total energy consumption in 1990 (Table 3).

China's economic structure is based heavily on its domestic supply of energy. Energy imports and exports make up a small portion of the total energy supply and demand. In 1990, China exported 58.8 Mtce, which represented about 6\% of the world's energy consumption. Because China does not need to import energy on a large scale, the structure of primary energy consumption is basically the same as that of production. 
TABLE 1 Total Energy Production in China, 1980-1991

\begin{tabular}{cccccc}
\hline & & \multicolumn{4}{c}{ Percentage of Total Production } \\
\cline { 3 - 6 } Year & Total $^{2}$ & Coal & $\begin{array}{c}\text { Crude } \\
\text { Oil }\end{array}$ & $\begin{array}{c}\text { Natural } \\
\text { Gas }\end{array}$ & $\begin{array}{c}\text { Hydro- } \\
\text { power }\end{array}$ \\
\hline 1980 & 637.35 & 69.4 & 23.8 & 3.0 & 3.8 \\
1985 & 855.46 & 72.8 & 20.9 & 2.0 & 4.3 \\
1988 & 958.01 & 73.1 & 20.4 & 2.0 & 4.5 \\
& & & & & \\
1989 & $1,016.40$ & 74.1 & 19.3 & 2.0 & 4.6 \\
1990 & $1,039.20$ & 74.2 & 19.0 & 2.0 & 4.8 \\
1991 & $1,048.40$ & 74.1 & 19.2 & 2.0 & 4.7 \\
\hline
\end{tabular}

a Million tonnes standard coal equivalent.

Source: China Statistical Yearbook (1992).

TABLE 2 Total Energy Consumption in China, 1980-1991

\begin{tabular}{rrrrrr}
\hline & & \multicolumn{4}{c}{ Percentage of Total Production } \\
\cline { 3 - 6 } Year & Total $^{\mathrm{a}}$ & Coal & $\begin{array}{c}\text { Crude } \\
\text { Oil }\end{array}$ & $\begin{array}{c}\text { Natural } \\
\text { Gas }\end{array}$ & $\begin{array}{c}\text { Hydro- } \\
\text { power }\end{array}$ \\
\hline \multirow{2}{*}{1980} & 602.75 & 72.2 & 20.7 & 3.1 & 4.0 \\
1985 & 766.82 & 75.8 & 17.1 & 2.2 & 4.9 \\
1988 & 929.97 & 76.2 & 17.0 & 2.1 & 4.7 \\
& & & & & \\
1989 & 969.34 & 76.0 & 17.1 & 2.0 & 4.9 \\
1990 & 987.03 & 76.2 & 16.6 & 2.1 & 5.1 \\
1991 & $1,023.00$ & 76.0 & 17.0 & 2.0 & 5.0 \\
\hline
\end{tabular}

a Million tonnes standard coal equivalent.

Source: China Statistical Yearbook (1992). 
TABLE 3 Total Energy Consumption in China by Sector, 1985, 1989, and $1990^{\mathrm{a}}$

\begin{tabular}{|c|c|c|c|c|c|c|}
\hline \multirow[b]{2}{*}{ Sector } & \multicolumn{2}{|c|}{1985} & \multicolumn{2}{|c|}{1989} & \multicolumn{2}{|c|}{1990} \\
\hline & $\begin{array}{l}\text { Consumption } \\
\text { (Mtce) }\end{array}$ & $\begin{array}{c}\text { Composition } \\
(\%)\end{array}$ & $\begin{array}{c}\text { Consumption } \\
\text { (Mtce) }\end{array}$ & $\begin{array}{c}\text { Composition } \\
(\%)\end{array}$ & $\begin{array}{l}\text { Consumption } \\
\text { (Mtce) }\end{array}$ & $\begin{array}{c}\text { Composition } \\
(\%)\end{array}$ \\
\hline Agriculture & 40.45 & 5.3 & 47.42 & 4.9 & 48.52 & 4.9 \\
\hline Manufacturing & 510.68 & 66.6 & 662.91 & 68.4 & 675.78 & 68.5 \\
\hline Mining & 57.52 & 7.5 & 73.51 & 7.6 & 77.78 & 7.9 \\
\hline Food & 23.94 & 3.1 & 32.81 & 3.4 & 32.79 & 3.3 \\
\hline Textiles & 23.81 & 3.1 & 30.15 & 3.1 & 30.34 & 3.1 \\
\hline Paper & 12.95 & 1.7 & 16.97 & 1.8 & 16.94 & 1.7 \\
\hline Power generation & 25.12 & 3.3 & 36.57 & 3.8 & 38.67 & 3.9 \\
\hline Petroleum & 10.08 & 1.3 & 16.10 & 1.7 & 17.06 & 1.7 \\
\hline $\begin{array}{c}\text { Coking, gas, } \\
\text { and coal }\end{array}$ & 6.44 & 0.8 & 8.70 & 0.9 & 8.02 & 0.8 \\
\hline Chemicals & 80.99 & 10.6 & 109.46 & 11.3 & 109.86 & 11.1 \\
\hline Medical & 4.44 & 0.6 & 6.46 & 0.7 & 6.53 & 0.7 \\
\hline Chemical fibers & 5.15 & 0.7 & 7.29 & 0.8 & 7.49 & 0.8 \\
\hline Building materials & 80.20 & 10.5 & 102.06 & 10.5 & 97.22 & 9.8 \\
\hline Ferrous metal & 76.40 & 10.0 & 99.80 & 10.3 & 105.55 & 10.7 \\
\hline $\begin{array}{l}\text { Nonferrous } \\
\text { metal }\end{array}$ & 13.71 & 1.8 & 17.97 & 1.9 & 18.91 & 1.9 \\
\hline $\begin{array}{c}\text { Machine and } \\
\text { electricity }\end{array}$ & 41.57 & 5.4 & 45.75 & 4.7 & 45.23 & 4.6 \\
\hline Other products & 48.36 & 6.2 & 59.31 & 5.9 & 63.39 & 6.5 \\
\hline Construction & 13.02 & 1.7 & 12.71 & 1.3 & 12.13 & 1.2 \\
\hline Transportation & 37.13 & 4.8 & 44.99 & 4.6 & 45.41 & 4.6 \\
\hline Commerce & 7.66 & 1.0 & 12.09 & 1.2 & 12.47 & 1.3 \\
\hline $\begin{array}{c}\text { Nonmaterial } \\
\text { products }\end{array}$ & 24.70 & 3.2 & 33.39 & 3.4 & 34.73 & 3.5 \\
\hline Households & 133.18 & 17.4 & 155.83 & 16.1 & 158.00 & 16.0 \\
\hline Total consumption & 766.82 & 100.0 & 969.34 & 100.0 & 987.03 & 100.0 \\
\hline
\end{tabular}

a Values may not add because of rounding.

Source: China Statistical Yearbook (1992). 
The sectoral consumption of major fuels, including coke, is presented in Tables 4 through 8. A more detailed description of China's energy picture can be found in Bhatti et al. (1994).

\subsection{ENERGY STRATEGY}

Because of China's centrally planned economy, energy production is influenced significantly by economic policies and political climate. In the past, this concept resulted in inefficient use of energy. However, the Chinese government is now implementing policies that improve economic efficiency and maintain high economic growth. Now that economic reform has begun, energy development has become an important strategy.

Several measures can achieve these policy targets. Because of China's high economic growth and progress in modernization, it will need to generate substantially more electric power in the future. China plans to diversify its energy structure and, thereby, reinforce the exploration and exploitation of oil and natural gas. It also plans to develop hydropower and nuclear power.

Current levels of funds, equipment, and technology are insufficient to increase energy production. China plans to invest more in energy programs to balance energy production and consumption. In addition, the nation will encourage foreign countries to invest in energy. This plan will efficiently raise funds for energy development.

Despite diversification in energy structure, China's current official position is to continue to rely on coal as its main energy source. Inefficient transportation capacity has become the most important obstacle to the effective use of coal, and thus further development of the coal industry will highly depend on improving the transportation system. However, current plans do not include a significant commitment to reduce GHGs. This study identifies ways in which China's energy strategy may have to change, if the nation is to enter an international accord to avert global warming.

\subsection{REPORT ORGANIZATION}

This report is organized into four major parts. Section 3 presents the I-O table that serves as the major economic database. A discussion of the contents of the table provides the reader with important insights into the structure of China's economy.

Section 4 presents the DLP model used in this analysis. The model combines features of optimization and consistent forecasting model frameworks, which are ideally suited to analyzing one of the world's few remaining centrally planned economies. Baseline projections for target years 2000,2010 , and 2025 are presented in terms of sets of upper- and lower-bound economic and demographic parameters, which enables subsequent sensitivity analyses. 
TABLE 4 Total Coal Consumption in China by Sector, 1985, 1989, and $1990^{\mathrm{a}}$

\begin{tabular}{|c|c|c|c|c|c|c|}
\hline \multirow[b]{2}{*}{ Sector } & \multicolumn{2}{|c|}{1985} & \multicolumn{2}{|c|}{1989} & \multicolumn{2}{|c|}{1990} \\
\hline & $\begin{array}{l}\text { Consumption } \\
\text { (Mtce) }\end{array}$ & $\begin{array}{c}\text { Composition } \\
(\%)\end{array}$ & $\begin{array}{l}\text { Consumption } \\
\text { (Mtce) }\end{array}$ & $\begin{array}{c}\text { Composition } \\
(\%)\end{array}$ & $\begin{array}{l}\text { Consumption } \\
\text { (Mtce) }\end{array}$ & $\begin{array}{c}\text { Composition } \\
(\%)\end{array}$ \\
\hline Agriculture & 22.09 & 2.7 & 21.81 & 2.1 & 20.95 & 2.0 \\
\hline Manufacturing & 586.13 & 71.8 & 785.65 & 76.0 & 810.91 & 76.8 \\
\hline Mining & 63.16 & 7.7 & 81.29 & 7.9 & 88.22 & 8.4 \\
\hline Food & 24.49 & 3.0 & 33.21 & 3.2 & 33.25 & 3.2 \\
\hline Textiles & 18.68 & 2.3 & 23.70 & 2.3 & 23.59 & 2.2 \\
\hline Paper & 12.51 & 1.5 & 16.44 & 1.6 & 16.40 & 1.6 \\
\hline Power generation & 166.19 & 20.4 & 249.04 & 24.1 & 270.59 & 25.6 \\
\hline Petroleum & 0.44 & 0.1 & 2.49 & 0.2 & 2.98 & 0.3 \\
\hline $\begin{array}{l}\text { Coking, gas, } \\
\text { and coal }\end{array}$ & 32.15 & 3.9 & 45.49 & 4.4 & 45.04 & 4.3 \\
\hline Chemicals & 51.90 & 6.4 & 73.93 & 7.1 & 72.41 & 6.9 \\
\hline Medical & 3.70 & 0.5 & 5.52 & 0.5 & 5.48 & 0.5 \\
\hline Chemical fibers & 3.15 & 0.4 & 4.38 & 0.4 & 4.48 & 0.4 \\
\hline Building materials & 86.14 & 10.6 & 106.70 & 10.3 & 99.60 & 9.4 \\
\hline Ferrous metal & 65.48 & 8.0 & 77.93 & 7.5 & 80.90 & 7.7 \\
\hline $\begin{array}{l}\text { Nonferrous } \\
\text { metal }\end{array}$ & 6.41 & 0.8 & 7.56 & 0.7 & 8.15 & 0.8 \\
\hline $\begin{array}{l}\text { Machine and } \\
\text { electricity }\end{array}$ & 27.48 & 3.4 & 30.39 & 2.9 & 29.33 & 2.8 \\
\hline Other products & 24.25 & 2.8 & 27.58 & 2.9 & 30.46 & 2.7 \\
\hline Construction & 5.32 & 0.7 & 4.53 & 0.4 & 4.38 & 0.4 \\
\hline Transportation & 23.07 & 2.8 & 22.84 & 2.2 & 21.61 & 2.0 \\
\hline Commerce & 7.38 & 0.9 & 10.24 & 1.0 & 10.58 & 1.0 \\
\hline $\begin{array}{c}\text { Nonmaterial } \\
\text { products }\end{array}$ & 15.08 & 1.9 & 18.78 & 1.8 & 19.80 & 1.9 \\
\hline Households & 133.18 & 17.4 & 155.83 & 16.1 & 158.00 & 16.0 \\
\hline Total consumption & 814.20 & 100.0 & $1,034.27$ & 100.0 & $1,055.23$ & 100.0 \\
\hline
\end{tabular}

${ }^{a}$ Values may not add because of rounding.

Source: China Statistical Yearbook (1992). 
TABLE 5 Total Crude Oil Consumption in China by Sector, 1985, 1989, and $1990^{\mathrm{R}}$

\begin{tabular}{|c|c|c|c|c|c|c|}
\hline \multirow[b]{2}{*}{ Sector } & \multicolumn{2}{|c|}{1985} & \multicolumn{2}{|c|}{1989} & \multicolumn{2}{|c|}{1990} \\
\hline & $\begin{array}{c}\text { Consumption } \\
\text { (1,000 tons) }\end{array}$ & $\begin{array}{c}\text { Composition } \\
(\%)\end{array}$ & $\begin{array}{c}\text { Consumption } \\
\text { (1,000 tons) }\end{array}$ & $\begin{array}{c}\text { Composition } \\
(\%)\end{array}$ & $\begin{array}{c}\text { Consumption } \\
\text { (1,000 tons) }\end{array}$ & $\begin{array}{c}\text { Composition } \\
(\%)\end{array}$ \\
\hline Agriculture & 8 & 0.0 & 8 & 0.0 & 2 & 0.0 \\
\hline Manufacturing & 93,899 & 98.7 & 115,082 & 99.1 & 116,538 & 99.1 \\
\hline Mining & 7,524 & 7.9 & 9,954 & 8.6 & 10,680 & 9.1 \\
\hline Food & 19 & 0.0 & 25 & 0.0 & 18 & 0.0 \\
\hline Textiles & 59 & 0.1 & 20 & 0.0 & 24 & 0.0 \\
\hline Paper & 27 & 0.0 & 14 & 0.0 & 12 & 0.0 \\
\hline Power generation & 3,408 & 3.6 & 1,858 & 1.6 & 1,440 & 1.2 \\
\hline Petroleum & 70,196 & 73.8 & 87,616 & 75.5 & 86,038 & 73.1 \\
\hline $\begin{array}{l}\text { Coking, gas, } \\
\text { and coal }\end{array}$ & 0 & 0.0 & 0 & 0.0 & 0 & 0.0 \\
\hline Chemicals & 9,886 & 10.4 & 12,421 & 10.7 & 14,453 & 12.3 \\
\hline Medical & 13 & 0.0 & 5 & 0.0 & 5 & 0.0 \\
\hline Chemical fibers & 2,076 & 2.2 & 2,690 & 2.3 & 3,448 & 2.9 \\
\hline Building materials & 160 & 0.2 & 231 & 0.2 & 189 & 0.2 \\
\hline Ferrous metal & 202 & 0.2 & 168 & 0.1 & 165 & 0.1 \\
\hline $\begin{array}{l}\text { Nonferrous } \\
\text { metal }\end{array}$ & 196 & 0.2 & 15 & 0.0 & 1 & 0.0 \\
\hline $\begin{array}{c}\text { Machine and } \\
\text { electricity }\end{array}$ & 84 & 0.1 & 47 & 0.0 & 52 & 0.0 \\
\hline Other products & 49 & 0.1 & 18 & 0.0 & 13 & 0.0 \\
\hline Construction & 740 & 0.8 & 508 & 0.4 & 552 & 0.5 \\
\hline Transportation & 443 & 0.5 & 455 & 0.4 & 521 & 0.4 \\
\hline Commerce & 1 & 0.0 & 6 & 0.0 & 3 & 0.0 \\
\hline $\begin{array}{l}\text { Nonmaterial } \\
\text { products }\end{array}$ & 4 & 0.0 & 12 & 0.0 & 6 & 0.0 \\
\hline Households & 0 & 0.0 & 0 & 0.0 & 0 & 0.0 \\
\hline Total consumption & 95,095 & 100.0 & 116,071 & 100.0 & 117,622 & 100.0 \\
\hline
\end{tabular}

${ }^{a}$ Values may not add because of rounding.

Source: China Statistical Yearbook (1992). 
TABLE 6 Total Natural Gas Consumption in China by Sector, 1985, 1989, and 1990 $^{\mathrm{a}}$

\begin{tabular}{|c|c|c|c|c|c|c|}
\hline \multirow[b]{2}{*}{ Sector } & \multicolumn{2}{|c|}{1985} & \multicolumn{2}{|c|}{1989} & \multicolumn{2}{|c|}{1990} \\
\hline & $\begin{array}{c}\text { Consumption } \\
\left(\text { million } \mathrm{m}^{3}\right)\end{array}$ & $\begin{array}{c}\text { Composition } \\
(\%)\end{array}$ & $\begin{array}{c}\text { Consumption } \\
\left(\text { million } \mathrm{m}^{3}\right)\end{array}$ & $\begin{array}{c}\text { Composition } \\
(\%)\end{array}$ & $\begin{array}{c}\text { Consumption } \\
\left(\text { million } \mathrm{m}^{3}\right)\end{array}$ & $\begin{array}{c}\text { Composition } \\
(\%)\end{array}$ \\
\hline Agriculture & 0 & 0.0 & 0 & 0.0 & 0 & 0.0 \\
\hline Manufacturing & 10,960 & 84.8 & 11,780 & 78.4 & 12,020 & 78.8 \\
\hline Mining & 3,710 & 28.7 & 3,960 & 26.3 & 3,780 & 24.8 \\
\hline Food & 30 & 0.2 & 30 & 0.2 & 30 & 0.2 \\
\hline Textiles & 40 & 0.3 & 20 & 0.1 & 20 & 0.1 \\
\hline Paper & 30 & 0.2 & 20 & 0.1 & 20 & 0.1 \\
\hline Power generation & 580 & 4.5 & 360 & 2.4 & 280 & 1.8 \\
\hline Petroleum & 530 & 4.1 & 870 & 5.8 & 990 & 6.5 \\
\hline $\begin{array}{l}\text { Coking, gas, } \\
\text { and coal }\end{array}$ & 0 & 0.0 & 10 & 0.1 & 10 & 0.1 \\
\hline Chemicals & 4,140 & 32.0 & 4,730 & 31.5 & 4,850 & 31.8 \\
\hline Medical & 40 & 0.3 & 30 & 0.2 & 30 & 0.2 \\
\hline Chemical fibers & 180 & 1.4 & 330 & 2.2 & 350 & 2.3 \\
\hline Building materials & 180 & 1.4 & 240 & 1.6 & 260 & 1.7 \\
\hline Ferrous metal & 520 & 4.0 & 730 & 4.9 & 950 & 6.2 \\
\hline $\begin{array}{l}\text { Nonferrous } \\
\text { metal }\end{array}$ & 0 & 0.0 & 40 & 0.3 & 30 & 0.2 \\
\hline $\begin{array}{c}\text { Machine and } \\
\text { electricity }\end{array}$ & 590 & 4.6 & 350 & 2.3 & 370 & 2.4 \\
\hline Other products & 390 & 3.0 & 60 & 0.4 & 50 & 0.3 \\
\hline Construction & 1,410 & 10.9 & 1,400 & 9.3 & 1,060 & 7.0 \\
\hline Transportation & 80 & 0.6 & 70 & 0.5 & 1.90 & 1.2 \\
\hline Commerce & 0 & 0.0 & 0 & 0.0 & 0 & 0.0 \\
\hline $\begin{array}{l}\text { Nonmaterial } \\
\text { products }\end{array}$ & 50 & 0.4 & 100 & 0.7 & 120 & 0.8 \\
\hline Households & 430 & 3.3 & 1,680 & 11.2 & 1,860 & 12.2 \\
\hline Total consumption & 12,930 & 100.0 & 15,030 & 100.0 & 15,250 & 100.0 \\
\hline
\end{tabular}

${ }^{a}$ Values may not add because of rounding.

Source: China Statistical Yearbook (1992). 
TABLE 7 Total Electricity Consumption in China by Sector, 1985,1989 , and $1990^{\mathrm{a}}$

\begin{tabular}{|c|c|c|c|c|c|c|c|}
\hline \multirow[b]{2}{*}{ Sector } & \multicolumn{2}{|c|}{1985} & \multicolumn{2}{|c|}{1989} & & \multicolumn{2}{|c|}{1990} \\
\hline & $\begin{array}{c}\text { Consumption } \\
\text { (TWh) }\end{array}$ & $\begin{array}{c}\text { Composition } \\
(\%)\end{array}$ & $\begin{array}{l}\text { Consumption } \\
\text { (TWh) }\end{array}$ & $\begin{array}{c}\text { Composition } \\
(\%)\end{array}$ & & $\begin{array}{c}\text { Consumption } \\
\text { (TWh) }\end{array}$ & $\begin{array}{c}\text { Composition } \\
(\%)\end{array}$ \\
\hline Agriculture & 31.74 & 7.7 & 41.05 & 7.0 & & 42.68 & 6.9 \\
\hline Manufacturing & 328.34 & 79.7 & 464.65 & 79.2 & & 487.33 & 78.2 \\
\hline Mining & 43.29 & 10.5 & 64.47 & 11.0 & & 67.51 & 10.8 \\
\hline Food & 10.86 & 2.6 & 18.22 & 3.1 & & 18.23 & 2.9 \\
\hline Textiles & 18.57 & 4.5 & 24.34 & 4.1 & & 24.66 & 4.0 \\
\hline Paper & 8.09 & 2.0 & 11.44 & 2.0 & & 11.98 & 1.9 \\
\hline Power generation & 58.81 & 14.3 & 84.65 & 14.4 & & 88.77 & 14.2 \\
\hline Petroleum & 4.02 & 1.0 & 6.44 & 1.1 & & 7.15 & 1.1 \\
\hline $\begin{array}{l}\text { Coking, gas, } \\
\text { and coal }\end{array}$ & 0.86 & 0.2 & 1.39 & 0.2 & & 1.59 & 0.3 \\
\hline Chemicals & 51.35 & 12.5 & 70.71 & 12.1 & & 73.51 & 11.8 \\
\hline Medical & 2.32 & 0.6 & 3.88 & 0.7 & & 4.23 & 0.7 \\
\hline Chemical fibers & 3.34 & 0.8 & 5.50 & 0.9 & & 5.92 & 1.0 \\
\hline Building materials & 22.16 & 5.4 & 32.70 & 5.6 & & 33.08 & 5.3 \\
\hline Ferrous metal & 36.32 & 8.8 & 51.58 & 8.8 & & 55.57 & 8.9 \\
\hline $\begin{array}{l}\text { Nonferrous } \\
\text { metal }\end{array}$ & 17.39 & 4.2 & 25.51 & 4.3 & & 26.99 & 4.3 \\
\hline $\begin{array}{c}\text { Machine and } \\
\text { electricity }\end{array}$ & 32.03 & 7.8 & 36.49 & 6.2 & & 36.60 & 5.9 \\
\hline Other products & 18.93 & 4.6 & 27.33 & 4.7 & & 31.54 & 5.1 \\
\hline Construction & 7.12 & 1.7 & 6.52 & 1.1 & & 6.50 & 1.0 \\
\hline Transportation & 6.34 & 1.5 & 9.87 & 1.7 & $\cdot$ & 10.59 & 1.7 \\
\hline Commerce & 3.80 & 0.9 & 6.87 & 1.2 & & 7.62 & 1.2 \\
\hline $\begin{array}{l}\text { Nonmaterial } \\
\text { products }\end{array}$ & 12.17 & 3.0 & 18.05 & 3.1 & & 20.24 & 3.2 \\
\hline Households & 22.25 & 5.4 & 39.52 & 6.7 & & 48.08 & 7.7 \\
\hline Total consumption & 411.76 & 100.0 & 586.53 & 100.0 & & 623.00 & 100.0 \\
\hline
\end{tabular}

${ }^{a}$ Values may not add because of rounding,

Source: China Statistical Yearbook (1992). 
TABLE 8 Total Coke Consumption in China by Sector, 1985, 1989, and $1990^{\mathrm{a}}$

\begin{tabular}{|c|c|c|c|c|c|c|}
\hline \multirow[b]{2}{*}{ Sector } & \multicolumn{2}{|c|}{1985} & \multicolumn{2}{|c|}{1989} & \multicolumn{2}{|c|}{1990} \\
\hline & $\begin{array}{l}\text { Consumption } \\
(1,000 \text { tonnes })\end{array}$ & $\begin{array}{c}\text { Composition } \\
(\%)\end{array}$ & $\begin{array}{l}\text { Consumption } \\
(1,000 \text { tonnes })\end{array}$ & $\begin{array}{c}\text { Composition } \\
(\%)\end{array}$ & $\begin{array}{l}\text { Consumption } \\
(1,000 \text { tonnes })\end{array}$ & $\begin{array}{c}\text { Composition } \\
(\%)\end{array}$ \\
\hline Agriculture & 208 & 0.4 & 535 & 0.8 & 601 & 0.9 \\
\hline Manufacturing & 46,227 & 98.6 & 62,571 & 98.3 & 68,088 & 98.5 \\
\hline Mining & 717 & 1.5 & 1,028 & 1.6 & 1,041 & 1.5 \\
\hline Food & 123 & 0.3 & 209 & 0.3 & 226 & 0.3 \\
\hline 'Textiles & 71 & 0.2 & 116 & 0.2 & 107 & 0.2 \\
\hline Paper & 9 & 0.0 & 27 & 0.0 & 25 & 0.0 \\
\hline Power generation & 31 & 0.1 & 26 & 0.0 & 12 & 0.0 \\
\hline Petroleum & 41 & 0.1 & 22 & 0.0 & 11 & 0.0 \\
\hline $\begin{array}{l}\text { Coking, gas, } \\
\text { and coal }\end{array}$ & 141 & 0.3 & 493 & 0.8 & 766 & 1.1 \\
\hline Chemicals & 7,219 & 15.4 & 8,926 & 14.0 & 9,462 & 13.7 \\
\hline Medical & 3 & 0.0 & 6 & 0.0 & 31 & 0.0 \\
\hline Chemical fibers & 100 & 0.2 & 176 & 0.3 & 146 & 0.2 \\
\hline Building materials & 935 & 2.0 & 1,768 & 2.8 & 1,822 & 2.6 \\
\hline Ferrous metal & 32,372 & 69.0 & 43,406 & 68.2 & 48,097 & 69.6 \\
\hline $\begin{array}{l}\text { Nonferrous } \\
\text { metal }\end{array}$ & 731 & 1.6 & 1,156 & 1.8 & 1,120 & 1.6 \\
\hline $\begin{array}{c}\text { Machine and } \\
\text { electricity }\end{array}$ & 2,601 & 5.5 & 3,691 & 5.8 & 3,754 & 5.4 \\
\hline Other products & 1,133 & 2.4 & 1,521 & 2.4 & 1,468 & 2.1 \\
\hline Construction & 78 & 0.2 & 91 & 0.1 & 52 & 0.1 \\
\hline Transportation & 57 & 0.1 . & 46 & 0.1 & 41 & 0.1 \\
\hline Commerce & 27 & 0.1 & 87 & 0.1 & 77 & 0.1 \\
\hline $\begin{array}{l}\text { Nonmaterial } \\
\text { products }\end{array}$ & 20 & 0.0 & 41 & 0.1 & 19 & 0.0 \\
\hline Households & 230 & 0.5 & 313 & 0.5 & 269 & 0.4 \\
\hline Total consumption & 46,897 & 100.0 & 63,684 & 100.0 & 69,147 & 100.0 \\
\hline
\end{tabular}

${ }^{a}$ Values may not add because of rounding.

Source: China Statistical Yearbook (1992). 
Section 5 presents the major technical aspects of the model. These aspects relate to energy reserves, energy technology, and GHG emissions. Again, a set of upper- and lowerbound parameters is identified for subsequent simulation and sensitivity analyses.

Section 6 uses the model presented in Section 4, together with the economic and technical data presented in Sections 3 and 5, respectively, to predict the impact of a $\mathrm{CO}_{2}$ mitigation requirement on China's economic growth for each milestone year. The policy requirement calls for stabilizing emissions to $80 \%$ of year 2000 baseline levels, though with a phased-in compliance schedule. Appendixes A-D present supporting data.

The results are interesting and, in most cases, robust; i.e., they are not very sensitive to the choice of economic or technical parameters. The required mitigation can be obtained by a varied set of strategies that have few adverse effects on economic growth in the year 2000 and even in 2010. However, the number of options capable of attaining the mitigation target alone, or even together, is reduced dramatically by 2025 , and significantly negative impacts on economic growth set in. 


\section{CHINESE INPUT-OUTPUT TABLE}

\subsection{INTRODUCTION TO INPUT-OUTPUT ANALYSIS}

Every national economy has some degree of interdependence. Each production unit (e.g., private company or state-owned enterprise) relies on outside input into its production process. As a result, a single business enterprise contributes to a nation's economy far beyond its own production because it demands a succession of upstream inputs from its suppliers and downstream deliveries to its customers. The sum of these many rounds of derived demands and commodity allocations can be a large multiple of the value of the initial production. Hence, each industry generates multiplier, or development linkage, effects.

Input-output analysis is one of the most widely used tools in economic analysis. Developed by Nobel laureate Wassily Leontief (1986), I-O analysis has been applied in nearly every country to examine a range of topics. Such topics include the effects of economic development projects, international trade policies, technological changes, and environmental regulations. Input-output analysis has been used most frequently in the centrally planned economies of China, the former Soviet Union, and the countries of Eastern Europe, where a substitute provided the detailed information typically offered by the marketplace. In other contexts, I-O analysis has been widely used in formulating national policies and ensuring consistency between them and the decisions of individual businesses and consumers (e.g., "indicative planning" in France).

The basic I-O model is an operational, static, linear model of purchases and sales between sectors of the economy, based on the technical relations of production (e.g., Miller and Blair 1985). Many of the limitations of the basic model have been overcome by progress toward a more general model, which is generally still operational. This I-O model is a dynamic, nonlinear model of purchases and sales of commodities between sectors and institutions of an economy or economies based on the technical relationship of production and other important quantifiable variables.

To some, the general I-O definition may no longer seem to be I-O, but it does include the critical essence of the formulation. There is nothing essential about static or linear characteristics. Instead, the fundamental contributions of I-O analysis stem from such attributes as operational, model, double-entry accounting of economic interdependence; a manageable grouping of decision units; general equilibrium comprehensiveness (even across space); and the realities of technological limits. In this light, the current state of the art of I-O economics represents a formidable modeling option with a wide range of applications (Rose and Miernyk 1989).

An I-O table provides an explicit set of economic accounts for a given geographic area. This accounting system is based on a fundamental identity: that the total production of any industry, or sector, equals the amount of its products used by other businesses to produce their output plus the amount demanded for final use by consumers, investment, government, and exporters. 
Figure 1 presents a schematic of the major components of an I-O table. Quadrant I corresponds to the final use of goods and services, or the net output of the economy. Quadrant II contains interindustry transactions that reflect the technological needs or purchases of each industry. It represents the processing of intermediate goods, i.e., goods produced for industry rather than for consumers (e.g., government expenditure, investment, or export $)^{1}$ needs. Quadrant III corresponds to returns to primary factors or value added (e.g., wages, salaries, profits, or taxes) that emanate from intermediate sectors. Quadrant IV represents value added associated with final demand activities (e.g., domestic help and government payrolls).

At any given time, the I-O table provides an excellent, compact snapshot of an economy. It portrays the economy's diversity, its leading producing and consuming sectors, and the role of imports and exports. It can be appended with a set of environmental accounts that link economic activity and pollution. Measures taken to mitigate this pollution can be incorporated into the table as input substitutions, energy productivity improvements, process changes, and changes in the product mix.

In mathematical terms, the basic I-O balance equation can be written compactly in matrix notation:

$$
\boldsymbol{X}=\mathbf{A X}+\boldsymbol{Y}
$$

where

$\boldsymbol{X}=$ total gross output of sector $i$

$\mathbf{A}=$ matrix of technical coefficients (each element represents the direct inputs of good $i$ needed to produce $\$ 1$ of $\operatorname{good} j$ ); and

$\boldsymbol{Y}=$ autonomous final demand for the products of sector $i$.

The vector of annual gross output needed to deliver the exogenously given set of final demands can be solved as follows:

$$
\boldsymbol{X}=(\mathbf{I}-\mathbf{A})^{-1} \boldsymbol{Y}
$$

The $(\mathbf{I}-\mathbf{A})^{-1}$ matrix is known as the Leontief Inverse. Each element represents the total direct and indirect effect on the gross output of sector $i$, corresponding to a one-unit change in final demand for good $j$. The sum of elements in a given column is known as the output multiplier for that sector. In this way, the I-O model captures the less apparent, but often sizable, multiplier effects of a change in economic conditions (e.g., major capital investment spending).

1 In China's I-O table, these categories are institutional consumption and fixed capital formation, respectively. Exports are shown as the net of imports. 


\begin{tabular}{|c|c|c|c|c|c|c|}
\hline $\mid$ Inputs & 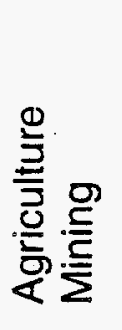 & 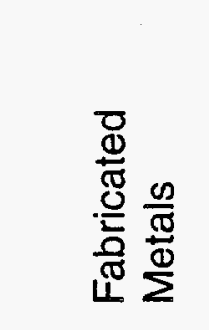 & 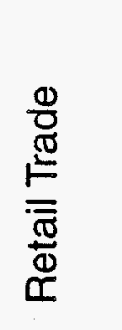 & 哭 & 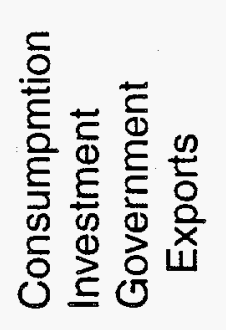 & 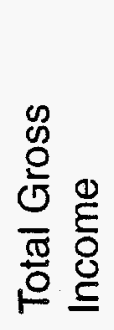 \\
\hline $\begin{array}{l}\text { Agriculture } \\
\text { Mining }\end{array}$ & \multirow{4}{*}{\multicolumn{3}{|c|}{$\begin{array}{c}\text { II } \\
\text { Intermediate Goods } \\
\text { Processing }\end{array}$}} & & \multirow{4}{*}{$\begin{array}{c}\text { I } \\
\text { Final } \\
\text { Demands }\end{array}$} & \\
\hline $\begin{array}{l}\text { Fabricated } \\
\text { Metals }\end{array}$ & & & & & & \\
\hline Retail Trade & & & & & & \\
\hline Utilities & & & & & & \\
\hline $\begin{array}{l}\text { Wages } \\
\text { Profits } \\
\text { Taxes }\end{array}$ & \multicolumn{4}{|c|}{$\begin{array}{c}\text { III } \\
\text { Value Added }\end{array}$} & $\begin{array}{l}\text { IV } \\
\text { Value } \\
\text { Added }\end{array}$ & \\
\hline $\begin{array}{l}\text { Total Gross } \\
\text { Outlays }\end{array}$ & & & & & & $=$ \\
\hline
\end{tabular}

FIGURE 1 Schematic of the Major Components of an Input-Output Table

\subsection{CHINESE 1987 INPUT-OUTPUT TABLE}

\subsubsection{Basic Features}

Before the 1987 I-O table was created, China based its economic accounts only on the material production system (MPS). Tables based on this system do not include rows for the service industries in the transactions quadrant, although these purchases are included in the final consumption column. For example, in the MPS, household consumption includes both goods purchased directly by households and the imputed value of goods produced by 
households for their own use. In the interindustry transactions quadrant (II), intermediate consumption includes only material products consumed by material sectors.

Because firms that produce services outside the material product sector are increasingly important in China's economy, the $1987 \mathrm{I}-\mathrm{O}$ table includes them in the interindustry transactions quadrant. The 1987 I-O table was constructed by using the System of National Accounts (SNA) definitions. Most market-oriented or mixed economies use this system (with some changes). Some changes involve dividing the sectors in the interindustry transactions quadrant into material and nonmaterial products. Others involve dividing the total accumulation sector, which is composed of fixed capital formation and changes in stock in the SNA, into both material and nonmaterial products. Therefore, the table can be considered to be a qualitative hybrid of both MPS and SNA. Essentially, the latest Chinese I-O table contains all of the information in the SNA and further distinguishes between material and nonmaterial production.

\subsubsection{Summary Description of the 1987 Input-Output Table}

\subsubsection{Total Supply and Demand}

In 1987, the total supply of goods and services in China was $2,745.16$ billion yuan (Table 9). This total consisted of gross output of $2,566.28$ billion yuan ( $93.5 \%$ of the total) and imports of 178.88 billion yuan (6.5\%). The total demand was also 2,566.28 billion yuan: 2,558.01 billion yuan of domestic demand (94.3\% of the total) and exports of 157.15 billion yuan $(5.7 \%)$. The proportion of foreign trade in China's economy was relatively small compared with other developing countries. Intermediate demand was about 10 percentage points higher than domestic final demand in total domestic demand.

\subsubsection{Interindustry Transactions and Final Demand}

The manufacturing sector supplied the highest proportion of output to intermediate and final demand, including its major components: consumption (both households and institutional [government]) and capital accumulation (Table 10). In 1987, gross output in manufacturing was $1,381.2$ billion yuan, which made up $57.8 \%$ of the total gross output. The sector contributed $69.2 \%$ of interindustry demand and $37.4 \%$ of total consumption. Construction supplied the highest proportion of investment in the economy $(55.6 \%$ of total accumulation).

The large proportion of construction in total accumulation reflects the fact that China's economic growth in the 1980s was largely due to retrofitting existing heavy industry and developing light manufacturing industry, which induced large-scale construction work. The nonmaterial product sector output was 303 billion yuan (12.0\% of the total gross output). The sector also contributed a large proportion (28.5\%) of total consumption. In the 
TABLE 9 Composition of Total Supply and Demand in China, 1987

\begin{tabular}{lrc}
\hline \multicolumn{1}{c}{ Item } & $\begin{array}{c}\text { Amount } \\
\text { (billions of yuan) }\end{array}$ & $\begin{array}{c}\text { Composition } \\
(\%)\end{array}$ \\
\hline Supply & & \\
Total gross output & $2,566.28$ & 93.5 \\
Total intermediate output & $1,428.88$ & 51.9 \\
Value added & $1,142.41$ & 41.6 \\
Labor income & 568.12 & 20.7 \\
Profit and tax & 336.19 & 12.2 \\
Depreciation & 120.15 & 4.4 \\
Other factors & 117.94 & 4.3 \\
Imports & 178.88 & 6.5 \\
Total & $2,745.16$ & 100.0 \\
& & \\
Demand & & \\
Total domestic demand & $2,588.01$ & 94.3 \\
Domestic final demand & $1,164.60$ & 42.4 \\
Intermediate demand & $1,423.41$ & 51.9 \\
Exports & 157.15 & 5.7 \\
Total & & \\
\hline
\end{tabular}

Source: China Statistical Yearbook (1988).

manufacturing sector, the food, chemical, and textile industries constituted the three largest proportions of total gross output: $7.2,7.1$, and $6.5 \%$, respectively. The chemical industry supplied the highest proportion of interindustry demand of any manufacturing sector. Machinery supplied the second largest proportion of total accumulation, preceded by construction. The food industry supplied the highest proportion of consumption (15.6\% of total consumption).

\subsubsection{Material Consumption and Value Added}

Material consumption consists of both intermediate inputs and depreciation (Table 11). The proportion of material consumption relative to total output of each of these components was obtained by partitioning the 1987 I-O table into building blocks. Construction supplied the highest proportion of material demand - 73.5\% of total output; agriculture had the lowest - 33.7\%. Agriculture showed the highest proportion of labor cost (57.6\% of total output in the sector), reflecting the high labor intensity of China's agriculture.

The proportion of profits and taxes in commerce was very low (1.0\% of total commercial output) because China's government significantly restricted commerce, and 
TABLE 10 Percentage of Chinese Output Structure by Sector, 1987

\begin{tabular}{lrccc}
\hline \multicolumn{1}{c}{ Sector } & $\begin{array}{c}\text { Total } \\
\text { Output }\end{array}$ & $\begin{array}{c}\text { Interindustry } \\
\text { Demand }\end{array}$ & $\begin{array}{c}\text { Total } \\
\text { Consumption }\end{array}$ & $\begin{array}{c}\text { Total Capital } \\
\text { Accumulation }\end{array}$ \\
\hline Agriculture & 18.2 & 15.3 & 30.0 & 4.9 \\
Mining & 3.3 & 5.4 & 0.7 & 0.0 \\
Manufacturing & 57.8 & 69.2 & 37.4 & 37.3 \\
Food & 7.2 & 4.2 & 15.6 & 1.1 \\
Textiles & 6.5 & 7.4 & 5.2 & 1.3 \\
Chemicals & 7.1 & 12.0 & 2.8 & 1.1 \\
Primary metals & 4.2 & 8.6 & 0.0 & 0.3 \\
Machinery & 5.5 & 5.3 & 1.6 & 16.7 \\
Others & 20.0 & 26.3 & 11.4 & 15.9 \\
Construction & 9.5 & 0.0 & 0.0 & 55.6 \\
Transportation and & 2.7 & 3.1 & 1.7 & 0.9 \\
communication & & & & 2.2 \\
Commerce (trade) & 4.0 & 6.0 & 2.4 & 0.0 \\
Nonmaterial production & 12.0 & 6.4 & 28.5 & 100.0 \\
Total (\%) & & & & 437.3 \\
\hline Total cost (billions of yuan) & $2,566.3$ & $1,423.9$ & 727.3 & \\
\hline
\end{tabular}

Source: China Statistical Yearbook (1988).

privatization was not yet effective. In the manufacturing sector, most individual industries showed very low labor costs, especially among light industries such as food, textiles, and paper. This fact reflects the Chinese economy's dependence on low wages to fuel its international competitiveness. Low labor costs are also reflected in the country's increasing exports of light industrial products in the world market since the mid-1980s.

\subsubsection{Input-Output Transactions Table}

The basis of the simulations in this report is a 1990 update of China's 1987 I-O table (Table 12). In the absence of detailed data on sectoral gross output and final demand growth, a proportional extrapolation of the 1987 table was performed, based on GDP growth. ${ }^{2}$

Another major modification of the 1987 I-O table improved the accuracy of the simulations to be performed below. In China's $1987 \mathrm{I}-\mathrm{O}$ table, the total direct requirements

2 Limited data were available, but to use these data would have required rebalancing all the technical coefficients in the table. It was determined that any errors from such a procedure would be greater than holding the coefficients constant. 
TABLE 11 Percentage of Material Consumption and Value Added to Total Output, $1987^{\mathfrak{a}}$

\begin{tabular}{|c|c|c|c|c|c|}
\hline \multirow[b]{3}{*}{ Sector } & \multirow{2}{*}{\multicolumn{2}{|c|}{ Material Consumption }} & \multicolumn{3}{|c|}{ Value Added } \\
\hline & & & \multirow{2}{*}{$\begin{array}{c}\text { Labor } \\
\text { Cost }\end{array}$} & \multirow{2}{*}{$\begin{array}{c}\text { Profit } \\
\text { and Tax }\end{array}$} & \multirow[b]{2}{*}{ Other } \\
\hline & Intermediate & Depreciation & & & \\
\hline \multicolumn{6}{|l|}{ Manufacturing } \\
\hline Agriculture & 31.5 & 2.2 & 57.6 & 6.1 & 2.7 \\
\hline Food & 73.7 & 1.9 & 4.0 & 16.4 & 4.0 \\
\hline Textiles & 74.4 & 2.8 & 7.2 & 12.5 & 3.2 \\
\hline Chemicals & 67.6 & 4.8 & 5.9 & 18.0 & 3.6 \\
\hline Machinery & 64.8 & 4.6 & 10.3 & 16.6 & 3.7 \\
\hline Total & 67.9 & 4.9 & 8.2 & 16.4 & 2.0 \\
\hline Construction & 71.4 & 2.1 & 20.3 & 3.9 & 2.3 \\
\hline $\begin{array}{l}\text { Transportation and } \\
\text { communication }\end{array}$ & 37.0 & 15.4 & 19.5 & 22.0 & 6.2 \\
\hline Commerce & 46.3 & 5.4 & 38.7 & 1.0 & 8.6 \\
\hline Nonmaterial production & 30.2 & 7.0 & 27.4 & 16.0 & 19.5 \\
\hline Total & 100.0 & 100.0 & 100.0 & 100.0 & 100.0 \\
\hline
\end{tabular}

a Values may not add because of rounding.

Source: China Statistical Yearbook (1988).

were composed of both goods produced in China and imports. (A separate import column is entered into final demand, but the sectoral use of imports is not as apparent. In addition, the impact computations are more complex in this format than in the modified one.) By calculating a pure intranational table, domestically produced goods were separated from imports. Thus, Table 12 shows a set of 33 sectors plus a distinct quadrant in the middle of the table that represents the purchases of imported goods (note that China imports such goods as metal ores, sawmills, and chemicals but is self-sufficient in goods such as agriculture and coal mining).

To understand the contents of the I-O table, it is important to understand certain conventions. The sectors listed in the left margin (row labels) represent selling sectors, and the sectors listed at the top represent purchasing sectors. (Because of space restrictions, sector numbers only appear along the top margin, but the reader should keep in mind that the sectors are in the same order in both the rows and the columns.) Hence, along any row, the table displays the sales of the sector to the left of each intermediate sector listed along the top margin, plus sales to final demand. For example, sector 2 (coal mining) sells 37 million yuan to sector 1 (agriculture). However, sector 2's largest customer is sector 11 (electricity services), to which it sells 11,450 million yuan. Most sectors use coal, often for processed steam or heat, which is the reason this report examines an electrification strategy 
TABLE 121990 Chinese Input-Output Table (in million yuan) (pure intranational table, imports appear in bottom rows)

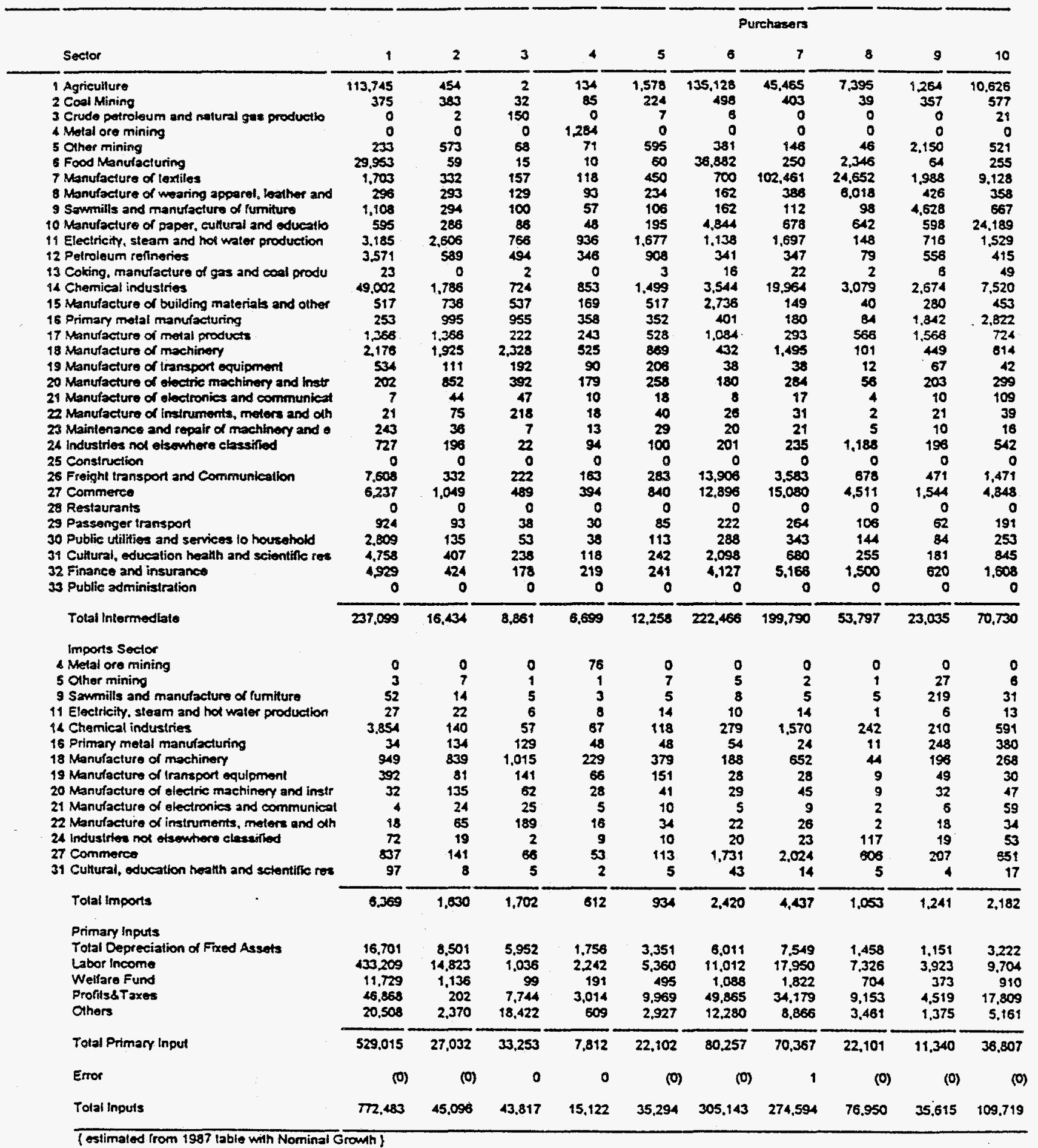


TABLE 12 (Cont.)

\begin{tabular}{|c|c|c|c|c|c|c|c|c|c|c|c|c|c|c|}
\hline \multicolumn{15}{|c|}{ Purchasers } \\
\hline Sector & $\$ 1$ & 12 & 13 & 14 & 15 & 16 & 17 & 18 & 19 & 20 & 21 & 22 & 23 & 24 \\
\hline 1 & 23 & 4 & 9 & 20.476 & 9.177 & 198 & 188 & 382 & 80 & 417 & 10 & 9 & 75 & 400 \\
\hline 2 & 11,450 & 13 & 4.150 & 3.680 & 5.274 & 4.656 & 311 & 692 & 147 & 223 & 40 & 20 & 97 & 51 \\
\hline 3 & 2,477 & 27,298 & 361 & 5,585 & 137 & 538 & 51 & 100 & 11 & 9 & 4 & 0 & 4 & 1 \\
\hline 4 & 0 & 0 & 0 & 516 & 0 & 12,857 & 757 & 306 & 13 & 0 & 0 & 0 & 0 & 0 \\
\hline 5 & 442 & 15 & 58 & 4,060 & 3,087 & 606 & 348 & 447 & 94 & 112 & 38 & 17 & 65 & 37 \\
\hline 6 & 55 & 6 & 35 & 8,847 & 188 & 189 & 120 & 221 & 56 & 183 & 34 & 18 & 14 & 22 \\
\hline 7 & 219 & 26 & 58 & 10,613 & 2,125 & 655 & 2,548 & 1.938 & 508 & 525 & 189 & 75 & 427 & 1.599 \\
\hline a & 111 & 28 & 72 & 933 & 854 & 682 & 381 & 1.062 & 244 & 262 & 112 & 54 & 136 & 240 \\
\hline 9 & 34 & 13 & 28 & 45 & 887 & 277 & 610 & 2.072 & 380 & 540 & 129 & 98 & 140 & 177 \\
\hline 10 & 224 & 29 & 52 & 4.349 & 7,830 & 517 & 1.736 & 1.888 & 232 & 2,400 & 631 & 156 & 133 & 448 \\
\hline 19 & 8,175 & 237 & 430 & 9,659 & 8.031 & 8,295 & 1.657 & 3,406 & 588 & 978 & 345 & 104 & 414 & 219 \\
\hline 12 & 3,827 & 740 & 317 & 4.870 & 4.409 & 2.773 & 672 & 1.986 & 519 & 848 & 156 & 47 & 344 & 124 \\
\hline 13 & 33 & 1 & 241 & 105 & 447 & 5.976 & 327 & 572 & 52 & 69 & 9 & 2 & 28 & 14 \\
\hline 14 & 513 & 720 & 250 & 80.619 & 7,917 & 3,437 & 4,151 & 10,573 & 4.633 & 9,954 & 3,887 & 616 & 1,122 & 1,618 \\
\hline 45 & 349 & 156 & 105 & 2.720 & 9.689 & 4.726 & 1.172 & 2,528 & 795 & 2,573 & 1,288 & 218 & 424 & 130 \\
\hline 16 & 347 & a4 & 219 & 2.527 & 4,706 & 12,844 & 20,072 & 26,220 & 5,671 & 15.595 & 1.656 & 823 & 1.558 & 956 \\
\hline 17 & 252 & 53 & 113 & 2.736 & 2.226 & 1,477 & 4,474 & 5,619 & 906 & 2,640 & 811 & 287 & 518 & 306 \\
\hline 18 & 666 & 157 & 208 & 2.852 & 2,844 & 5,287 & 1,531 & 32,631 & 4,997 & 3,627 & 536 & 457 & 1,634 & 224 \\
\hline 19 & 98 & 16 & 30 & 193 & 337 & 456 & 188 & 1,243 & 8,588 & 90 & 37 & 17 & 1,665 & 143 \\
\hline 20 & 788 & 47 & 91 & 1,079 & 1,245 & 1.496 & 752 & 90,687 & 1,725 & 10,826 & 2,500 & 550 & 875 & 142 \\
\hline 29 & 58 & 8 & $\theta$ & 90 & 63 & 126 & 87 & 874 & 257 & 512 & 17.121 & 646 & 71 & 50 \\
\hline 22 & 157 & 62 & 30 & 429 & 145 & 339 & 104 & 857 & 180 & 558 & 214 & 663 & 111 & 61 \\
\hline 23 & 48 & 7 & 12 & 67 & 72 & 106 & 52 & 92 & 20 & 23 & 13 & 3 & 55 & 4 \\
\hline 24 & 953 & 5 & 30 & 498 & 747 & 776 & 812 & 796 & 162 & 473 & 194 & 77 & 79 & 2.110 \\
\hline 25 & 0 & 0 & 0 & 0 & 0 & 0 & 0 & 0 & 0 & 0 & 0 & 0 & 0 & 0 \\
\hline 26 & 1.262 & 2.084 & 439 & 4.674 & 2.206 & 3.194 & 1.125 & 2.879 & 890 & 1.122 & 376 & 102 & 280 & 231 \\
\hline 27 & 1,233 & 1.464 & 328 & 12.219 & 4.055 & 5.858 & 2,922 & 8,367 & 2.347 & 4,072 & 2.705 & 404 & 732 & 897 \\
\hline 28 & 0 & 0 & 0 & 0 & 0 & 0 & 0 & 0 & 0 & 0 & 0 & 0 & 0 & 0 \\
\hline 29 & 96 & 18 & 10 & 424 & 254 & 124 & 146 & 546 & 198 & 177 & 111 & 46 & 53 & 43 \\
\hline 30 & 132 & 23 & 13 & 578 & 329 & 182 & 185 & 709 & 152 & 237 & 148 & 62 & 69 & 55 \\
\hline 31 & 245 & 62 & 42 & 1.730 & 920 & 465 & 448 & 1,542 & 347 & 566 & 293 & 111 & 166 & 142 \\
\hline 32 & 129 & 91 & 50 & 4.536 & 2.353 & 2,208 & 1,401 & 4,753 & 1,245 & 2,121 & 1.527 & 335 & 332 & 345 \\
\hline \multirow[t]{2}{*}{33} & 0 & 0 & 0 & 0 & 0 & 0 & 0 & 0 & 0 & 0 & 0 & 0 & 0 & 0 \\
\hline & 26,658 & 33,461 & 7.788 & 192.208 & 74.154 & 110,518 & 49,323 & 125,981 & 35.954 & 61,729 & 35.112 & 6,018 & 11,620 & 10.788 \\
\hline
\end{tabular}

\begin{tabular}{|c|c|c|c|c|c|c|c|c|c|c|c|c|c|}
\hline 4 & 0 & 0 & 30 & 0 & 759 & 45 & 18 & 1 & 0 & 0 & 0 & 0 & 0 \\
\hline 5 & 0 & 1 & so & 38 & 8 & 4 & 6 & 1 & 1 & 0 & 0 & 1 & 0 \\
\hline 4 & 1 & 1 & 21 & 32 & 13 & 29 & 98 & 18 & 25 & 6 & 5 & 7 & 8 \\
\hline 10 & 2 & 4 & 81 & 67 & 69 & 14 & 29 & 5 & 8 & 3 & 1 & 3 & 2 \\
\hline 40 & 57 & 20 & 6,341 & 623 & 270 & 326 & 832 & 364 & 783 & 306 & 48 & 88 & 127 \\
\hline 47 & 11 & 29 & 354 & 634 & 5.774 & 2.705 & 3,534 & 764 & 2,102 & 223 & 111 & 210 & 129 \\
\hline 290 & 69 & 91 & 1.243 & 1,240 & 2.305 & 667 & 14,224 & 2.178 & 1,581 & 234 & 199 & 712 & 98 \\
\hline 72 & 12 & 22 & 142 & 247 & 334 & 138 & 911 & 6.294 & 66 & 27 & 13 & 1,220 & 105 \\
\hline 125 & 7 & 14 & 171 & 197 & 237 & 119 & 1,694 & 273 & 1.716 & 396 & 87 & 139 & 22 \\
\hline 31 & 5 & 3 & 48 & 34 & 68 & 47 & 471 & 138 & 276 & 9,228 & 348 & 38 & 27 \\
\hline 137 & 54 & 26 & 372 & 126 & 294 & 87 & 744 & 156 & 484 & 183 & 576 & 96 & 53 \\
\hline 15 & 1 & 3 & 49 & 73 & 76 & 80 & 78 & 16 & 47 & 19 & 8 & 8 & 208 \\
\hline 166 & 196 & 44 & 1,640 & 544 & 786 & 392 & 1.123 & 315 & 546 & 363 & 54 & 98 & 120 \\
\hline 31 & 1 & 1 & 35 & 19 & 9 & 9 & 31 & 7 & 12 & 6 & 2 & 3 & 3 \\
\hline 947 & 415 & 259 & 10,578 & 3.875 & 11,003 & 4.863 & 23,793 & 10,531 & 7.648 & 10,996 & 1,452 & 2,624 & 903 \\
\hline 7.903 & 2.159 & 675 & 14,451 & 7,194 & 9.844 & 2,293 & 10,582 & 2,840 & 2,691 & 2.100 & 570 & 1,448 & 640 \\
\hline 3,151 & 665 & 790 & 16,342 & 17,797 & 8.394 & 7.623 & 21.741 & 4,643 & 6,309 & 3.537 & 1.503 & 3.425 & 1.704 \\
\hline 337 & 60 & 75 & 1.558 & 1.672 & 736 & 724 & 2,083 & 398 & 614 & 334 & 147 & 330 & 150 \\
\hline 23,483 & 22,185 & 32 & 54.042 & 22,119 & 33,710 & 12,236 & 38,356 & 9.587 & 16,077 & 10,084 & 2,738 & 2,748 & 2,384 \\
\hline 2.667 & 1.250 & 377 & 10,867 & 5,401 & 5,294 & 3.115 & 8.532 & 2,322 & 3,385 & 2,097 & 598 & 1,076 & 737 \\
\hline 37,541 & 26.319 & 1.949 & 97,260 & 54.183 & 57.978 & 25.991 & 81,292 & 19.791 & 29,076 & 18,153 & 5,555 & 9,027 & 5,615 \\
\hline (0) & 0 & (1) & (0) & (0) & (0) & (0) & 0 & 0 & (0) & (0) & 0 & 0 & 0 \\
\hline 65,146 & 60,196 & 9,995 & 300,046 & 132.211 & 179,499 & 79,976 & 231.066 & 66,277 & 98.453 & 64,260 & 13.025 & 23,270 & 17,305 \\
\hline
\end{tabular}


TABLE 12 (Cont.)

\begin{tabular}{|c|c|c|c|c|c|c|c|c|c|c|c|c|}
\hline \multirow[b]{2}{*}{ Sector } & \multirow[b]{2}{*}{25} & \multirow[b]{2}{*}{26} & \multirow[b]{2}{*}{27} & \multirow[b]{2}{*}{28} & \multicolumn{2}{|c|}{ Purchasers } & \multirow[b]{2}{*}{31} & \multirow[b]{2}{*}{32} & \multirow[b]{2}{*}{33} & \multirow[b]{2}{*}{$\begin{array}{c}\text { Tolal } \\
\text { Intermediate }\end{array}$} & \multirow[b]{2}{*}{$\begin{array}{r}\text { Fina! } \\
\text { Demand }\end{array}$} & \multirow[b]{2}{*}{$\begin{array}{l}\text { Total } \\
\text { Outpul }\end{array}$} \\
\hline & & & & & 29 & 30 & & & & & & \\
\hline 1 & 1,953 & 12 & 2,892 & 12,063 & 0 & 1,050 & 2,665 & 1 & 160 & 360.040 & 412,443 & 772,483 \\
\hline 2 & 429 & 696 & 436 & 76 & 134 & 617 & 860 & 11 & 235 & 37.271 & 7.025 & 45,098 \\
\hline 3 & 5 & 77 & 8 & 4 & 0 & 15 & 57 & 0 & 0 & 36.930 & 6.886 & 43,817 \\
\hline 4 & 0 & 0 & 0 & 0 & 0 & 0 & 31 & 0 & 0 & 15.764 & (642) & 15,122 \\
\hline 5 & 19,125 & 187 & 427 & 63 & 40 & 372 & 878 & 8 & 169 & 35,478 & (984) & 35,294 \\
\hline 6 & 352 & 47 & 9.776 & 15,275 & 125 & 1.463 & 658 & 3 & 78 & 99,660 & 205,483 & 305,143 \\
\hline 7 & 2,138 & 692 & 5,129 & 201 & 273 & 1,013 & 1,989 & 54 & 250 & 174,932 & 99,662 & 274,594 \\
\hline 8 & 1.807 & 538 & 1.015 & 66 & 85 & 327 & 666 & 28 & 303 & 18,231 & 58,719 & 78,950 \\
\hline 9 & 9.614 & 40 & 1.801 & 117 & 100 & 809 & 1.174 & 55 & 151 & 27.274 & 8,341 & 35,615 \\
\hline 90 & 1.323 & 872 & 6.455 & 958 & 153 & 843 & 16.177 & 327 & 3.323 & 82.410 & 27.310 & 109,719 \\
\hline 11 & 1,862 & 1.056 & 1.406 & 310 & 135 & 1,266 & 2,816 & 19 & 293 & 59,099 & 6,046 & 65.146 \\
\hline 12 & 6,264 & 13,339 & 1,487 & 132 & 2,661 & 1.933 & 1,688 & 39 & 1.488 & 58,309 & 1.888 & 60,196 \\
\hline 13 & 84 & 12 & 56 & 49 & 1 & 40 & 129 & 5 & 32 & 7,610 & 2,386 & 9,995 \\
\hline 14 & 10,309 & 3.490 & 2,456 & 156 & 426 & 2,089 & 21,339 & 44 & 195 & 261.160 & 38,886 & 300,046 \\
\hline 15 & 90,592 & 432 & 2,817 & 289 & 95 & 2.691 & 3,472 & 70 & 379 & 133,846 & $(1,635)$ & 132,211 \\
\hline 16 & 43,591 & 525 & 877 & 16 & 84 & 502 & 1,031 & 4 & 57 & 178,406 & 1,093 & 179,499 \\
\hline 17 & 24,274 & 538 & 1,899 & 174 & 104 & 1.521 & 1,744 & 75 & 370 & 61,084 & 18,893 & 79,976 \\
\hline 18 & 12,644 & 659 & 347 & 70 & 123 & 754 & 2,212 & 34 & 1,284 & 87.195 & 143.871 & 231.066 \\
\hline 19 & 1.715 & 2,982 & 653 & 8 & 1,262 & 489 & 529 & 37 & 515 & 22,623 & 43,653 & 66,277 \\
\hline 20 & 10.429 & 511 & 810 & 137 & 104 & 667 & 1,667 & 22 & 112 & 50,166 & 48,287 & 98,453 \\
\hline 21 & 280 & 255 & 302 & 5 & 57 & 90 & 1.807 & 17 & 114 & 23,470 & 41,090 & 64,260 \\
\hline 22 & 790 & 99 & 68 & 0 & 26 & 49 & 1.472 & 3 & 7 & 6,907 & 6,118 & 13,025 \\
\hline 23 & 944 & 169 & 266 & 10 & 33 & 78 & 207 & 6 & 88 & 9.944 & 21.327 & 23,270 \\
\hline 24 & 2.478 & 610 & 9.810 & 25 & 19 & 1,089 & 603 & 11 & 486 & 17,243 & 62 & 17,305 \\
\hline 25 & 0 & 0 & 0 & 0 & 0 & 0 & 0 & 0 & 0 & . $\quad 0$ & 401,558 & 401,558 \\
\hline 26 & 9,748 & 788 & 968 & 998 & 227 & 1.146 & 5,103 & 767 & 2.670 & 71.958 & 40.727 & 112,685 \\
\hline 27 & 13.359 & 1,985 & 3.245 & 2.857 & 361 & 1,515 & 5,514 & 77 & 859 & 125.265 & 45,174 & 170,439 \\
\hline 28 & 0 & 0 & 0 & 0 & 0 & 0 & 0 & 0 & 0 & 0 & 46.755 & 46.755 \\
\hline 29 & 299 & 220 & 931 & 6 & 53 & 267 & 3.393 & 212 & 2.213 & 19.775 & 13,444 & 25,219 \\
\hline 30 & 384 & 328 & 1.326 & 7 & 83 & 336 & 8,265 & 935 & 2,987 & 21,783 & 73,002 & 94,785 \\
\hline 31 & 759 & 5,864 & 2.320 & 56 & 1.671 & 1.230 & 7,575 & 748 & 2.696 & 39,821 & 152,787 & 192,608 \\
\hline 32 & 1,243 & 598 & 32.178 & 85 & 76 & 737 & 548 & 975 & 100 & 76,977 & 1,644 & 78,621 \\
\hline \multirow[t]{2}{*}{33} & 0 & 0 & 0 & 0 & 0 & 0 & 0 & 0 & 0 & 0 & 62.583 & 62,583 \\
\hline & 267,964 & 38,021 & 76,663 & 33,414 & 8,513 & 25,100 & 96,270 & 4,590 & 21,314 & $2,204,332$ & $2,035,483$ & $4,239,815$ \\
\hline
\end{tabular}

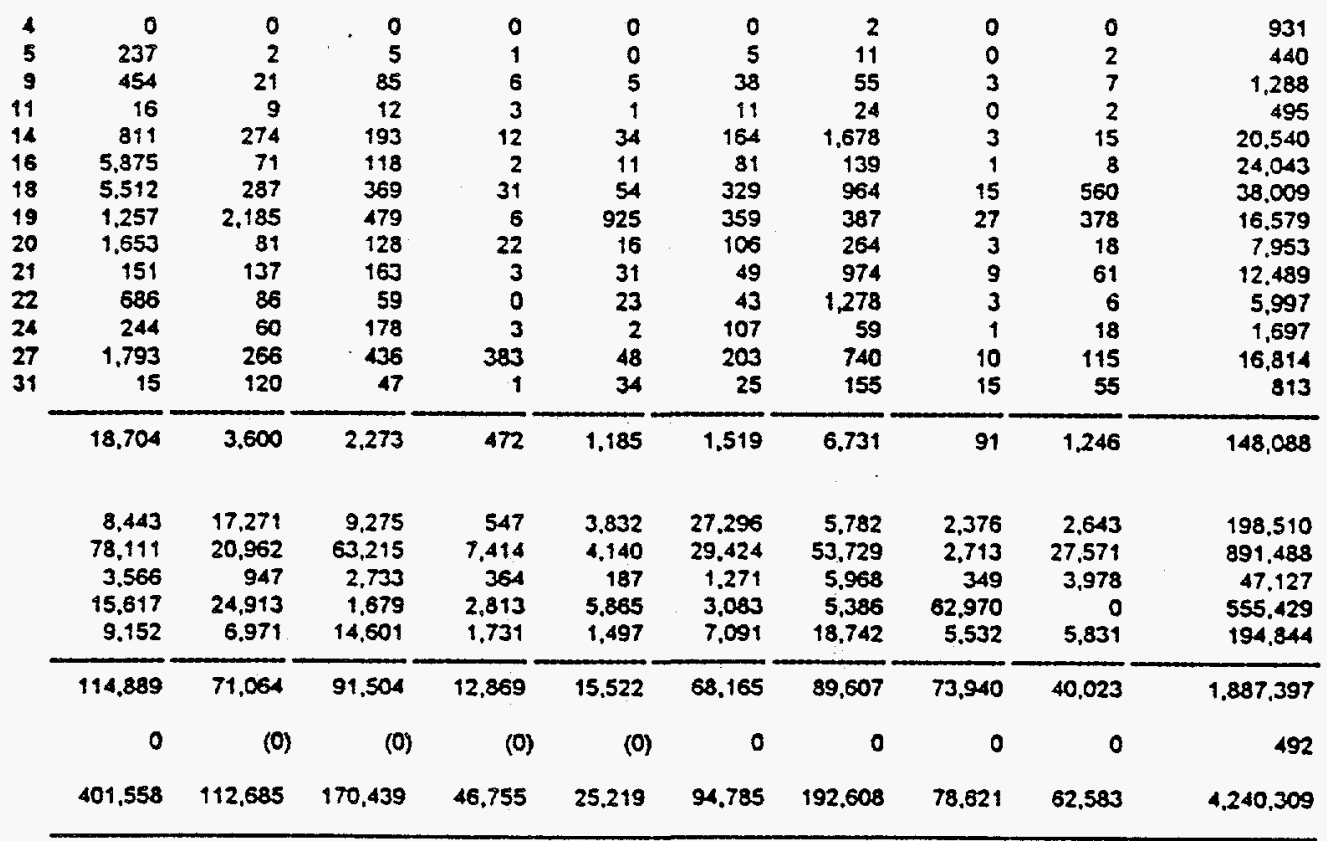


to reduce $\mathrm{CO}_{2}$ emissions. The I-O table identifies the fossil fuel mix of the electricity services sector. Column 11 shows purchases of 11,450 million yuan of coal and 2,477 million yuan of petroleum and natural gas (the latter fuels are more finely disaggregated during the computations).

In general, the I-O table presents a snapshot of the economy at any time. It readily depicts the relative sophistication, interdependence, and self-sufficiency of the economy. These characteristics can be identified by the analysis of the size of the individual cells of the table, the relative prominence of various sectors, and the composition of domestic and imported inputs on a sector-by-sector basis. 


\section{THE BASIC STRUCTURE OF CHINA'S DYNAMIC LINEAR PROGRAMMING MODEL}

\subsection{INTRODUCTION}

This section presents the multisector growth model that serves as the basis for the analysis. The emphasis is purely on economics. Section 5 discusses pollution emissions, technological changes, and related policies.

The framework is that of the DLP model. The data core of the model is the I-O transactions table for China. Unlike a simple I-O model, which requires an exogenous specification of final demand and then calculates sectoral gross outputs required to meet it based on fixed production requirements but infinite supply elasticities, the DLP formulation incorporates a range of capabilities:

- An optimizing capability in the model to pursue an objective such as maximizing economic growth. This capability also imparts choice into the model and allows for various substitutions between elements of consumption, between elements of final demand in general (consumption vs. investment), and between domestic and imported goods.

- Explicit constraints that reflect resource supply limitations.

- Policy constraints that relate to trade, environmental pollution, or population growth.

- Changing coefficients over time to represent changes in technology, consumption patterns, and factor productivity.

- The ability to project the time path of the economy (economic growth) on the basis of alternative assumptions that relate to population growth, factor productivity improvements, outside aid, and a range of policy variables.

The basic linear programming (LP) problem can be expressed as follows:

$$
\max \sum_{j=1}^{n} v_{j} X_{j}
$$

subject to:

$$
\sum_{j=1}^{n} a_{i j} X_{j} \leq b_{i} \quad(i=1 \ldots, m)
$$


and

$$
X_{j} \geq 0 \quad(j=1 \ldots, n)
$$

where

$$
\begin{aligned}
v_{j} & =\text { unit value of activity (output) } j \\
X_{j} & =\text { total gross output of sector } i \\
a_{i j} & =\text { input of good } i \text { per unit of output of good } j ; \text { and } \\
b_{i} & =\text { maximum available quantity of input } i .
\end{aligned}
$$

The other variables were defined previously.

This version of an LP problem is referred to as the primal and has associated with it a dual, which is its obverse image. The optimization goal, direction of inequalities (except Equation 3c), and number of equations and unknowns are opposites in the two versions. The standard economic interpretation is to have the primal identify activity levels that maximize the value of output, while the dual assigns values (efficiency, or shadow, prices given by the dual) to the inputs to minimize production costs. For example, Section 6 calculates the shadow price of a $\mathrm{CO}_{2}$ emission constraint.

The most basic reformulation of the problem at the macro level involves taking a basic I-O model and maximizing final demand (gross national product [GNP]) subject to supply constraints. This "choice on the demand-side" problem requires modification of Equations (3a)-(3c) as follows:

1. Change the objective function to maximize the value of final demand, $\Sigma p_{j} Y_{j}$, where $p_{j}$ is the price of good $j$, and $Y_{j}$ is the quantity of final demand for good $j$. Note that by the standard accounting identity:

$$
\sum_{j=1}^{n} v_{j} X_{j} \equiv \sum_{j=1}^{n} p_{j} Y_{j}
$$

where the former term denotes total value added.

2. Add an I-O balance constraint (recall the previous section):

$$
X_{i}-\sum_{j=1}^{n} a_{i j} X_{j}=Y_{i} \quad(i=1 \ldots, n)
$$


3. Add explicit constraints for primary factors of production.

4. Add constraints for other key variables in the model, such as minimum consumption requirements maximum export levels, etc.

The "choice on the supply-side" problem enables analysis of the optimal mix of alternative technologies within each sector, plus the choice of imported goods or domestic substitutes.

\subsection{BASIC MODEL}

This model is a modification of the Dervis et al. (1982) model. Similar models are presented in Bruno et al. (1970) and Taylor (1978). The model will be run for three periods: 1990-2000, 2000-2010, and 2010-2025. Therefore, it is structured to embody long-run assumptions, such as perfect mobility of both labor and capital between sectors over the four stages of the forecast period.

An equation-by-equation presentation of the model is presented below.

\section{a. Objective Function:}

$$
\max \sum_{t=1}^{T} \sum_{i=1}^{n}\left(\frac{1}{1+\rho}\right)^{t} Y_{i}^{t}
$$

where

$$
\begin{aligned}
Y_{i}= & \text { final demand for the products of sector } i\left(A C_{i}+T A_{i}+E_{i}-M_{i}\right) ; \\
A C_{i}= & \text { aggregate consumption of good } i \text { (household and institutional } \\
& \text { consumption); } \\
T A_{i}= & \text { total accumulation of good } i \text { (net and replacement investment); } \\
E_{i}= & \text { exports of good } i ; \\
M_{i}= & \text { imports of good } i ; \text { and } \\
\rho= & \text { discount rate. }
\end{aligned}
$$

The program maximizes the discounted value of final demand (GNP) over the forecast period. The final demand is composed of the usual aggregate demand categories. However, in China, aggregate consumption includes both household and institutional (government) consumption. In addition, accumulation includes both investment and inventory change. 
b. Interindustry Constraint:

$$
X_{i}^{t}-\sum_{j=1}^{n} a_{i j} X_{j}^{t}=Y_{i}^{t} \quad(i=1 \ldots, n),
$$

where $a_{i j}$ are technical coefficients.

Equation $5 \mathrm{~b}$ is the I-O balance equation presented earlier. It embodies the technological possibilities in the economy and requires that the total supply of each good or service equals the total demand.

c. Factor Constraints:

$$
\sum_{j=1}^{n} k_{j}^{t} X_{j}^{t} \leq \bar{K} \quad \sum_{j=1}^{n} l_{j}^{t} X_{j}^{t} \leq \bar{L}
$$

where

$$
\begin{aligned}
& \bar{K}=\text { total capital stock (in terms of money value); } \\
& \bar{L}=\text { total labor supply (in terms of money value); } \\
& k_{j}=\text { capital-output ratio in sector } j \text {, and } \\
& l_{j}=\text { labor-output ratio in sector } j .
\end{aligned}
$$

Equations 5a-5c relate to the stock and availability of primary factors of production. Because of the difficulty of obtaining capital stock estimates by type (i.e., by sector of origin), the equations depend on capital utilization (depreciation) coefficients from China's 1987 I-O table for the preliminary runs. Labor coefficients are used in an analogous manner as a proxy for sectoral employment levels.

Given the 10- to 15-year milestone dates during the projection period, perfect capital and labor mobility are assumed. For labor, this assumption means that no impediments exist to transferring this factor between sectors; i.e., the necessary training can readily be accomplished within 10 years to accommodate the relatively modest changes in the sectoral mix projected over time. In a similar manner, capital can be modified, or it can be safely assumed that the 10- to 15-year period allows for sufficient time for ordinary replacement of most equipment so that it can readily be "transferred" to new sectors.

The total labor and capital requirements can be set equal to their utilization levels in a given year if full employment and full capacity utilization are assumed. Alternatively, excess labor and capital can be incorporated into the analysis to depict more realistic situations.

One aspect of the labor supply inequality should be noted. If economic growth is $8.5 \%$ per year, but population grows at only $1.5 \%$ per year, there would appear to be an 
inconsistency. (For completeness, Section 4.3 presents a method to calculate and relate different rates of economic growth and anticipate some results.) In a world in which labor remuneration is allowed to rise, but capital rates do not, capital stock should grow at the same rate as the wage bill (labor force increase plus labor remuneration) because of the constant factor shares property of the Cobb-Douglas production function. The growth in both factors is combined such that the difference between the rate of growth of gross output and the rate of growth of population is the rate of growth of labor remuneration affected by a multiplicative factor that is precisely the Cobb-Douglas coefficient for capital. The increase in the wage bill can result from a combination of economic phenomena, including increased labor force participation rates, decreased unemployment, and increased labor productivity. One advantage of this model is that it does not require any restrictive assumptions pertaining to any of these considerations.

d. Consumption Constraint:

$$
\underline{b}(1+\gamma) A C_{i}^{t-1} \leq A C_{i}^{t} \leq \bar{b}(1+\gamma) A C_{i}^{t-1} \quad(i=1 \ldots, n),
$$

where

$\underline{b}=$ lower bound;

$\gamma=$ rate of economic growth; and

$\bar{b}=$ upper bound.

This constraint is necessary to ensure that basic human needs are met, while other adjustments are made in the final demand to maximize economic growth. (Various changes in consumption patterns can be accommodated at a later date to account for shifts in preferences as income increases [i.e., nonlinear Engel curves].) Upper bounds are included to avoid overspecialization or unreasonable shifts in tastes.

Aggregate consumption in China includes both household and institutional (government) consumption. Large amounts of government expenditures are assumed to provide basic services such as health and education and therefore require lower bounds, as do private consumption goods. Also, this constraint applied to institutional consumption would call for military expenditures being a constant proportion of the GNP.

e. Investment, or Capital Updating, Equation:

$$
K_{i}^{t+1}=K_{i}^{t}\left(1-d_{i}^{t}\right)+T A_{i}^{t} \quad(i=1 \ldots, n),
$$

where $d_{i}^{t}$ is the depreciation rate. 


\section{$\mathrm{e}^{\prime}$. Alternative Investment Equation:}

$$
T A_{i}^{t}=K_{i}^{t+1}-K_{i}^{t}
$$

The basic investment equation includes two terms that stipulate that investment in a given good (equipment type) equals the sum of replacement and gross investment. To simplify the initial runs, abstract from the replacement investment consideration; i.e., assume depreciation is zero. This step reduces the investment requirement but makes the model more tractable. These simulations are structured to follow a target growth rate, and, therefore, this simplification does not bias the model results, except that it shifts from investment goods toward export goods.

\section{f. Foreign Exchange Constraint:}

Foreign exchange earned by exports plus the net foreign capital inflow provide the upper bound on imports. In this model, the bound is imposed at the aggregate level. The sum of imports is thus less than the sum of both exports of all sectors and net foreign capital inflow. Net foreign capital inflows depend on the forecast of the future trade at a fixed growth rate over the period:

$$
E R^{t} \sum_{i=1}^{n} M_{i}^{t}=E R^{t} \sum_{i=1}^{n} E X_{i}^{t}+F K^{t} \text {, }
$$

where $E R^{t}$ is the exchange rate, and $F K^{t}$ is the net foreign capital inflow.

\section{f. Alternative Foreign Exchange Constraint:}

In this case, net foreign capital inflow is a percentage of trade or the previous level of foreign capital inflow.

g. Import Equation:

$$
m_{i} X_{i}^{t}=M_{i}^{t} \quad i=(1 \ldots, n)
$$

where $m_{i}$ is the import-output coefficient. Equation $5 \mathrm{~g}$ stipulates fixed import requirements per unit of output. Unfortunately, it thus presents a rather static picture of trade. Ways are being explored to incorporate import substitution that usually accompanies industrial development. For example, China would be expected to import increasingly lower proportions of advanced machinery and equipment over time. 


\section{h. Export Constraint:}

$$
\underline{b}(1+\gamma) E_{i}^{t-1} \leq E_{i}^{t} \leq \bar{b}(1+\gamma) E_{i}^{t}-1
$$

These sets of equations place upper and lower bounds on exports. Lower bounds are needed to avoid "flip-flop" solutions, or overspecializations, typical in linear models, but that represent too great a departure from reality. Upper bounds are placed on exports for similar reasons. (This study strictly limits exports of services because of physical limitations on their role in international trade.) These bounds place China somewhere in between the "small country" case (able to export as much as it wants without affecting world prices) and the "big country" case (export levels are limited and do affect world prices).

\subsection{CONSISTENT CALCULATION OF GROWTH RATES}

The model presented here is a multiperiod optimizing model that requires a periodby-period specification of the constraint levels for factors (capital and labor) and an upper bound for total output (Equations $5 \mathrm{c}$ and $5 \mathrm{e}$ ). Those bounds are set by expanding the corresponding baseline figures with growth factors, calculated by adapting Almon's (1963) approach of consistent forecasts, whose relevant characteristics are explained below.

Almon uses a dynamic I-O model to forecast growth in a full-employment economy. No overall optimization of the economy is attempted. He assumes that each sector minimizes the costs of capital and labor services of producing output with a Cobb-Douglas production function.

Coefficient $\underline{b}$ in Equation (5d) is set at 0.75 (a minimum consumption level of domestically produced goods at the starting year), and coefficient $\bar{b}$ in the same equation is set at 1.5 to allow for some sector specialization beyond the overall (target) growth of final demand. Once the overall growth rate in final demand is set, iterations with different wage bills are required to obtain that value. By fixing the rate of population growth, all possible increases in final demand growth are driven by increases in the wage bill, which in turn force the capital stock to rise. The consistent set of parameters that attains the target GNP growth rates is presented in Table 13 . The value obtained for $\underline{K}$ is close to observed annual increases of capital in China's economy. Wages are allowed to grow over time at the same rate in each sector, but the rental value of capital is fixed and is the same for each sector. The implication is that only substitution between capital and labor is present, driven by increases in wages, and that the capital/labor combination is complementary to any other input.

Almon's basic model does not allow for factor productivity growth, but it is straightforward to obtain. The idea is to find the minimum cost of producing a given output level with a Cobb-Douglas production function whose factors are only capital and labor. The first-

order conditions are a set of relations between capital and labor for a static picture of the 
TABLE 13 China DLP Simulation Model Economic Parameters

\begin{tabular}{|c|c|c|}
\hline \multirow[b]{2}{*}{ Parameter/Time Period } & \multicolumn{2}{|c|}{ Value } \\
\hline & $\begin{array}{c}\text { Lower Bound } \\
(\%)\end{array}$ & $\begin{array}{c}\text { Upper Bound } \\
(\%)\end{array}$ \\
\hline \multicolumn{3}{|l|}{ GNP growth ${ }^{a}$} \\
\hline $1990-2000$ & 6 & 8.5 \\
\hline $2000-2010$ & 4 & 7.5 \\
\hline $2010-2025$ & 3 & 6.5 \\
\hline \multicolumn{3}{|l|}{ Population growth ${ }^{\mathrm{a}}$} \\
\hline $1990-2000$ & $b$ & 1.5 \\
\hline $2000-2010$ & b & 1.2 \\
\hline $2010-2025$ & b & 0.9 \\
\hline \multicolumn{3}{|l|}{ Wage bill growth ${ }^{a}$} \\
\hline $1990-2000$ & 8.23 & 13.22 \\
\hline $2000-2010$ & 5.60 & 12.60 \\
\hline $2010-2025$ & 4.20 & 11.20 \\
\hline \multicolumn{3}{|l|}{ Capital bill growth ${ }^{\mathbf{a}}$} \\
\hline $1990-2000$ & 9.73 & 14.72 \\
\hline $2000-2010$ & 6.80 & 13.80 \\
\hline $2010-2025$ & 5.10 & 12.10 \\
\hline \multicolumn{3}{|l|}{ Gross output growth ${ }^{a}$} \\
\hline $1990-2000$ & 5.62 & 8.11 \\
\hline $2000-2010$ & 4.00 & 7.50 \\
\hline $2010-2025$ & 3.00 & 6.50 \\
\hline \multicolumn{3}{|l|}{ Discount rate } \\
\hline All periods & 4 & 8 \\
\hline \multicolumn{3}{|l|}{ Depreciation rate } \\
\hline All periods & 5 & 6.7 \\
\hline \multicolumn{3}{|l|}{ Exchange rate } \\
\hline All periods & 4.73 & 4.73 \\
\hline \multicolumn{3}{|l|}{ Trade balance } \\
\hline All periods & 0 & 0 \\
\hline $\begin{array}{l}\text { Capital constraint } \\
\quad 1990\end{array}$ & $\mathbf{b}$ & $(2.8579) 10^{12}$ yuan \\
\hline $\begin{array}{l}\text { Labor constraint } \\
\quad 1990\end{array}$ & b & (1.0324) $10^{12}$ yuan \\
\hline
\end{tabular}

a Annual rate, endogenous.

b Same as upper bound. 
economy. To introduce temporal features, these first-order conditions are converted into growth rates. ${ }^{3}$ Optimality relations in levels become optimality conditions for rates of growth. Consistency is provided to the forecast both dynamically (because growth rates of factors and output are mutually determined within a cost-minimizing scheme) and intersectorally (because each sector output is determined by I-O interconnections).

Almon's idea of factor cost minimization is adapted in this report, but for the economy as a whole, not sector by sector. All that is required is a meaningful way to shift the bounds on factors over time and to find the corresponding gross output growth, allowing for factor mobility. A less-aggregated version can be formulated if some sectors are to be studied in more detail. The optimization approach translates factor mobility into improved sector allocation and value of final demand. The consistency of Almon's model is embedded in the model presented here; however, this model optimizes (to achieve a target growth rate) rather than forecasts. Also, the model is extended to incorporate factor productivity growth.

The relationship among rates of growth of factors (again "growth" differentiating the first-order conditions) is

$$
\hat{K}=\hat{N}+\hat{W}
$$

where

$$
\begin{aligned}
\hat{K}= & \text { rate of growth of capital (capital stock minus capital productivity } \\
\text { growth); } & \\
\hat{N}= & \text { rate of growth of labor (population minus labor productivity growth); } \\
& \text { and } \\
\hat{W}= & \text { rate of growth of wages. }
\end{aligned}
$$

Also, the relationship among overall rates of growth in output is

$$
\hat{X}=\hat{K}-a \hat{W}
$$

where $\hat{X}$ is the rate of growth of gross output, and $a$ is the Cobb-Douglas coefficient for labor stock for the overall economy. A simultaneous specification of labor productivity growth and increased wages might lead to an unemployment outcome (unless the model is constrained).

3 That is, $\hat{K}^{t}=\frac{d K^{t} / d t}{K^{t}}=\frac{K^{t}}{K^{t}}$. 
Using exogenous estimates of $\hat{N}$ and $\hat{W}$ (Table 13) allows endogenous computation of the rate of growth of capital $\hat{K}$ by means of Equation (6a). The rate of growth of the total gross output $\hat{X}$ is then calculated by using Equation (6b). These values set upper bounds on factor availability and total gross output at each time period. The rate of growth of (total) final demand is then endogenously found by the optimization procedure.

Because the model focuses only on production-side relations, it requires judgments about the long-term behavior of final demand components and iterations to make results and constraints compatible with a target in final demand growth $\hat{Y}$. Fixing $\hat{N}$ implies that iterations with different values of $\hat{W}$ might be necessary to obtain this target.

Two additional modifications are made to the previous equation set to incorporate the results of Equations (6a) and (6b).

\section{i. Final Demand Constraint:}

$$
\underline{b}(1+\gamma) Y_{i}^{t-1} \leq Y_{i}^{t} \leq \bar{b}(1+\gamma) Y_{i}^{t-1} \quad(i=1 \ldots, n)
$$

where $\gamma$ is the rate of growth of overall final demand $(\gamma \equiv \hat{Y})$.

Equation $5 i$ is a variant of constraint (3d) and allows greater flexibility in using the model. The lower bound is necessary to ensure minimum final demand levels of domestically produced commodities, and the upper bound is necessary to avoid overspecialization or unreasonable shifts in tastes.

j. Overall Gross Output Growth Constraint:

$$
\sum_{i=1}^{n} X_{i}^{t} \leq \sum_{i=1}^{n} \bar{X}_{i}^{t} \quad(i=1 \ldots, n)
$$

Growth in total gross output is bounded to achieve the GNP growth targets. ${ }^{4}$

\subsection{MODEL PARAMETERS}

The parameters noted in Section 4.3, as well as those associated with economic activity, are listed in Table 13. Most cases show distinct lower- (low numerical value) and upper- (high numerical value) bound values. Several key parameters such as economic growth and population growth have been specified in collaboration with the contracting agency and Argonne National Laboratory (ANL) staff, and with reference to the East-West Center (EWC)/ANL (1994) report (Asian Development Bank [ADB] 1994).

4 In the economic-environmental simulations, the model is run to determine deviations from these targets. 
agency and Argonne National Laboratory (ANL) staff, and with reference to the East-West Center (EWC)/ANL (1994) report (Asian Development Bank [ADB] 1994).

Briefly, during the past few years, China's economy has undergone phenomenal growth (i.e., in the range of 8-12\%). On the basis of the experiences of other countries, the upper-bound growth rate assumes this pace can continue for a number of years, but that it must decline as the more obvious opportunities for development are exhausted. The lowerbound estimate would reflect conditions of domestic strife or difficulty in the transition of certain sectors to a greater market orientation.

The population projection is based on the upper-bound population projection offered in EWC/ANL (1994). The lower bounds from the source appear somewhat tenuous, with the specification of a population growth of only $0.1 \%$ by year 2050 , so they have been ignored.

The balance of trade is assumed to be zero. It has vacillated between slightly positive and slightly negative over the past several years. The assumed value is chosen for lack of a more definitive projection on this score and does not greatly affect the analysis.

Several other key parameters are used in simulating the macroeconomic impacts of environmental policies that affect China's coal industry. These parameters include the rate of autonomous energy efficiency improvement (AEEI) (conservation), the stringency of pollution reduction requirements, fossil fuel reserve estimates, and the availability of new energy technologies.

\subsection{BASELINE PROJECTION}

This section tests the model and uses it to make baseline projections of the time path of China's economy and its pollution emissions. These projections are presented in Tables 14 and 15 for upper- and lower-bound parameter sets, respectively. The model is verified by comparing a simulation generated by it with China's projected 1990 I-O table. The two estimates are likely to differ because the model used here has optimizing features, while the I-O representation of the economy does not. One would expect that optimizing final demand (GNP), even under the rather tight constraints on the reallocation of consumption and exports, would exceed the actual final demand figures in the 1990 I-O table. This assumption is true because the results of the upper-bound projections are presented in columns 4 and 5 of Table 14 and can be compared with the baseline I-O numbers presented in columns 1 and 2. Baseline GNP is 18.9 billion yuan, while the optimizing model estimate is 20.8 billion yuan, a deviation of $10.2 \%$. However, the total gross output figures are the same between the baseline and the 1990 estimate, although differences are evident at the sectoral level.

On a sector-by-sector basis, the gross output estimates in this report and the I-O projections are very close (compare individual entries in columns 2 and 5). For example, no sectors show estimates that differ by more than 20\%; in most cases, they differ by less than $5.0 \%$. The results for final demand are much more disparate. Most of the sectoral levels are at either their upper bound ( 1.2 times the baseline) or lower bound ( 0.8 times the baseline) 
TABLE 14 Baseline Projections - Upper Bound

1 Agniculture

3 Coul mulining

3 Cruda pelioledin

5 Metsl vid numing

- Food manulacluting

Manufacture of lextites

Monulactute ol apparel

Sammills and manulacture of furniture

Manulacture of paper and educ maleria

2 Petroleun refineties

13 Coknng. manulaciure of gas 8 caal

14 Chemical industnes

is Manufacture of budding materials

16 Pnimary melda manulacluring

18 Manulacture of machinery

18 Manulacturte of machinery

21. Manulaclure of electronics equip

22 Manutacture of instruments

23 Maintenance and repair of macninery

24 Industnes nol

26 Freignt transport and communication

27 Commerce

Passenger lranspon

Public ulliles and services to house

Final

DLP

BASE

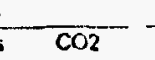

Finat

CO2

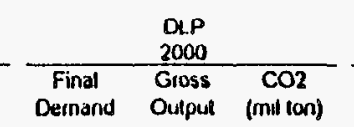

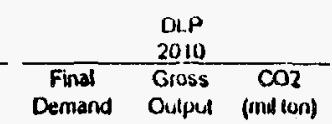

Final $G$

OLP

$\mathrm{CO}$
$\mathrm{COSO}$

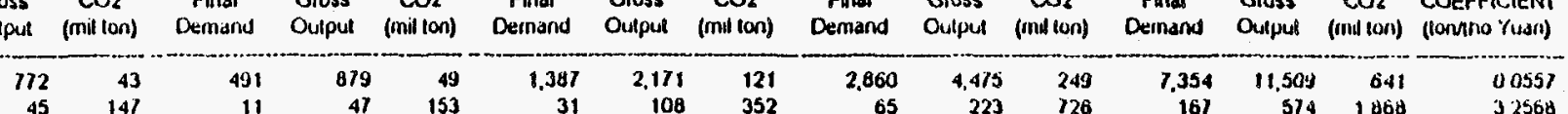

$\begin{array}{rrr}9 & 45 & 43 \\ 7 & 44 & 9\end{array}$

(1) 15

$\begin{array}{rr}304 & 305 \\ 99 & 275\end{array}$

$\begin{array}{rr}58 & 77 \\ 7 & 36\end{array}$

$25 \quad 110$

6
2
3

310

$\begin{array}{rrr}21 & 300 & 186 \\ 2 & 132 & 180\end{array}$

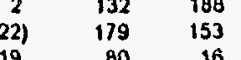

$27 \quad 231$

$\begin{array}{ll}27 & 66 \\ 40 & 98\end{array}$

$\begin{array}{ll}31 & 64 \\ \text { (1) } & 13 \\ 21 & 23\end{array}$

(1) 17

$\begin{array}{rr}402 & 402 \\ 41 & 113\end{array}$

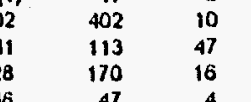

$\begin{array}{rrr}46 & 47 & 16\end{array}$

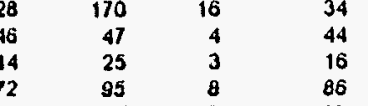

$\begin{array}{rrrrrr}95 & 8 & 86 & 29 & 3 \\ & 95 & 110 & 10\end{array}$

$\begin{array}{rrrrrr}2 & 193 & 17 & 183 & 226 & 20 \\ & 79 & 7 & 2 & 75 & 8\end{array}$

$\frac{63}{63}-63 \quad 5$

2.080

$2 4 0 \longdiv { 1 , 6 2 0 }$ $\begin{array}{rr}108 & 352 \\ 109 & 23\end{array}$

$\begin{array}{ll}0 & 28 \\ 0 & 67\end{array}$

98
12

42

19
7

7
5
36
6

6

$\begin{array}{rr}0 & 311 \\ 32 & 140\end{array}$

$\begin{array}{rr}32 & 148 \\ 174 & 331\end{array}$

$46 \quad 92 \quad 40$

$\begin{array}{ll}69 & 159 \\ 78 & 125\end{array}$

$\begin{array}{rr}0 & 14 \\ 72 & 77\end{array}$

$29 \quad 69$

138

96

79
46

46.
48

$\begin{array}{rr}46 & 78 \\ 244 & 305\end{array}$

518.620

$\begin{array}{ll}212 & 161 \\ 212\end{array}$

4.704

\begin{tabular}{|c|c|c|c|c|c|c|}
\hline & & & & & & \\
\hline 65 & 223 & 226 & 167 & 574 & 1,860 & 32568 \\
\hline 52 & 224 & 48 & 134 & $5 / 7$ & 124 & $021+1$ \\
\hline 0 & 57 & 0 & o & $1+6$ & D & 00000 \\
\hline 1 & 134 & 0 & 2 & 355 & 0 & 00000 \\
\hline 713 & 1.157 & 237 & 1.833 & 2.975 & 608 & 02045 \\
\hline 346 & 1,035 & 167 & 890 & 2,663 & 430 & 01615 \\
\hline 203 & 278 & 0 & 522 & 714 & 0 & 00000 \\
\hline 25 & 135 & 0 & 63 & 346 & 0 & 0.0000 \\
\hline 87 & 480 & 134 & 223 & 1.235 & 346 & 02799 \\
\hline 39 & 292 & 2,278 & 101 & 750 & 5,859 & 18111 \\
\hline 14 & 290 & 189 & 37 & 745 & 480 & 06523 \\
\hline 10 & 38 & 317 & 25 & 97 & 816 & 84178 \\
\hline 74 & 1.270 & 704 & 190 & 3,266 & 1.810 & 0.5543 \\
\hline 12 & 516 & 733 & 31 & 1.327 & 1.884 & 1.4199 \\
\hline 0 & 641 & 547 & 0 & 1,648 & 1.400 & 08542 \\
\hline 66 & 305 & 59 & 169 & 784 & 152 & 01941 \\
\hline 359 & 683 & 83 & 924 & 1,757 & 214 & 0.1211 \\
\hline 94 & 190 & 23 & 242 & 489 & 60 & 0.1218 \\
\hline 141 & 327 & 40 & 363 & 841 & 102 & 01218 \\
\hline 161 & 257 & 31 & 414 & 662 & 81 & 0.1218 \\
\hline 0 & 30 & 0 & 0 & 76 & 0 & 00000 \\
\hline 149 & 159 & 0 & 384 & 408 & 0 & 00000 \\
\hline 60 & 143 & 0 & 156 & 367 & 0 & 0.0000 \\
\hline 1.403 & 1.403 & 35 & 3,609 & 3,609 & 90 & 00250 \\
\hline 285 & 602 & 251 & 732 & 1,549 & 644 & 04161 \\
\hline 198 & 715 & 66 & 510 & 1.838 & 169 & 00921 \\
\hline 163 & 163 & 15 & 418 & 418 & 39 & 0.0921 \\
\hline 95 & 160 & 18 & 245 & 412 & 47 & 0.1135 \\
\hline 504 & 628 & 54 & 1,296 & 1,614 & 140 & 0.0864 \\
\hline 1.088 & 1,278 & 110 & 2,746 & 3,286 & 284 & 0.0864 \\
\hline 12 & 331 & 29 & 30 & 851 & 74 & 0.0884 \\
\hline 437 & 437 & 38 & 1.125 & 1.125 & 97 & 00864 \\
\hline
\end{tabular}

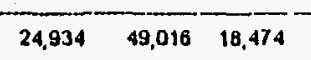

Final Demand and Gross Oulput in billions of 1990 Yuans

Final Demand(GDP) Gromin Rate

1990-2000 $850 \%$

$\begin{array}{ll}2000.2010 & 7.50 \% \\ 2010.2025 & 6.50 \%\end{array}$ 
TABLE 15 Baseline Projections - Lower Bound

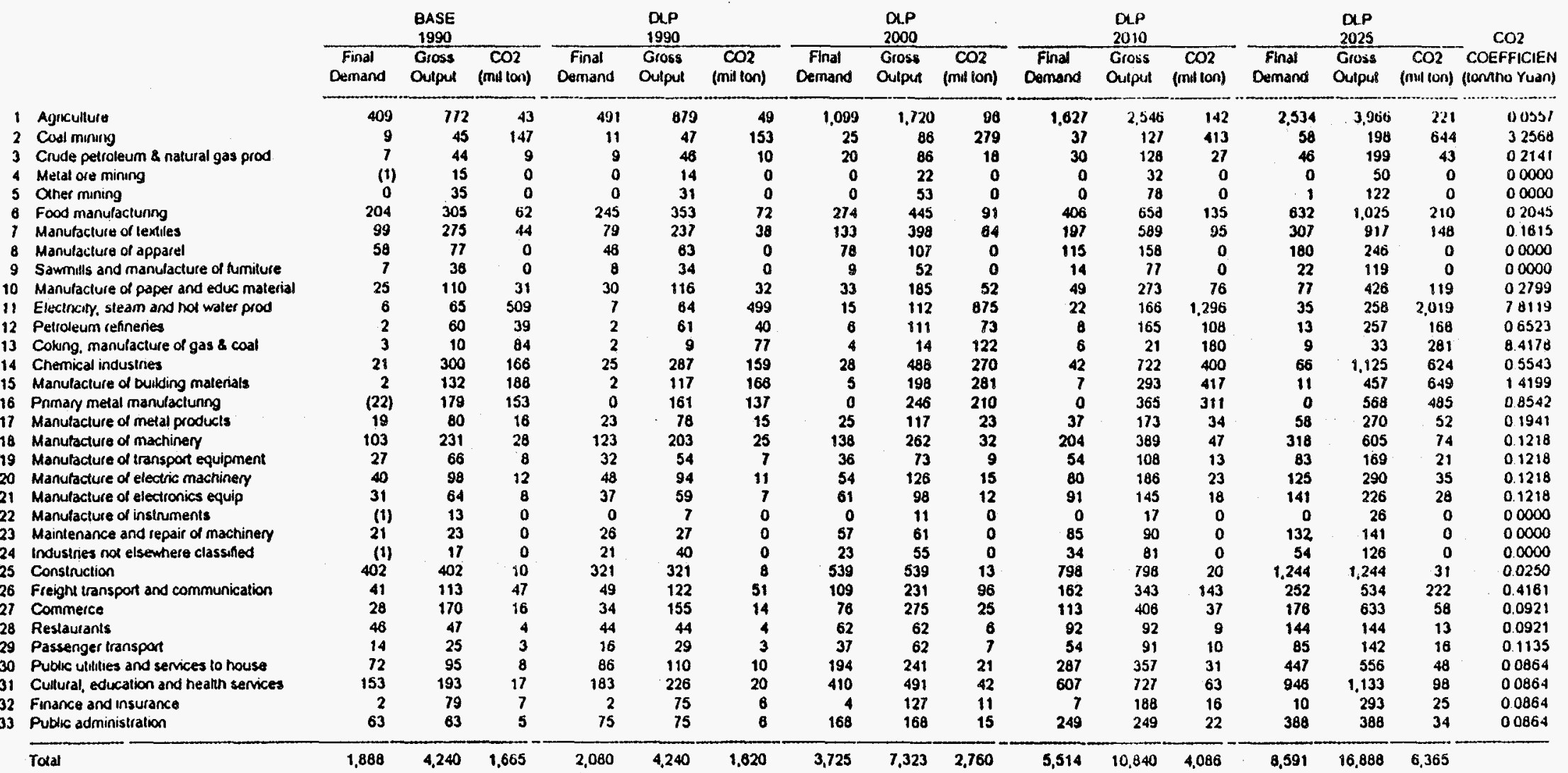

Finat Demand and Gioss Oulput in billions of 1990 Yuans

$\begin{array}{cc}\text { Firat Demand Increasing Rale } \\ 1990.2000 & 6.00 \% \\ 2000.2010 & 4.00 \% \\ 2010.2025 & 300 \%\end{array}$


values for 1990 . However, $\mathrm{CO}_{2}$ emissions are more closely connected to gross output than to final demand levels, and the $\mathrm{CO}_{2}$ projection for 1990 is only $2.7 \%$ below actual estimates.

An obvious implication of the GNP results is that China's economy is not optimizing at present. Given the underlying valuation system of a planned economy (the labor theory of value) and the unwieldy nature of economic planning in such a large country, this implication would not be surprising. However, some of the difference may be due to errors in the model presented here. Still, the rather minor deviation between the I-O estimate and the LP projection means that this model is likely to offer reasonable forecasts of the timepath of China's economy.

Moreover, use of this optimizing model to make projections over time is justified because China's economy will tend more toward optimization as it becomes further integrated into the world economy and makes the transition to market orientation at home. From a pragmatic standpoint, the model projections are likely to be more realistic with a multisector model based on a DLP format than with an I-O model. The former allows for reallocations and major shifts over time, while the latter simply yields linear projections.

Initial forecasts of economic output and $\mathrm{CO}_{2}$ emissions for China's economy in the year 2000 are presented in columns 7-9. Overall, the final demand (GNP) level is projected to be 4,704 billion yuan in 2000 (a $126.1 \%$ increase over baseline); the gross output level is projected to be 9,247 million yuan (a $118.1 \%$ increase). The final demand estimates are consistent with the exogenously specified $8.5 \%$ growth rate. Significant increases in economic activity are projected in agriculture and cultural/education/health services. Some slight decreases are also projected in the machinery sectors because, at this point in the model's development, the investment equation is inadequately specified.

Estimates of $\mathrm{CO}_{2}$ emissions are derived from the model in columns 6 and 9 (for comparison with baseline levels in column 3). Sectoral $\mathrm{CO}_{2}$ emission coefficients are presented in the final column. They represent translations of emission factors to $\mathrm{CO}_{2}$ coefficients of the model. These factors were obtained by ANL staff and are expressed in tons of $\mathrm{CO}_{2}$ per million Chinese yuan in each of the 33 sectors of the economy (Section 5 ).

The baseline estimate of $\mathrm{CO}_{2}$ emissions (column 3) is 1.665 billion tons in 1990 . Interestingly, the optimization analysis of China's economy for this base year yields an estimate of 1.620 billion tons. Thus, while the estimate of final demand is $10.2 \%$ higher than baseline (compare columns 4 and 1 in Table 14), the associated estimate of $\mathrm{CO}_{2}$ emissions is actually lower. This model projects that total $\mathrm{CO}_{2}$ emissions will increase by $115.1 \%$. The difference between total gross output growth and emissions growth is due to a change in the sectoral mix (relative proportions of sectoral outputs). It reflects the shift toward more consumer-oriented and therefore less polluting products. Also, the emission picture is likely to change dramatically once explicit constraints are inserted into the model on air pollution emissions. The results of these environmental policy simulations are presented in Section 6 .

The analogous description can be offered of the lower-bound projections of Table 15 . The projected growth rates are lower, as warranted by the parameters in Table 13. 


\section{POLLUTION EMISSIONS, ENERGY RESERVES, AND ENERGY TECHNOLOGY}

This section summarizes three major technical aspects of the model:

- Emissions of $\mathrm{CO}_{2}$ and other air pollutants such as $\mathrm{SO}_{2}$ and $\mathrm{CH}_{4}$,

- Availabilities of energy resources that generate relatively low levels of $\mathrm{CO}_{2}$ or have no direct emissions of air pollutants, and

- Technological changes relating to energy intensity, energy efficiency, and energy substitution.

Raw data are presented for each case, followed by a discussion of how they are transformed into parameters and constraints for the simulations performed in Section 6 . Because of the high degree of uncertainty relating to resource availability and energy technology, a set of optimistic (upper bound) and pessimistic (lower bound) estimates is included for these two aspects. Including both aspects allows the conduct of sensitivity analyses in Section 6.

\subsection{POLLUTION EMISSIONS}

China relies heavily on fossil fuels to supply its energy needs. Pollution results primarily due to their combustion. This report considers only air pollutants, specifically $\mathrm{CO}_{2}$, $\mathrm{CH}_{4}$, and $\mathrm{SO}_{2}$.

Pollution factors express the amount of pollutant emitted per unit of fuel consumed. The pollution factors relevant to the Chinese energy sector came from two sources. First, pollution factors for coal were obtained from ANL (1994). These factors are presented in Table 16. Second, the pollution factors for natural gas and petroleum products were taken from EWC/ANL (1994). These pollution factors (tonnes of pollutants per million yuan of output) are used to calculate emission coefficients by combining them with fuel consumption figures in each economic sector.

Direct and total emission coefficients express the relation between economic activity and air pollution in China's economy. Direct emission coefficients account only for on-site, or partial equilibrium, effects and are calculated by finding the amount of each air pollutant emitted by each sector and then dividing the figure by the corresponding sectoral output. Total emission coefficients account for a combination of direct, indirect, and induced, or general equilibrium, effects and are found by multiplying the direct emission coefficients by the Leontief Inverse matrix (total input requirements coefficients) of China's economy (Section 3).

Direct emissions and emission coefficients for coal, petroleum, and natural gas are shown in Tables 17 through 22. Tables 23 and 24 show the combined direct emissions and 


\section{TABLE 16 Pollution Factors}

\begin{tabular}{|c|c|c|c|c|c|c|c|}
\hline Fuel & Factor & $\begin{array}{c}\text { Fuel } \\
\text { Consumption/ } \\
\text { Production }\end{array}$ & $\mathrm{CH}_{4}$ & $\mathrm{CO}_{2}$ & $\begin{array}{c}\mathrm{CO}_{2} \\
\text { as Carbon }\end{array}$ & $\mathrm{SO}_{2}$ & $\begin{array}{c}\text { Nitrous } \\
\text { Oxide, } \\
\mathrm{NO}_{2} \\
\end{array}$ \\
\hline \multirow[t]{3}{*}{ Coal } & Coal production (million tonne) & $1,087.4$ & & & & & \\
\hline & Pollution emission (million tonne) & & 7.1 & 1939.3 & 528.9 & 15.8 & 8.3 \\
\hline & Coefficient (per tonne of coal) & & 0.0065137 & 1.7834284 & 0.4863896 & 0.0145669 & 0.0076329 \\
\hline \multirow[t]{3}{*}{ Natural gas } & Consumption $\left(\mathrm{bcm}^{\mathrm{a}}\right)$ & 13.4 & & & & & \\
\hline & Pollution emission (million tonne) & & & 7.8 & 0 & & \\
\hline & Coefficient (tonne per bcm of natural gas) & & 0 & 0.5821 & 0 & 0 & 0 \\
\hline \multirow[t]{3}{*}{ Petroleum } & Consumption (1,000 tons) & $199,493.0$ & & & & & \\
\hline & Pollution emission (million tonne) & & 0.05 & 72.9 & 0 & & 0.34 \\
\hline & Coefficient (per 1,000 tons of petroleum products) & & 0.0000003 & 0.0003654 & 0 & 0 & 0.0000017 \\
\hline
\end{tabular}

a $\quad$ bcm $=$ billion cubic meters.

Sources: Coal figures are calculated from ANL (1994). Natural gas and petroleum figures are extracted from EWC/ANL (1994). 
TABLE 17 Direct Emissions from Use of Coal, 1990 (million tonnes)

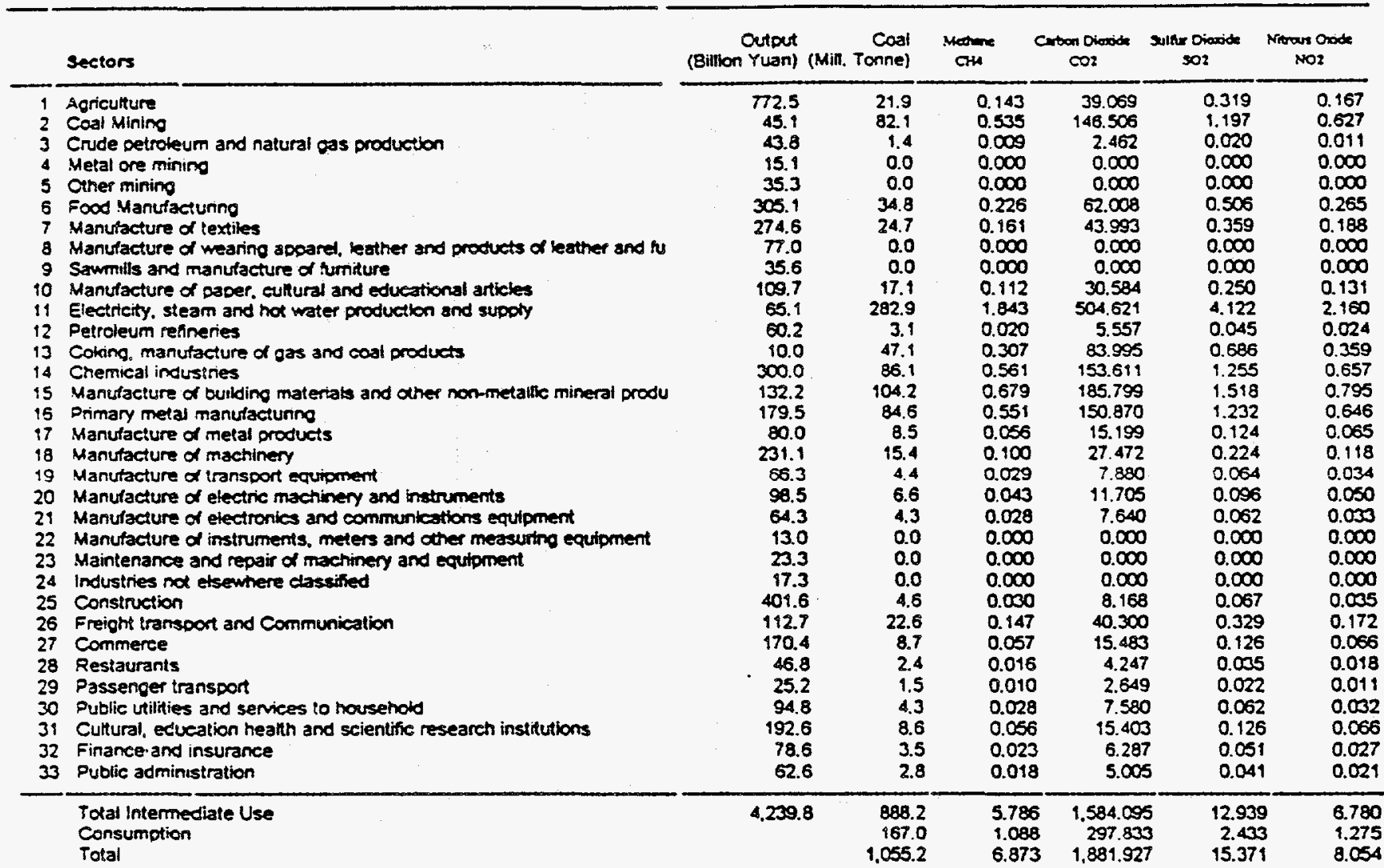

TABLE 18 Direct Emission Coefficients from Use of Coal, 1990 (tonnes per million yuan of output)

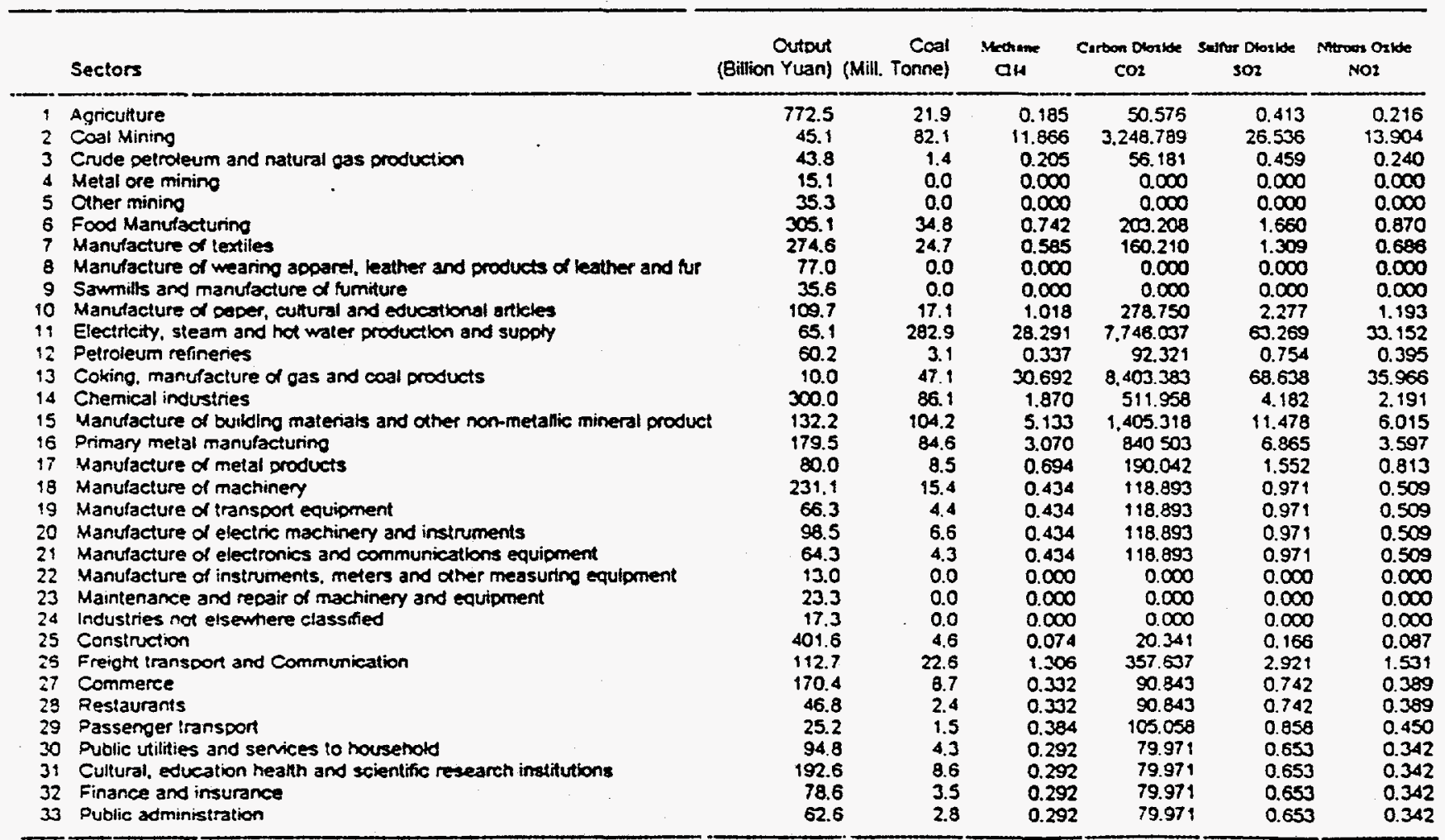


TABLE 19 Direct Emissions from Use of Natural Gas, 1990 (million tonnes)

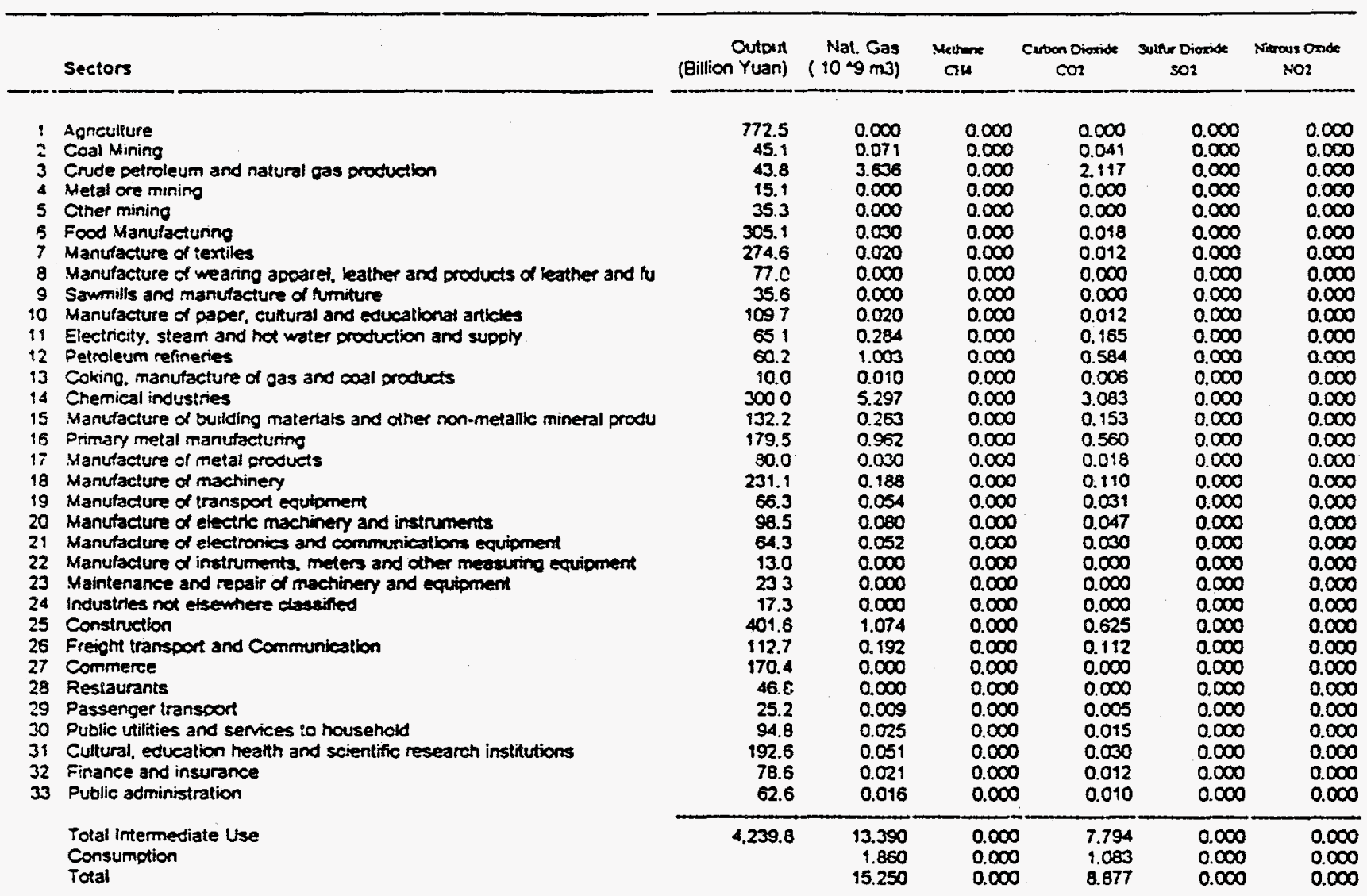

TABLE 20 Direct Emission Coefficients from Use of Natural Gas, 1990 (tonnes per million yuan of output)

\begin{tabular}{|c|c|c|c|c|c|c|c|}
\hline & Sectors & $\begin{array}{r}\text { Output } \\
\text { (Eillion Yuan) }\end{array}$ & $\begin{array}{r}\text { Nat. Gas } \\
(10 \times 9 \mathrm{~m} 3)\end{array}$ & $\begin{array}{l}\text { Metruse } \\
\text { CHA }\end{array}$ & $\begin{array}{c}\text { Cron Dioxide } \\
\mathrm{CO} 2\end{array}$ & $\begin{array}{l}\text { sultur Dioxide } \\
\text { SO2 }\end{array}$ & $\begin{array}{l}\text { Nitrous oride } \\
\text { NOI }\end{array}$ \\
\hline $\begin{array}{c}1 \\
2 \\
3 \\
4 \\
5 \\
6 \\
7 \\
8 \\
9 \\
10 \\
11 \\
12 \\
13 \\
14 \\
15 \\
16 \\
17 \\
18 \\
19 \\
20 \\
21 \\
22 \\
23 \\
24 \\
25 \\
26 \\
27 \\
28 \\
29 \\
30 \\
31 \\
32 \\
33\end{array}$ & 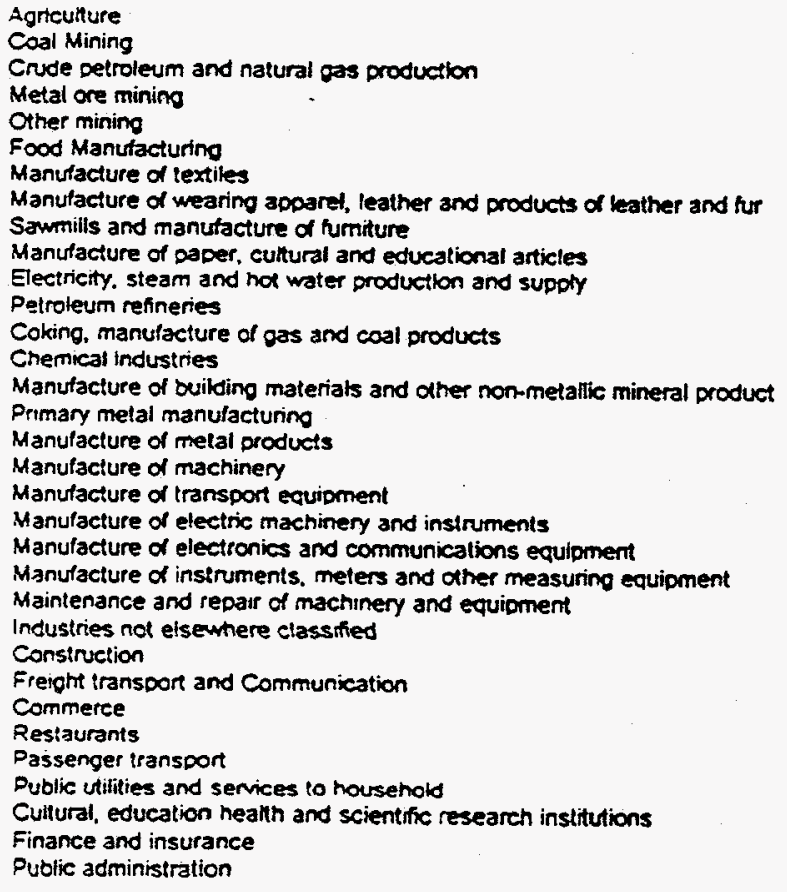 & $\begin{array}{r}772.5 \\
45.1 \\
43.8 \\
15.1 \\
35.3 \\
305.1 \\
274.6 \\
77.0 \\
35.6 \\
109.7 \\
65.1 \\
60.2 \\
10.0 \\
300.0 \\
132.2 \\
179.5 \\
80.0 \\
231.1 \\
66.3 \\
98.5 \\
643 \\
13.0 \\
23.3 \\
17.3 \\
401.6 \\
112.7 \\
170.4 \\
46.8 \\
25.2 \\
94.8 \\
192.6 \\
78.6 \\
52.6\end{array}$ & $\begin{array}{l}0.000 \\
0.071 \\
3.036 \\
0.000 \\
0.000 \\
0.030 \\
0.020 \\
0.000 \\
0.000 \\
0.020 \\
0.284 \\
1.003 \\
0.010 \\
5.297 \\
0.253 \\
0.962 \\
0.030 \\
0.188 \\
0.054 \\
0.080 \\
0.052 \\
0.000 \\
0.000 \\
0.000 \\
1.074 \\
0.192 \\
0.000 \\
0.000 \\
0.009 \\
0.025 \\
0.051 \\
0.021 \\
0.016\end{array}$ & $\begin{array}{l}0.000 \\
0.000 \\
0.000 \\
0.000 \\
0.000 \\
0.000 \\
0.000 \\
0.000 \\
0.000 \\
0.000 \\
0.000 \\
0.000 \\
0.000 \\
0.000 \\
0.000 \\
0.000 \\
0.000 \\
0.000 \\
0.000 \\
0.000 \\
0.000 \\
0.000 \\
0.000 \\
0.000 \\
0.000 \\
0.000 \\
0.000 \\
0.000 \\
0.000 \\
0.000 \\
0.000 \\
0.000 \\
0.000\end{array}$ & $\begin{array}{r}0.000 \\
0.915 \\
48.305 \\
0.000 \\
0.000 \\
0.058 \\
0.043 \\
0.000 \\
0.000 \\
0.107 \\
2.534 \\
9.696 \\
0.590 \\
10.277 \\
1.159 \\
3.120 \\
0.221 \\
0.474 \\
0.474 \\
0.474 \\
0.474 \\
0.000 \\
0.000 \\
0.000 \\
1.556 \\
0.994 \\
0.000 \\
0.000 \\
0.201 \\
0.153 \\
0.153 \\
0.153 \\
0.153\end{array}$ & $\begin{array}{l}0.000 \\
0.000 \\
0.000 \\
0.000 \\
0.000 \\
0.000 \\
0.000 \\
0.000 \\
0.000 \\
0.000 \\
0.000 \\
0.000 \\
0.000 \\
0.000 \\
0.000 \\
0.000 \\
0.000 \\
0.000 \\
0.000 \\
0.000 \\
0.000 \\
0.000 \\
0.000 \\
0.000 \\
0.000 \\
0.000 \\
0.000 \\
0.000 \\
0.000 \\
0.000 \\
0.000 \\
0.000 \\
0.000\end{array}$ & $\begin{array}{l}0.000 \\
0.000 \\
0.000 \\
0.000 \\
0.000 \\
0.000 \\
0.000 \\
0.000 \\
0.000 \\
0.000 \\
0.000 \\
0.000 \\
0.000 \\
0.000 \\
0.000 \\
0.000 \\
0.000 \\
0.000 \\
0.000 \\
0.000 \\
0.000 \\
0.000 \\
0.000 \\
0.000 \\
0.000 \\
0.000 \\
0.000 \\
0.000 \\
0.000 \\
0.000 \\
0.000 \\
0.000 \\
0.000\end{array}$ \\
\hline
\end{tabular}


TABLE 21 Direct Emissions from Use of Petroleum Products, 1990 (million tonnes)

\begin{tabular}{|c|c|c|c|c|c|c|c|}
\hline & Sectors & $\begin{array}{l}\text { Cutout f } \\
\text { (Billion Yuan)! }\end{array}$ & $\begin{array}{l}\text { Products } \\
\text { O Tonnel }\end{array}$ & $\begin{array}{c}\text { Methene } \\
\text { CHA }\end{array}$ & $\begin{array}{c}\text { Crtan Dioxide } \\
\mathrm{CO} 2\end{array}$ & $\begin{array}{l}\text { Sulfur Dioride } \\
\text { sor }\end{array}$ & $\begin{array}{l}\text { Nieras arde } \\
\text { Mor }\end{array}$ \\
\hline $\begin{array}{c}1 \\
2 \\
3 \\
4 \\
5 \\
5 \\
7 \\
8 \\
9 \\
10 \\
11 \\
12 \\
13 \\
14 \\
15 \\
16 \\
17 \\
18 \\
19 \\
20 \\
21 \\
22 \\
23 \\
24 \\
25 \\
26 \\
27 \\
28 \\
29 \\
30 \\
31 \\
32 \\
33\end{array}$ & 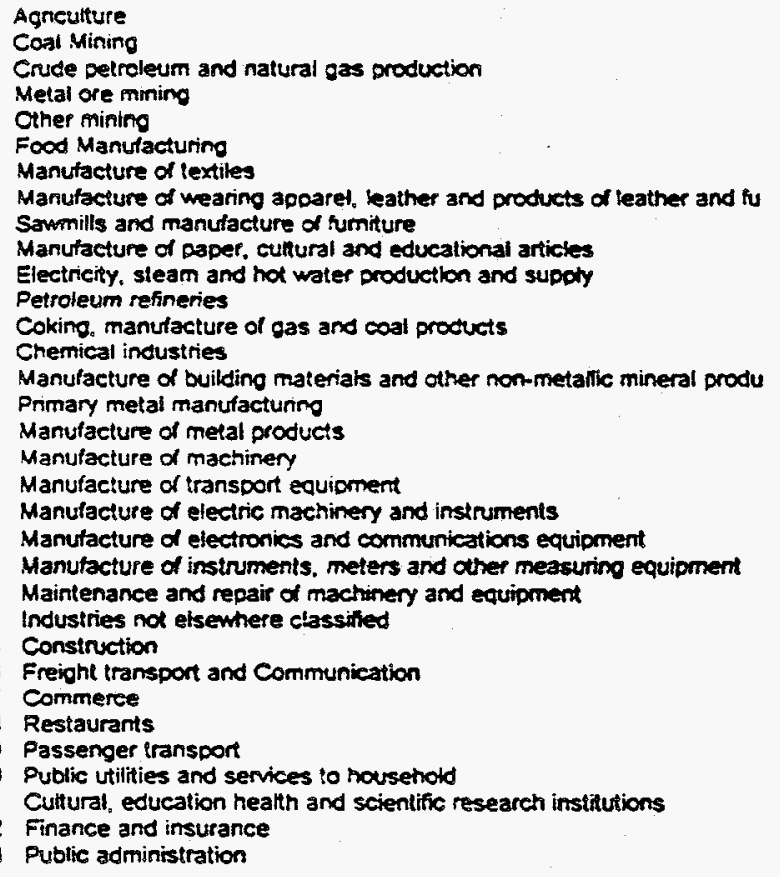 & $\begin{array}{r}772.5 \\
45.1 \\
43.8 \\
15.1 \\
35.3 \\
305.1 \\
274.6 \\
77.0 \\
35.6 \\
109.7 \\
65.1 \\
60.2 \\
10.0 \\
300.0 \\
132.2 \\
179.5 \\
80.0 \\
231.1 \\
66.3 \\
98.5 \\
64.3 \\
13.0 \\
23.3 \\
17.3 \\
401.6 \\
112.7 \\
170.4 \\
46.8 \\
25.2 \\
94.8 \\
192.6 \\
78.6 \\
62.6\end{array}$ & $\begin{array}{r}10.888 \\
748 \\
13.143 \\
0 \\
0 \\
1.040 \\
913 \\
0 \\
0 \\
326 \\
11.281 \\
90.655 \\
378 \\
28.346 \\
4.847 \\
5.200 \\
847 \\
1.518 \\
435 \\
647 \\
422 \\
0 \\
0 \\
0 \\
0 \\
3.409 \\
17.730 \\
595 \\
163 \\
571 \\
1.634 \\
3.321 \\
1.356 \\
1.079\end{array}$ & $\begin{array}{l}0.003 \\
0.00 \\
0.003 \\
0.000 \\
0.000 \\
0.000 \\
0.000 \\
0.000 \\
0.000 \\
0.000 \\
0.003 \\
0.023 \\
0.000 \\
0.007 \\
0.001 \\
0.001 \\
0.000 \\
0.000 \\
0.000 \\
0.000 \\
0.000 \\
0.000 \\
0.000 \\
0.000 \\
0.001 \\
0.004 \\
0.000 \\
0.000 \\
0.000 \\
0.000 \\
0.001 \\
0.000 \\
0.000\end{array}$ & $\begin{array}{l}3.979 \\
0.273 \\
4.803 \\
0.000 \\
0.000 \\
0.380 \\
0.334 \\
0.000 \\
0.000 \\
0.149 \\
4.122 \\
33.128 \\
0.138 \\
9.627 \\
1.771 \\
1.900 \\
0.309 \\
0.555 \\
0.159 \\
0.236 \\
0.154 \\
0.000 \\
0.000 \\
0.000 \\
1.246 \\
6.479 \\
0.248 \\
0.060 \\
0.209 \\
0.597 \\
1.214 \\
0.495 \\
0.394\end{array}$ & $\begin{array}{l}0.000 \\
0.000 \\
0.000 \\
0.000 \\
0.000 \\
0.000 \\
0.000 \\
0.000 \\
0.000 \\
0.000 \\
0.000 \\
0.000 \\
0.000 \\
0.000 \\
0.000 \\
0.000 \\
0.000 \\
0.000 \\
0.000 \\
0.000 \\
0.000 \\
0.000 \\
0.000 \\
0.000 \\
0.000 \\
0.000 \\
0.000 \\
0.000 \\
0.000 \\
0.000 \\
0.000 \\
0.000 \\
0.000\end{array}$ & $\begin{array}{l}0.019 \\
0.001 \\
0.022 \\
0.000 \\
0.000 \\
0.002 \\
0.002 \\
0.000 \\
0.000 \\
0.001 \\
0.019 \\
0.155 \\
0.001 \\
0.045 \\
0.008 \\
0.009 \\
0.001 \\
0.003 \\
0.001 \\
0.001 \\
0.001 \\
0.000 \\
0.000 \\
0.000 \\
0.006 \\
0.030 \\
0.001 \\
0.000 \\
0.001 \\
0.003 \\
0.006 \\
0.002 \\
0.002\end{array}$ \\
\hline & $\begin{array}{l}\text { Total } 33 \text { Sectors } \\
\text { Households } \\
\text { Total }\end{array}$ & & $\begin{array}{r}199,493 \\
1.228 \\
200,721\end{array}$ & $\begin{array}{l}0.050 \\
0.000 \\
0.050\end{array}$ & $\begin{array}{r}72.900 \\
0.449 \\
73.349\end{array}$ & $\begin{array}{l}0.000 \\
0.000 \\
0.000\end{array}$ & $\begin{array}{l}0.340 \\
0.002 \\
0.342\end{array}$ \\
\hline
\end{tabular}

TABLE 22 Direct Emissions Coefficients from Use of Petroleum Products, 1990 (tonnes per million yuan of output)

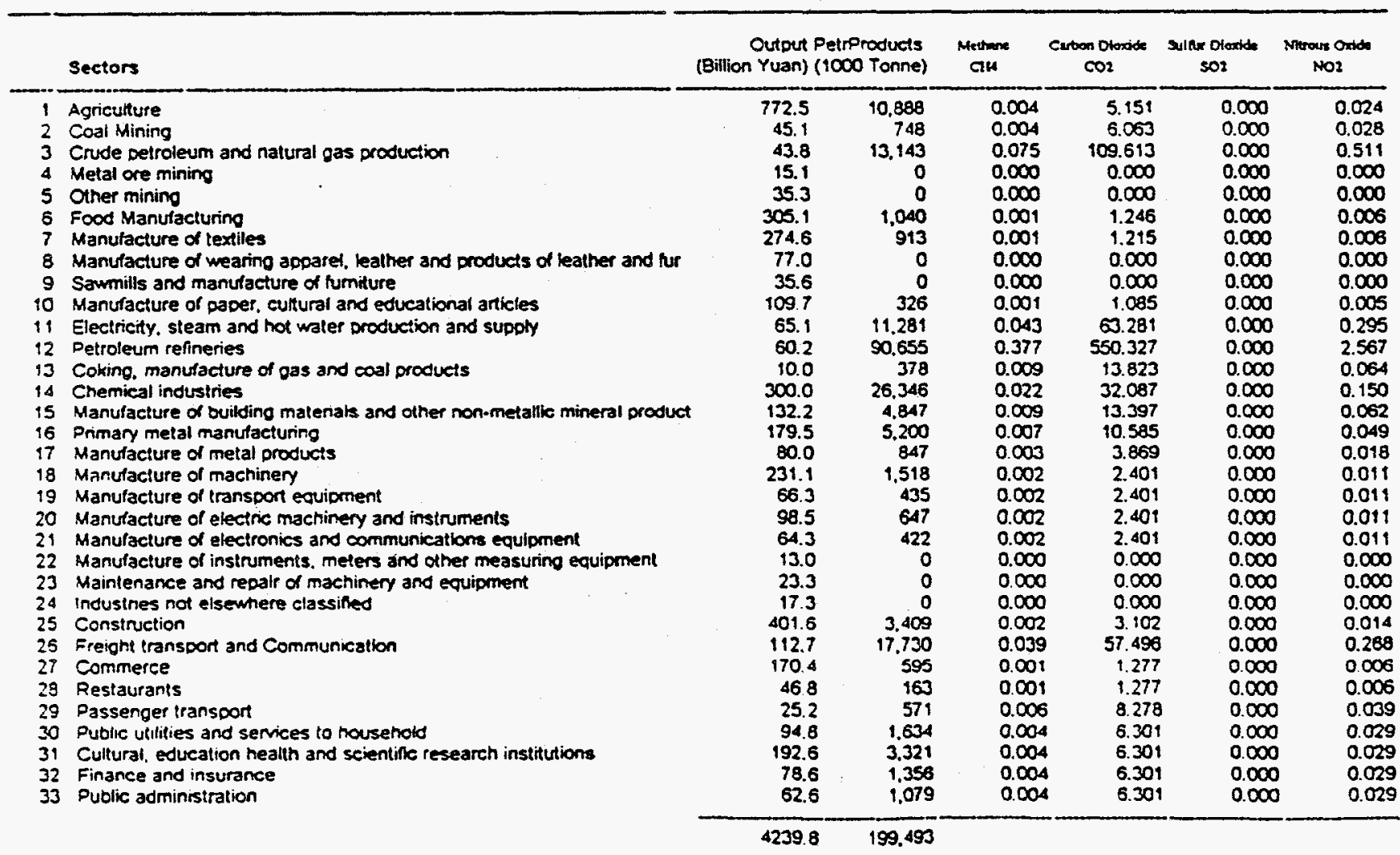


TABLE 23 Direct Emissions from Use of All Fossil Fuels, 1990 (million tonnes)

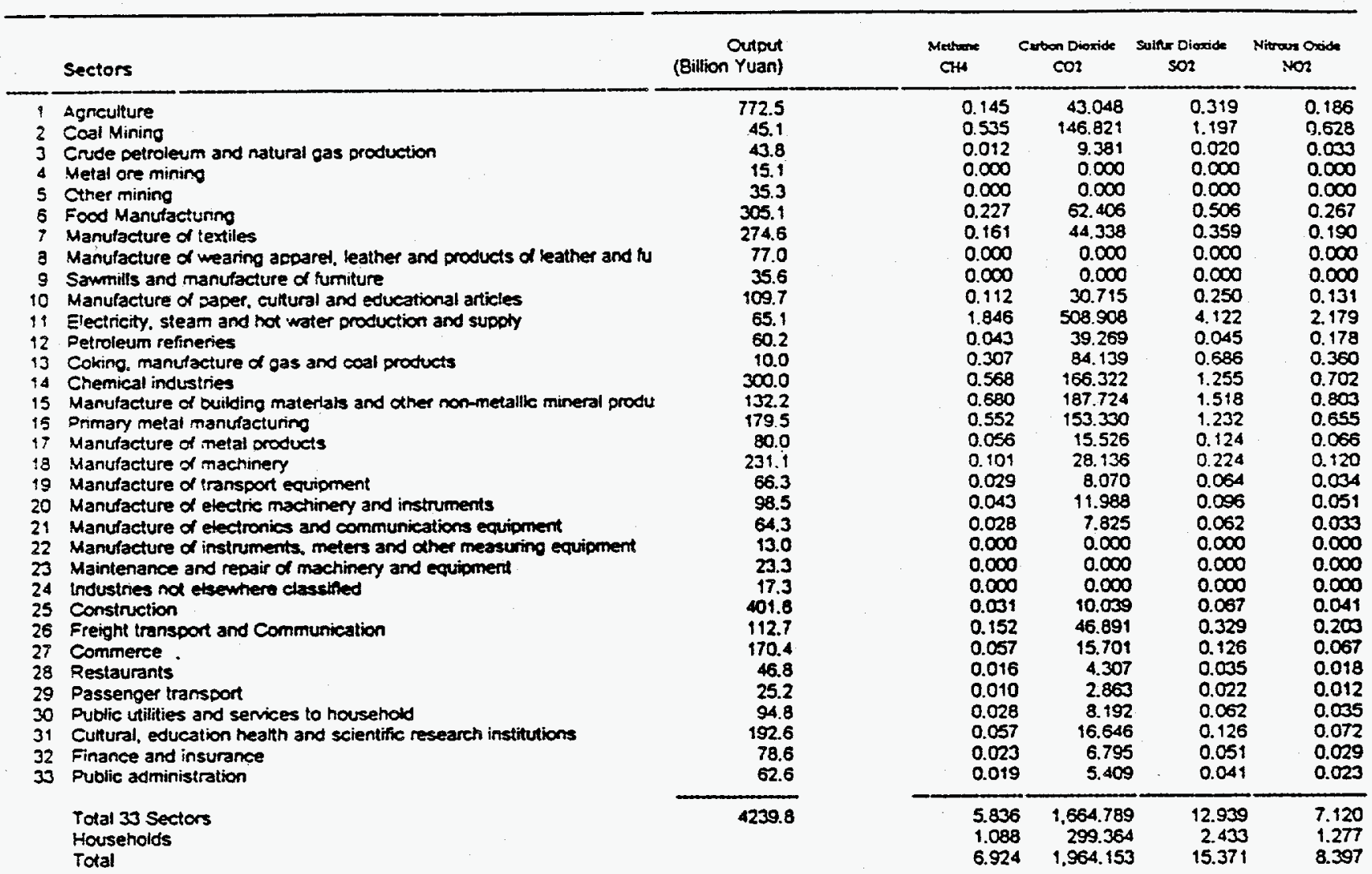

TABLE 24 Direct Emissions Coefficients from Use of All Fossil Fuels, 1990 (tonnes per million yuan of output)

\begin{tabular}{|c|c|c|c|c|c|c|}
\hline & Sectors & $\begin{array}{r}\text { Output } \\
\text { (Billion Yuan) }\end{array}$ & $\begin{array}{c}\text { Metmone } \\
\text { CHH }\end{array}$ & $\begin{array}{c}\text { Curben Dioxide } \\
\mathrm{CO}\end{array}$ & $\begin{array}{l}\text { Sulfix Dioside } \\
\text { SO2 }\end{array}$ & $\begin{array}{l}\text { Nitrous Oxide } \\
\mathrm{NO} 2\end{array}$ \\
\hline $\begin{array}{c}1 \\
2 \\
3 \\
4 \\
5 \\
6 \\
7 \\
8 \\
9 \\
10 \\
11 \\
12 \\
13 \\
14 \\
15 \\
15 \\
17 \\
18 \\
19 \\
20 \\
21 \\
22 \\
23 \\
24 \\
25 \\
26 \\
27 \\
29 \\
29 \\
30 \\
31 \\
32 \\
33\end{array}$ & 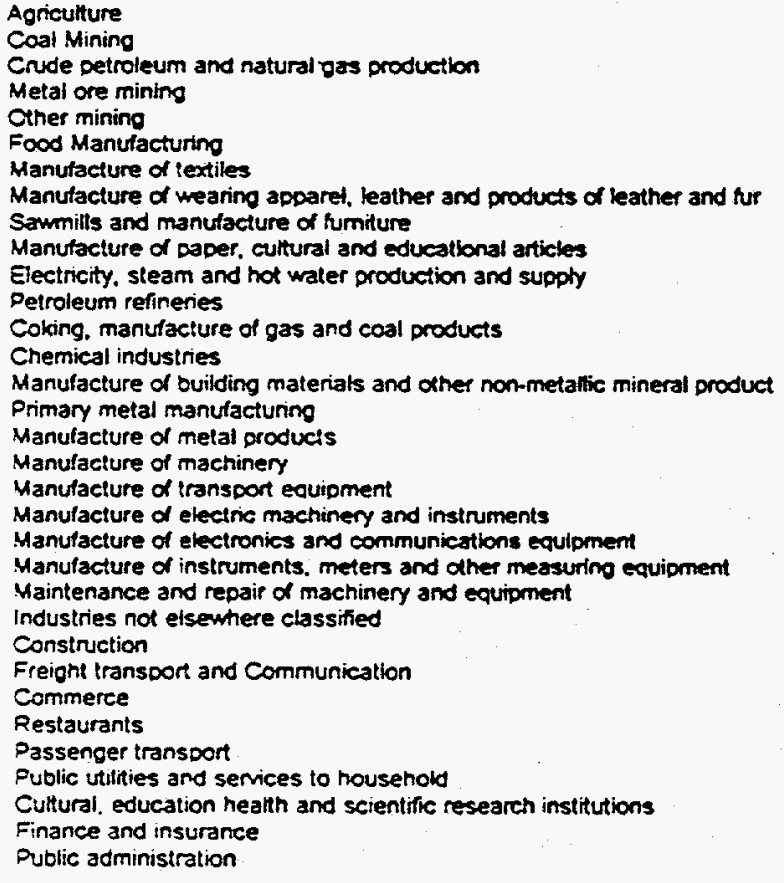 & $\begin{array}{r}772.5 \\
45.1 \\
43.8 \\
15.1 \\
35.3 \\
305.1 \\
274.6 \\
77.0 \\
35.6 \\
109.7 \\
65.1 \\
60.2 \\
10.0 \\
300.0 \\
132.2 \\
179.5 \\
80.0 \\
231.1 \\
66.3 \\
98.5 \\
64.3 \\
13.0 \\
23.3 \\
17.3 \\
401.6 \\
112.7 \\
170.4 \\
46.8 \\
25.2 \\
94.8 \\
192.6 \\
78.6 \\
62.6\end{array}$ & $\begin{array}{r}0.188 \\
11.870 \\
0.280 \\
0.000 \\
0.000 \\
0.743 \\
0.586 \\
0.000 \\
0.000 \\
1.019 \\
28.335 \\
0.715 \\
30.702 \\
1.892 \\
5.142 \\
3.077 \\
0.697 \\
0.436 \\
0.436 \\
0.436 \\
0.436 \\
0.000 \\
0.000 \\
0.000 \\
0.076 \\
1.346 \\
0.333 \\
0.333 \\
0.389 \\
0.296 \\
0.296 \\
0.296 \\
0.296\end{array}$ & $\begin{array}{r}55.727 \\
3.255 .768 \\
214.099 \\
0.000 \\
0.000 \\
204.512 \\
161.468 \\
0.000 \\
0.000 \\
279.942 \\
7.811 .852 \\
652.345 \\
8.417 .796 \\
554.322 \\
1.419 .874 \\
854.208 \\
194.132 \\
121.768 \\
121.768 \\
121.768 \\
121.768 \\
0.000 \\
0.000 \\
0.000 \\
25.000 \\
416.127 \\
92.119 \\
92.119 \\
113.537 \\
86.425 \\
86.425 \\
86.425 \\
86.425\end{array}$ & $\begin{array}{r}0.413 \\
26.536 \\
0.459 \\
0.000 \\
0.000 \\
1.660 \\
1.309 \\
0.000 \\
0.000 \\
2.277 \\
63.269 \\
0.754 \\
68.638 \\
4.182 \\
11.478 \\
6.865 \\
1.552 \\
0.971 \\
0.971 \\
0.971 \\
0.971 \\
0.000 \\
0.000 \\
0.000 \\
0.166 \\
2.921 \\
0.742 \\
0.742 \\
0.858 \\
0.653 \\
0.653 \\
0.653 \\
0.653\end{array}$ & $\begin{array}{r}0.240 \\
13.933 \\
0.752 \\
0.000 \\
0.000 \\
0.876 \\
0.691 \\
0.000 \\
0.000 \\
1.198 \\
33.447 \\
2.962 \\
36.030 \\
2.341 \\
6.077 \\
3.647 \\
0.831 \\
0.520 \\
0.520 \\
0.520 \\
0.520 \\
0.000 \\
0.000 \\
0.000 \\
0.102 \\
1.799 \\
0.395 \\
0.395 \\
0.488 \\
0.372 \\
0.372 \\
0.372 \\
0.372\end{array}$ \\
\hline
\end{tabular}


the combined emission coefficients for all fuels. Table 25 shows the total (direct, indirect, and induced) emission coefficients.

A significant difference is apparent in the emission coefficients between Tables 24 and 25. Many sectors that generate rather low levels of $\mathrm{CO}_{2}$ directly have a demand for inputs whose production generates significant amounts of GHGs. For example, the direct $\mathrm{CO}_{2}$ coefficient for agriculture is about 55.7 tonnes per million yuan of output in this sector (row 1 of Table 24), but the total emission coefficient is 1,215.9 (row 1 of Table 25). Overall, the variance across sectors is substantially lower in Table 25 than they are in Table 24.

The total coefficients will be used in macroeconomic simulations presented in Section 6. Thus, some sectors that would appear to be especially attractive (e.g., agriculture, light manufacturing, and services) lose their comparative advantage when economic interaction effects are taken into account. ${ }^{5}$

\subsection{ENERGY RESERVES}

\subsubsection{Energy Use}

Most of the commercial energy used in China is supplied by fossil fuels. The energy balance for 1990, extracted from EWC/ANL (1994), shows that, from a total of 961.4 Mtce, only $50.7 \mathrm{Mtce}$ came from hydropower. The fossil fuels (coal, natural gas, and oil), show a wide variation in terms of consumption pattern, as well as in potential reserves.

As the dominant fuel in China's economy, coal accounts for more than $75 \%$ of all energy consumption. Coal is used as an energy source for all economic sectors and as a material input for the chemical industries and coking sectors. The distribution of coal consumption is shown in the first two columns of Table 26.

Table 26 shows that the largest single sectoral consumer of coal is electricity services (sector 11), which accounts for $26.8 \%$ of the total. The next single largest consumer is the household sector (15.8\%). Together, Sectors 13, 14, 15, and 16 (coke, chemicals, cement, and steel manufacturing) represent more than $30 \%$ of all coal consumption. Overall, when all of the manufacturing sectors are aggregated, their demand exceeds even electricity services.

5 The total coefficients have been computed by using an open I-O inverse, which includes only direct and indirect (interindustry) interactions. The use of a closed inverse (also including induced, consumer-related interactions) would narrow the disparities between sectors even more. The reason is because of the common nature of consumer-producer good interactions from any amount of consumer spending. The open matrix provides more conservative estimates, and it is difficult to incorporate the closed matrix into this model. However, the difference in emission coefficients and macroeconomic indicators would be very modest. 
TABIE 25 Total Emission Coefficients from Use of All Fossil Fuels, 1990 (tonnes per million yuan of output)

\begin{tabular}{|c|c|c|c|c|c|}
\hline Seclors & $\begin{array}{l}\text { Melhane } \\
\mathrm{CH} 4\end{array}$ & $\begin{array}{c}\text { Cartoon Oloxide } \\
\mathrm{CO} 2\end{array}$ & $\begin{array}{l}\text { Sulfur Dloxide } \\
\text { SO2 }\end{array}$ & $\begin{array}{l}\text { Nilrous Oxide } \\
\text { NO2 }\end{array}$ & $\begin{array}{c}\text { Methane } \\
\mathrm{CH} 4\end{array}$ \\
\hline 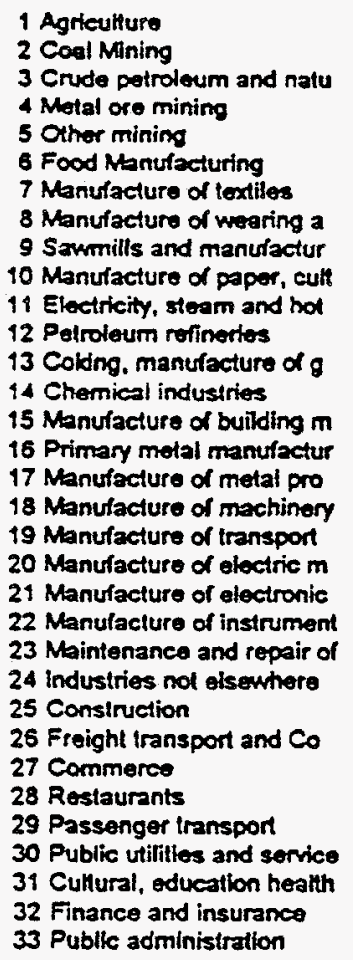 & $\begin{array}{r}4.349 \\
32.199 \\
5.627 \\
0.820 \\
1.352 \\
1.901 \\
4.485 \\
0.886 \\
0.775 \\
3.677 \\
34.110 \\
5.828 \\
31.833 \\
10.211 \\
7.660 \\
9.712 \\
3.169 \\
4.893 \\
1.164 \\
2.760 \\
0.880 \\
0.401 \\
0.118 \\
0.739 \\
0.076 \\
4.957 \\
5.442 \\
0.333 \\
0.728 \\
0.825 \\
1.711 \\
2.900 \\
0.296\end{array}$ & $\begin{array}{r}1,215.906 \\
8,846.306 \\
1,905.682 \\
228.559 \\
375.073 \\
527.910 \\
1.248 .630 \\
246.524 \\
215.991 \\
1,020.585 \\
9,415.714 \\
2.082 .704 \\
8,729.830 \\
2,888.881 \\
2,124.135 \\
2.706 .876 \\
880.664 \\
1,376.761 \\
327.613 \\
769.297 \\
246.222 \\
113.226 \\
32.872 \\
205.281 \\
25.000 \\
1,432.744 \\
1,525.003 \\
92.119 \\
208.185 \\
234.571 \\
484.953 \\
814.784 \\
86.425\end{array}$ & $\begin{array}{r}9.684 \\
71.956 \\
11.999 \\
1.827 \\
3.016 \\
4.240 \\
9.996 \\
1.974 \\
1.726 \\
8.200 \\
76.148 \\
12.135 \\
71.164 \\
22.693 \\
17.085 \\
21.645 \\
7.068 \\
10.883 \\
2.588 \\
6.149 \\
1.958 \\
0.890 \\
0.263 \\
1.647 \\
0.166 \\
10.947 \\
12.112 \\
0.742 \\
1.611 \\
1.830 \\
3.798 \\
6.450 \\
0.653\end{array}$ & $\begin{array}{r}5.202 \\
37.861 \\
8.069 \\
0.977 \\
1.604 \\
2.258 \\
5.341 \\
1.055 \\
0.924 \\
4.367 \\
10.309 \\
9.087 \\
37.364 \\
12.321 \\
9.088 \\
11.567 \\
3.768 \\
5.885 \\
1.401 \\
3.290 \\
1.052 \\
0.484 \\
0.141 \\
0.878 \\
0.102 \\
6.155 \\
6.528 \\
0.395 \\
0.893 \\
1.006 \\
2.078 \\
3.488 \\
0.372\end{array}$ & $\begin{array}{r}0.188 \\
11.870 \\
0.280 \\
0.000 \\
0.000 \\
0.743 \\
0.586 \\
0.000 \\
0.000 \\
1.019 \\
28.335 \\
0.715 \\
30.702 \\
1.892 \\
5.142 \\
3.077 \\
0.697 \\
0.436 \\
0.436 \\
0.436 \\
0.436 \\
0.000 \\
0.000 \\
0.000 \\
0.078 \\
1.346 \\
0.333 \\
0.333 \\
0.389 \\
0.298 \\
0.296 \\
0.296 \\
0.296\end{array}$ \\
\hline
\end{tabular}

The Total Coeficient is the product of the Leontlef imerse and the ditect emission coefficient matrix.

Table 26 also presents data on the consumption of natural gas. Households consume only $12.2 \%$ of the total. Chemical industries (sector 14) are the largest consumer of natural gas, followed by crude petroleum and natural gas products (sector 3). Other significant users of natural gas are construction (sector 25), 7\%; petroleum refineries (sector 12),6.6\%; and primary metal manufacturing (sector 16), 6.3\%. In 1990, the electricity sector consumed only about $1.9 \%$ of the total gas available for the Chinese economy.

Table 26 also contains information on the consumption of petroleum products, such as crude oil, kerosene, and fuel oil (combined). Petroleum refineries use most of the crude oil. The most important consumers of petroleum products are chemical industries (sector 14), $13.1 \%$; freight transportation (sector 26 ), $8.8 \%$; and agriculture (sector 1 ), $5.4 \%$.

The electricity sector consumed about 11 million tons of petroleum products in 1990 (5.6\% of the total). Households consumed 1.2 million tons (about $0.6 \%$ of the total). 
TABLE 26 Energy Consumption in China, 1990

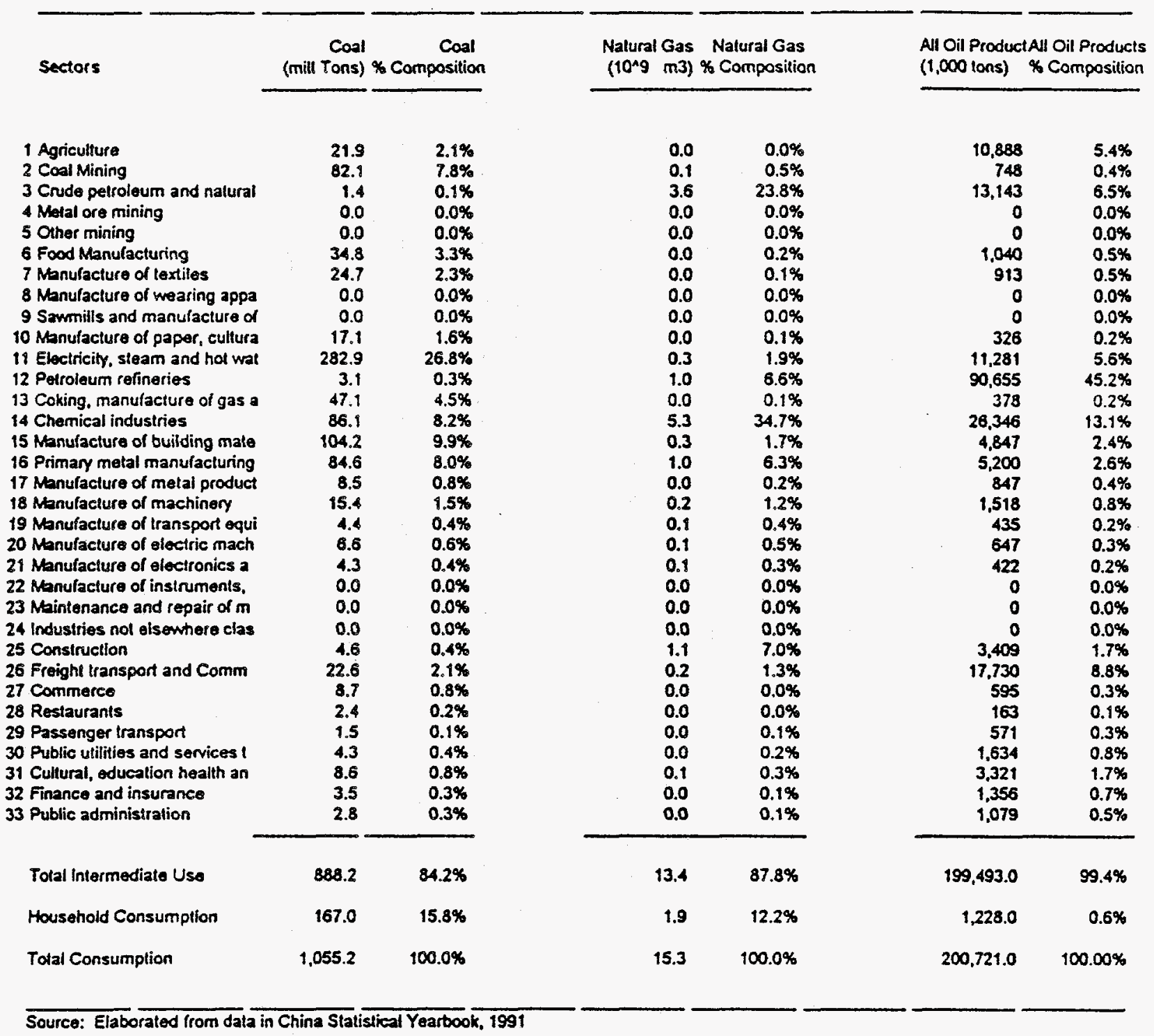

\subsubsection{Current Reserves}

China's coal reserves are impressive on a global scale; they make up more than $11 \%$ of the world's reserves. Among these reserves, bituminous coal accounts for $75 \%$, anthracite for $12 \%$, and lignite for $13 \%$. Geographically, $84 \%$ of China's coal reserves are concentrated in three areas (north, northwest, and northeast).

The total coal reserve differs substantially based on the source. British Petroleum (1993) reports coal reserves of 114,500 million metric tons (tonnes). The official document 
of the Chinese government, Energy in China 1992 (Ministry of Energy [1993]), reported a total of 290,000 million tonnes.

Oil and natural gas reserves are considered to be newly emerging industries in China. The Ministry of Energy (1993) states that more than 373 sedimentary basins could yield oil. However, oil reserves are unevenly distributed, with more than $85 \%$ of the known oil reserves located in the East. Natural gas fields are more evenly distributed; some are near densely populated and developed regions. The same publication reported total (proven, probable, and possible) reserves of 78.7 billion tonnes for oil, and 33 trillion cubic meters (tcm) for natural gas.

The figures for oil and natural gas reserves provided by British Petroleum (1993) also differ (Table 27). Proven oil reserves total 24 billion barrels (approximately 3 billion tonnes), and natural gas totals $1.4 \mathrm{tcm}$. In 1992, China possessed about $2.4 \%$ of the world's total proven reserves of oil and about $1.0 \%$ of the world's proven reserves of natural gas (British Petroleum 1993).

\subsection{FUTURE RESERVE POTENTIAL}

\subsubsection{Natural Gas}

Natural gas exploitation in China has not received significant attention in the past. Exploration for natural gas has been very low, and the proven reserves are believed to be only $3 \%$ of estimated resources ( $43 \mathrm{tcm}$ ) (EWC/ANL 1994). On the other hand, the reserves classified as probable are about $8.4 \mathrm{tcm}$, and the proven reserves are estimated at $1.0 \mathrm{tcm}$ (Ministry of Energy 1994).

Consumption of these reserves is low when compared with other nations. In 1990, China used 15.3 billion cubic meters $(\mathrm{bcm})$, and the ratio of reserves to production is over a 68-year period. Production, though, is increasing rapidly. From 1985 to 1991, natural gas production increased $24.2 \%$.

The electricity sector bears a higher unit price than other sectors because of discriminatory pricing. Calculations of the natural gas price for China's economy for 1990 indicate an average of $0.183 \mathrm{yuan} / \mathrm{m}^{3}$. In the same year, sales to electricity services amounted to $6.43 \%$ of the total value of natural gas, even though this sector only consumed $0.28 \mathrm{bcm}$, or $1.8 \%$ of the total natural gas output. 
Restrictions on the availability of natural gas are included in the DLP simulations presented in Section 6 . To calculate these restrictions, two assumptions are necessary:

- A minimum reserves-to-production (R/P) ratio for normal gas recovery. Not all the proven natural gas reserves can be exploited at once because of physical limits. This report assumes a threshold R/P ratio equal to 2 .

- The amount of proven reserves that will be available in the future. Any producing area passes through several stages - from initial discovery to maturity to depletion. On the basis of experience around the world for areas beginning to be explored, the amount of reserves is likely to be increased or can at least be maintained. Because China is not a mature hydrocarbon area, it is assumed that the current level of reserves can be kept constant by replacing production by reserve additions, even with sizable increases in gas use.

Both assumptions were combined to find the maximum annual extractable reserves of natural gas for China. Table 28 shows the results of these calculations. A maximum of 500,000 million cubic meters $(\mathrm{mcm}$ ) can be used each year, which is valued at 91.634 billion yuan.

All sectors of China's economy are expected to consume more natural gas. To set an upper bound for the use of gas for power generation, this study assumed that sectors other than electricity will increase their gas demand at the same rate of growth as the GDP. The limits for consumption of natural gas by the electricity sector were calculated on the basis of this assumption and on the total gas reserve constraint explained above. The results are presented in Table 29.

\subsubsection{Nuclear Power}

Until recently, nuclear power has not been part of China's energy mix. Although nuclear technical energy resources and capabilities were present, the first nuclear station did not begin generating power until 1991. Construction of the 300-MW Qingshan plant began in 1985, and sharp increases in the cost of the materials used affected its commercial viability. The plant generating costs are much higher than the costs of generating electricity with coal would be in that region ${ }^{6}$ (EWC/ANL 1994).

6 A proposed second stage in the Qinshan plant will consist of two additional 600-MW units; work is expected to start in this decade. Meanwhile, work on another nuclear power station, using mainly Western European equipment and consisting of two 900-MW units, was started in 1987 and was expected to start generating in 1994. The total investment of this project is more than $\$ 4.5$ billion, and the average cost is estimated to be $9 \not / \mathrm{kWh}$. 
TABLE 28 Natural Gas Reserve Calculations for China

\begin{tabular}{lrr}
\hline \multicolumn{1}{c}{ Category } & Proven & Probable \\
\hline Reserves (bcm) & 1,000 & 8,400 \\
Value of reserves (billion yuan) & 183.268 & $1,539.451$ \\
Extractable reserves (billion yuan) & 91.634 & 769.725 \\
\hline
\end{tabular}

TABLE 29 Constraints for Natural Gas Used in the DLP Simulation (billion yuan) $^{a}$

Assumption/Year

Total

Economywide Demand for Natural Gas (DN) Other Than

in the Electricity Sector

Year $2000 \quad \mathrm{DN} 2000=(2.619) \times(1+0.085)^{10}$

Year 2010 DN2010 $=(2.619) \times(1+0.085)^{10} 10 \times(1+0.075)^{10}$

Year 2025 DN2025 $=(2.619) \times(1+0.085)^{10} 10 \times(1+0.075)^{10} \times(1+0.065)^{15}$

12.204

31.388

Electricity Sector Natural Gas Demand (DE) Potential

Year $2000 \quad D E 2000=91.634-D N 2000$

85.712

Year 2010 DE2010 $=91.634-\mathrm{DN} 2010$

Year 2025 DE2025 = 91.634 - DN2025

60.246

a These calculations were made on the basis of 91.634 billion yuan of extractable natural gas reserves.

Some coastal provinces and cities are in the early stages of conducting work for new nuclear power projects (Ministry of Energy 1993). Nuclear power is expected to play an increasingly important role in easing the pressure on the supply of fossil energy, especially in coastal areas where economic growth is very high and where there is a shortage of energy (EWC/ANL 1994). Rapidly industrializing and energy-short eastern China is a prime candidate for nuclear power expansion.

Various projections have been made over the years. By using a conservative approach, EWC/ANL (1994) projects that by the year 2000, the installed nuclear capacity will reach 3-4 GW, and by 2050, nuclear energy may supply as much as $10 \%$ of total energy and $20 \%$ of electric-generating capacity.

The same reports point to the main constraints on the expansion of nuclear power: (1) a shortage of capacity for building large nuclear plants, (2) a shortage of construction capital, and (3) an insufficient number of trained managers. 
Projections of energy use correspond to a scenario of high economic growth and high technological development (EWC/ANL 1992). According to this scenario, nuclear power stations will not only be constructed to meet the energy shortfalls in the coastal areas, but also for other regions of China where large-scale development is expected. Some nuclear energy will also be used for district heating in cities in northern China.

\subsubsection{Hydropower}

Both the electricity sector and the hydroelectric supply have been growing rapidly (Ministry of Energy 1993). Between 1980 and 1990, the average annual growth of generated power was $7.6 \%$. In 1991 , the total installed capacity was $151.47 \mathrm{GW}$. Of that total, 113.59 GW (75\%) came from thermal power plants and $37.88(25 \%)$ from hydroelectric plants. Also in 1991, a total of $677,550 \mathrm{GWh}$ was generated, and hydroelectric power plants supplied $125,090 \mathrm{GWh}(19 \%)$.

Data on the power generation mix for 1990 were collected from Energy in China (Ministry of China 1993) as well as National Response Strategy for Global Climate Change (ADB 1994). Table 30 shows the distribution of electricity generated by each source. In 1990, hydropower accounted for about $20 \%$ of all the electricity sold - a total value of 65,146 million yuan. Assuming that the sales price of electricity is uniform across sources, the total sales of hydropower plants was on the order of 268 million yuan. ${ }^{7}$

The exploitable hydropower resources in China reach $380 \mathrm{GW}$, probably the largest in the world. The distribution of these resources is uneven, with about $68 \%$ of all the exploitable resources lying in southwest China, whereas the principal demand for electricity is in the East. The installed capacity is only $10 \%$ of the exploitable hydropower, so this sector has ample room for growth.

TABLE 30 Fuel Mix in Electricity Generation in China, 1990

\begin{tabular}{lrr}
\hline $\begin{array}{c}\text { Fuel } \\
\text { Source }\end{array}$ & $\begin{array}{c}\text { Sales } \\
\text { (million yuan) }\end{array}$ & $\begin{array}{c}\text { Share }^{\mathrm{a}} \\
(\%)\end{array}$ \\
\hline Coal & $47,084.1$ & 72.27 \\
Crude & 482.4 & 0.74 \\
Petroleum products & $4,260.9$ & 6.54 \\
Natural gas & 268.0 & 0.41 \\
Hydropower and other & $13,050.6$ & 20.03 \\
& & \\
Total & $65,146.0$ & 100.00 \\
\hline
\end{tabular}

a Values may not add because of rounding.

7 Among the existing 22 power stations with a capacity of $1 \mathrm{GW}$ and above, four stations are hydropower plants. The biggest hydropower station was built in 1988 and has a capacity of 2,715 GW. 
However, investment in power plants must be coupled with investment in very long transmission lines. By the year 2000, China plans to transmit $10 \mathrm{GW}$ of new hydropower generated in the Southwest to the East - a distance of $2,000 \mathrm{~km}$. The magnitude of the investments for transmission is relatively large, about 1,000 yuan $/ \mathrm{kW}$. Transmission losses will also be significant - from 7 to $10 \%$ of total generation.

The capacity of reported hydropower facilities under construction exceeds $20 \mathrm{GW}$. Large plants are expected to be centrally funded, whereas numerous medium- and small-size hydropower stations will be constructed by using locally raised funds. By the year 2000, installed capacity of national hydropower will double that of 1991 (Ministry of Energy 1993). This estimate implies that the share of hydroelectricity in the total electricity picture would reduce slightly (from 19 to $18 \%$ ) by year 2000 , when an annual growth rate of $8.5 \%$ for the demand for electricity (equivalent to the upper-bound GDP growth rate) is assumed.

The projections of energy use correspond to a scenario of high economic growth and rapid technological development in the framework of policies (Ministry of Energy 1993). These policies encourage the use of sources other than coal and oil and the increasing electrification of the economy.

\subsubsection{Other Renewables}

Renewable sources of energy are being promoted in China. The current situation and perspectives on wind power, solar power, geothermal use, and biomass installations provide a variety of experiences and expectations. Table 31 presents some highlights of the status and future availability of renewable energy technologies in China.

The vast territory of China is suitable for solar power use in more of two-thirds of land available (Ministry of Energy 1992). Currently, the use of solar water heaters and photovoltaic (PV) cells has increased significantly. China's production capacity of PV cells exceeds $5.5 \mathrm{MW} / \mathrm{yr}$.

Wind resources are more localized; they occur mainly in the western and northwestern parts of the country. More than 120,000 small units have a generating capacity of less than $1 \mathrm{~kW}$ and more than 10,000 units to raise water. Geothermal power is also used in some areas. A number of geothermal plants have a generating capacity of more than $25 \mathrm{MW}$. Biomass resources are also used and promoted in rural areas. It is likely that biomass will continue to be a major source of energy in these areas.

Although progress has been made in the area of other renewable energy sources and their diffusion in China, it is expected that they will contribute up to only $5 \%$ of the total power-generating capacity by 2050 . 
TABLE 31 Data Status for Renewable Fuels and Technologies in China

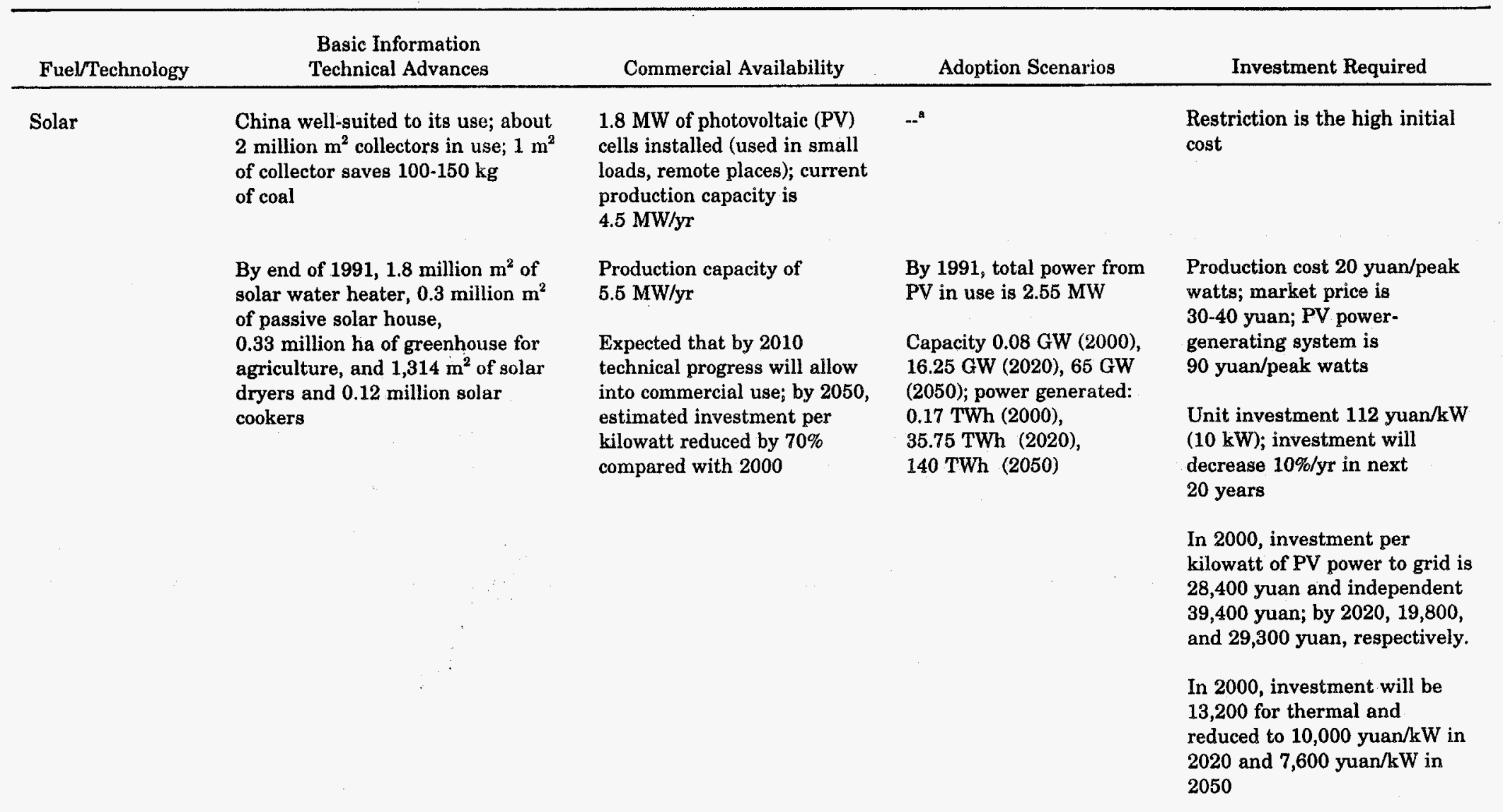




\section{TABLE 31 (Cont.)}

\begin{tabular}{|c|c|c|c|c|}
\hline Fuel/Technology & $\begin{array}{l}\text { Basic Information } \\
\text { Technical Advances }\end{array}$ & Commercial Availability & Adoption Scenarios & Investment Required \\
\hline \multirow[t]{3}{*}{ Wind } & $\begin{array}{l}120,000 \text { small units (less than } \\
1 \mathrm{~kW} \text { ) in operation; total capacity } \\
6.7 \mathrm{MW}\end{array}$ & $\begin{array}{l}\text { Capacity to produce } 20,000 \\
\text { units per year }\end{array}$ & - & $m$ \\
\hline & $\begin{array}{l}11 \text { demonstration farms, total } \\
\text { capacity } \\
10,000 \text { units to raise water }\end{array}$ & $\begin{array}{l}\text { Twelve additional farms in } \\
\text { five years equal } 120 \mathrm{MW} \text {; } \\
\text { total capacity is } 1,000 \mathrm{MW} \text { by } \\
\text { year } 2000\end{array}$ & -- & -- \\
\hline & $\begin{array}{l}\text { Wind power development } \\
\text { optimistic; location complements } \\
\text { coal and hydropower }\end{array}$ & $\begin{array}{l}\text { By } 1991,10,000 \text { units of } \\
60-200 \mathrm{~W}\end{array}$ & $\begin{array}{l}\text { Installed capacity: } \\
0.3 \mathrm{GW}(2000), 0.145 \mathrm{GW} \\
(2020), 0.4 \mathrm{GW}(2050) ; \\
\text { power generated: } \\
0.09 \mathrm{TWh}(2000) \text {, } \\
0.45 \mathrm{TWh}(2020) \text {, } \\
1.28 \mathrm{TWh}(2050) ; \text { coal } \\
\text { equivalent: } 0.037,0.152 \text {, } \\
\text { and } 0.410 \mathrm{Mtce}\end{array}$ & $\begin{array}{l}\text { Grid - medium/large } \\
\text { (yuan/kW): 7,160 }(2000), \\
6,000(2020), 5,500(2050) \\
\text { Independent, mini: } 10,000 \\
(2000), 10,000(2020), 8,000 \\
(2050)\end{array}$ \\
\hline \multirow[t]{2}{*}{ Biomass } & $\begin{array}{l}80 \% \text { of energy used by rural } \\
\text { households provided by traditional } \\
\text { biomass fuels }\end{array}$ & $\begin{array}{l}\text { Biomass will continue to be a } \\
\text { major rural energy source }\end{array}$ & $\begin{array}{l}\text { Potential biogass base } \\
\text { estimated at } 82 \mathrm{Mtce}\end{array}$ & $\begin{array}{l}\text { Cost of building an } 8-\mathrm{m}^{3} \\
\text { biogas pit is } 300 \text { yuan }\end{array}$ \\
\hline & $\begin{array}{l}\text { Biogass program is spread; } \\
\text { estimated } 4.7 \text { million } \mathrm{CH}_{4} \\
\text { generating pits or } 1 \text { billion } \mathrm{m}^{3} \text { of } \\
\mathrm{CH}_{4} \text { per year; contributes less than } \\
1 \% \text { to total biomass energy }\end{array}$ & $\begin{array}{l}5.7 \text { million ha replanted for } \\
\text { firewood }\end{array}$ & $\begin{array}{l}\text { Energy supplied by } \\
\text { biomass is estimated at } \\
220 \text { Mtce in } 2010 \text { and } \\
110 \text { Mtce by } 2050\end{array}$ & $\begin{array}{l}\text { Cost of replacing old stove is } \\
30-50 \text { yran; resulting firewood } \\
\text { savings of } 5-10 \%\end{array}$ \\
\hline
\end{tabular}


TABLE 31 (Cont.)

\begin{tabular}{|c|c|c|c|c|}
\hline Fuel/Technology & $\begin{array}{l}\text { Basic Information } \\
\text { Technical Advances }\end{array}$ & Commercial Availability & Adoption Scenarios & Investment Required \\
\hline \multirow[t]{3}{*}{ Biomass (cont.) } & $\begin{array}{l}\text { Total reserve } 0.23 \text { billion tons coal } \\
\text { equivalent (tce); by } 1992 \text {, capacity } \\
\text { of biogas power stations reached } \\
2.08 \mathrm{MW}\end{array}$ & $\begin{array}{l}\text { Technologies to convert to } \\
\text { high-quality commercial } \\
\text { energy: biomass gasification, } \\
\text { solidification, charcoal con- } \\
\text { version, and biomass oil }\end{array}$ & $\begin{array}{l}\text { The World Bank report } \\
\text { estimates that by } 2050 \\
\text { more than } 20 \% \text { of world } \\
\text { electricity and } 10 \% \text { of } \\
\text { world process will come } \\
\text { from biomass }\end{array}$ & $\begin{array}{l}\text { Biogass power station: } \\
5,000 \text { yuan/kW }(2000,2020, \\
2050)\end{array}$ \\
\hline & & & $\begin{array}{l}\text { Demand for biomass } \\
\text { energy in } 2000,2020 \\
2050 \text { (in billion tce) } 0.236 \text {, } \\
0.216,0.13 \text {, respectively }\end{array}$ & \\
\hline & & & $\begin{array}{l}\text { Proportion of high-quality } \\
\text { utilization of biomass } \\
\text { energy will increase; } \\
\text { predicted that biogas } \\
\text { reaches } 10 \text { million tce and } \\
30 \text { million tce in } 2020 \text { and } \\
2050 \text {, respectively }\end{array}$ & \\
\hline \multirow[t]{2}{*}{ Geothermal } & $\begin{array}{l}\text { More than } 3,000 \text { fields with } \\
\text { geothermal potential (low to } \\
\text { medium temperature); potential to } \\
\text { generate } 1,000 \mathrm{MW} \text { of electricity }\end{array}$ & $\begin{array}{l}\text { Eight power station } \\
\text { demonstrations with } \\
\text { capacities less than } 300 \mathrm{MW} \text {; } \\
\text { in } 1992 \text {, total capacity was } \\
28.6 \mathrm{MW}\end{array}$ & $\begin{array}{l}\text { Direct use of geothermal } \\
\text { power contributed to } \\
0.3-0.5 \text { mtce }\end{array}$ & Investment of 7,000 yuan $/ \mathrm{kW}$ \\
\hline & & $\begin{array}{l}25.5 \mathrm{MW} \text { in plant in Tibet at } \\
0.12 \text { yuan } / \mathrm{kWh}\end{array}$ & $\begin{array}{l}\text { Installation capacity: } \\
0.058 \mathrm{GW}(2000), 0.1 \mathrm{GW} \\
(2020), 0.16 \mathrm{GW}(2050) \\
\text { Power generation: } 0.29 \text {, } \\
0.5 \text {, and } 0.8 \mathrm{TWh} \\
\text { Coal equivalent: } 0.12 \text {, } \\
0.17 \text {, and } 0.26 \mathrm{Mtce}\end{array}$ & $\begin{array}{l}\text { Power station: } 7,000 \text { yuan } / \mathrm{kW} \\
\text { in } 2000,2020,2050\end{array}$ \\
\hline
\end{tabular}

Sources: Ministry of Energy (1993); EWC/ANL (1994); People's Republic of China (1994). 


\subsubsection{Conservation}

Conservation is the result of taking a set of administrative, legislative, economic, and technical measures to reduce energy use in general, or, in the case of energy efficiency, reduce energy use per unit of output. Thus, it can also be thought of as an alternative source of energy supply. Energy conservation is an important goal for the Chinese government. The conservation measures achieved success in the last 10 years (Ministry of Energy 1993). Among other things, the energy consumption per unit of GDP dropped by $30 \%$.

To pursue energy saving, management information systems have been established at different levels of the administration. Besides a number of decrees, regulations and codes of energy savings design have been published. Funding for conservation measures also have increased. In 1991, local governments and various enterprises spent 3.7 billion yuan to save 1.37 Mtce. The state also used more than 1.8 billion yuan from central funds to create an energy saving capacity of 1.15 Mtce.

The industrial sector has made a number of energy conservation achievements in both urban and rural areas. For example, in industrial and transportation activities, the energy coefficient dropped from 304 tce per million yuan in 1990 to 288 tce per million yuan - a reduction of 5.3\%. Achievements in the use of electricity and the use of coal in coalpowered plants are also cited. Electricity savings are about $3 \%$ a year.

Urbanization has quickened with the opening of the Chinese economy. Some conservation measures include the use of coal briquettes, town heating, and improved efficiency of household electric appliances and lights. The rural sector has serious energy shortages. Conservation measures in this sector include the popularization of firewood/coalsaving stoves and the installation of biogas digestors. The agricultural sector has attempted efforts in ecoagriculture and restrained use of fertilizers.

\subsection{UPPER-BOUND CONSTRAINTS ON ENERGY AND TECHNOLOGY}

\subsubsection{Constraints on Energy Use}

Electricity supplied by clean fuels is projected to increase from 1990 to 2025 . These fuels are supplied by hydroelectric, nuclear, and gas-fired power plants. Their share in total electricity generation will be determined by a combination of technical and economic factors. Changes in fuel composition will definitely affect reducing $\mathrm{CO}_{2}$.

Table 32 shows the maximum amount of electricity that can be generated by each of these clean fuels for 2000,2010 , and 2025. The table shows the upper-bound baseline electricity demand (row 1) and allows comparison with the electricity generated by each fuel (rows 2a-2c). In addition, it shows the $\mathrm{CO}_{2}$ reduction requirement for each of the target years and compares it with the maximum reduction attainable with clean fuels in electricity generation. (The reduction requirement is a combination of a $\mathrm{CO}_{2}$ mitigation target and a compliance schedule.) 
TABLE 32 Potential for Clean Fuels in Electricity Generation: Upper-Bound Parameters

\begin{tabular}{|c|c|c|c|c|c|}
\hline No. & Parameter & 1990 & 2000 & 2010 & 2025 \\
\hline 1. & $\begin{array}{l}\text { Upper-bound baseline } \\
\text { electricity demand } \\
\text { (billion } 1990 \text { yuan) }\end{array}$ & 65.146 & 142.000 & 292.000 & 750.000 \\
\hline $2 a$. & $\begin{array}{l}\text { Hydropower potential } \\
\text { (billion } 1990 \text { yuan) }\end{array}$ & 13.051 & 24.446 & 45.825 & 117.556 \\
\hline $2 b$. & $\begin{array}{l}\text { Nuclear power potential } \\
\text { (billion } 1990 \text { yuan) }\end{array}$ & 0.191 & 1.845 & 17.795 & 532.981 \\
\hline $2 c$. & $\begin{array}{l}\text { Gas-fired electricity } \\
\text { potential (billion } 1990 \\
\text { yuan) }\end{array}$ & 0.268 & 71.000 & 124.108 & 94.134 \\
\hline 3. & $\begin{array}{l}\text { Total of } 2 \mathrm{a}-2 \mathrm{c} \text { baseline } \\
\text { demand }(\%)\end{array}$ & 20.740 & 68.510 & 64.290 & 99.290 \\
\hline 4. & $\begin{array}{l}\mathrm{CO}_{2} \text { reduction } \\
\text { requirement }(\%)\end{array}$ & $\mathrm{NA}^{\mathrm{a}}$ & 5.000 & 57.300 & 83.910 \\
\hline 5. & $\begin{array}{l}\text { Maximum } \mathrm{CO}_{2} \text { reduction } \\
\text { attainable with clean } \\
\text { fuels in electricity } \\
\text { generation }(\%)\end{array}$ & NA & 24.200 & 23.840 & 90.100 \\
\hline
\end{tabular}

a NA = not applicable.

The upper-bound electricity demand was calculated by combining the forecast of economic growth with other assumptions in the DLP simulations. In valuation terms, the demand for electricity service will increase continually from 65,146 million yuan (1990) to 750,000 million yuan (2025). Several assumptions were made to calculate the maximum level, or potential, that clean fuels can attain in satisfying this electricity demand.

\subsubsection{Hydroelectric Power}

In 1990, hydropower sales from an installed capacity of $37 \mathrm{GW}$ were 13.051 billion yuan. Currently, hydropower plants use only about $10 \%$ of known hydropower resources, and efforts will continue to increase hydropower capacity. By 2025 , it is assumed that all currently known expansion possibilities will be exhausted, except an allowance for losses of $10 \%$ for inaccessibility, remoteness, and so on. In addition, it is assumed that the installed capacity will grow constantly at a rate of $6.3 \%$ annually for the next 35 years and 
that the corresponding values of 24.446 billion and 45.825 billion yuan will be obtained for the target years 2000 and 2010 . The results are shown in line $2 \mathrm{a}$ of Table 32.

\subsubsection{Nuclear Power}

To obtain the nuclear power potential, a scenario for 2025 is developed in which nuclear power plants satisfy $71.1 \%$ of the demand for electricity. This assumption is based on the current share of nuclear power in France as a maximum level of attainment. China is assumed to receive significant amounts of technical and financial assistance from abroad (e.g., from redistributing carbon tax revenue, selling carbon emission permits, and transferring technology). This assistance will allow for the construction of a strong nuclear industry (Section 6). In 1991, China's installed capacity was less than $300 \mathrm{MW}$; aggressive plans are in place to continue expanding (line $2 \mathrm{~b}$ of Table 32 ). The considered expansion from 1990 to 2025 assumes a constant growth in installed capacity of more than $22 \%$ a year.

\subsubsection{Natural Gas}

Natural-gas-fired power plants consumed only about $1.9 \%$ of available gas in 1990 . As explained earlier, the $\mathrm{R} / \mathrm{P}$ ratio is very high and implies that large amounts of natural gas are available. Projections of extractable gas demand take into account that economic sectors other than electricity services will increase their natural gas consumption at the same rate as GDP growth. This report calculated the upper bound for natural-gas-fired electricity potential as a residual by subtracting the demand of these sectors for extractable gas reserves and valuing the power that could be generated from it. ${ }^{8}$ On the basis of the discussion in Section 5.3, extractable reserves each year are constant through 2025; thus, the upper bound for natural-gas-fired electricity sharply increases in 2000 and then decreases to accommodate the growth of demand in other sectors.

\subsubsection{Technological Trend Parameters}

Technological changes in the energy components of the DLP model simulations come from three sources:

- Changes in electricity intensity,

- Displacement of coal, and

- Autonomous conservation.

8 Except from 1990 to 2000, during which the upper bound is set to be no larger than $50 \%$ of the total demand to take into account time-to-build considerations of natural gas infrastructure. 


\subsubsection{Changes in Electricity Intensity}

The GDP in China will grow at twice the rate of energy consumption (EWC/ANL 1994). However, modernization in industry will lead to more intensive use of electricity. The upper-bound estimate in this report is that electricity consumption will grow at the same rate as the GDP, or electricity use will grow twice as fast as total energy consumption. This trend is typical of countries at the same state of development as China.

\subsubsection{Displacement of Coal}

It is assumed that coal purchases by all sectors, except for fabricated metals (mainly steel production) and electricity services, will be phased out as follows: $10 \%$ from 1990 to $2000,70 \%$ from 2000 to 2010 , and the remaining $20 \%$ from 2010 to 2025 . This phaseout is equivalent to compounded annual average decreases of $0.96,5.40$, and $1.22 \%$ in intermediate coal consumption with respect to the baseline (Table 33). The pace of this adoption of electricity follows the path of the standard logistic, or an "S-shaped" curve.

\subsubsection{Autonomous Conservation}

The term AEEI refers to measures designed to reduce energy inputs per unit of output in production, transportation, and end use. These measures are not explicitly driven by the price mechanism but are available at zero or negative economic cost. Whereas these types of initial improvements could be relatively easy to attain, further progress is likely to

TABLE 33 Technological Change in Energy Use: Upper-Bound Parameters (percentage change)

\begin{tabular}{|c|c|c|c|}
\hline Parameter & $1990-2000$ & $2000-2010$ & $2010-2025$ \\
\hline \multicolumn{4}{|l|}{ Electricity/GDP ratio } \\
\hline Annual average & 0 & 0 & 0 \\
\hline Period total & 0 & 0 & 0 \\
\hline \multicolumn{4}{|c|}{ Displacement of coal ${ }^{a}$} \\
\hline Annual average & 0.96 & 5.40 & 1.22 \\
\hline Period total & 10.00 & 70.00 & 20.00 \\
\hline \multicolumn{4}{|c|}{ Autonomous conservation ${ }^{\mathrm{b}}$} \\
\hline Annual average & 2.50 & 1.50 & 1.00 \\
\hline Period total & 28.01 & 16.05 & 10.46 \\
\hline
\end{tabular}

a Applies to all sectors, except fabricated metals and electricity services.

b Applies to all sectors, except electricity services. 
emerge at a slower pace. On the basis of work by Chandler (1990) and Cline (1992), these considerations are modeled according to the following time path for the annual rate of growth in AEEI: $2.50 \%$ from 1990 to $2000,1.50 \%$ from 2000 to 2010 , and $1.00 \%$ from 2010 to 2025 (equivalent to cumulative period total rates of $28.01,16.05$, and $10.46 \%$, respectively). These reductions affect purchases by all energy users, except for energy inputs in electricity production.

\subsection{LOWER-BOUND CONSTRAINTS IN ENERGY AND TECHNOLOGY}

The implications for the parameter values, ceteris paribus, are assessed under the following assumptions:

- Clean fuels penetrate electricity generation at a slower pace.

- Electricity consumption grows at a rate that is higher than the GDP; coal is displaced by electricity as an intermediate commodity less quickly; and autonomous gains in energy efficiency are modest.

\subsubsection{Constraints on Energy Use}

A set of lower-bound constraints for clean fuels reflects the following possible conditions:

- Domestic or international prices of petroleum and more modest natural gas availability so that fuel prices and unitized capital prices for power generation still favor coal as a prominent fuel for base and intermediate load generation;

- Financial constraints that perpetuate the use of coal to generate intermediate electricity, even in the presence of hydroelectric projects with smaller net present cost (because of the large capital investment that hydropower plants require at the beginning of the project's life); and

- Constrained use of nuclear power because of health/safety and national security considerations.

The parameters in the previous section are based on optimistic assumptions regarding energy reserves and technology. As a counterpoint, another set of parameters 
based on somewhat pessimistic assumptions is used in conjunction with the lower-bound economic parameters in a second set of DLP simulations. ${ }^{9}$

\subsubsection{Hydropower}

It is assumed that only $63 \%$ of the total hydropower potential is used at the end of the period from 2010 to $2025 .^{10}$ This assumption means that approximately $10.97 \%$ of the upper baseline electricity demand in 2025 would be hydro-based, a figure not far from France's 1990 total generation with the same technology (13.60\%) (EUROSTAT 1991).

\subsubsection{Nuclear Power}

The upper-bound case assumed that by 2025, China would reach France's current percentage of nuclear power generation $(71.1 \%$, the highest in the world). The lower-bound case assumed that by 2025 China will be able to generate a maximum of $30 \%$ nuclear, a share similar to the current figure for some European countries (e.g., in 1990, Germany's share was $31.13 \%$ ).

\subsubsection{Gas-Fired Electricity}

Without more complete information, the lower-bound gas-fired electricity potential is assumed to be $25 \%$ (period by period) of the upper-bound potential. The effects of interfuel competition are assumed to be spread in a similar way across generation techniques (except for nuclear, which is modeled as a regulated commodity). The ramifications of these conditions for key parameters are presented in Table 34.

9 Pessimistic energy parameter assumptions applied to pessimistic economic parameter assumptions obtain contradictory results. The reason is that lower-bound economic forecasts yield the following electricity sector outputs: year 2000 - 112 billion yuan; year $2010-166$ billion yuan; and year $2025-258$ billion yuan. Use of these figures would mean that all the coal-fired electricity generation could be met by clean fuel alternatives by 2025 , a more optimistic condition than for the upper-bound combination of economic and energy parameters. Therefore, for the lower-bound energy coefficient adjustments representing interfuel substitution, the lower-bound energy availability parameters were applied to an upper-bound baseline electricity projection (that is why row 1 of Table 34 reads "Upper Baseline Electricity Demand"). This yields coefficient changes that reflect truly pessimistic projections of clean fuel utilization. In the lower-bound simulations in Section 6 , both lower-bound economic and energy parameters were used, except for this one modification.

10 This amount is equivalent to $70 \%$ of potential net of transmission and distribution losses. 
TABLE 34 Potential for Clean Fuels in Electricity Generation: Lower-Bound Parameters

\begin{tabular}{|c|c|c|c|c|c|}
\hline No. & Parameter & 1990 & 2000 & 2010 & 2025 \\
\hline 1. & $\begin{array}{l}\text { Upper baseline electricity } \\
\text { demand (billion } 1990 \\
\text { yuan) }\end{array}$ & 65.146 & 142.000 & 292.000 & 750.000 \\
\hline $2 a$. & $\begin{array}{l}\text { Hydropower potential } \\
\text { (billion } 1990 \text { yuan) }\end{array}$ & 13.051 & 22.067 & 37.341 & 82.289 \\
\hline $2 b$. & $\begin{array}{l}\text { Nuclear power potential } \\
\text { (billion } 1990 \text { yuan) }\end{array}$ & 0.191 & 1.440 & 10.863 & 225.000 \\
\hline $2 c$. & $\begin{array}{l}\text { Gas-fired electricity } \\
\text { potential (billion } 1990 \\
\text { yuan) }\end{array}$ & 0.268 & 66.963 & 62.075 & 47.067 \\
\hline 3. & $\begin{array}{l}\text { Total of } 2 \mathrm{a}-2 \mathrm{c} \text { baseline } \\
\text { demand }(\%)\end{array}$ & 20.740 & 63.710 & 33.770 & 47.320 \\
\hline 4. & $\begin{array}{l}\mathrm{CO}_{2} \text { reduction } \\
\text { requirement (\%) }\end{array}$ & $\mathrm{NA}^{\mathrm{a}}$ & 5.000 & 40.500 & 65.310 \\
\hline 5. & $\begin{array}{l}\text { Maximum } \mathrm{CO}_{2} \text { reduction } \\
\text { attainable with clean } \\
\text { fuels in electricity } \\
\text { generation }(\%)\end{array}$ & $\mathrm{NA}$ & 20.130 & 5.480 & 28.340 \\
\hline
\end{tabular}

a $\mathrm{NA}=$ not applicable.

\subsubsection{Technological Trend Parameters}

A set of lower-bound technological change parameters was also calculated and reflects rates of growth in electricity consumption corresponding to an extremely accelerated modernization of production. Included are two distinct, but simultaneous, movements:

- One movement totally phases out the dual structure of production derived from enduring chronic brownouts (in certain regions, electricity is available one-third of the time every day of the year), while keeping current production techniques.

- The other movement replaces some current technologies with electricityintensive ones (for example, steel production from metal scrap).

This enhanced penetration of electricity is still not assumed to displace all of the use of coal in steam boilers and direct heating processes. Finally, it is possible that substantial gains in autonomous energy efficiency had been attained during the past decade, and the rhythm 
of non-price conservation decreases in an environment dominated by new technologies and market-allocated prices. The ramifications are presented in Table 35.

\subsubsection{Change in Electricity Intensity}

In China, the electricity/GDP ratio tends to rise as income increases, with an average growth rate of $7.3 \%$ per capita from 1950 to 1980 . But as China's economy matured while using old technologies, that figure decreased to a rate of $3.6 \%$ per capita from 1974 to 1980 (Huang 1994). In the upper-bound case, it is assumed that the ratio reached steady state (0\% growth) in 1990 and maintained this value over the entire time horizon. Given the extraordinary ambitions to increase the electrification of the economy, an electricity elasticity of 1.20 is now assumed (similar to that of Singapore and Thailand [between 1990 and 2000]) for the three simulation periods, which implies a rate of growth of the electricity/GDP ratio equal to only $20 \%$ of the increase in the GDP.

\subsubsection{Displacement of Coal}

A logistic adoption path, as in the upper-bound case, is again assumed, although now it calls for less than complete saturation of electricity by 2025 . By 2025 , only $70 \%$ of the total intermediate consumption is phased out as follows: $10 \%$ from 1990 to $2000,40 \%$ from 2000 to 2010 , and $20 \%$ from 2010 to 2025 .

TABLE 35 Technological Change in Energy Use: Lower-Bound Parameters (percentage change)

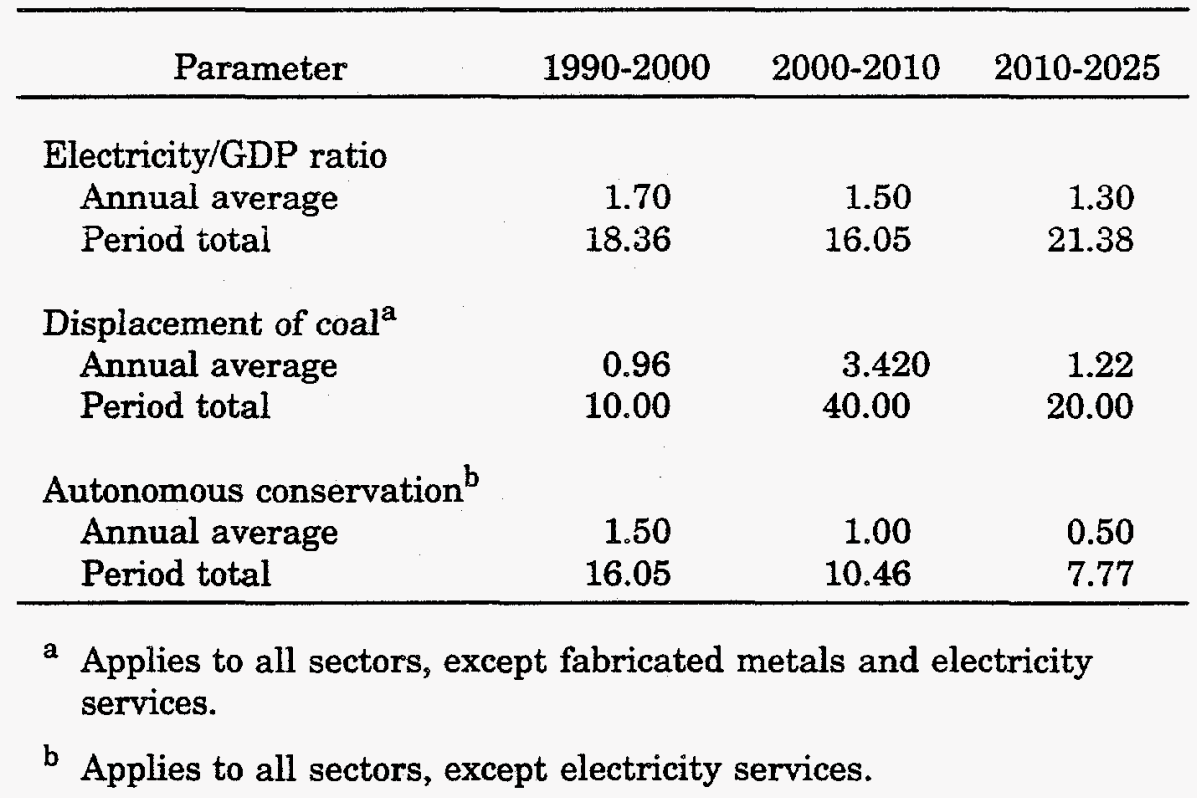




\subsubsection{Autonomous Conservation}

On the basis of major discussions of the range of AEEI (Manne and Richels 1992), the figures of the upper-bound case were reduced downward, assuming that AEEI is $1.5 \%$ from 1990 to $2000,1.0 \%$ from 2000 to 2010 , and $0.5 \%$ from 2010 to 2025 . The corresponding figures for the lower-bound case are presented in Table 35. 


\section{SIMULATION RESULTS}

\subsection{INTRODUCTION}

This section presents the results of the economic-environmental policy simulations for target years 2000,2010 , and 2025. These results are compared with the baseline projections presented in Section 4. Generally, environmental policy in China can significantly affect economic growth. Moreover, major factors that influence this outcome have been identified. The results should be useful to analysts interested in projections of the future of China's economy, as well as those in a position to minimize potential negative impacts.

Five sets of policy simulations were run; each represented a different abatement strategy and variant of the model presented in this report (Table 36):

- Strategy 1: Change in Sectoral Mix,

- Strategy 2: Mandated Conservation,

- Strategy 3: Interfuel Substitution with Current Technology,

- Strategy 4: Interfuel Substitution with Technological Advances, and

- Strategy 5: Combination of Strategies.

The last strategy represents an approximation of the optimal combination of the first four strategies to minimize economic cost (in this study defined in terms of the penalty on economic growth).

Two sets of simulations were conducted on the basis of upper- and lower-bound assumptions. The economic parameters formulated in Section 4 and the technical parameters formulated in Section 5 (for energy reserves and energy technologies) were used. Major economic parameters for each of the various simulations are summarized in Table 37. The technical parameters are repeated in the simulations presented in the following sections.

The $\mathrm{CO}_{2}$ emission reduction target used in this analysis is a stabilization of emissions at $20 \%$ of the year 2000 baseline. Because of the projected growth in China's economy, a progressively higher overall mitigation level will cap emissions at $80 \%$ of their year 2000 levels over the policy horizon. Moreover, most nations have not agreed to immediate attainment of reduction targets, but to phasing them in according to a compliance schedule (International Energy Agency 1992). Accordingly, 25, 60, and 100\% are phased in for 2000,2010 , and 2025, respectively. Table 38 summarizes these considerations; the compliance schedule was chosen in conjunction with the sponsor's and ANL's staff. The mitigation time path is compared with baseline $\mathrm{CO}_{2}$ emission projections in Figure 2.

All of these analyses, except for strategies 1 and 5, have run two simulations: (1) with a compliance $\mathrm{CO}_{2}$ emission reduction target level constraint and (2) without an 
TABLE 36 Carbon Emission Reduction Strategy Simulations

\begin{tabular}{|c|c|c|}
\hline Strategy & Simulation Method & Special Considerations \\
\hline Change in sectoral mix & DLP with $\mathrm{CO}_{2}$ constraint & $\begin{array}{l}\text { Favors sectors with low emissions } \\
\text { (less energy-intensive sectors) }\end{array}$ \\
\hline $\begin{array}{l}\text { Mandated conservation } \\
\text { (across the board) }\end{array}$ & $\begin{array}{l}\text { DLP with reduced energy and emission } \\
\text { coefficients, as well as } \mathrm{CO}_{2} \text { emission constraint }\end{array}$ & $\begin{array}{l}\text { Targets energy-intensive sectors } \\
\text { (now less intensive) }\end{array}$ \\
\hline Interfuel substitution & $\begin{array}{l}\text { DLP with multiple activities per sector, } \\
\mathrm{CO}_{2} \text { constraints, and fuel constraints }\end{array}$ & Favors natural gas, nuclear, and hydro \\
\hline $\begin{array}{l}\text { Technological change } \\
\text { (nonfossil fuel technologies) }\end{array}$ & $\begin{array}{l}\text { DLP with reduced coal use and reduced } \\
\text { energy coefficients in general per sector, }{ }^{b} \text { and } \\
\mathrm{CO}_{2} \text { constraints }\end{array}$ & Favors nonfossil alternatives \\
\hline Combination of 1,3 , and 4 & $\begin{array}{l}\text { DLP with multiple activities per sector, } \mathrm{CO}_{2} \\
\text { constraints, fuel constraints, and higher fuel } \\
\text { costs }\end{array}$ & $\begin{array}{l}\text { Favors natural gas, nuclear, and hydro; } \\
\text { also targets less energy-intensive } \\
\text { sectors }\end{array}$ \\
\hline
\end{tabular}

a Each of the activities in the electricity services sector represents the production of output with a single fuel - coal, oil, natural gas, hydro, or nuclear.

b The strategy represents a combination of coal displacement and AEEI in all sectors, as well as improved fuel combustion efficiency in the electricity services sector. 
TABLE 37 China's DLP Simulation Model

Economic Parameters

\begin{tabular}{|c|c|c|}
\hline $\begin{array}{l}\text { Parameter/ } \\
\text { Time Period }\end{array}$ & $\begin{array}{c}\text { Lower } \\
\text { Bound } \\
(\%)\end{array}$ & $\begin{array}{c}\text { Upper } \\
\text { Bound } \\
(\%)\end{array}$ \\
\hline \multicolumn{3}{|l|}{ GNP growth ${ }^{a}$} \\
\hline $1990-2000$ & 6 & 8.50 \\
\hline $2000-2010$ & 4 & 7.50 \\
\hline $2010-2025$ & 3 & 6.50 \\
\hline \multicolumn{3}{|l|}{ Population growth } \\
\hline $1990-2000$ & $\mathrm{~b}$ & 1.50 \\
\hline $2000-2010$ & $\mathrm{~b}$ & 1.20 \\
\hline $2010-2025$ & $\mathrm{~b}$ & 0.90 \\
\hline \multicolumn{3}{|l|}{ Wage bill } \\
\hline $1990-2000$ & 8.23 & 13.22 \\
\hline $2000-2010$ & 5.60 & 12.60 \\
\hline $2010-2025$ & 4.20 & 11.20 \\
\hline \multicolumn{3}{|l|}{ Capital bill } \\
\hline $1990-2000$ & 9.73 & 14.72 \\
\hline $2000-2010$ & 6.80 & 13.80 \\
\hline $2010-2025$ & 5.10 & 12.10 \\
\hline \multicolumn{3}{|l|}{ Gross output } \\
\hline $1990-2000$ & 5.62 & 8.11 \\
\hline $2000-2010$ & 4.00 & 7.50 \\
\hline 2010-2025 & 3.00 & 6.50 \\
\hline \multicolumn{3}{|l|}{ Discount rate } \\
\hline All periods & 4 & 8 \\
\hline \multicolumn{3}{|l|}{ Depreciation rate } \\
\hline All periods & 5 & 6.70 \\
\hline \multicolumn{3}{|l|}{ Exchange rate } \\
\hline All periods & 4.73 & 4.73 \\
\hline \multicolumn{3}{|l|}{ Trade balance } \\
\hline All periods & 0 & 0 \\
\hline $\begin{array}{l}\text { Capital constraint, } \\
1990\end{array}$ & b & $(2.8579) 10^{12}$ yuan \\
\hline $\begin{array}{l}\text { Labor constraint, } \\
1990\end{array}$ & b & $(1.0324) 10^{12}$ yuan \\
\hline
\end{tabular}

\footnotetext{
a Annual rate, endogenous.

b Same as upper bound.
} 
TABLE $38 \mathrm{CO}_{2}$ Reduction Requirements and Compliance Schedule

\begin{tabular}{|c|c|c|c|c|c|c|}
\hline $\begin{array}{c}\text { Parameter/ } \\
\text { Year }\end{array}$ & $\begin{array}{c}\text { (1) } \\
\text { Baseline } \\
\text { Emissions } \\
\text { (million tonne) }\end{array}$ & $\begin{array}{c}(2)=0.8(1) \\
\text { Target } \\
\text { Emissions } \\
\text { (million tonne) }\end{array}$ & $\begin{array}{c}\text { (3) } \\
\text { Goal } \\
\text { Compliance } \\
(\%)\end{array}$ & $\begin{array}{c}(4)=(3) \times 697 \\
\text { Goal } \\
\text { Compliance } \\
\text { (million tonne) }\end{array}$ & $\begin{array}{c}\text { (5) }=3,485-(4) \\
\text { Achieved } \\
\text { Emissions } \\
\text { (million tonne) }\end{array}$ & $\begin{array}{c}(6)=[(1-5)+1] \\
\text { Achieved } \\
\text { Reduction } \\
(\%)\end{array}$ \\
\hline \multicolumn{7}{|l|}{ Upper Bound $^{\mathrm{a}}$} \\
\hline 2000 & 3,485 & 2,788 & 25.00 & 174 & 3,311 & 5.00 \\
\hline 2010 & 7,183 & 2,788 & 60.00 & 418 & 3,067 & 57.30 \\
\hline \multirow[t]{2}{*}{2025} & 18,473 & 2,788 & 100.00 & 697 & 2,788 & 84.91 \\
\hline & (1) & $(2)=0.8(1)$ & (3) & $(4)=(3) \times 552$ & $(5)=2760-(4)$ & $(6)=[(1-5)+(1)]$ \\
\hline \multicolumn{7}{|l|}{ Lower Bound ${ }^{b}$} \\
\hline 2000 & 2,760 & 2,208 & 25.00 & 138 & 2,622 & 5.00 \\
\hline 2010 & 4,085 & 2,208 & 60.00 & 331 & 2,429 & 40.50 \\
\hline 2025 & 6,365 & 2,208 & 100.00 & 552 & 2,208 & 65.31 \\
\hline
\end{tabular}

a For the upper-bound case, the goal is to reach an emissions cap (target) of 2,788 million tonne of $\mathrm{CO}_{2}$, which represents a $20 \%$ reduction of year 2000 baseline emissions. In the year 2000 , this goal requires the reduction of 697 million tonne. However, the attainment of this target is phased in at compliance levels of 25,60 , and 100\% in 2000, 2010, and 2025, respectively.

b For the lower-bound case, the goal is to reach an emission cap (target) of 2,208 million tonne of $\mathrm{CO}_{2}$. This target is also phased in at compliance levels of 25,60 , and $100 \%$. 


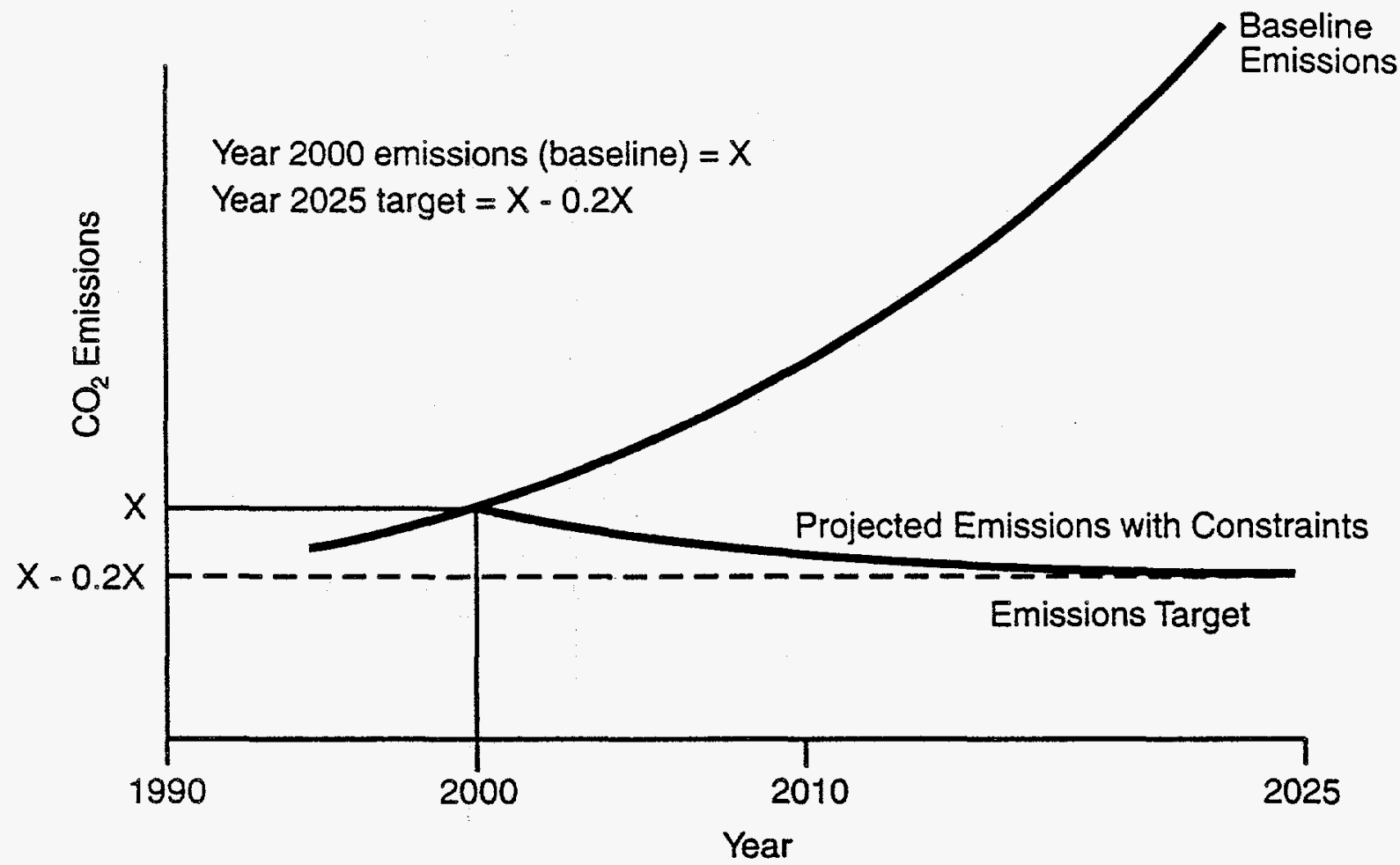

FIGURE 2 Projected $\mathrm{CO}_{2}$ Emissions for China (upper-bound case)

explicit constraint, thereby identifying the maximum attainable emission reduction with that strategy. For Strategy 1, the two cases are (1) with a $\mathrm{CO}_{2}$ emission reduction constraint plus sectoral constraints on final demand that limit major rearrangements of the economy (Section 4), and (2) with a $\mathrm{CO}_{2}$ emission reduction constraint, but a relaxation of the final demand constraints. Finally, only one simulation is manageable and relevant to Strategy 5.

\subsection{SIMULATIONS FOR THE YEAR 2000: UPPER-BOUND CASE}

\subsubsection{Strategy 1: Change in Sectoral Mix}

This simulation examines what changes in relative proportions of sectoral gross output can meet the $\mathrm{CO}_{2}$ emission reduction policy target at the lowest macroeconomic cost to China's economy. The rationale for this strategy is that some sectors have lower $\mathrm{CO}_{2}$ emissions per unit of output than others. Moreover, given the general equilibrium nature of this model, elements of both direct and indirect emissions per unit of GNP are incorporated (Section 5). Heavy industry is characterized by much larger direct emissions coefficients than are the service sectors. For example, compare the direct coefficient for electricity services (7.8119 ton/thousand yuan [tty]) and coking (84,178 tty) with that of the service sector 
$(0.0864 \mathrm{tty})$ and agriculture $(0.0557 \mathrm{tty}) .{ }^{11}$ However, with respect to total coefficients, the relative superiority of the cultural/educational/social service sector over the electricity services decreases from a factor of 100 to a factor of 50; the relative superiority of the agricultural sector over electricity services decreases from a factor of 125 to a factor of 12 .

The results of simulating Strategy 1 are presented in Table 39. Total $\mathrm{CO}_{2}$ emissions are reduced to 3,311 million tons in the year 2000 , thus reducing emissions by $5 \%$, without loosening any of the sectoral constraints to avoid dramatic changes in final demand, as is necessary for other target years. Moreover, $\mathrm{SO}_{\mathrm{x}}$ emissions are reduced by even more (5.09\%). This reduction comes at a relatively small cost of lowering the GDP (total final demand) growth from 8.50 to $8.46 \%$. Overall, the GDP is less than $1 \%$ lower in the year 2000 than the baseline estimate ( 4,686 billion yuan vs. 4,704 billion yuan), while the gross output of the simulation is equal to the baseline level.

Gross output in most sectors declines. The most significant declines are found in coal mining, paper, electricity, petroleum refining, and cultural/educational/social services. Gross output in agriculture, food manufacturing, and freight transportation increases.

Strategy 1 is not likely to be a prime strategy to meet all of the required reductions in later target years because it calls for a significant rearrangement of the economy. However, it can provide useful insights in two related ways. The first insight is as a general guide to a greener economy. Relative price changes lead to a shift toward less energyintensive goods. The second insight is that the secular time path associated with economic development calls for increased industrialization first and then increased service orientation. Coupled with this fact is China's fast-rising real wage rate and subsequent increase in consumer spending.

A "w/o constraint" (without constraint) simulation was not run because the 5\% compliance target was so readily obtained by keeping more reasonable upper and lower bounds on final demand ( 80 and $120 \%$ of baseline, respectively).

\subsubsection{Strategy 2: Mandated Conservation}

One of the primary strategies for pollution mitigation is conservation. Conservation is often characterized as an improvement in energy efficiency or productivity and can be interpreted in one of two ways: (1) technology and energy prices are fixed, but energy use can be reduced by eliminating wasteful practices, or (2) energy use can be reduced by implementing energy-saving technological advances. These practices are often referred to as AEEIs to distinguish them from alterations in energy use in response to changes in relative prices. Other conservation measures are those mandated, or regulated, by the government.

11 Some sectors do not use significant amounts of coal, and therefore have no direct coefficients. Because these sectors use inputs directly and indirectly from other sectors in the economy, all total $\mathrm{CO}_{2}$ coefficients are positive (columns 2 and 4 of Table 37 ). 
TABLE 39 Simulation Results: China DLP Model 1-U (1990-2000)

\begin{tabular}{|c|c|c|c|c|c|c|c|c|c|c|c|c|c|c|}
\hline \multirow[b]{3}{*}{ Agriculture } & \multirow{3}{*}{$\begin{array}{c}\begin{array}{c}\text { Baseline } \\
2000\end{array} \\
\begin{array}{c}\text { Final } \\
\text { Demand }\end{array} \\
1.367\end{array}$} & \multirow{3}{*}{$\frac{\begin{array}{c}\text { Gross } \\
\text { Output }\end{array}}{2,171}$} & \multirow{3}{*}{$\frac{\begin{array}{c}\mathrm{CO} 2 \\
\text { (mil ton) }\end{array}}{121}$} & \multirow[b]{2}{*}{$\begin{array}{c}\mathrm{SO2} \\
\text { (mil ton) }\end{array}$} & \multirow{2}{*}{$\begin{array}{c}\text { DLP } \\
1990 \\
\begin{array}{c}\text { Final } \\
\text { Demand }\end{array}\end{array}$} & \multirow[b]{2}{*}{$\begin{array}{l}\text { Gross } \\
\text { Output }\end{array}$} & \multirow[b]{2}{*}{$\begin{array}{c}\mathrm{CO} \\
\text { (mil ton) }\end{array}$} & \multirow[b]{2}{*}{$\begin{array}{c}\mathrm{SO}_{2} \\
\text { (mil ton) }\end{array}$} & \multicolumn{4}{|l|}{$\begin{array}{l}\text { DLP } \\
2000 \\
\end{array}$} & \multirow{2}{*}{$\begin{array}{l}\mathrm{CO2} \\
\text { COEFFICIENT } \\
\text { (iontho Yuan) }\end{array}$} & \multirow{2}{*}{$\begin{array}{c}\mathrm{SO2} \\
\text { COEFFICIENT } \\
\text { (tontho Yuan) }\end{array}$} \\
\hline & & & & & & & & & $\begin{array}{c}\text { Final } \\
\text { Domand }\end{array}$ & $\begin{array}{l}\text { Gross } \\
\text { Output }\end{array}$ & $\begin{array}{c}\mathrm{CO} 2 \\
\text { (mil ton) }\end{array}$ & $\begin{array}{c}\mathrm{SO2}_{\text {(mil ton) }}\end{array}$ & & \\
\hline & & & & 1 & 491 & 879 & 49 & $\mathbf{0}$ & 1,387 & 2,249 & 125 & 1 & 0.0557 & 0.0004 \\
\hline 2 Coal mining & 31 & 108 & 352 & 3 & 11 & 47 & 153 & 1 & 18 & 89 & 290 & 2 & 3.2568 & 0.0265 \\
\hline 3 Crudo petroleum \& natural gas prod & 25 & 109 & 23 & 0 & 9 & 46 & 10 & $\mathbf{0}$ & 25 & 105 & 23 & 0 & 0.2141 & 0.0005 \\
\hline 4 Metal oro mining & 0 & 28 & 0 & 0 & $\mathbf{0}$ & 14 & 0 & o & 0 & 27 & 0 & 0 & 0.0000 & 0.0000 \\
\hline 5 Other mining & $\mathbf{0}$ & 67 & $\mathbf{0}$ & 0 & $\mathbf{0}$ & 31 & 0 & $\mathbf{0}$ & 0 & 68 & $\mathbf{0}$ & $\mathbf{0}$ & 0.0000 & 0.0000 \\
\hline 8 Food manulacturing & 346 & 561 & 115 & 1 & 245 & 353 & 72 & 1 & 482 & 719 & 147 & $\mathbf{I}$ & 0.2045 & 0.0017 \\
\hline 7 Manufacture of textiles & 168 & 502 & 81 & 1 & 79 & 237 & 38 & 0 & 168 & 498 & 80 & 1 & 0.1815 & 0.0013 \\
\hline 8 Manufacture of apparel & 98 & 135 & 0 & 0 & 46 & 63 & 0 & 0 & 98 & 134 & 0 & 0 & 0.0000 & 0.0000 \\
\hline 9 Sawmills and manufacture of turniture & 12 & 65 & 0 & 0 & 8 & 34 & 0 & 0 & 12 & 64 & 0 & 0 & 0.0000 & 0.0000 \\
\hline 10 Manulacture of paper and educ material & 42 & 233 & 65 & 1 & 30 & 116 & 32 & 0 & 42 & 228 & 64 & 1 & 0.2799 & 0.0023 \\
\hline 11 Eloctricity, steam and hot water prod & 19 & 142 & 1.105 & 9 & 7 & 64 & 499 & 4 & 10 & 128 & 1.000 & 8 & 7.8119 & 0.0633 \\
\hline 12 Petroloum refineries & 7 & 141 & 92 & 0 & 2 & 61 & 40 & $\mathbf{0}$ & 3 & 135 & 88 & 0 & 0.6523 & 0.0008 \\
\hline 13 Coking. manufacture of gas \& coal & 5 & 18 & 154 & 1 & 2 & 9 & $\pi$ & 1 & 5 & 18 & 150 & 1 & 8.4178 & 0.0686 \\
\hline 14 Chemical industries & 36 & 616 & 342 & 3. & 25 & 287 & 159 & 1 & 36 & 606 & 336 & 3 & 0.5543 & 0.0042 \\
\hline 15 Manufacture of building materials & 6 & 250 & 355 & 3 & 2 & 117 & 166 & 1 & $\mathbf{3}$ & 245 & 347 & 3 & 8.4199 & 0.0115 \\
\hline 16 Primary motal manufacturing & $\mathbf{0}$ & 311 & 266 & 2 & 0 & 161 & 137 & 1 & 0 & 302 & 258 & 2 & 0.8542 & 0.0069 \\
\hline 17 Manulacture of motal products & 32 & 148 & 29 & 0 & 23 & 78 & 15 & 0 & 32 & 145 & 28 & $\mathbf{0}$ & 0.1941 & 0.0016 \\
\hline 18 Manufacture of machinery & 174 & 331 & 40 . & 0 & 123 & 203 & 25 & 0 & 174 & 325 & 40 & 0 & 0.1218 & 0.0010 \\
\hline 19 Manufacture of transport oquipment & 46 & 92 & 11 & 0 & 32 & 54 & 7 & 0 & 48 & 89 & 11 & 0 & 0.1218 & 0.0010 \\
\hline 20 Manulacture of electric machinery & 69 & 159 & 19 & 0 & 48 & 94 & 11 & $\mathbf{0}$ & 69 & 154 & 19 & 0 & 0.1218 & 0.0010 \\
\hline 21 Manufacture of electronlcs oquip & 78 & 125 & 15 & 0 & 37 & 59 & 7 & $\mathbf{0}$ & 52 & 89 & 11 & 0 & 0.1218 & 0.0010 \\
\hline 22 Manufacture of instruments & 0 & 14 & 0 & 0 & 0 & 7 & 0 & 0 & 0 & 13 & 0 & $\mathbf{0}$ & 0.0000 & 0.0000 \\
\hline 23 Maintenance and repair of machinery & 72 & 77 & 0 & 0 & 26 & 27 & 0 & 0 & 36 & 41 & 0 & 0 & 0.0000 & 0.0000 \\
\hline 24 Industries not elsewhere classifiad & 29 & 69 & 0 & 0 & 21 & 40 & 0 & 0 & 29 & 69 & 0 & 0 & 0.0000 & 0.0000 \\
\hline 25 Construction & 681 & 681 & 17 & 0 & 321 & 321 & $\mathbf{8}$ & 0 & 681 & 681 & 17 & 0 & 0.0250 & 0.0002 \\
\hline 26 Freight Iransport and communication & 138 & 292 & 122 & 1 & 49 & 122 & 51 & 0 & 138 & 296 & 123 & 1 & 0.4161 & 0.0029 \\
\hline 27 Commerce & 86 & 347 & 32 & 0 & 34 & 155 & 14 & 0 & 96 & 346 & 32 & o & 0.0921 & 0.0007 \\
\hline 28 Restaurants & 79 & 79 & 7 & 0 & 44 & 44 & 4 & $\mathbf{0}$ & 79 & 79 & 7 & 0 & 0.0921 & 0.0007 \\
\hline 29 Passenger transport & 46 & 78 & 9 & 0 & 16 & 29 & 3 & 0 & 48 & 77 & $\boldsymbol{9}$ & 0 & 0.1135 & 0.0009 \\
\hline 30 Public utilities and services to house & 244 & 305 & 26 & 0 & 86 & 110 & 10 & 0 & 244 & 302 & 26 & 0 & 0.0864 & 0.0007 \\
\hline 31 Cultural, oducation and health services & 518 & 620 & 54 & 0 & 183 & 226 & 20 & $\mathbf{0}$ & 457 & 558 & 48 & $\mathbf{0}$ & 0.0864 & 0.0007 \\
\hline 32 Finance and insurance & 6 & 161 & 14 & 0 & 2 & 75 & 6 & 0 & 6 & 160 & 14 & 0 & 0.0864 & 0.0007 \\
\hline 33 Public administration & 212 & 212 & 18 & 0 & 75 & 75 & 6 & 0 & 212.25 & 212 & 18 & 0 & 0.0864 & 0.0007 \\
\hline Total & 4,704 & 9,247 & 3,485 & 27 & 2,080 & 4,240 & 1,620 & 13 & 4,686 & 9,247 & 3.311 & 26 & & \\
\hline
\end{tabular}

Final Demand and Gross Output in billions of 1990 Yuans

Final Demand(GDP) Growth Rate
$1990-2000 \quad 8.46 \%$ CO2 Emission Reduction

1990-2000 
These measures are not in response to relative price changes. However, they differ from AEEI, which is at least always economically viable. Mandated levels of conservation cannot always be achieved on this basis and may involve uneconomic options.

Before performing this analysis, some important implications of the pure conservation strategy should be noted. Any reduction in energy use lowers total production costs in most sectors. What are the implications of this cost reduction? One possibility is price decreases. However, in most economies, prices are "sticky" downward. Moreover, this model would have difficulty simulating such price decreases and the responses to them. Other possibilities are available, including energy cost decreases being offset by the costs of operating and depreciating energy-saving equipment. This possibility is simulated by increasing the machinery coefficient in each sector by an amount equal to the sum of the cost savings of the various fuels. ${ }^{12,13}$

The results of this simulation of Strategy 2 with a $5 \% \mathrm{CO}_{2}$ emission reduction constraint are presented in Table 40. The overall decline in the GDP is only $0.01 \%$ (from 8.5 to $8.49 \%$ ), and the gross output is essentially the same as the baseline. The gross outputs of the metal ore mining, coking, and primary metal sectors increase because these support the machinery industry. However, significant decreases in the gross outputs of energy extraction, petroleum refining, and electricity are projected.

In addition to the phased-in compliance schedule (Table 38), this study simulated the full $20 \%$ mitigation level for Strategy 2 for the year 2000 . Such a reduction level is considered achievable by costless conservation measures (Chandler 1990; Cline 1992). ${ }^{13}$ In addition, across-the-board $20 \%$ reductions are assumed in both primary and secondary energy use in each sector.

Not every sector can meet a $20 \%$ autonomous conservation target, but any sectoral deviations from this economywide attainable level would not significantly affect the results. The optimal level of conservation would also call for differentiation across sectors. Recalling the discussion of $\mathrm{CO}_{2}$ emission coefficients, the prime sectoral targets for conservation would be those with larger coefficients. Therefore, the estimates of negative impacts on GDP should be considered as upper bounds.

The results of simulations w/o constraint are presented in Table 41. First, $\mathrm{CO}_{2}$ emissions are projected to be 2,587 million tons, or a $25.78 \%$ decrease from baseline. The

12 New machinery is not purchased on a current account in an I-O table, but as the capital accumulation element final demand. This aspect is modeled to create no significant bias. In fact, it may be superior to the inclusion of these costs in the depreciation row because placing it in intermediate sectors also incorporates the indirect effects of simulating the production of this machinery.

13 Simulations were also run in which the cost savings were transferred to labor. The results for these two offset cases were essentially the same, and only the machinery offset case is presented. 
TABLE 40 Simulation Results: China DLP Model 2-U (1990-2000), with Constraint

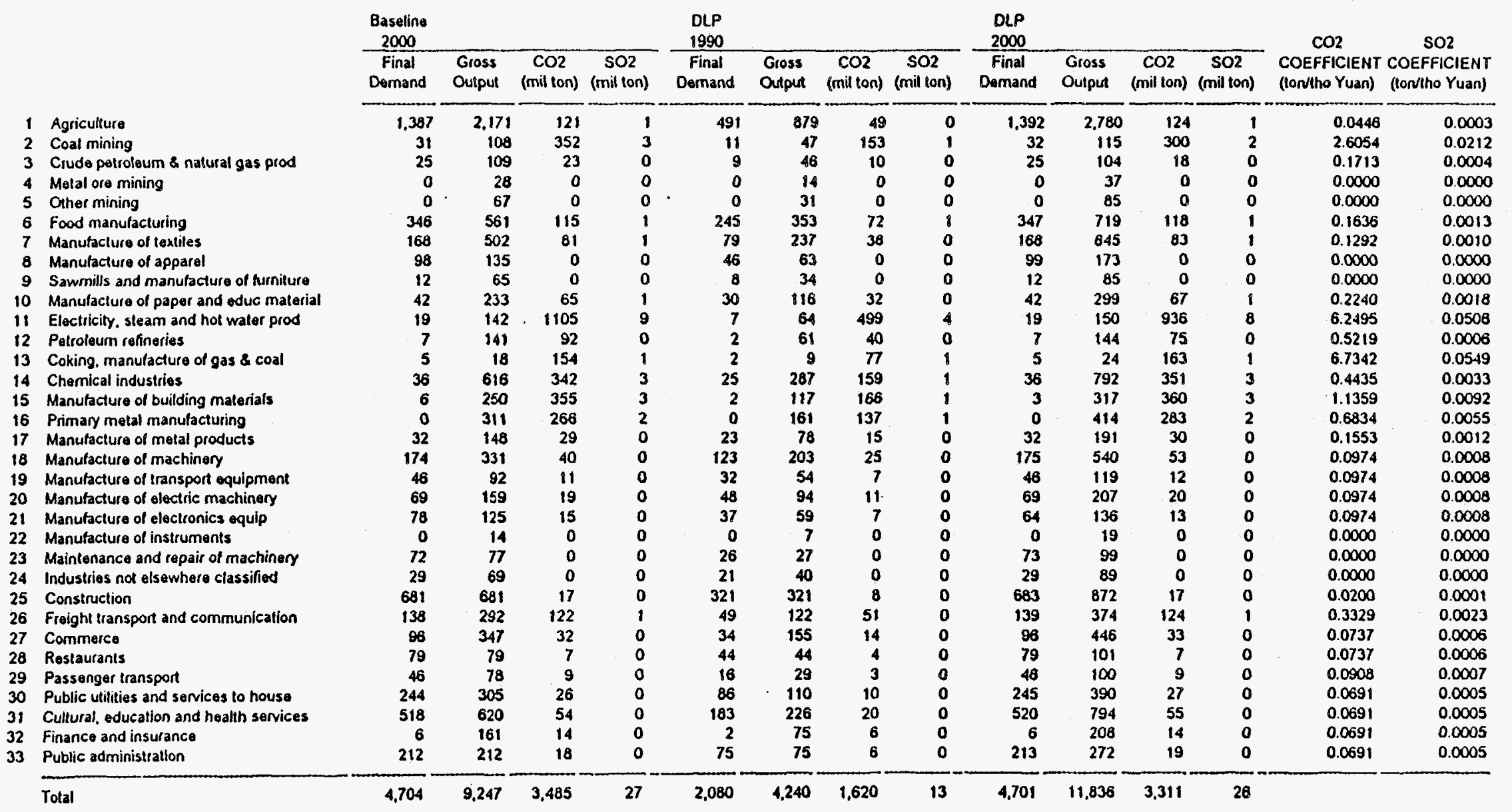

Final Damand and Gross Output in billions of 1990 Yuans

$\begin{array}{cccc}\text { Final Domand(GDP) Growh Rate } & \text { CO2 Emisston Roduction } \\ 1990-2000 & 0.49 \% & 1990-2000 & 5.00 \%\end{array}$ 
TABLE 41 Simulation Results: China DLP Model 2-U (1990-2000), without Constraint

\begin{tabular}{|c|c|c|c|c|c|c|c|c|c|c|c|c|c|c|c|c|c|c|c|c|c|c|c|c|c|c|c|c|c|}
\hline & & & & \multicolumn{8}{|c|}{$\begin{array}{r}\text { DLP } \\
-1990 \\
\end{array}$} & \multirow{2}{*}{\multicolumn{2}{|c|}{$\begin{array}{c}\mathrm{CO2} \\
\text { COEFFICIENT O } \\
\text { (ton/tho Yuan) }\end{array}$}} & & & & & & & & & & & & & & & \\
\hline & & & & & & & & & & & & & & & & $\begin{array}{c}\text { Final } \\
\text { Demand }\end{array}$ & $\begin{array}{l}\text { Gross } \\
\text { Output }\end{array}$ & $\begin{array}{l}\mathrm{CO} 2 \\
\text { mil ton) }\end{array}$ & $\begin{array}{l}\mathrm{SO} 2 \\
\text { (mil ton) }\end{array}$ & $\begin{array}{l}\text { Final } \\
\text { Demand }\end{array}$ & $\begin{array}{l}\text { Gross } \\
\text { Output }\end{array}$ & $\begin{array}{l}\mathrm{CO} 2 \\
\text { mill tor }\end{array}$ & $\begin{array}{l}\mathrm{SO2} \\
\text { iil ton) }\end{array}$ & $\begin{array}{l}\text { Final } \\
\text { Demand }\end{array}$ & $\begin{array}{l}\text { Gross } \\
\text { Oulput }\end{array}$ & $\begin{array}{c}\mathrm{CO} 2 \\
\text { (mil ton) }\end{array}$ & $\begin{array}{l}\mathrm{SO2} \\
\text { (mil (on) }\end{array}$ & & \\
\hline 1 Agriculture & & & & & & & 49 & & & & & & & & giculture & 1.387 & 2,171 & 121 & 1 & 491 & 879 & & 0 & 1,387 & 2.172 & 97 & 1 & 0.0446 & 0.0003 \\
\hline 2 Coal mining & & & & & & & 153 & & & & & & & & oal mining & 31 & 108 & 352 & 3 & 11 & 47 & & 1 & 31 & 90 & 234 & 2 & 2.6054 & 0.0212 \\
\hline 3 Crude petroleum \& natural gas prod & & & & & & & 10 & & & & & & & & rude petroleum \& natural gas prod & 25 & 109 & 23 & 0 & $\boldsymbol{9}$ & 46 & & 0 & 25 & 01 & 14 & 0 & 0.1713 & 0.0004 \\
\hline Melal ore mining & & & & & & & 0 & & & & & & & & letal ore mining & 0 & 28 & 0 & 0 & 0 & 14 & & 0 & 0 & 29 & 0 & 0 & 0.0000 & 0.0000 \\
\hline Other mining & & & & & & & $\mathbf{0}$ & & & & & & & & ther mining & 0 & 67 & 0 & 0 & 0 & 31 & & 0 & 0 & 67 & a & $\mathbf{0}$ & 0.0000 & 0.0000 \\
\hline Food manufacturing & & & & & & & 72 & & & & & & & & ood manufacturing & 346 & 561 & 115 & 1 & 245 & 353 & & $i$ & 346 & 561 & 92 & 1 & 0.1638 & 0.0013 \\
\hline Manufacture of textiles & & & & & & & 38 & & & & & & & & lanufacture of textiles & 168 & 502 & 81 & 1 & 79 & 237 & & 0 & 168 & 504 & 65 & 1 & 0.1292 & 0.0010 \\
\hline Manufacture of apparel & & & & & & & 0 & & & & & & & & lanutacture of apparel & 98 & 135 & 0 & 0 & 46 & 63 & & 0 & 98 & 135 & $\mathbf{0}$ & 0 & 0.0000 & 0.0000 \\
\hline Sawmills and manufacture of furniture & & & & & & & 0 & & & & & & & & awmills and manufacture of furniture & 12 & 65 & 0 & 0 & 8 & 34 & & 0 & 12 & 66 & 0 & 0 & 0.0000 & 0.0000 \\
\hline Manulacture of paper and educ malerial & & & & & & & 32 & & & & & & & & lanulacture of paper and educ material & 42 & 233 & 65 & 1 & 30 & 116 & & $\mathbf{0}$ & 42 & 234 & 52 & $\mathbf{0}$ & 0.2240 & 0.0018 \\
\hline & & & & & & & 499 & & & & & & & & lectricity, steam and hol water prod & 19 & 142 & 105 & 9 & 7 & 64 & 45 & 4 & 19 & 117 & 731 & 6 & 6.2495 & 0.0506 \\
\hline & & & & & & & 40 & & & & & & & & otroleum refineries & 7 & 141 & 92 & 0 & 2 & 61 & & 0 & 7 & 113 & 59 & $\mathbf{0}$ & 0.5219 & 0.0006 \\
\hline & & & & & & & 77 & & & & & & & & oking, manufacture of gas \& coal & $\mathbf{s}$ & 18 & 154 & 1 & 2 & 9 & & $\mathrm{i}$ & 5 & 19 & 127 & 1 & 6.7342 & 0.0549 \\
\hline & & & & & & & 159 & & & & & & & & hemical industries & 36 & 616 & 342 & 3 & 25 & 287 & & 1 & 36 & 619 & 275 & 2 & 0.4435 & 0.0033 \\
\hline & & & & & & & 166 & & & & & & & & lanufacture of building materials & 6 & 250 & 355 & 3 & 2 & 117 & 16 & i & 3 & 247 & 281 & 2 & 1.1359 & 0.0092 \\
\hline & & & & & & & 137 & & & & & & & & rimary motal manufacturing & 0 & 311 & 266 & 2 & 0 & 161 & & 1 & 0 & 323 & 221 & 2 & 0.6834 & 0.0055 \\
\hline & & & & & & & 15 & & & & & & & & anufacture of motal products & 32 & 148 & 29 & 0 & 23 & 78 & & 0 & 32 & 149 & 23 & 0 & 0.1553 & 0.0012 \\
\hline & & & & & & & 25 & & & & & & & & anufacture of machinery & 174 & 331 & 40 & 0 & 123 & 203 & & 0 & 174 & 422 & 41 & 0 & 0.0974 & 0.0008 \\
\hline & & & & & & & 7 & & & & & & & & anutacture of transpert equipment & 46 & 92 & 11 & 0 & 32 & 54 & & 0 & 46 & 93 & 9 & 0 & 0.0974 & 0.0000 \\
\hline & & & & & & & 11 & & & & & & & & anufacture of electric machinery & 69 & 159 & 19 & 0 & 48 & 94 & & 0 & 69 & 162 & 16 & $\mathbf{0}$ & 0.0974 & 0.0008 \\
\hline & & & & & & & 7 & & & & & & & & anufacture of electronics oquip & 78 & 125 & 15 & 0 & 37 & 59 & & 0 & 64 & 106 & 10 & 0 & 0.0974 & 0.0008 \\
\hline & & & & & & & $\mathbf{0}$ & & & & & & & & anufacture of instruments & 0 & 14 & 0 & 0 & 0 & 7 & & 0 & 0 & 14 & 0 & $\mathbf{0}$ & 0.0000 & 0.0000 \\
\hline & & & & & & & 0 & & & & & & & & aintenance and repait of machinery & 72 & 77 & 0 & 0 & 26 & 27 & & 0 & 72 & $n$ & 0 & 0 & 0.0000 & 0.0000 \\
\hline & & & & & & & 0 & & & & & & & & dustries not elsewhere classifiod & 29 & 69 & $\mathbf{0}$ & 0 & 21 & 40 & & $\mathbf{0}$ & 29 & 69 & 0 & 0 & 0.0000 & 0.0000 \\
\hline & & & & & & & 8 & & & & & & & & onstruction & 681 & 681 & 17 & $\mathbf{0}$ & 321 & 321 & & 0 & 681 & 681 & 14 & 0 & 0.0200 & 0.0001 \\
\hline & & & & & & & 51 & & & & & & & & olght transport and cornmunication & 138 & 292 & 122 & 1 & 49 & 122 & & 0 & 138 & 292 & 97 & 1 & 0.3329 & 0.0023 \\
\hline & & & & & & & 14 & & & & & & & & ommerce & 96 & 347 & 32 & 0 & 34 & 155 & & 0 & 96 & 348 & 26 & 0 & 0.0737 & 0.0006 \\
\hline & & & & & & & 4 & & & & & & & & estaurants & 79 & 79 & 7 & 0 & 44 & 44 & & 0 & 79 & 79 & 6 & 0 & 0.0737 & 0.0006 \\
\hline & & & & & & & 3 & & & & & & & & assenger transport & 46 & 78 & 9 & 0 & 16 & 29 & & 0 & 46 & 78 & 7 & 0 & 0.0908 & 0.0007 \\
\hline & & & & & & & 10 & & & & & & & & Iblic utilities and sorvices to houso & 244 & 305 & 26 & 0 & 88 & 110 & & 0 & 244 & 305 & 21 & 0 & 0.0691 & 0.0005 \\
\hline & & & & & & & 20 & & & & & & & & shural. education and health services & 518 & $620^{\circ}$ & 54 & 0 & 183 & 226 & & $\mathbf{0}$ & 518 & 620 & 43 & 0 & 0.0691 & 0.0005 \\
\hline & & & & & & & 6 & & & & & & & & nance and insurance & 6 & 161 & 14 & 0 & 2 & 75 & & $\mathbf{0}$ & 6 & 162 & 11 & 0 & 0.0691 & 0.0005 \\
\hline & & & & & & & 6 & & & & & & & & blic administration & 212 & 212 & 18 & 0 & 75 & 75 & & 0 & 212 & 212 & 15 & 0 & 0.0691 & 0.0005 \\
\hline & & & & & & & & & & & & & & & $\mathrm{Ha}$ & 4.704 & 9.247 & 3,485 & 27 & 2,080 & 4,240 & 1,62 & 13 & 4,687 & 9,247 & 587 & 20 & & \\
\hline
\end{tabular}

Final Demand and Gross Output in billions of 1990 Yuans

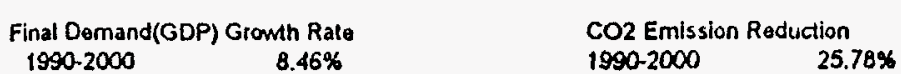


growth in GDP is also slightly decreased from 8.50 to $8.46 \%$, and gross output is essentially the same as the baseline. The sectors whose gross output increases or decreases the most are the same as those found for the with constraint case (Table 40), although the absolute value of the changes is lower.

An interesting aspect of these results is that all energy-use coefficients were decreased by $20 \%$, which should yield the target $20 \%$ reduction in $\mathrm{CO}_{2}$ emissions, as well as emissions of all other pollutants. However, these results indicate a $25.78 \%$ decrease in $\mathrm{CO}_{2}$, which is attributable to negative multiplier effects associated with the reduction in energy production. Offsetting this fact is that improvements in energy efficiency essentially reduce the effective price of energy, thus making it more attractive. Therefore, the implicit penalty against energy-intensive goods is eased, and there is some substitution toward them (somewhat the reverse of Strategy 1). This phenomenon is well acknowledged in the literature (Khazzoom 1993; Rose and Lin 1994). However, in the simulation, this incentive effect is relatively weak. This fact also pertains to the $(5 \%)$ with constraint case.

\subsubsection{Strategy 3: Interfuel Substitution with Current Technology}

Simulating the impacts of interfuel substitution uses the baseline technology and focuses on the response to changes in the relative attractiveness of various fuels due to either direct or social costs (e.g., environmental externalities), subject to fuel availability constraints. As such, both interfossil fuel substitution and the substitution of other forms of energy (predominantly hydro and nuclear) are considered for fossil fuels. The technological and fuel use availability parameters are those developed in the previous section and are reproduced in Table 42 .

Interfuel substitution possibilities exist in several sectors besides electricity services, but only to a limited degree. The use of coal in many sectors of China's economy is a prime candidate for displacement by electricity, but this consideration is grouped in the category of technological change simulated in Strategy 4. Otherwise, substitution possibilities are quite limited. Increased use of oil is not a viable option. Small amounts of gas or electricity could be substituted for oil (most oil outside of electricity services is used for lubricants and transportation fuels). Therefore, this section focuses on interfuel substitution in electricity services, which is the largest consumer of primary energy. The result can be generalized to interfuel substitution in other sectors, and the model presented in this report can be modified to explicitly analyze interfuel substitution in several sectors simultaneously.

Various possibilities for interfuel substitution are present. For example, projections for the year 2000 show sufficient gas reserves to generate all electricity needs in China. Also, the combination of hydro and nuclear resources is adequate to fill most of the needed capacity (Section 5). Of course, considerations of investment requirements and fuel mix diversity need to be taken into account. Accordingly, some limits were placed on the extent of substitution away from coal and oil toward natural gas and hydro/nuclear in the electricity services sector. The new mix is presented in column 2 of Table 43 and can be compared with the baseline 
TABLE 42 Potential for Clean Fuels in Electricity Generation: Upper-Bound Parameters

\begin{tabular}{|c|c|c|c|c|c|}
\hline No. & Parameter & 1990 & 2000 & 2010 & 2025 \\
\hline 1. & $\begin{array}{l}\text { Upper-bound baseline } \\
\text { electricity demand (billion } \\
1990 \text { yuan) }\end{array}$ & 65.146 & 142.000 & 292.000 & 750.000 \\
\hline $2 a$. & $\begin{array}{l}\text { Hydropower potential } \\
\text { (billion } 1990 \text { yuan) }\end{array}$ & 13.051 & 24.446 & 45.825 & 117.556 \\
\hline $2 b$. & $\begin{array}{l}\text { Nuclear power potential } \\
\text { (billion } 1990 \text { yuan) }\end{array}$ & 0.191 & 1.845 & 17.795 & 532.981 \\
\hline 2c. & $\begin{array}{l}\text { Gas-fired electricity } \\
\text { potential (billion } 1990 \text { yuan) }\end{array}$ & 0.268 & 71.000 & 124.108 & 94.134 \\
\hline 3. & $\begin{array}{l}\text { Total of } 2 \mathrm{a}-2 \mathrm{c} \text { baseline } \\
\text { demand }(\%)\end{array}$ & 20.740 & 68.510 & 64.290 & 99.290 \\
\hline 4. & $\begin{array}{l}\text { Effective } \mathrm{CO}_{2} \text { reduction } \\
\text { requirement }(\%)\end{array}$ & $\mathrm{NA}^{\mathrm{a}}$ & 5.000 & 57.300 & 83.910 \\
\hline 5. & $\begin{array}{l}\text { Maximum } \mathrm{CO}_{2} \text { reduction } \\
\text { attainable with clean fuels } \\
\text { in electricity generation }(\%)\end{array}$ & $\mathrm{NA}$ & 24.200 & 23.840 & 90.100 \\
\hline
\end{tabular}

a $\mathrm{NA}=$ not applicable.

TABLE 43 Percentage of Electricity Sector Fuel Mix: Upper-Bound Values

\begin{tabular}{lrrrr}
\hline \multicolumn{1}{c}{ Fuel } & 1990 & 2000 & 2010 & 2025 \\
\hline Coal & 70.27 & 28.20 & 34.10 & 0.00 \\
Oil & 7.30 & 3.30 & 1.60 & 0.70 \\
Natural gas & 0.41 & 50.00 & 42.50 & 12.86 \\
Other (hydro and nuclear) & 20.03 & 18.50 & 21.80 & 86.70 \\
\hline
\end{tabular}


requirements in column 1 of that table. ${ }^{14}$ Rather than choose a fuel mix that simply meets the $5 \% \mathrm{CO}_{2}$ reduction criterion in the electricity services sector, this study chose the one that achieves the maximum reduction possible in that sector $-24.20 \%$ in the year $2000 .^{15}$

The results of a simulation of interfuel substitution to meet the $5 \% \mathrm{CO}_{2}$ emission reduction target in the year 2000 are presented in Table 44. Under this strategy, the GDP grows by only $8.51 \%$ rather than by the $8.50 \%$ baseline estimate. An interesting feature of this simulation is that the overall $\mathrm{CO}_{2}$ emission reduction is 216 million tons, but the electricity services sector achieves a reduction of 269 million tons. As a result, this sector's actions enable some more polluting sectors to expand their output under the with constraint scenario. (This scenario is not the case when the constraint is dropped.) The gross output of all sectors, except coal mining, increases over baseline levels. In fact, the sum of sectoral gross output levels is $4.5 \%$ higher than baseline. However, the GDP (total final demand) is essentially the same.

The maximum attainable mitigation under Strategy 3 leads to a $9.07 \% \mathrm{CO}_{2}$ emission reduction (Table 45). Overall, 269 million of the 316 million tons of $\mathrm{CO}_{2}$ mitigation stem from the electricity services sector and the rest from a change in the economywide sectoral mix. Most of the latter comes from a reduction in coal mining. Petroleum and other mining gross output increases, which reflects the interfuel substitution modeled. The gross output of all other sectors is virtually unchanged.

Strategy 3 yields an improvement of more than 0.05 percentage points in the economic growth rate over Strategy 1 , in which the $\mathrm{CO}_{2}$ emission reduction had to be met entirely by changes in the sectoral mix. Strategy 3 would also yield the additional benefit of a $9.43 \%$ decrease in $\mathrm{SO}_{\mathrm{x}}$.

${ }^{14}$ Even the electricity sector simulations did not require the use of the formal fuel choice (LP) submodel. The attainment of a least-cost mix of fuel subject to a single constraint is simply a costeffectiveness exercise - the lowest cost fuel is used up to its constraint level; the next least costly fuel is used up to its constraint level, etc. Under the assumption of equal annual fuel costs (combined capital and operating), all choices are arbitrary, ceteris paribus. However, various considerations need to be taken into account such as the relative ease of converting power plants from coal to gas compared with building new nuclear or hydro facilities, but keeping in mind limitations on how quickly the conversion process can take place (recall the discussion in Section 5). Thus, for the year 2000 , coal use is displaced by natural gas up to $50 \%$, which is less than its potential of $60.4 \%$. Nuclear and hydro are substituted for coal up to their availability limits. Similar procedures are used for subsequent years. The constraints for additional GHGs would require the use of a formal LP model. Also, for example, a $\mathrm{CH}_{4}$ emission constraint would tip the balance from natural gas toward nuclear and hydro.

15 Strategies such as mandated conservation, interfuel substitution, and technological change manifest themselves in changes in $\mathrm{CO}_{2}$ (and $\mathrm{SO}_{\mathrm{x}}$ ) emission coefficients in the right columns of the various tables. For the case of interfuel substitution, only the electricity services sector emission coefficients change. 
TABLE 44 Simulation Results: China DLP Model 3-U (1990-2000)

1 Agricultura

2 Coal mining

3 Crudo petroleum \& natural gas prod

Motal ore mining

Food manulacluring

Manulacture of lextilos

Sawmills and manufacture of furniture

Manufacture of paper and oduc materia

Elocticily, sleam and hol waler prod

12 Petroloum refineries

13 Coking. manulacture of gas \& coal

1 Chemical industies

is Manufactura of building materials

16 Primary metal manulacluring

17 Manufaclure of melal producis

18 Manulacture of machinary

19 Manufaclute of transport equipmen

20 Manufacture of electric machinery

21 Manulacture of electronics equip

22 Manufaclure of instruments

23 Maintenance and repair od machinery

24. Industries not olsewtioro classified

25 Construction

26 Freight transport and communication

27. Commerca

28 Restautants

29 Passangar transport

30 Public ulititios and servicas la house

Cullural, oducation and healh sorvicos

32 Finance and insurance

Total 4,704

\begin{tabular}{|c|c|c|c|c|c|c|c|c|c|c|c|c|c|}
\hline \multirow{2}{*}{$\begin{array}{l}\text { BASELINE } \\
\frac{2000}{\text { Final }} \\
\text { Demand }\end{array}$} & \multirow[b]{2}{*}{$\begin{array}{l}\text { Gross } \\
\text { Output }\end{array}$} & \multirow[b]{2}{*}{$\begin{array}{c}\mathrm{CO2} \\
\text { (MIL TON) }\end{array}$} & \multirow[b]{2}{*}{$\begin{array}{l}\mathrm{SO} 2 \\
\text { MLL TON) }\end{array}$} & \multirow{2}{*}{$\begin{array}{c}\text { DLP } \\
1990 \\
\text { Final } \\
\text { Demand }\end{array}$} & \multirow[b]{2}{*}{$\begin{array}{l}\text { Gross } \\
\text { Oulput }\end{array}$} & \multirow[b]{2}{*}{$\begin{array}{c}\mathrm{CO2} \\
\text { MUL TON) }\end{array}$} & \multirow[b]{2}{*}{$\begin{array}{c}\mathrm{SO2} \\
\text { (Mil. TON) }\end{array}$} & \multicolumn{4}{|l|}{$\begin{array}{l}\text { DLP } \\
2000\end{array}$} & \multirow{2}{*}{$\begin{array}{c}\mathrm{CO} 2 \\
\text { COEFFICIENT } \\
\text { (TONITO YUAN) }\end{array}$} & \multirow{2}{*}{$\begin{array}{c}\text { SO2 } \\
\text { COEFFICIENT } \\
\text { (TONTHO YUAN) }\end{array}$} \\
\hline & & & & & & & & $\begin{array}{c}\text { Final } \\
\text { Domand }\end{array}$ & $\begin{array}{l}\text { Gross } \\
\text { Oulpul }\end{array}$ & $\begin{array}{c}\mathrm{CO} 2 \\
\text { MIL TON) }\end{array}$ & $\begin{array}{c}\mathrm{SO} 2 \\
\text { (MNL TON) }\end{array}$ & & \\
\hline 1.387 & 2.171 & 121 & 1 & 491 & 879 & 49 & 0 & 1,367 & 2,171 & 121 & 1 & 0.0557 & 0.0004 \\
\hline 31 & 108 & 352 & 3 & 11 & 47 & 153 & 1 & 31 & 94 & 307 & 3 & 3.2568 & 0.0265 \\
\hline 25 & 109 & 23 & 0 & 9 & 46 & 10 & 0 & 25 & 120 & 28 & 0 & 0.2141 & 0.0005 \\
\hline 0 & 28 & 0 & 0 & 0 & 14 & 0 & 0 & 0 & 28 & 0 & 0 & 0.0000 & 0.0000 \\
\hline 0 & 67 & 0 & 0 & 0 & 31 & 0 & 0 & 0 & 73 & 0 & 0 & 0.0000 & 0.0000 \\
\hline 346 & 561 & 115 & 1 & 245 & 353 & 72 & 1 & 348 & 561 & 115 & 1 & 0.2045 & 0.0017 \\
\hline 168 & 502 & 81 & $i$ & 79 & 237 & 38 & 0 & 168 & 502 & B1 & 1 & 0.1615 & 0.0013 \\
\hline 98 & 135 & 0 & 0 & 46 & 63 & 0 & 0 & 98 & 135 & 0 & 0 & 0.0000 & 0.0000 \\
\hline 12 & 65 & 0 & 0 & 8 & 34 & 0 & 0 & 12 & 65 & 0 & 0 & 0.0000 & 0.0000 \\
\hline 42 & 233 & 65 & 1 & 30 & 116 & 32 & 0 & 42 & 233 & 65 & 1 & 0.2799 & 0.0023 \\
\hline 19 & 142 & 1.105 & 9 & 7 & 64 & 499 & 4 & 19 & 141 & 836 & 7 & 5.9237 & 0.0480 \\
\hline 7 & 141 & 92 & 0 & 2 & 61 & 40 & 0 & 7 & 134 & 87 & 0 & 0.6523 & 0.0008 \\
\hline 5 & 18 & 154 & 1 & 2 & 9 & 77 & $i$ & 5 & 18 & 154 & 1 & 8.4178 & 0.0686 \\
\hline 36 & 616 & 342 & 3 & 25 & 287 & 159 & 1 & 36 & 616 & 342 & 3 & 0.5543 & 0.0042 \\
\hline 6 & 250 & 155 & 3 & 2 & 117 & 166 & $i$ & 6 & 250 & 356 & 3 & 1.1199 & 0.0115 \\
\hline 0 & 311 & 266 & 2 & 0 & 161 & 137 & 1 & 0 & 311 & 266 & 2 & 0.8542 & 0.0069 \\
\hline 32 & 148 & 29 & 0 & 23 & 70 & 15 & 0 & 32 & 148 & 29 & 0 & 0.1941 & 0.0016 \\
\hline 174 & 331 & 40 & 0 & 123 & 203 & 25 & 0 & 174 & 332 & 10 & 0 & 0.1218 & 0.0010 \\
\hline 46 & 92 & 11 & 0 & 32 & 54 & 7 & 0 & 46 & 92 & 11 & 0 & 0.1218 & 0.0010 \\
\hline 69 & 159 & 19 & 0 & 48 & 94 & 11 & 0 & 69 & 159 & 19 & 0 & 0.1218 & 0.0010 \\
\hline 78 & 125 & 15 & 0 & 37 & 59 & 7 & 0 & 81 & 128 & 16 & 0 & 0.1218 & 0.0010 \\
\hline 0 & 14 & 0 & 0 & 0 & $y$ & 0 & 0 & 0 & 11 & 0 & a & 0.0000 & 0.0000 \\
\hline 72 & 77 & 0 & 0 & 26 & 27 & 0 & 0 & 72 & 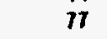 & 0 & 0 & 0.0000 & 0.0000 \\
\hline 29 & 69 & 0 & 0 & 21 & 40 & 0 & 0 & 29 & 69 & 0 & 0 & 0.0000 & 0.0000 \\
\hline 681 & 681 & 17 & 0 & 321 & 321 & 8 & 0 & 681 & 681 & 17 & 0 & 0.0250 & 0.0002 \\
\hline 138 & 292 & 122 & 1 & 49 & 122 & 51 & 0 & 138 & 292 & 121 & 1 & 0.4161 & 0.0029 \\
\hline 96 & 347 & 32 & 0 & 34 & 155 & 14 & 0 & 96 & 347 & 32 & 0 & 0.0921 & 0.0007 \\
\hline 79 & 79 & 7 & 0 & 44 & 44 & 4 & 0 & 79 & 79 & 7 & 0 & 0.0921 & 0.0007 \\
\hline 46 & 78 & 9 & 0 & 16 & 29 & 3 & 0 & 46 & 78 & 9 & 0 & 0.1135 & 0.0009 \\
\hline 244 & 305 & 26 & 0 & 86 & 110 & 10 & 0 & 244 & 305 & 26 & 0 & 0.0864 & 0.0007 \\
\hline 518 & 620 & 54 & 0 & 183 & 226 & 20 & 0 & 518 & 620 & 54 & 0 & 0.0664 & 0.0007 \\
\hline 6 & 161 & 14 & 0 & 2 & 75 & 6 & 0 & 6 & 161 & 14 & 0 & 0.0364 & 0.0007 \\
\hline 212 & 212 & 18 & 0 & 75 & 75 & B & 0 & 212 & 212 & 18 & 0 & 0.0864 & 0.0007 \\
\hline 4,704 & 9.247 & 3,485 & 27 & 2,080 & 4,240 & 1,620 & 13 & 4,707 & 9.247 & 3.169 & 24 & & \\
\hline
\end{tabular}

Finat Demand and Gross Output in billions of 1990 Yuans

Final Demand(GDP) Growth Rate

$1990-2000 \quad 8.51 \%$
CO2 Emission Reduction

$1990.2000 \quad 9.07 \%$ 
TABLE 45 Simulation Results: China DLP Model 3-U (1990-2000), with Constraint

1 Agriculturo

2 Coal mining

3 Crude pelroleum \& natural gas prod

Motal ore mining

5 Other mining

6 Food manulacluring

Manulacture of textilos

Manulacture or apparel

Sawmilis and manulacture of furniture

10 Manulacture of paper and oduc matoria

11 Electricity, sleam and hol waler prod

12 Pelroleum refineries

13 Coking. manulacture of gas \& coal

15 Manulacture of building malerials

16 Primary metal manufacturing

17 Manufacture of motal products

19 Manufacture of transport equipment

20 Manufacture of oloclic machinery

21 Manulacture of electronics equip

22 Manufacturo of insinumenls

23 Maintenance and repair of machinery

24 Indusiries not dlsewhero classified

25 Construction

26 Freight transport and communication

27 Commerce

28 Restaurants

29 Passenger transport

30 Public utilitios and sorvices to houso

31 Cullural, odveation and heath sorvices

32 Finance and insuranco

3 Public administration

rolal 4,704

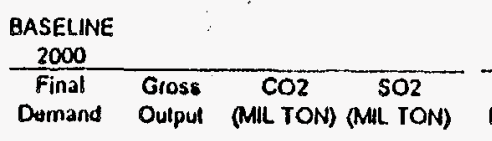

OLP

DLP

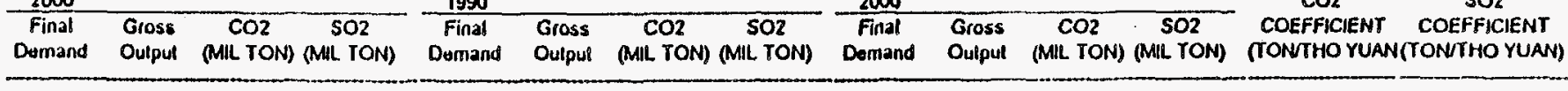

\begin{tabular}{|c|c|c|c|c|c|c|c|c|c|c|c|c|}
\hline \multirow{3}{*}{$\begin{array}{r}1,387 \\
31 \\
31\end{array}$} & 2.171 & 121 & 1 & 491 & 879 & 49 & 0 & 8.307 & 2,269 & 126 & 1 & 0.0551 \\
\hline & 108 & 352 & 3 & 11 & 47 & 153 & 1 & 31 & 99 & 321 & 3 & 3.2568 \\
\hline & 109 & 23 & 0 & 9 & 46 & 80 & 0 & 25 & 125 & 27 & 0 & 0.2141 \\
\hline
\end{tabular}

0
0 67

$346 \quad 56$

168502

98.135

$42 \quad 233$

$5 \quad 18$

$\begin{array}{rrr}36 & 616 & 342 \\ 6 & 250 & 355\end{array}$

$\begin{array}{lll}0 & 311 & 355 \\ 32 & 149 & 266\end{array}$

$\begin{array}{rrr}32 & 148 & 29 \\ 174 & 331 & 40\end{array}$

$46 \quad 92$

$\begin{array}{lll}0 & 123 & 203 \\ 0 & 32 & 54\end{array}$

$\begin{array}{llllll}78 & 159 & 19 & 0 & 48 & 94 \\ & 125 & 15 & 0 & 37 & 59\end{array}$

$\begin{array}{rrrrrr}0 & 14 & 0 & 0 & 0 & \\ 72 & 17 & 0 & 0 & 26 & 27 \\ 29 & 69 & 0 & 0 & 21 & 40\end{array}$

$\begin{array}{rrrrrr}29 & 69 & 0 & 0 & 21 & 40 \\ 681 & 681 & 17 & 0 & 321 & 321\end{array}$

$\begin{array}{rrrrrr}138 & 292 & 122 & 1 & 49 & 122 \\ 96 & 347 & 32 & 0 & 34 & 155\end{array}$

$\begin{array}{rrrrrr}96 & 347 & 32 & 0 & 34 & 155 \\ 79 & 79 & 7 & 0 & 44 & 44\end{array}$

$\begin{array}{rrrrrr}46 & 78 & 9 & 0 & 16 & 29 \\ 244 & 305 & 26 & 0 & 86 & 110\end{array}$

$\begin{array}{rrrrrr}518 & 620 & 54 & 0 & 86 & 110 \\ 6 & 161 & 11 & 0 & 2 & 226 \\ 212 & 212 & 11 & 0 & 75 & 75\end{array}$

$212 \quad 212 \quad 18$

27.080

$\begin{array}{rrr}1.240 & 1,620 & 0 \\ 0 & 13\end{array}$

$4,706 \quad 9,661$

$0.2141 \quad 0.0005$

$0.0000 \quad 0.0000$

$0.0000 \quad 0.0000$

$0.2045 \quad 0.0017$

$0.1615 \quad 0.0013$

$0.0000 \quad 0.0000$

$\begin{array}{ll}0.0000 & 0.0000 \\ 0.2799 & 0.0023\end{array}$

$5.9237 \quad 0.0480$

$0.6523 \quad 0.0000$

$\begin{array}{ll}0.4518 & 0.0686 \\ 0.5543 & 0.0042\end{array}$

$1.4199 \quad 0.0115$

$0.8542 \quad 0.0069$

0.0016

$0.1218-0.0010$

$0.1218-0.0010$

$0.1218-0.0010$

$0.1210 \quad 0.0010$

0.00000 .00000

$0.0000 \quad 0.0000$

Final Demand and Gross Output in billions of 1990 Yuans

Final Domand(GDP) Growh Rale

CO2 Emission Reduction

$1990-2000 \quad 8.51 \%$

1990-2000 5.00\% 


\subsubsection{Strategy 4: Interfuel Substitution with Technological Advances}

The technological advances (change) strategy combines three phenomena: (1) changes in the overall energy/GDP ratio; (2) electrification or, more specifically in the case of China, displacement of coal by electricity for a range of uses in industry; and (3) AEEI. ${ }^{16}$ The parameters associated with each of these considerations are those developed in Section 5 and are reproduced in Table 46.

It is assumed that no change in the energy/GDP ratio in China will occur over the next 30 years because of offsetting forces, quite apart from autonomous conservation. This study also assumes no cost penalty for the various technological changes because of factors noted in conjunction with Strategy 3. In electrification, large central power stations can generate electricity (for power, heat, etc.) at much less cost than numerous small-scale operations in industry.

Table 47 presents the results of simulating Strategy 3 without limiting $\mathrm{CO}_{2}$ emission reductions to $5 \%$ in the year 2000. The average rate of growth and GNP is projected to be $8.59 \%$ as a result of this strategy. This fact highlights that electrification and autonomous conservation have substitution and multiplier effects that actually stimulate the economy. Moreover, the technological change strategy reduces $\mathrm{CO}_{2}$ by $30.59 \%$ from the year 2000 baseline projections.

\section{TABLE 46 Percentage of Technological Change in Energy Use: Upper-Bound Parameters}

\begin{tabular}{|c|c|c|c|}
\hline Parameter & $1990-2000$ & $2000-2010$ & 2010-2025 \\
\hline \multicolumn{4}{|l|}{ Electricity/GDP ratio } \\
\hline Annual average & 0 & 0 & 0 \\
\hline Period total & 0 & 0 & 0 \\
\hline \multicolumn{4}{|c|}{ Displacement of coal ${ }^{\mathrm{a}}$} \\
\hline Annual average & 0.96 & 5.40 & 1.22 \\
\hline Period total & 10.00 & 70.00 & 20.00 \\
\hline \multicolumn{4}{|c|}{ Autonomous conservation ${ }^{b}$} \\
\hline Annual average & 2.50 & 1.50 & 1.00 \\
\hline Period total & 28.01 & 16.05 & 10.46 \\
\hline \multicolumn{4}{|c|}{$\begin{array}{l}\text { Applies to all sectors, except fabricated metals and electricity } \\
\text { services. }\end{array}$} \\
\hline \multicolumn{4}{|c|}{ b Applies to all sectors, except electricity services. } \\
\hline
\end{tabular}

${ }^{16}$ A similar concept was considered in mandated, or autonomous, conservation in Strategy 2. 
TABLE 47 Simulation Results: China DLP Model 4-U (1990-2000), with Constraint

\begin{tabular}{|c|c|c|c|c|c|c|c|c|c|c|c|c|c|c|}
\hline \multirow[b]{3}{*}{ Agriculture } & \multirow{3}{*}{$\begin{array}{c}\begin{array}{c}\text { Baseline } \\
2000\end{array} \\
\begin{array}{c}\text { Final } \\
\text { Domand }\end{array} \\
1,387\end{array}$} & \multirow{3}{*}{$\begin{array}{c}\begin{array}{c}\text { Gross } \\
\text { Output }\end{array} \\
2,171\end{array}$} & \multirow{3}{*}{$\frac{\begin{array}{c}\mathrm{CO} 2 \\
\text { (mil ton) }\end{array}}{121}$} & \multirow[b]{2}{*}{$\begin{array}{c}\mathrm{SO} 2 \\
\text { (mil ton) }\end{array}$} & \multirow{2}{*}{$\begin{array}{c}\text { DLP } \\
1990 \\
\text { Final } \\
\text { Demand }\end{array}$} & \multirow[b]{2}{*}{$\begin{array}{l}\text { Gross } \\
\text { Oulput }\end{array}$} & \multirow[b]{2}{*}{$\begin{array}{c}\mathrm{CO} 2 \\
\text { (mil ton) }\end{array}$} & \multirow[b]{2}{*}{$\begin{array}{c}\mathrm{SO}^{(m i l} \\
\text { (mon) }\end{array}$} & \multirow{2}{*}{$\begin{array}{c}\text { DLP } \\
2000 \\
\text { Final } \\
\text { Demand }\end{array}$} & \multirow[b]{2}{*}{$\begin{array}{l}\text { Gioss } \\
\text { Output }\end{array}$} & \multirow[b]{2}{*}{$\underset{\text { (mil Ion) }}{\mathrm{CO}}$} & \multirow[b]{2}{*}{$\begin{array}{c}\mathrm{SO2} \\
\text { (mil ton) }\end{array}$} & \multirow{2}{*}{$\begin{array}{l}\mathrm{CO} 2 \\
\text { COEFFICIENT } \\
\text { (tor/tho Yuan) }\end{array}$} & \multirow{2}{*}{$\begin{array}{c}\mathrm{SO} 2 \\
\text { COEFFICIENT } \\
\text { (ton/tho Yuan) }\end{array}$} \\
\hline & & & & & & & & & & & & & & \\
\hline & & & & 1 & 491 & 879 & 49 & 0 & 1,376 & 2.981 & 109 & 1 & 0.0366 & 0.0003 \\
\hline 2 Coal mining & 31 & 108 & 352 & 3 & $\|$ & 47 & 153 & 1 & 31 & 112 & 241 & 2 & 2.1546 & $0.01 / 6$ \\
\hline 3 Crude petroleum \& natural gas prod & 25 & 109 & 23 & 0 & 9 & 48 & 10 & o & 25 & 108 & 16 & $\mathbf{0}$ & 0.1515 & 0.0003 \\
\hline 4 Motal oro mining & 0 & 28 & 0 & 0 & $\mathbf{0}$ & 84 & 0 & o & 0 & 41 & 0 & 0 & 0.0000 & 0.0000 \\
\hline Other mining & 0 & 67 & 0 & $\mathbf{0}$ & $\mathbf{0}$ & 31 & 0 & 0 & 0 & 93 & $\mathbf{0}$ & $\mathbf{0}$ & 0.0000 & 0.0000 \\
\hline Food manulacturing & 346 & 561 & 115 & 1 & 245 & 353 & 72 & 1 & 343 & 771 & 102 & 1 & 0.1328 & 0.0011 \\
\hline Manulaclure of rextites & 168 & 502 & 81 & 1 & 79 & 237 & 38 & 0 & 166 & 695 & 73 & 1 & 0.1049 & 0.0000 \\
\hline Manufacture of apparel & 98 & 135 & $\mathbf{0}$ & $\mathbf{0}$ & 46 & 63 & 0 & 0 & 98 & 185 & 0 & $\mathbf{0}$ & 0.0000 & 0.0000 \\
\hline Sawmills and manufacture of furniture & 12 & 65 & $\mathbf{0}$ & $\mathbf{0}$ & 8 & 34 & 0 & $\mathbf{0}$ & 12 & 91 & 0 & 0 & 0.0000 & 0.0000 \\
\hline Manubacture of paper and educ material & 42 & 233 & 65 & 1 & 30 & $\$ 16$ & 32 & 0 & 42 & 323 & 59 & $\mathbf{0}$ & 0.1825 & 0.0015 \\
\hline Electricity, steam and hot water prod & 19 & 142 & 1,105 & 9 & 7 & 64 & 499 & 4 & 19 & 165 & 1.199 & 10 & 7.2834 & 0.0589 \\
\hline Petroleum refineries & 7 & 141 & 92 & 0 & 2 & 61 & 40 & 0 & 7 & 144 & $\pi$ & 0 & 0.5331 & 0.0006 \\
\hline Coking. manufacture of gas \& coal & 5 & 18 & 154 & 1 & 2 & 9 & 77 & 1 & 5 & 21 & 122 & 1 & 5.8870 & 0.0480 \\
\hline Chemical industries & 36 & 616 & 342 & 3 & 25 & 287 & 159 & 1 & 36 & 863 & 319 & 2 & 0.3696 & 0.0028 \\
\hline Manufacture of building materials & 6 & 250 & 355 & 3 & 2 & 117 & 166 & 1 & 6 & 347 & 330 & 3 & 0.9506 & 0.0077 \\
\hline Primary motal manulacturing & 0 & 311 & 266 & 2 & 0 & 161 & 137 & 1 & 0 & 442 & 281 & 2 & 0.6363 & 0.0051 \\
\hline Manufacture of metal products & 32 & 148 & 29 & 0 & 23 & 78 & 15 & 0 & 32 & 204 & 26 & 0 & 0.1273 & 0.0010 \\
\hline 18 Manulacture of machinery & 174 & 331 & 40 & 0 & 123 & 203 & 25 & 0 & 173 & 460 & 37 & $\mathbf{o}$ & 0.0797 & 0.0006 \\
\hline i9 Manufacture of transport oquipment & 46 & 92 & 11 & 0 & 32 & 54 & 7 & 0 & 91 & 199 & 16 & 0 & 0.0795 & 0.0006 \\
\hline 20 Manutacture of electric machinery & 69 & 159 & 19 & 0 & 48 & 94 & 11 & $\mathbf{0}$ & 68 & 219 & 17 & 0 & 0.0796 & 0.0006 \\
\hline 21 Manufacture of olectronics equip & 78 & 125 & 15 & 0 & 37 & 59 & 7 & 0 & 71 & 159 & 13 & 0 & 0.0793 & 0.0006 \\
\hline 22 Manufacture of instruments & 0 & 14 & 0 & 0 & 0 & 7 & 0 & 0 & 0 & 20 & 0 & 0 & 0.0000 & 0.0000 \\
\hline 23 Maintenance and repair of machinery & 72 & 77 & 0 & 0 & 26 & 27 & 0 & $\mathbf{0}$ & 72 & 106 & $\mathbf{0}$ & 0 & 0.0000 & 0.0000 \\
\hline Industries not elsewhero classified & 29 & 69 & 0 & 0 & 21 & 40 & 0 & $\mathbf{0}$ & 29 & 96 & $\mathbf{0}$ & 0 & 0.0000 & 0.0000 \\
\hline 25 Constuction & 681 & 681 & 17 & 0 & 321 & 321 & 8 & o & 675 & 932 & 15 & 0 & 0.0186 & 0.0001 \\
\hline Freight transport and communication & 138 & 292 & 122 & 1 & 49 & 122 & 51 & 0 & 137 & 402 & 114 & 1 & 0.2842 & 0.0020 \\
\hline Commerce & 96 & $\mathbf{3 4 7}$ & 32 & 0 & 34 & 155 & 14 & 0 & 95 & 481 & 29 & 0 & 0.0601 & 0.0005 \\
\hline Restaurants & 79 & 79 & 7 & $\mathbf{0}$ & 44 & 44 & 4 & 0 & 78 & 108 & 6 & 0 & 0.0600 & 0.0005 \\
\hline Passenget transport & 46 & 78 & $\mathbf{g}$ & 0 & 16 & 29 & $\mathbf{3}$ & 0 & 46 & 107 & 8 & 0 & 0.0766 & 0.0006 \\
\hline Public utilities and services to house & 244 & 305 & 26 & 0 & 86 & 110 & 10 & 0 & 242 & 418 & 24 & 0 & 0.0570 & 0.0004 \\
\hline Cuttural, oducation and health services & 518 & 620 & 54 & 0 & 183 & 226 & 20 & 0 & 514 & 851 & 48 & 0 & 0.0569 & 0.0004 \\
\hline Finance and Insurance & 6 & 161 & 14 & 0 & 2 & 75 & 6 & 0 & 6 & 224 & 13 & 0 & 0.0564 & 0.0004 \\
\hline Public administration & 212 & 212 & 18 & 0 & 75 & 75 & 6 & 0 & 211 & 291 & 17 & 0 & 0.0569 & 0.0004 \\
\hline Total & 4.704 & 9,247 & 3.485 & 27 & 2,080 & 4.240 & 1,620 & 13 & 4,710 & 12,656 & 3,311 & 26 & & \\
\hline
\end{tabular}

Final Demand and Gross Output in billions of 1990 Yuans

$\begin{array}{cccc}\text { Final Demand(GDP) Growth Rate } & \text { CO2 Emisslon Roduction } \\ 1990-2000 & 8.52 \% & 1990-2000 & 5.00 \%\end{array}$ 
Table 48 presents the results of the strategy simulation with constraint. As in Strategy 3 , the minimal $\mathrm{CO}_{2}$ emission reduction target is easily attained and allows the economy to adjust its output mix accordingly to maximize the GDP. In fact, the gross output of every sector is higher than the baseline.

\subsubsection{Strategy 5: Combination of Strategies}

The modest $\mathrm{CO}_{2}$ reduction target of $5.0 \%$ in the year 2000 can be attained by any of the first four strategies. A combination of strategies 1-4 is not required, although this option is available. However, it would also appear that the vastly superior option is Strategy 4, which can attain higher $\mathrm{CO}_{2}$ (and $\mathrm{SO}_{\mathrm{x}}$ ) emission reductions than the other strategies and still increase the rate of economic growth.

\subsubsection{Summary}

Table 49 summarizes the results of this section. On the basis of relatively optimistic economic and technical assumptions, the modest $\mathrm{CO}_{2}$ reduction requirement of $5 \%$ for the year 2000 is readily attainable by each of the four major strategies. Moreover, only the sectoral mix in mandated conservation strategies imposes any penalties, and these are relatively modest. Moreover, the $\mathrm{CO}_{2}$ reduction efforts also yield approximately equivalent reductions in $\mathrm{SO}_{2} \cdot{ }^{17}$

\subsection{SIMULATIONS FOR 2010 AND 2025: UPPER-BOUND CASE}

\subsubsection{Year 2010}

Table 50 summarizes the results of simulating the five strategies. First, the effective emission reduction requirement increases significantly in 2010 (i.e., $57.30 \%$ ). This result is a combination of the fact that (1) baseline $\mathrm{CO}_{2}$ emissions increase by $7.5 \%$ per year (the same growth rate as the GDP) between 2000 and 2010 and (2) the compliance rate jumps from 25 to $60 \%$ of the target cap of 2.788 billion tons of $\mathrm{CO}_{2}$ (Table 38).

These results differ from those for the year 2000 in several ways. First, none of the singular strategies (1-4) can meet the $57.30 \% \mathrm{CO}_{2}$ mitigation target, except Strategy 1 (when fewer constraints on the final demand are imposed). Because these strategies cannot meet the $\mathrm{CO}_{2}$ constraint, they are labeled as "infeasible." Table 50 indicates that the maximum achievable $\mathrm{CO}_{2}$ reductions are $35.23,8.62$, and $53.19 \%$ for strategies 2,3 , and 4 , respectively. The interfuel substitution strategy (Strategy 3 ) is especially limited for the year 2000 because

17 This result is true of all major air pollutants discussed in Section 5, although $\mathrm{CH}_{4}$ emissions increase, given the sizable gas utilization associated with Strategy 3. 
TABLE 48 Simulation Results: China DLP Model 3-U (1990-2000), with Constraint

1 Agriculture

3 Crude petroloum \& natural gas prod

4 Metal oro mining

5 Other mining

6 Food manufacturing

Manulacture of textiles

Manutacture of apparel

Sawmills and manufacture of humiture

to Manufacture of paper and oduc material

11 Electricity, steam and hot water prod

12 Petroleum refineries

13 Coking. manutacture of gas $\&$ coal

14 Chemical industries

15 Manufacture of building materials

16 Primary motal manufacturing

17 Manutacture of metal products

18 Manufacture of machinery

19 Manufacture of transport equipment

20 Manufacture of electric machinery

21 Manufacture of electronics equip

22 Manufacture of instrumants

23 Maintenance and repair of machinery

24 Industries not alsewhere classified

25 Construction

26 Froight transport and communication

27 Commerce

28 Restaurants

29 Passonger transport

30 Public utilities and services to house

31 Cultural, education and health services

32 Finance and insurance

3 Public administration

Total

Baseline
2000

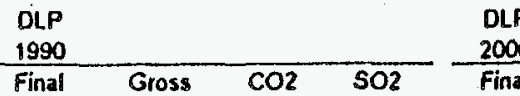

\begin{tabular}{l} 
DLP \\
2000 \\
\hline
\end{tabular}

(mil ton) (mil ton) Domand Output (mil ton) (mil (on)

$\mathrm{CO} 2$ COEFFICIENT COEFFICIENT

(491- O

121

$\begin{array}{rrr}25 & 109 & 23 \\ 0 & 28 & 0\end{array}$

$0.67 \quad 0$

$346.561 \quad 115$

$98 \quad 135$

$12 \quad 65$

$19 \quad 652 \quad 65$

$142 \quad 1.105$

$\begin{array}{rrr}7 & 141 & 92 \\ 5 & 18 & 154\end{array}$

$\begin{array}{lll}36 & 616 & 342 \\ 6 & 250 & 355\end{array}$

$\begin{array}{rrr}0 & 311 & 266 \\ 32 & 148 & 29\end{array}$

$174 \quad 331 \quad 40$

46

69
78

$\begin{array}{rr}92 & 11 \\ 159 & 19\end{array}$

125 . 15

$\begin{array}{lll}14 & 0 & 0\end{array}$

29

681
138

138
96

96
79

$46 \quad 78$

$244 \quad 305 \quad 26$

$518 \quad 620 \quad 54$

$\begin{array}{llll}6 & 161 & 14 & 0\end{array}$

4.704

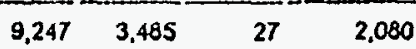

$2,0 8 0 \longdiv { 4 , 2 4 0 } - 1,620$

13

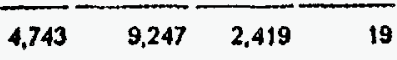

Final Dernand and Gross Output in billions of 1990 Yuans

$\begin{array}{cccc}\text { Final Demand(GOP) Growth Rate } & \text { CO2 Emission Reduction } \\ 1990-2000 & 8.59 \% & 1990-2000 & 30.59 \%\end{array}$


TABLE 49 Summary of Simulation Results, Year 2000:

Upper-Bound Case ${ }^{a}$

\begin{tabular}{|c|c|c|c|}
\hline Simulation & $\begin{array}{l}\text { GNP } \\
\text { Growth } \\
(\%)\end{array}$ & $\begin{array}{c}\mathrm{CO}_{2} \\
\text { Emission } \\
\text { Reduction } \\
\quad(\%)\end{array}$ & $\begin{array}{c}\mathrm{SO}_{2} \\
\text { Emission } \\
\text { Reduction } \\
(\%)\end{array}$ \\
\hline Baseline & 8.50 & $\mathrm{NA}^{\mathrm{b}}$ & NA \\
\hline $\begin{array}{l}\text { Change in sectoral mix } \\
\text { With constraint } \\
\text { Without constraint }\end{array}$ & $\begin{array}{l}8.46 \\
\text { NA }\end{array}$ & $\begin{array}{l}5.00 \\
\text { NA }\end{array}$ & $\begin{array}{l}5.09 \\
\text { NA }\end{array}$ \\
\hline $\begin{array}{l}\text { Mandated conservation } \\
\text { With constraint } \\
\text { Without constraint }^{d}\end{array}$ & $\begin{array}{l}8.49 \\
8.46\end{array}$ & $\begin{array}{c}5.00 \\
25.78^{f}\end{array}$ & $\begin{array}{c}4.82 \\
24.83\end{array}$ \\
\hline $\begin{array}{l}\text { Interfuel substitution } \\
\text { With constraint } \\
\text { Without constraint } \\
\text { di }\end{array}$ & $\begin{array}{l}8.51 \\
8.51\end{array}$ & $\begin{array}{l}5.00 \\
9.07^{\mathrm{f}}\end{array}$ & $\begin{array}{l}5.20 \\
9.43\end{array}$ \\
\hline $\begin{array}{l}\text { Technological change } \\
\text { With constraint }{ }^{\mathrm{d}} \\
\text { Without constraint }\end{array}$ & $\begin{array}{l}8.52 \\
8.59\end{array}$ & $\begin{array}{c}5.00 \\
30.59^{f}\end{array}$ & $\begin{array}{c}4.98 \\
30.47\end{array}$ \\
\hline Combination ${ }^{\mathrm{g}}$ & NA & NA & NA \\
\hline
\end{tabular}

a $\mathrm{CO}_{2}$ reduction target: $20 \%$ of year 2000 baseline emissions, but only $25 \%$ compliance, which translates into $5 \%$ of year 2000 emissions.

b $\mathrm{NA}=$ not applicable.

c Constraint that sets limits on changes in sectoral output levels.

d Constraint that requires $\mathrm{CO}_{2}$ emissions be reduced by $5 \%$ - of year 2000 baseline.

e Loosens constraint on sectoral output levels (see text).

$f$ Represents maximum achievable reduction.

g Abatement target can be achieved by every other strategy; hence, examination of a combination of strategies is redundant. 
TABLE 50 Summary of Simulation Results, Year 2010: Upper-Bound Case ${ }^{a}$

\begin{tabular}{|c|c|c|c|}
\hline Simulation & $\begin{array}{l}\text { GNP } \\
\text { Growth } \\
(\%)\end{array}$ & $\begin{array}{c}\mathrm{CO}_{2} \text { Emission } \\
\text { Reduction } \\
(\%)\end{array}$ & $\begin{array}{c}\mathrm{SO}_{2} \text { Emission } \\
\text { Reduction } \\
(\%)\end{array}$ \\
\hline Baseline & 7.50 & $\mathrm{NA}^{\mathrm{b}}$ & NA \\
\hline $\begin{array}{l}\text { Change in sectoral mix } \\
\text { With constraint } t^{c, d} \\
\text { Without constraint }^{\text {d,e }}\end{array}$ & $\begin{array}{c}\text { Infeasible } \\
2.89\end{array}$ & $\begin{array}{c}\text { NA } \\
57.30\end{array}$ & $\begin{array}{c}\mathrm{NA} \\
58.33\end{array}$ \\
\hline $\begin{array}{l}\text { Mandated conservation } \\
\text { With constraint } \\
\text { Without constraint }\end{array}$ & $\begin{array}{c}\text { Infeasible } \\
7.49\end{array}$ & $\begin{array}{c}\mathrm{NA} \\
35.23^{\mathrm{f}}\end{array}$ & $\begin{array}{c}\text { NA } \\
35.02\end{array}$ \\
\hline $\begin{array}{l}\text { Interfuel substitution } \\
\text { With constraint } \\
\text { Without constraint }^{\mathrm{d}}\end{array}$ & $\begin{array}{c}\text { Infeasible } \\
\quad 7.50\end{array}$ & $\begin{array}{c}\mathrm{NA} \\
8.62^{\mathrm{f}}\end{array}$ & $\begin{array}{c}N A \\
9.09\end{array}$ \\
\hline $\begin{array}{l}\text { Technological change } \\
\text { With constraint } \\
\text { Without constraint }^{\mathrm{d}}\end{array}$ & $\begin{array}{c}\text { Infeasible } \\
7.50\end{array}$ & $\underset{53.19^{f}}{\mathrm{NA}}$ & $\begin{array}{c}\mathrm{NA} \\
53.74\end{array}$ \\
\hline Combination $^{d}$ & 7.50 & 57.30 & 57.89 \\
\hline
\end{tabular}

a $\mathrm{CO}_{2}$ reduction target: $20 \%$ of year 2000 baseline emissions, but only $60 \%$ compliance, which translates into $57.30 \%$ of year 2010 emissions.

b $\mathrm{NA}=$ not applicable.

c Constraint that sets limits on changes in sectoral output levels.

$\mathrm{d}$ Constraint that requires $\mathrm{CO}_{2}$ emissions be reduced by $57.30 \%$ of year 2010 baseline.

e Loosens constraint on sectoral output levels.

f Represents maximum achievable reduction. 
of the upper bounds included for the available nuclear power (Table 42). In general, strategies are infeasible because of limits in technology and reserves of energy alternatives to coal.

A combination of strategies can attain the $57.30 \%$ level because all are mutually exclusive. ${ }^{18}$ What might a combination of strategies entail? Economic principles suggest that, for a single constraint, decision-makers will exhaust each option in sequence, beginning with the least-cost one and progressing to others also in the least-cost sequence. This principle is illustrated in Figures 3 and 4, which are stylized depictions of the other strategies in terms of constant costs and positioning. Figure 3 represents the direct response in terms of costs at the sectoral level. Conservation is often considered costless or cost-saving, even though if mandated levels are high enough, this would not be the case. Interfuel substitution involves some costs, and technological change often is viewed as costly because it requires new equipment. Strategy 2 (change in the product mix) is not included in Figure 3 because it is not an individual sectoral response.

Interestingly, the positioning of these strategies changes when one considers macro impacts, as indicated by the relative increases or decreases in GDP growth rates (Table 50; these are more dramatically differentiated in Table 51). In this case, technological change is growth enhancing, interfuel substitution growth neutral, and mandated conservation growth dampening. The change in the sectoral mix strategy can be included in the macrolevel case and is also growth dampening.

Figures 3 and 4 can also represent the reaction to both externally imposed reduction requirements ("command-and-control" or standards) or the adjustment to a carbon tax. ${ }^{19}$ The carbon tax would be displayed in Figure 3 as a horizontal line positioned on the vertical axis at a given tax level. The adjustment to the tax is usually analyzed at the micro level, but this report performed a macro analysis, which is more comprehensive. The analysis reveals a positioning of individual strategies that may differ (Rose and Lin 1994). These factors have been taken into account.

Strategy 5 (the combination strategy) for 2010 uses Strategy 4 to its limit and then uses a portion of Strategy 3 to make up the difference between $53.19 \% \mathrm{CO}_{2}$ mitigation and $57.30 \%$. The results indicate that the combination of strategies can reduce $\mathrm{CO}_{2}$ emissions without decreasing economic growth (see the last row in Table 50). Strategy 1 could have attained the $57.30 \%$ emission reduction target, but only at a substantial decrease in economic growth to a level of $2.89 \%$.

Individual sectoral responses in terms of gross output, final demand, $\mathrm{CO}_{2}$ emissions, and $\mathrm{SO}_{\mathrm{x}}$ emissions are displayed in Table 38 .

18 The one exception is mandated conservation (Strategy 2) and AEEIs (Strategy 4) that overlap so much; therefore, Strategy 2 is eliminated from consideration in the combined case.

${ }^{19}$ Pezzey (1990) and Rose et al. (1994) have indicated how response to an international system of marketable permits would be equivalent to that of a carbon tax. 


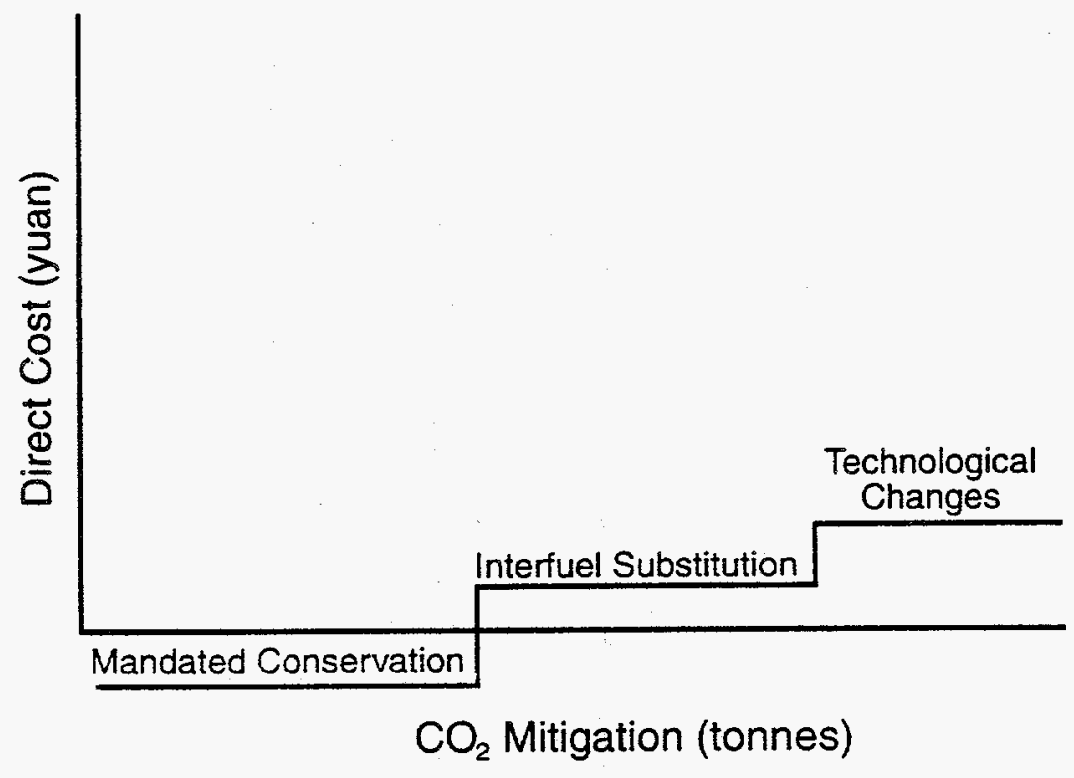

FIGURE 3 Micro Marginal Cost of Strategies

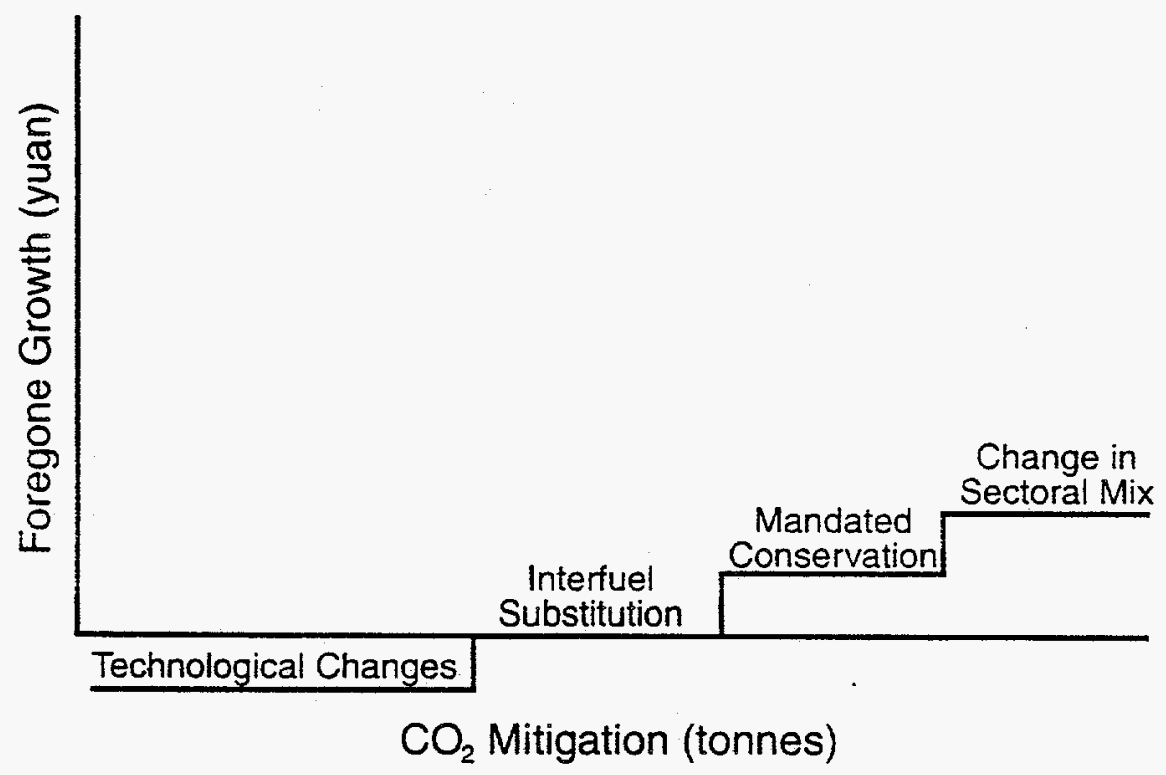

FIGURE 4 Macro Marginal Cost of Strategies 
TABLE 51 Summary of Simulation Results, Year 2025: Upper-Bound Case ${ }^{a}$

\begin{tabular}{|c|c|c|c|}
\hline Simulation & $\begin{array}{l}\text { GNP } \\
\text { Growth } \\
(\%)\end{array}$ & $\begin{array}{c}\mathrm{CO}_{2} \text { Emission } \\
\text { Reduction } \\
(\%)\end{array}$ & $\begin{array}{c}\mathrm{SO}_{2} \text { Emission } \\
\text { Reduction } \\
(\%)\end{array}$ \\
\hline Baseline & 6.50 & $\mathrm{NA}^{\mathrm{b}}$ & NA \\
\hline $\begin{array}{l}\text { Change in sectoral mix } \\
\text { With constraint } t^{c, d} \\
\text { Without constraint }\end{array}$ & $\begin{array}{l}\text { Infeasible } \\
\text { Infeasible }\end{array}$ & $\begin{array}{l}\text { NA } \\
\text { NA }\end{array}$ & $\begin{array}{l}\text { NA } \\
\text { NA }\end{array}$ \\
\hline $\begin{array}{l}\text { Mandated conservation } \\
\text { With constraint } \\
\text { Without constraint } \\
\text { d }\end{array}$ & $\begin{array}{c}\text { Infeasible } \\
6.49\end{array}$ & $\underset{43.31^{f}}{N A}$ & $\begin{array}{c}\mathrm{NA} \\
43.47\end{array}$ \\
\hline $\begin{array}{l}\text { Interfuel substitution } \\
\text { With constraint } \\
\text { Without constraint }^{\mathrm{d}}\end{array}$ & $\begin{array}{c}\text { Infeasible } \\
6.50\end{array}$ & $\begin{array}{c}\mathrm{NA} \\
31.07^{\mathrm{f}}\end{array}$ & $\begin{array}{c}\mathrm{NA} \\
32.91\end{array}$ \\
\hline $\begin{array}{l}\text { Technological change } \\
\text { With constraint } \\
\text { Without constraint }^{\mathrm{d}}\end{array}$ & $\begin{array}{c}\text { Infeasible } \\
6.51\end{array}$ & $\begin{array}{c}\mathrm{NA} \\
62.86^{\mathrm{f}}\end{array}$ & $\underset{63.93}{\mathrm{NA}}$ \\
\hline Combination $^{\mathrm{d}, \mathrm{g}}$ & 6.51 & 84.91 & 86.36 \\
\hline
\end{tabular}

a $\mathrm{CO}_{2}$ reduction target: $20 \%$ of year 2000 baseline emissions and with $100 \%$ compliance; translates into $84.91 \%$ of year 2025 emissions.

b $\mathrm{NA}=$ not applicable.

c Constraint that sets limits on changes in sectoral output levels.

d Constraint that requires $\mathrm{CO}_{2}$ emissions be reduced by $84.91 \%$ of year 2025 baseline.

e Loosens constraint on sectoral output levels.

f Represents maximum achievable reduction.

g Loosens constraint on sectoral output slightly (see text). 


\subsubsection{Year 2025}

Table 51 presents the results of the upper-bound simulations for 2025 . An $84.91 \%$ reduction of the gross flow of year $2025 \mathrm{CO}_{2}$ emissions is required, which is a Herculean task. In fact, none of the strategies is solely capable of meeting the reduction requirement. However, the technological change strategy, together with either the interfuel substitution or mandated conservation strategy, could attain it with little economic penalty. A simulation of a combination of the first two strategies showed that the results are slightly growth enhancing (see the last row in Table 51).

Although the technological change strategy is somewhat more speculative than the others, it becomes less so over time. That is, 30 years should be sufficient for it to be likely to discover major new natural gas deposits, improve combustion efficiency, and reduce the cost and improve the safety features of nuclear power plants.

\subsection{SIMULATIONS FOR 2000, 2010, AND 2025: LOWER-BOUND CASE}

Simulations for the five strategies were performed with the pessimistic, or lowerbound, parameters described in Sections 4 and 5. The major economic parameters are given in Table 37, while the technical parameters are repeated in Tables 52, 53, and 54. The major difference in the economic parameters for the lower-bound cases was a GDP growth rate 1-2\% lower than the optimistic or upper-bound cases. The lower-bound technical parameters call for a natural gas and nuclear potential about $50 \%$ of the upper-bound values, a displacement of coal by electricity to have a saturation level of $70 \%$ rather than $100 \%$, a greater than $1 \%$ increase in the electricity/GDP ratio, and an AEEI 0.5-1.0\% lower than the upper-bound values.

\subsubsection{Year 2000}

Qualitatively, the lower-bound results for the year 2000 are the same as the upperbound cases (compare Tables 55 and 49 ). The $5 \% \mathrm{CO}_{2}$ reduction target can be met with only a very slight reduction in the GDP growth, if any. In fact, Strategy 4 increases the rate of economic growth. The results for mandated conservation are essentially the same (reduction) between upper- and lower-bound cases because they both simulate a direct $20 \%$ reduction in energy use. Strategy 4 (technological change) yields only slightly more than half of the reduction in $\mathrm{CO}_{2}$ than its upper-bound counterpart. Also, reductions in $\mathrm{SO}_{2}$ are very close to the $\mathrm{CO}_{2}$ reduction levels attained.

\subsubsection{Year 2010}

Qualitatively, the results for 2010 are essentially the same as the upper-bound cases (compare Tables 56 and 50). It is worth noting that, in this case, interfuel substitution 
TABLE 52 Potential for Clean Fuels in Electricity Generation: Lower-Bound Parameters

\begin{tabular}{|c|c|c|c|c|c|}
\hline No. & Parameter & 1990 & 2000 & 2010 & 2025 \\
\hline 1. & $\begin{array}{l}\text { Lower-bound baseline } \\
\text { electricity demand } \\
\text { (billion } 1990 \text { yuan) }\end{array}$ & 65.146 & 142.000 & 292.000 & 750.000 \\
\hline $2 a$. & $\begin{array}{l}\text { Hydropower potential } \\
\text { (billion } 1990 \text { yuan) }\end{array}$ & 13.051 & 22.067 & 37.341 & 82.289 \\
\hline $2 \mathrm{~b}$ & $\begin{array}{l}\text { Nuclear power potential } \\
\text { (billion } 1990 \text { yuan) }\end{array}$ & 0.191 & 1.440 & 10.863 & 225.000 \\
\hline 2c. & $\begin{array}{l}\text { Gas-fired electricity } \\
\text { potential (billion } 1990 \\
\text { yuan) }\end{array}$ & 0.268 & 66.963 & 62.075 & 47.067 \\
\hline 3. & $\begin{array}{l}\text { Total } 2 \mathrm{a}-2 \mathrm{c} \text { baseline } \\
\text { demand }(\%)\end{array}$ & 20.740 & 63.710 & 33.770 & 47.320 \\
\hline 4. & $\begin{array}{l}\mathrm{CO}_{2} \text { reduction } \\
\text { requirement }(\%)\end{array}$ & $\mathrm{NA}^{\mathrm{a}}$ & 5.000 & 40.500 & 65.210 \\
\hline 5. & $\begin{array}{l}\text { Maximum } \mathrm{CO}_{2} \text { reduction } \\
\text { attainable with clean } \\
\text { fuels in electricity } \\
\text { generation }(\%)\end{array}$ & NA & 20.130 & 5.480 & 28.340 \\
\hline
\end{tabular}

a $\mathrm{NA}=$ not applicable.

TABLE 53 Percentage of Electricity Sector Fuel Mix: Lower-Bound Values

\begin{tabular}{lrrrr}
\hline \multicolumn{1}{c}{ Fuel } & 1990 & 2000 & 2010 & 2025 \\
\hline Coal & 70.27 & 32.99 & 60.63 & 52.05 \\
Oil & 7.30 & 3.30 & 1.60 & 0.70 \\
Natural gas & 0.91 & 47.16 & 21.26 & 6.28 \\
Other (hydro and nuclear) & 20.03 & 16.55 & 16.51 & 40.97 \\
\hline
\end{tabular}


TABLE 54 Percentage of Technological Change in Energy Use: Lower-Bound Parameters

\begin{tabular}{|c|c|c|c|}
\hline Parameter & $1990-2000$ & $2000-2010$ & $2010-2025$ \\
\hline \multicolumn{4}{|l|}{ Electricity/GDP ratio } \\
\hline Annual average & 1.70 & 1.50 & 1.30 \\
\hline Period total & 18.36 & 16.05 & 21.38 \\
\hline \multicolumn{4}{|c|}{ Displacement of coal ${ }^{a}$} \\
\hline Annual average & 0.96 & 3.42 & 1.22 \\
\hline Period total & 10.00 & 40.00 & 20.00 \\
\hline \multicolumn{4}{|c|}{ Autonomous conservation ${ }^{b}$} \\
\hline Annual average & 1.50 & 1.00 & 0.50 \\
\hline Period total & 16.05 & 10.46 & 7.77 \\
\hline \multicolumn{4}{|c|}{$\begin{array}{l}\text { Applies to all sectors, except fabricated metals and electricity } \\
\text { services. }\end{array}$} \\
\hline \multicolumn{4}{|c|}{ b Applies to all sectors, except electricity services. } \\
\hline
\end{tabular}

possibilities are much more limited and yield less than a $2 \%$ maximum reduction in $\mathrm{CO}_{2}$. Also, Strategy 5 cannot be attained by strategies 3 and 4 alone, as in the upper-bound case. Strategy 1 must be used to attain the last $8.60 \%(40.5 \%-30.01 \%+1.89 \%)$. This decreases economic growth to $3.91 \%$.

\subsubsection{Year 2025}

Qualitatively, the results for 2025 are similar to the corresponding upper-bound cases (compare Tables 57 and 51). However, the growth penalty for Strategy 1 is enormous, and it calls for a 3.92\% reduction in GDP growth between 2010 and 2025.

Again, a combination of strategies 3 and 4 cannot achieve the $\mathrm{CO}_{2}$ reduction target of $65.21 \%$. Thus, there is reason to simulate Strategy 5. Strategy 2 (mandated conservation), is excluded from consideration in the mixed strategy because it would be extremely costly (if not impossible) to implement this strategy. The strategy calls for $10 \%$ conservation from 2010 to 2025 in addition to $30 \%$ between 1990 and 2010, along with an AEEI of $7.77 \%$ for the period in addition to a cumulative AEEI of $26.51 \%$ between 1990 and 2010 (Table 54). The $7.39 \%$ reduction in $\mathrm{CO}_{2}$ attainable by Strategy 3 plus the $34.92 \%$ reduction attainable by Strategy 4 still leaves the country $23 \%$ short of the $65.31 \%$ emission reduction target. Accessing the change in sectoral mix strategy is extremely costly, which reduces economic growth for Strategy 5 to $0.85 \%$. 
TABLE 55 Summary of Simulation Results, Year 2000: Lower-Bound Case ${ }^{\mathrm{a}}$

\begin{tabular}{|c|c|c|c|}
\hline Simulation & $\begin{array}{l}\text { GNP } \\
\text { Growth } \\
(\%)\end{array}$ & $\begin{array}{l}\mathrm{CO}_{2} \\
\text { Emission } \\
\text { Reduction } \\
(\%)\end{array}$ & $\begin{array}{c}\mathrm{SO}_{2} \\
\text { Emission } \\
\text { Reduction } \\
(\%)\end{array}$ \\
\hline Baseline & 6.00 & $\mathrm{NA}^{\mathrm{b}}$ & NA \\
\hline $\begin{array}{l}\text { Change in sectoral mix } \\
\text { With constraint }{ }^{c, d} \\
\text { Without constraint }\end{array}$ & $\begin{array}{l}5.96 \\
\text { NA }\end{array}$ & $\begin{array}{l}5.00 \\
\text { NA }\end{array}$ & $\begin{array}{l}5.15 \\
\text { NA }\end{array}$ \\
\hline $\begin{array}{l}\text { Mandated conservation } \\
\text { With constraint } \\
\text { Without constraint }^{\mathrm{d}}\end{array}$ & $\begin{array}{l}5.99 \\
5.96\end{array}$ & $\begin{array}{c}5.00 \\
25.78^{\text {f }}\end{array}$ & $\begin{array}{r}4.96 \\
25.58\end{array}$ \\
\hline $\begin{array}{l}\text { Interfuel substitution } \\
\text { With constraint }^{\mathrm{d}} \\
\text { Without constraint }^{\mathrm{d}}\end{array}$ & $\begin{array}{l}6.00 \\
6.00\end{array}$ & $\begin{array}{l}5.00 \\
7.62^{f}\end{array}$ & $\begin{array}{l}5.23 \\
7.97\end{array}$ \\
\hline $\begin{array}{l}\text { Technological change } \\
\text { With constraint } \\
\text { Without constraint }^{\mathrm{d}}\end{array}$ & $\begin{array}{l}6.01 \\
6.03\end{array}$ & $\begin{array}{c}5.00 \\
15.54^{\mathrm{f}}\end{array}$ & $\begin{array}{r}4.97 \\
15.46\end{array}$ \\
\hline Combination $^{\mathrm{g}}$ & NA & NA & NA \\
\hline
\end{tabular}

a $\mathrm{CO}_{2}$ reduction target: $20 \%$ of year 2000 baseline emissions, but only $25 \%$ compliance; translates into $5 \%$ of year 2000 emissions.

b $\mathrm{NA}=$ not applicable.

c Constraint that sets limits on changes in sectoral output levels.

d Constraint that requires $\mathrm{CO}_{2}$ emissions be reduced by $5 \%$ of year 2000 baseline.

e Loosens constraint on sectoral output levels.

f Represents maximum achievable reduction.

g Abatement target can be achieved by every other strategy; hence, examination of a combination of strategies is redundant. 
TABLE 56 Summary of Simulation Results, Year 2010: Lower-Bound Case ${ }^{a}$

\begin{tabular}{|c|c|c|c|}
\hline Simulation & $\begin{array}{l}\text { GNP } \\
\text { Growth } \\
(\%)\end{array}$ & $\begin{array}{c}\mathrm{CO}_{2} \text { Emission } \\
\text { Reduction } \\
(\%)\end{array}$ & $\begin{array}{c}\mathrm{SO}_{2} \text { Emission } \\
\text { Reduction } \\
(\%)\end{array}$ \\
\hline Baseline & 4.00 & $\mathrm{NA}^{\mathrm{b}}$ & NA \\
\hline $\begin{array}{l}\text { Change in sectoral mix } \\
\text { With constraint } t^{c, d} \\
\text { Without constraint }\end{array}$ & $\begin{array}{c}\text { Infeasible } \\
3.52\end{array}$ & $\begin{array}{c}\text { NA } \\
40.50\end{array}$ & $\begin{array}{c}\mathrm{NA} \\
41.72\end{array}$ \\
\hline $\begin{array}{l}\text { Mandated conservation } \\
\text { With constraint } \\
\text { Without constraint }\end{array}$ & $\begin{array}{c}\text { Infeasible } \\
3.99\end{array}$ & $\begin{array}{c}\mathrm{NA} \\
35.23^{f}\end{array}$ & $\begin{array}{c}\mathrm{NA} \\
35.02\end{array}$ \\
\hline $\begin{array}{l}\text { Interfuel substitution } \\
\text { With constraint }^{\mathrm{d}} \\
\text { Without constraint }^{\mathrm{d}}\end{array}$ & $\begin{array}{c}\text { Infeasible } \\
4.00\end{array}$ & $\begin{array}{l}\text { NA } \\
1.89^{f}\end{array}$ & $\begin{array}{l}\mathrm{NA} \\
1.87\end{array}$ \\
\hline $\begin{array}{l}\text { Technological change } \\
\text { With constraint }^{\mathrm{d}} \\
\text { Without constraint }^{\mathrm{d}}\end{array}$ & $\begin{array}{c}\text { Infeasible } \\
3.99\end{array}$ & $\begin{array}{c}\text { NA } \\
30.01^{f}\end{array}$ & $\begin{array}{c}\text { NA } \\
30.36\end{array}$ \\
\hline Combination $^{\mathrm{d}}$ & 3.91 & 40.50 & 40.97 \\
\hline
\end{tabular}

a $\mathrm{CO}_{2}$ reduction target: $20 \%$ of year 2000 baseline emissions, but only $60 \%$ compliance; translates into $40.50 \%$ of year 2010 baseline emissions.

b $\mathrm{NA}=$ not applicable.

c Constraint that sets limits on changes in sectoral output levels.

d Constraint that requires $\mathrm{CO}_{2}$ emissions be reduced by $40.50 \%$ of year 2010 baseline.

e Loosens constraint on sectoral output levels.

f Represents maximum achievable reduction. 
TABLE 57 Summary of Simulation Results, Year 2025:

Lower-Bound Case ${ }^{\mathrm{a}}$

\begin{tabular}{|c|c|c|c|}
\hline Simulation & $\begin{array}{l}\text { GNP } \\
\text { Growth } \\
(\%)\end{array}$ & $\begin{array}{c}\mathrm{CO}_{2} \text { Emission } \\
\text { Reduction } \\
(\%)\end{array}$ & $\begin{array}{c}\mathrm{SO}_{2} \text { Emission } \\
\text { Reduction } \\
(\%)\end{array}$ \\
\hline Baseline & 3.00 & $\mathrm{NA}^{\mathrm{b}}$ & NA \\
\hline $\begin{array}{l}\text { Change in sectoral mix } \\
\text { With constraint } \\
\text { Without constraint } \\
\text { Wite }^{\text {d,e }}\end{array}$ & $\begin{array}{c}\text { Infeasible } \\
-3.92\end{array}$ & $\begin{array}{c}\text { NA } \\
65.31\end{array}$ & $\begin{array}{c}\text { NA } \\
67.27\end{array}$ \\
\hline $\begin{array}{l}\text { Mandated conservation } \\
\text { With constraint } \\
\text { Without constraint }^{\mathrm{d}}\end{array}$ & $\begin{array}{c}\text { Infeasible } \\
3.00\end{array}$ & $\underset{43.15^{f}}{\mathrm{NA}}$ & $\begin{array}{c}\text { NA } \\
43.07\end{array}$ \\
\hline $\begin{array}{l}\text { Interfuel substitution } \\
\text { With constraint }^{\mathrm{d}} \\
\text { Without constraint }^{\mathrm{d}}\end{array}$ & $\begin{array}{c}\text { Infeasible } \\
2.99\end{array}$ & $\underset{34.92^{f}}{\mathrm{NA}}$ & $\begin{array}{c}\text { NA } \\
35.37\end{array}$ \\
\hline $\begin{array}{l}\text { Technological change } \\
\text { With constraint }^{\mathrm{d}} \\
\text { Without constraint }^{\mathrm{d}}\end{array}$ & $\begin{array}{l}0.85 \\
6.51\end{array}$ & $\begin{array}{l}65.31 \\
62.86^{f}\end{array}$ & $\begin{array}{l}65.82 \\
63.93\end{array}$ \\
\hline Combination ${ }^{\mathrm{d}}$ & 6.51 & 84.91 & 86.36 \\
\hline
\end{tabular}

a $\mathrm{CO}_{2}$ reduction target: $20 \%$ of year 2000 baseline emissions and with $100 \%$ compliance; translates into $65.31 \%$ of year 2025 emissions.

b $\mathrm{NA}=$ not applicable.

c Constraint that sets limits on changes in sectoral output levels.

d Constraint that requires $\mathrm{CO}_{2}$ emissions be reduced by $65.31 \%$ of year 2025 baseline.

e Loosens constraint on sectoral output levels.

f Represents maximum achievable reduction. 


\subsection{INVESTMENT ANALYSIS}

Section 4 shows that this model lacks a sophisticated investment equation. This limitation is potentially important and could significantly reduce the accuracy of the results. However, this limitation is not a major factor. It is estimated that investment requirements for the $\mathrm{CO}_{2}$ mitigation strategies simulated in this section are very small.

Moreover, several studies foresee, and many policymakers pronounce, that industrialized countries will assist China in mitigating $\mathrm{CO}_{2}$. Examples include redistribution of international carbon tax revenues, revenues from selling marketable permits, or technology transfers associated with joint implementation.

The computations used in the investment analysis are provided on separate spreadsheets found in Appendix B. This investment analysis uses three major constructs. First is a capital cost factor for electricity generation and transmission for power plants of various types (Table B.1 in Appendix B), as well as an investment factor for exploring and producing the associated fuels (Table B.2 in Appendix B). Second are baseline projections of electricity demand (Tables 14 and 15). Third are projections of electricity demand associated with two major strategies (Tables $47,48,53$, and 54). Only an investment analysis is conducted for the upper-bound cases, as defined in Sections 4-6. However, these cases are likely to be upper-bound cases in terms of investment requirements.

This investment cost analysis begins with multiplying the cost factors by two types of electricity demand projections - baseline and mitigation strategy. The investment ascribed to a given strategy is the difference between these projections, i.e., the incremental investment. $^{20}$ One of the reasons that the investment estimates are so low is that China's economy is projected to undergo continual high growth over the forecast period. This growth signals the need for significant investment in electricity generation, even in the absence of any efforts to curb $\mathrm{CO}_{2}$ emissions. Some key summary data are presented in Table 58 and in Appendix B.

The results for Strategy 3 (interfuel substitution) are presented in Table 58. The switch toward natural gas and nuclear power requires more investment for power plants that use these fuels and a reduction in investment for the other three kinds of power plants in each of the three simulation periods, though to varying degrees. Negative investment implies that, as the amount of a particular fuel used decreases, less money is needed for replacing and expanding investment than is needed in the baseline case. The same is true for the fuel cost, though to varying degrees. Thus, large investments per unit of capacity for nuclear power plants also go hand in hand with relatively small increases in investment on the fuel side. These two aspects for all fuels taken together lead to an estimate of negative gross investment associated with Strategy 3 for all three time periods.

20 The baseline electricity projections use fixed fuel proportions, fixed electricity-generating technology, and fixed combustion efficiency between 2000 and 2025. 
TABLE 58 Gross Investment for $\mathrm{CO}_{2}$ Mitigation: Interfuel Substitution and Technological Change Strategies (billions of 1990 dollars)

\begin{tabular}{lccc}
\hline & Per Year & Per Year & Per Year \\
Strategy/Investment & $1990-2000$ & $2000-2010$ & $2010-2025$ \\
\hline Interfuel Substitution & & & \\
$\quad$ Generation transmission & $-8.3^{\mathrm{a}}$ & -7.4 & 38.8 \\
Exploration production & 5.4 & 0.1 & -72.2 \\
Total & -2.9 & -7.3 & -33.4 \\
& & & \\
Technological Change & & & \\
Generation transmission & -6.1 & -19.5 & 22.0 \\
Exploration production & 08.1 & -27.7 & -75.2 \\
Total & -14.2 & -8.2 & -53.2 \\
\hline
\end{tabular}

a Negative numbers indicate savings with respect to baseline case (see text).

For Strategy 4 (technological change), investment reflects the cost of added electricity capacity to support the displacement of coal (Table 22). However, strongly offsetting this investment are conservation and improvements in combustion efficiency. Although the investment requirements in power generation/transmission are positive for the last two time periods (2000-2010 and 2010-2025), the fuel cost savings are substantially greater, especially for oil. ${ }^{21}$

Even without fuel cost savings, if plant construction estimates are analyzed, a maximum of $\$ 38.8$ billion is needed during any given year. This figure amounts to less than $2 \%$ of the GDP in 2010 and $1.5 \%$ of the GDP in $2025 .^{22}$

The investment burden is also eased because China is a growing economy. The strategy presented in this report calls for a slow phase-in of nuclear power before 2010 and a moderate phase-in of natural gas between 1990 and 2000. In most cases, power plants do not have to be scrapped or retrofitted; rather, the "substitution" comes through expansion investment in electricity capacity that would have been required anyway. Overall, the investment burden for mitigating $\mathrm{CO}_{2}$ is less costly in growing economies.

Also, China is likely to receive assistance in meeting $\mathrm{CO}_{2}$ mitigation commitments associated with an international agreement on global warming. Currently, policymakers are exploring opportunities for joint implementation, with its emphasis on technology transfer

21 This fact overlooks some of the other benefits of using less oil, such as managing foreign exchange.

${ }^{22}$ Cost savings associated with relieving China of constructing industrial boilers and other sectorspecific coal-burning equipment displaced by electricity have been omitted in the technological change strategy. 
from industrialized to developing countries. Joint implementation generalizes to an international market in $\mathrm{CO}_{2}$ permits, or entitlements. Estimates by Barrett et al. (1992), Rose and Stevens (1993), and others range in the billions, if not tens of billions, of dollars per year for revenues that China is likely to receive for selling some of its permit stock. Similar size transfers are envisioned if carbon tax revenues are redistributed (Manne and Richels 1992).

However, there is still a potentially important opportunity cost associated with some of the strategies simulated - the fact that China's vast coal resources will not be used (unless some inexpensive way is found to scrub the $\mathrm{CO}_{2}$ out of coal gases). On the lowerbound side, some penalty might be calculated for the cost differential between coal and other fuels (although this penalty is likely to be very small when capital and fuel costs are combined). On the upper-bound side, a loss in the asset value of coal not burned might be considered. This analysis indicates that the former estimate would be close to zero, while the latter might appear to be large. Still, the asset value should be analyzed in terms of discounted present values of differential losses between burning coal now and some time in the future.

Finally, an investment burden of $1 \%$ of the GDP is still meaningful if it displaces investment in ordinary plants and equipment and if the ensuing general equilibrium effects are dampening. Even here, the economic impacts are not likely to translate more than proportionately. That is, investment requirements to mitigate $\mathrm{CO}_{2}$ that are $1 \%$ of the GDP are likely to reduce the GDP by at most $1 \%$. Given all of the other factors noted above, the impact will probably be much less.

\subsection{SUMMARY OF THE RESULTS}

The results of six sets of simulations are presented in Tables 49-53. These results include upper-bound simulations for 2000, 2010, and 2025, as well as lower-bound simulations for the same target years. The major findings are discussed in the following:

- To meet the $5 \%$ target $\mathrm{CO}_{2}$ reduction for the year 2000, China has several options that do not adversely affect its development plans. In fact, strategies that involve conservation and displacement of coal in industrial uses may actually boost economic growth very slightly above baseline projections. Moreover, it appears that actions taken to mitigate $\mathrm{CO}_{2}$ emissions also reduce emissions of other major air pollutants, such as $\mathrm{SO}_{\mathrm{x}}$, by approximately as much.

- By 2010, the effective abatement requirement becomes $57.30 \%$ and $40.50 \%$ for the upper- and lower-bound cases, respectively, of that year's emissions. This stiffening of the requirement renders most single strategies infeasible, i.e., incapable of achieving the desired emission reduction target on their own. A combination of strategies can attain 
the target with only a slight decrease in the baseline GNP growth rate in the lower-bound case and no decrease in the upper-bound one.

- By 2025, fewer options are open for achieving the target of $84.91 \%$ and $65.31 \%$ of that year's baseline $\mathrm{CO}_{2}$ emissions. A change in sectoral mix cannot achieve the results, and autonomous conservation can only achieve reductions of about one-half of the upper-bound target and twothirds of the lower-bound one, and only at a very great penalty in both cases. However, interfuel substitution and technological change could be combined to attain the targeted reduction of $\mathrm{CO}_{2}$ emissions in the upper-bound case, and with little economic penalty. Still, the result highly depends on the assumption of total displacement of coal in industry and very substantial shifts to nuclear, hydro, and gas-fired electric power generation. Otherwise, China's economy could suffer reductions of economic growth 1.0-3.0\% below baseline. For the lowerbound case, a mix of interfuel substitution, technological change, and sectoral mix changes can achieve the target, but at a sizable penalty that would reduce economic growth from 3 to $0.85 \%$.

- For 2000 and 2010 , the results presented in this report do not differ significantly between upper- and lower-bound cases, suggesting they are robust over a broad range of assumptions relating to China's economy, its energy reserves, and energy technologies for those years.

- Unless the $\mathrm{CO}_{2}$ reduction measures enacted in China are sustainable (i.e., work their way into the very fabric of the Chinese economy and energy system), it could become costly to achieve the reduction requirements in 2025 and beyond under either the upper-or lowerbound scenario. Doing so may have to involve restructuring the economy and implementing conservation measures that are no longer costless. In fact, unless major resource discoveries or technological innovations occur, over and above those projected in this report, $\mathrm{CO}_{2}$ reduction targets beyond 2025 may not even be feasible. This possibility may even be the case for 2025 if some of the lower-bound assumptions have been too optimistic. 


\section{BIBLIOGRAPHY}

Agarwal, A., and S. Narain, 1991, Global Warming in an Unequal World: A Case of Environmental Colonialism, Centre for Science and Environment, New Delhi, India.

Albouy, Y., 1991, Coal Pricing in China: Issues and Reform Strategy, The World Bank, Washington, D.C.

Allen, F.H., and R.D. Seba, 1993, Economics of Worldwide Petroleum Production, Oil \& Gas Consultants International, Inc., Tulsa, Okla.

Almon, C., 1963, "Consistent Forecasting in a Dynamic Multi-Sector Model," Review of Economics and Statistics 65:148-161.

ANL, 1994, "Analysis of Coal Fuel Cycle in China," prepared for Argonne National Laboratory, Argonne, Ill., by SFA Pacific, Inc., Mountain View, Calif.

Asian Development Bank, 1994, National Response Strategy for Global Climate Change: People's Republic of China, TA 1690-PRC, Technical Assistance Project, Manila, Philippines.

Ayres, R., and U. Simonis (eds.), 1994, Industrial Metabolism: Restructuring for Sustainable Development, United Nations University Press, Tokyo, Japan.

Barrett, S., et al., 1992, Combating Global Warming: A Global System of Tradeable Carbon Emission Entitlements, United Nations Conference on Trade and Development, Geneva, Switzerland.

Bhatti, N., et al., 1994, Coal Use in the People's Republic of China, Volume 1: Environmental Impacts, ANL/DIS/TM-18, Argonne National Laboratory, Argonne, IIl., Nov.

British Petroleum, 1993, BP Statistical Review of World Energy, Employee Communications and Services, London, United Kingdom.

Bruno, M., et al., 1970, "Dynamic Input-Output, Trade and Development," in A. Carter and A. Brody (eds.), Applications of Input-Output Analysis, North-Holland, Amsterdam, the Netherlands.

Chandler, W. (ed.), 1990, Carbon Emissions Control Strategies, World Wildlife Fund and the Conservation Foundation, Washington, D.C.

Chenery, H., and P. Clark, 1959, Interindustry Economics, Wiley, New York, N.Y.

Cheng, C., 1984, The Demand and Supply of Primary Energy in Mainland China, Chung-Hua Institution for Economic Research, Taipei, Taiwan.

China Coal Industry Yearbook, 1986, Ministry of Coal Industry, Beijing, People's Republic of China, Economic Information and Agency Press, Hong Kong. 
China Statistical Yearbook, 1988, State Statistical Bureau of China, China Statistical Press, Beijing, People's Republic of China.

China Statistical Yearbook, 1991, 1992, State Statistical Bureau of China, Beijing, People's Republic of China, Hong Kong Center for the Advancement of Science and Technology, Ltd.

China Statistical Yearbook, 1992, State Statistical Bureau of China, China Statistical Publishing House, Beijing, People's Republic of China.

"China: Treating the New Frontier with Caution," 1994, Petroleum Economist 61:8-12, June.

"Chinese Number Games," 1993, Energy Economist 140:11-13.

"Chinese Number Games," 1994, Energy Economist 140:10-14.

Cline, W., 1992, The Economics of Global Warming, Institute for International Economics, Washington, D.C.

"Coal in China," 1994, Mining Journal 80, July 8.

Dervis, K. J. de Melo, and S. Robinson, 1982, General Equilibrium Models for Development Policy, Cambridge University Press, Cambridge, Mass.

Dorian, J.P., and D.G. Fridley, 1985, China's Energy and Mineral Industries: Current Perspectives, Westview Press, Boulder, Colo.

Dowlatabad, H., and M.A. Toman, 1991, Technology Options for Electricity Generation, Johns Hopkins University Press, Baltimore, Md.

"Electricity in China: Power Surge," 1994, The Economist 330(7855):81-82.

Gibbons, R.J., 1993, "Power Funding," The China Business Review 20(6):28-32.

Goldstein, C., 1992, "China's Generation Gap," Far Eastern Economic Review 155(23):45-47.

Goldstein, C., 1992, "The Nuclear Option: China's Programme Dogged by Delays," Far Eastern Economic Review 155(23):50-51.

Grubb, M., and J. Sebenius, 1991, "Participation, Allocation, and Adaptability in International Tradeable Emission Permit Systems for Greenhouse Gas Control," Paper prepared for Organization for Economic Cooperation and Development Workshop on Tradeable Greenhouse Gas Permits, Paris, France.

Hamburger, J., 1993, "Lighting the Way for Energy Savings," The China Business Review 20(6):42-44.

Huang, J.P., 1993, "Electricity Consumption and Economic Growth. A Case Study of China," Energy Policy 21(6):717-720. 
Input-Output Table of China 1987, 1990, Department of Balances of National Economy of the State Statistical Bureau and Office of the National Input-Output Survey, China Statistical Publishing House, Beijing, People's Republic of China.

Intergovernmental Panel on Climate Change, 1992, Climate Change: The IPCC Scientific Assessment (revised), Cambridge University Press, New York, N.Y.

International Energy Agency, 1988, Mineral Industry in China, United Nations, New York, N.Y.

International Energy Agency, 1990, Mineral Industry in China, United Nations, New York, N.Y.

International Energy Agency, 1992, Climate Change Policy Initiatives, prepared by the Organization for Economic Cooperation and Development, Paris, France.

Khazzoom, D., 1980, "Economic Implications of Mandated Efficiency Standards for Household Appliances," Energy Journal 1:21-39.

Kim, Y.C., 1993, "Multicriteria Generation - Expansion Planning with Global Environmental Considerations," IEEE Transactions on Engineering Management 40:158-163.

"Late Welcome for Foreign Funds," 1994, Petroleum Economist 61:8-12, June.

Leontief, W., 1986, Input-Output Economics (2nd Ed.), Oxford University Press, Oxford, United Kingdom.

Lin, X, and K.R. Polenske, 1993, "Input-Output Anatomy of China's Energy-Demand Change, 1981-1987," Multiregional Planning Research, Massachusetts Institute of Technology, Cambridge, Mass.

Lindzen, R., 1992, Global Warming: The Origin and Nature of the Alleged Scientific Consensus Regulation, Vol. 13, pp. 87-98.

Manne, A., and R. Richels, 1991, "Global $\mathrm{CO}_{2}$ Emission Reductions: The Impacts of Rising Energy Costs," Energy Journal 12:87-107.

Miller, R.E., and P.D. Blair, 1985, Input-Output Analysis: Foundations and Extensions, Prentice-Hall, Englewood Cliffs, N.J.

Ministry of Energy, 1993, Energy in China 1992, Beijing, People's Republic of China.

National Academy of Sciences, 1991, Policy Implications of Greenhouse Warming, National Academy Press, Washington, D.C.

Nordhaus, W, 1993, "Rolling the DICE: The Optimal Transition Path for Controlling Greenhouse Gases," Resource and Energy Economics 15:27-50. 
Office of Technology Assessment, 1991, Changing by Degrees: Steps to Reduce Greenhouse Gases, Washington, D.C.

Pezzey, J., 1992, "The Symmetry between Controlling Pollution by Price and by Quantity," Canadian Journal of Economics 25:983-91.

Polenske, K.R., and X. Chen, 1991, Chinese Economic Planning and Input-Output Analysis, Oxford University Press, New York, N.Y.

Rose, A., and W. Miernyk, 1989, "Input-Output Analysis: The First Fifty Years," Economic Systems Research 1:229-271.

Rose, A., and S. Lin, 1994, "Regrets or No Regrets - That Is the Question: Economic Impacts of a Conservation Strategy for $\mathrm{CO}_{2}$ Mitigation," Paper presented at the International Meeting of the International Association for Energy Economics, Stavanger, Norway, May.

Rose, A., and B. Stevens, 1993, "The Efficiency and Equity of Marketable Permits for $\mathrm{CO}_{2}$ Emissions," Resource and Energy Economics 15:117-46.

Rose, A., B. Stevens, and P. Li, 1994, "A Global Marketable Permits Approach to $\mathrm{CO}_{2}$ Mitigation: Implications of U.S. Energy Demand," in E.C. van Ierland (ed.) International Environmental Economics, North-Holland, Amsterdam, the Netherlands

Schneider, D., et al., 1993, "Power Plays," The China Business Review 20(6):20-27.

Smil, V., 1988, Energy in China's Modernization, Advances and Limitations, M.E. Sharpe, Inc., Armonk, N.Y.

State Statistical Bureau, 1988, China Statistical Yearbook, 1988, International Centre for the Advancement of Science and Technology, Ltd., Beijing, People's Republic of China.

Statistical Office of the European Community (EUROSTAT), 1991, Energy Monthly Statistics 10:35.

Tang, C., and S.J. La Croix, 1993, "Energy Consumption and Economic Activity in China," The Energy Journal 14:21-36.

Task Force on the Comprehensive Approach to Climate Change, 1991, A Comprehensive Approach to Addressing Potential Climate Change, U.S. Department of Justice, Environment and Natural Resources Division, Washington, D.C.

Taylor, L., 1979, Macro Model for Developing Countries, McGraw-Hill Book Company, Inc., New York, N.Y. 
APPENDIX A1:

UPPER-BOUND SIMULATIONS 


\begin{tabular}{|c|c|c|c|c|c|c|c|c|c|c|c|c|c|c|c|c|}
\hline & \multicolumn{3}{|c|}{$\begin{array}{l}\text { BASE } \\
1990 \\
\end{array}$} & \multicolumn{3}{|c|}{$\begin{array}{r}\text { DLP } \\
1990 \\
\end{array}$} & \multicolumn{3}{|c|}{$\begin{array}{r}\text { DLP } \\
2000 \\
\end{array}$} & \multicolumn{3}{|c|}{$\begin{array}{r}\text { DLP } \\
2010 \\
\end{array}$} & \multicolumn{3}{|c|}{$\begin{array}{r}\text { DLP } \\
2025 \\
\end{array}$} & \multirow{2}{*}{$\begin{array}{c}\text { CO2 } \\
\text { COEFFICIEN } \\
\text { (IOn/ho Yuan) }\end{array}$} \\
\hline & $\begin{array}{c}\text { Final } \\
\text { Demand }\end{array}$ & $\begin{array}{l}\text { Gross } \\
\text { Output }\end{array}$ & $\begin{array}{c}\mathrm{CO2} \\
\text { (m) ton) }\end{array}$ & $\begin{array}{c}\text { Final } \\
\text { Demand }\end{array}$ & $\begin{array}{l}\text { Gross } \\
\text { Output }\end{array}$ & $\begin{array}{c}\mathrm{CO} \\
\text { (mul ton) }\end{array}$ & $\begin{array}{c}\text { Final } \\
\text { Demand }\end{array}$ & $\begin{array}{l}\text { Gross } \\
\text { Outpui }\end{array}$ & $\underset{\text { (mit tan) }}{\mathrm{CO} 2}$ & $\begin{array}{c}\text { Final } \\
\text { Demand }\end{array}$ & $\begin{array}{l}\text { Gross } \\
\text { Output }\end{array}$ & $\begin{array}{c}\mathrm{CO2} \\
\text { (mil ton) }\end{array}$ & $\begin{array}{c}\text { Final } \\
\text { Demana }\end{array}$ & $\begin{array}{l}\text { Gross } \\
\text { Oulput }\end{array}$ & $\begin{array}{c}\mathrm{CO} 2 \\
\text { (mition) }\end{array}$ & \\
\hline 1 Agnculture & 409 & 772 & 43 & 491 & 879 & 49 & 1,387 & 2.171 & 121 & 2.860 & 4,475 & 249 & 7.354 & 11.509 & 648 & 00557 \\
\hline 3 Crude petroleum 8 natural gas prod & $?$ & 44 & $\mathbf{9}$ & 9 & 46 & 10 & 25 & 109 & 23 & 52 & 224 & 48 & 134 & 577 & 124 & 02141 \\
\hline 4 Metal ole mining & (1) & 15 & 0 & 0 & 14 & 0 & 0 & 28 & o & 0 & 57 & $\mathbf{0}$ & 0 & 146 & 0 & 00000 \\
\hline 5 Other mining & 0 & 35 & 0 & 0 & 31 & 0 & 0 & 67 & 0 & 1 & 138 & 0 & 2 & 355 & 0 & 00000 \\
\hline 6 Food manufacturing & 204 & 305 & 62 & 245 & 353 & 72 & 346 & 561 & 115 & 713 & 1,157 & 237 & 1,033 & 2,915 & 608 & 02045 \\
\hline 7 Manulaclure of textiles & 99 & 275 & 44 & 79 & 237 & 38 & 168 & 502 & 81 & 346 & 1.035 & 167 & 890 & 2.663 & 430 & 0.1615 \\
\hline 8 Manufacture of apparel & 58 & 77 & 0 & 46 & 63 & 0 & 98 & 135 & 0 & 203 & 278 & 0 & 522 & 714 & 0 & 0.0000 \\
\hline 10 Manufacture of paper and educ material & 25 & 110 & 31 & 30 & 116 & 32 & 42 & 233 & 65 & 87 & 480 & 134 & 223 & 1,235 & 346 & 02799 \\
\hline 1 Electricity, ste3m and hot water prod & 0 & 65 & 509 & 7 & 64 & 499 & 19 & 142 & 1,105 & 39 & 292 & 2.278 & 101 & 750 & 5,859 & 7.8119 \\
\hline 12 Petroleum refinenies & 2 & 60 & 39 & 2 & 61 & 40 & 8 & 141 & 92 & 14 & 290 & 189 & 37 & 745 & 486 & 0.6523 \\
\hline 3 Coking, manufacture of gas \& coal & 3 & 10 & 84 & 2 & 9 & $\pi$ & 5 & 18 & 154 & 10 & 38 & 317 & 25 & 97 & 816 & 8.4178 \\
\hline 4 Chemical industries & 21 & 300 & 166 & 25 & 287 & 159 & 36 & 616 & 342 & 74 & 1,270 & 704 & 190 & 3,266 & 1.810 & 0.5543 \\
\hline 5 Manufacture of building materials & 2 & 132 & 188 & 2 & 117 & 166 & 6 & 250 & 355 & 12 & 516 & 733 & 31 & 1,327 & 8.884 & 1.4199 \\
\hline 6 Primary metal manulacturing & (22) & 179 & 153 & 0 & 161 & 137 & 0 & 311 & 266 & 0 & 641 & 547 & 0 & 1.648 & 1.408 & 0.8542 \\
\hline 7 Manufacture ol metal products & 19 & 80 & 16 & 23 & 78 & 15 & 32 & 148 & 29 & 66 & 305 & 59 & 169 & 784 & 152 & 0.1941 \\
\hline 8 Manulacture of machinery & 103 & 231 & 28 & 123 & 203 & 25 & 174 & 331 & 40 & 359 & 683 & 83 & 924 & 1.757 & 214 & 0.1218 \\
\hline 9 Manulaclure of transport equipment & 27 & 66 & 8 & 32 & 54 & 7 & 46 & 92 & 11 & 94 & 190 & 23 & 242 & 489 & 60 & 0.1218 \\
\hline 0 Manulacture of electric machinery & 40 & 98 & 12 & 48 & 94 & 11 & 69 & 159 & 19 & 141 & 327 & 40 & 363 & 841 & 102 & 0.1218 \\
\hline 1 Manulacture of electronics equip & 31 & 64 & $\mathbf{8}$ & 37 & 59 & 7 & 78 & 125 & 15 & 161 & 257 & 31 & 414 & 662 & 81 & 0.1218 \\
\hline 2 Manulacture of instruments & (1) & 13 & 0 & 0 & 7 & 0 & 0 & 14 & 0 & 0 & 30 & 0 & 0 & 76 & 0 & 0.0000 \\
\hline 5 Construction & 402 & 402 & 10 & 321 & 321 & 8 & 681 & 681 & 17 & 1.403 & 1.403 & 35 & 3.609 & 3,609 & 90 & 0.0250 \\
\hline 6 Freight transpont and communication & 41 & 113 & 47 & 49 & 122 & 51 & 138 & 292 & 122 & 285 & 602 & 251 & 732 & 1.549 & 644 & 0.4161 \\
\hline 7 Commerce & 28 & 170 & 16 & 34 & 155 & 14 & 96. & 347 & 32 & 198 & 715 & 66 & 510 & 1,838 & 169 & 0.0921 \\
\hline Restaurants & 46 & 47 & 4 & 44 & 44 & 4 & 79 & 79 & 7 & 163 & 163 & 15 & 418 & 418 & 39 & 0.0921 \\
\hline Passenger llanspont & 14 & 25 & 3 & 16 & 29 & 3 & 46 & 78 & $\boldsymbol{9}$ & 95 & 160 & 18 & 245 & 412 & 47 & 0.1135 \\
\hline 0 Public uiltutes and services to house & 72 & 95 & 8 & 86 & 110 & 10 & 244 & 305 & 26 & 504 & 628 & 54 & 1,296 & 1.614 & 140 & 0.0864 \\
\hline 1 Cullural, education and healtn services & 153 & 193 & 17 & 183 & 226 & 20 & 518 & 620 & 54 & 1.068 & 1,278 & 110 & 2,746 & 3.286 & 284 & 0.0864 \\
\hline 2 Finance and insurance & 2 & 79 & 7 & 2 & 75 & 6 & 6 & 161 & 14 & 12 & 331 & 29 & 30 & 851 & 74 & 00864 \\
\hline 3 Public administration & 63 & 63 & 5 & 75 & 75 & 6 & 212 & 212 & 18 & 437 & 437 & 38 & 1,125 & 1.125 & 97 & 0.0864 \\
\hline
\end{tabular}




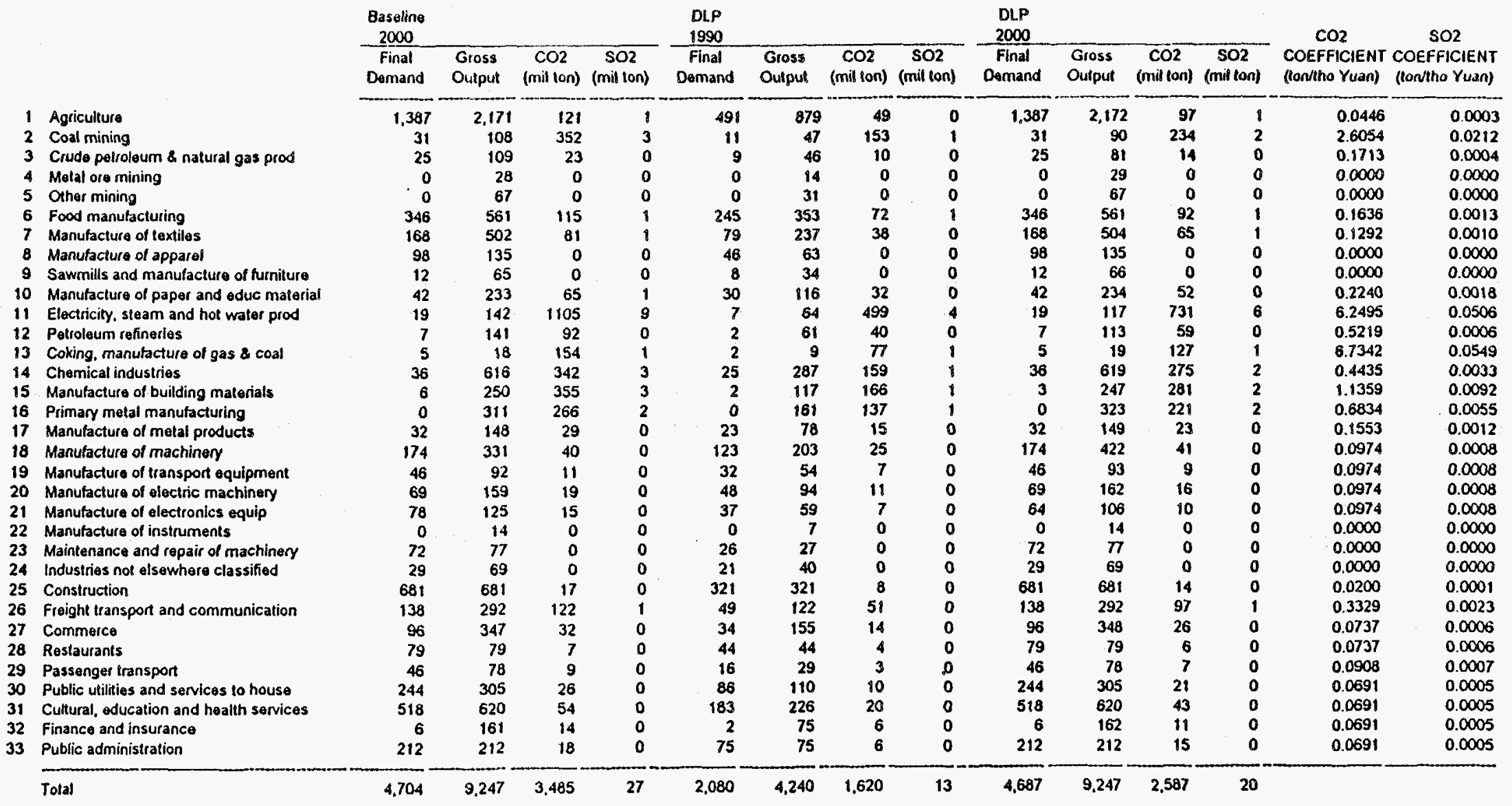

Final Demand and Gross Output in billiens of 1990 Yuans

Final Demand(GDP) Growh Rate

$1990-2000 \quad 8.46 \%$
$\mathrm{CO} 2$ Emission Reduction

1990.2000 25.78\% 
1 Agriculture

3 Crude pettoleum \& natural gas prod

4 Motal ore mining

6 Food manufacturing

7 Man manulacluring

Ganulacturo of appilas

Manmils and apparal

10 Manulacture of paper and oduc material

II Eloctricity, steam and hot water prod

12 Potroleum refinerios

12 Potroleum refineries

Coking. manulactur

15 Manufacture of building materials

16 Primary metal manufacturing

18 Manufacture of metal products

19 Manufacture of transport equipment

Manufacture of electric machinery

Manulacture of electric machinery

21 Manufacture of olectronics equip

23 Maintenance and repair of machinery

24 Industries not elsewhere classified

25 Construction

26 Fieight transport and communication

27 Commerce

28 Restaurants

Passenger transport

Public utilities and services to house

31 Cultural, education and hoalth services

Finance and insurance

33 Public administration

Total

final Gross $\mathrm{CO}_{2} \mathrm{SO2}-19$

OLP

DLP

$\frac{2000}{\text { Final }}$

Gross

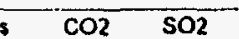

Gross $\mathrm{CO} \quad \mathrm{SO} 2$

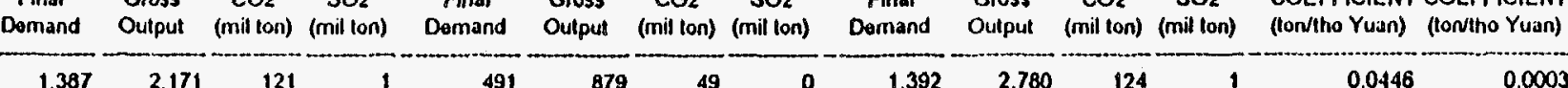

$\begin{array}{lc}\text { CO2 } & \text { SO2 } \\ \text { COEFFICIENT COEFFICIEN }\end{array}$

1.387

2.17
0
0

108 352

0067

$346 \quad 56$

98

12

42

19

7
5

5
36
6

6 250

$\begin{array}{rr}0 & 311 \\ 32 & 148\end{array}$

$\begin{array}{rr}174 & 148\end{array}$

$\begin{array}{rrr}46 & 92 & 11 \\ 69 & 159 & 19\end{array}$

$\begin{array}{lll}69 & 159 & 19 \\ 78 & 125 & 15\end{array}$

$\begin{array}{llll}0 & 14 & 15 & 0\end{array}$

$\begin{array}{llll}72 & 77 & 0 & 0\end{array}$

$\begin{array}{rrr}29 & 69 & 0 \\ 681 & 681 & 17\end{array}$

$\begin{array}{lll}138 & 292 & 122\end{array}$

$\begin{array}{llll}96 & 347 & 32 & 0\end{array}$

$\begin{array}{llll}76 & 78 & 9 & 0\end{array}$

$\begin{array}{rrrr}46 & 78 & 9 & 0 \\ 244 & 305 & 26 & 0\end{array}$

$\begin{array}{llll}244 & 305 & 26 & 0 \\ 518 & 620 & 54 & 0\end{array}$

$\begin{array}{rrrr}6 & 161 & 14 & 0 \\ 212 & 212 & 18 & 0\end{array}$

4.704

$27 \quad 2.080$

$\begin{array}{r}879 \\ 47 \\ 46 \\ 14 \\ 31 \\ 353 \\ 237 \\ 63 \\ 34 \\ 116 \\ 64 \\ 61 \\ 9 \\ 287 \\ 117 \\ 161 \\ 78 \\ 203 \\ 54 \\ 94 \\ 59 \\ 7 \\ 27 \\ 40 \\ 321 \\ 122 \\ 155 \\ 44 \\ 29 \\ 110 \\ 226 \\ 75 \\ 75 \\ \hline 29 \\ \hline 24\end{array}$

10

0

72

0

$4,240 \quad 1,620$

13

$4,701 \quad 11,836 \quad 3,311$

26

Final Demand and Gross Output in billions of 1990 Yuans

Final Domand(GDP) Growh Rate

$\mathrm{CO} 2$ Emission Reduction

1990-2000 $8.49 \%$

1990-2000 
1 Agriculture

3 Crude petroleum \& natural gas prod

4 Motal ore mining

5 Other mining

Food manufacturing

Manulacture of textiles

Manufaclure of apparel

Sawmils and manufacture of furniture

10 Manufacture of paper and educ material

11 Electricity, steam and hot water prod

12 Petroleum refineries

13 Coking. manufacture of gas \& coal

14 Chemical industries

15 Manufacture of building materials

16 Primary metal manufacturing

17 Manulacture of motal products

18 Manulacture of machinery

19 Manufacture of transport equipment

20 Manufacture of electric machinory

21 Manufacture of oloctronics oquip

22 Manufacture of instruments

24 Maintenance and repair of machinery

24 Industries nol

26 Freight transport and communication

27 Commerce

28 Restaurants

30 Public utilities and services to house

31 Cultural, oducation and health services

32 Finance and insurance

33 Public administration

Total

\begin{tabular}{|c|c|c|c|c|c|c|c|}
\hline Easeline & & & & DLP & & & \\
\hline 2010 & Gross & $\mathrm{CO} 2$ & $\mathrm{SO} 2$ & 2000 & Gross & $C O ?$ & \\
\hline $\begin{array}{c}\text { Hinal } \\
\text { Demand }\end{array}$ & Oulput & (miit ton) & (miil ton) & $\begin{array}{l}\text { Final } \\
\text { Domand }\end{array}$ & Oulput & (mil ton) & (milion) \\
\hline
\end{tabular}

DLP

$\mathrm{CO} 2 \mathrm{SO} 2$

\begin{tabular}{|c|c|c|c|c|c|c|c|c|c|c|c|c|c|}
\hline Lemand & Oulput & (mint (on) & (mim ton) & Domand & Oulput & $(m i n)$ & (mintons) & Domand & Oulput & (millifon) & (smillons) & (fordthe Yuan) & (lontho Yuan) \\
\hline 2.860 & 4,475 & 249 & 2 & 1,387 & 2.172 & 97 & 8 & 2.860 & $4,4 \pi$ & 180 & 1 & 0.0401 & 0.0003 \\
\hline 65 & 223 & 726 & 6 & 31 & 90 & 234 & 2 & 65 & 171 & 401 & 3 & 2.3449 & 0.0191 \\
\hline 52 & 224 & 48 & 0 & 25 & 81 & 14 & 0 & 52 & 148 & 23 & 0 & 0.1542 & 0.0003 \\
\hline 0 & 57 & 0 & 0 & 0 & 29 & 0 & 0 & 0 & 60 & 0 & 0 & 0.0000 & 0.0000 \\
\hline 1 & 138 & 0 & 0 & 0 & 67 & 0 & 0 & 1 & 137 & 0 & 0 & 0.0000 & 0.0000 \\
\hline 713 & 1.157 & 237 & 2 & 346 & 561 & 92 & $i$ & 713 & 1,157 & 170 & 1 & 0.1472 & 0.0012 \\
\hline 346 & 1.035 & 167 & i & 168 & 504 & 65 & $i$ & 346 & 1.039 & 121 & $i$ & 0.1163 & 0.0009 \\
\hline 203 & 278 & 0 & 0 & 98 & 835 & 0 & 0 & 203 & 278 & 0 & 0 & 0.0000 & 0.0000 \\
\hline 25 & 135 & 0 & 0 & 12 & 66 & 0 & 0 & 25 & 137 & 0 & 0 & 0.0000 & 0.0000 \\
\hline 87 & 480 & 134 & $i$ & 42 & 234 & 52 & 0 & 87 & 482 & 97 & 1 & 0.2016 & 0.0016 \\
\hline 39 & 292 & 2278 & 18 & 19 & 117 & $73 i$ & 8 & 39 & 221 & 1.243 & 10 & 5.6245 & 0.0456 \\
\hline 14 & 290 & 189 & 0 & 7 & $\$ 13$ & 59 & 0 & 14 & 210 & 99 & 0 & 0.4697 & 0.0005 \\
\hline 10 & 38 & 317 & 3 & 5 & 19 & 127 & $i$ & 10 & 39 & 239 & 2 & 6.0608 & 0.0494 \\
\hline 74 & 1.270 & 704 & 5 & 36 & 619 & 275 & 2 & 74 & 1,278 & 510 & 4 & 0.3991 & 0.0030 \\
\hline 12 & 516 & 733 & 6 & 3 & 247 & 281 & 2 & 6 & 510 & 522 & 4 & 1.0223 & 0.0083 \\
\hline 0 & 641 & 547 & 4 & 0 & 323 & 221 & 2 & 0 & 676 & 416 & 3 & 0.6150 & 0.0049 \\
\hline 66 & 305 & 59 & 0 & 32 & 149 & 23 & 0 & 66 & 309 & 43 & 0 & 0.1398 & 0.0011 \\
\hline 359 & 683 & 83 & 1 & 174 & 422 & 41 & 0 & 359 & 939 & 82 & 1 & 0.0877 & 0.0007 \\
\hline 94 & 190 & 23 & 0 & 46 & 93 & 9 & 0 & 94 & 191 & 17 & 0 & 0.0877 & 0.0007 \\
\hline 141 & 327 & 40 & 0 & 69 & 162 & 16 & 0 & 141 & 336 & 29 & 0 & $0.007 \pi$ & 0.0007 \\
\hline 161 & 257 & 31 & 0 & 64 & 106 & 10 & 0 & 120 & 203 & 18 & 0 & $0.08 \pi$ & 0.0007 \\
\hline 0 & 30 & 0 & 0 & 0 & 14 & 0 & 0 & 0 & 30 & 0 & 0 & 0.0000 & 0.0000 \\
\hline 149 & 159 & 0 & 0 & 72 & $\pi$ & 0 & 0 & 149 & 159 & 0 & 0 & 0.0000 & 0.0000 \\
\hline 60 & 143 & 0 & 0 & 29 & 69 & 0 & 0 & 60 & 143 & 0 & 0 & 0.0000 & 0.0000 \\
\hline 1.403 & 1.403 & 35 & 0 & 681 & 681 & 14 & 0 & 1,403 & 1,403 & 25 & 0 & 0.0180 & 0.0001 \\
\hline 285 & 602 & 251 & 2 & 138 & 292 & 97 & 1 & 285 & 601 & 180 & 1 & 0.2996 & 0.0021 \\
\hline 198 & 715 & 66 & i & 96 & 348 & 26 & 0 & 198 & 719 & 48 & 0 & 0.0663 & 0.0005 \\
\hline 163 & 163 & 15 & 0 & 79 & 79 & 6 & 0 & 163 & 163 & 11 & 0 & 0.0663 & 0.0005 \\
\hline 95 & 160 & 18 & 0 & 48 & 78 & 7 & 0 & 95 & 161 & 13 & 0 & 0.0817 & 0.0006 \\
\hline 504 & 628 & 54. & 0 & 244 & 305 & 21 & 0 & 504 & 628 & 39 & 0 & 0.0622 & 0.0005 \\
\hline 1,068 & 1,278 & 110 & 1 & 518 & 620 & 43 & 0 & 1,068 & 1,278 & 80 & 1 & 0.0622 & 0.0005 \\
\hline 12 & 331 & 29 & 0 & 6 & 162 & 11 & 0 & 12 & 336 & 21 & 0 & 0.0622 & 0.0005 \\
\hline 437 & 437 & 38 & 0 & 212 & 212 & 15 & 0 & 437 & 437 & 27 & 0 & 0.0622 & 0.0005 \\
\hline 9.695 & 19,059 & 7.183 & 56 & 4,687 & 9.247 & 2,587 & 20 & 9,648 & 19,058 & 4,652 & 36 & & \\
\hline
\end{tabular}

Final Demand and Gross Output in biltions of 1990 Yuans

Final Demand(GDP) Growth Rate 


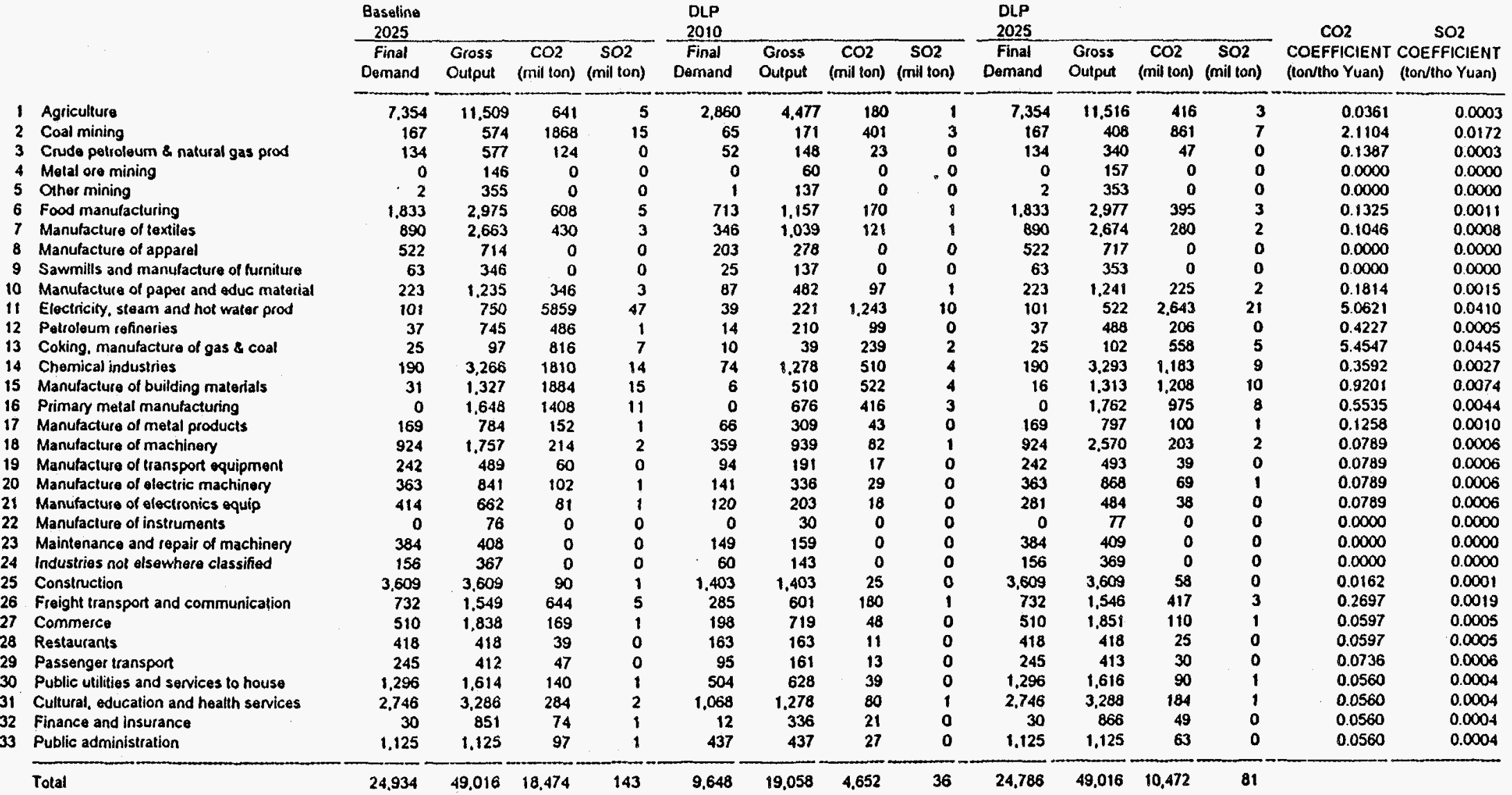




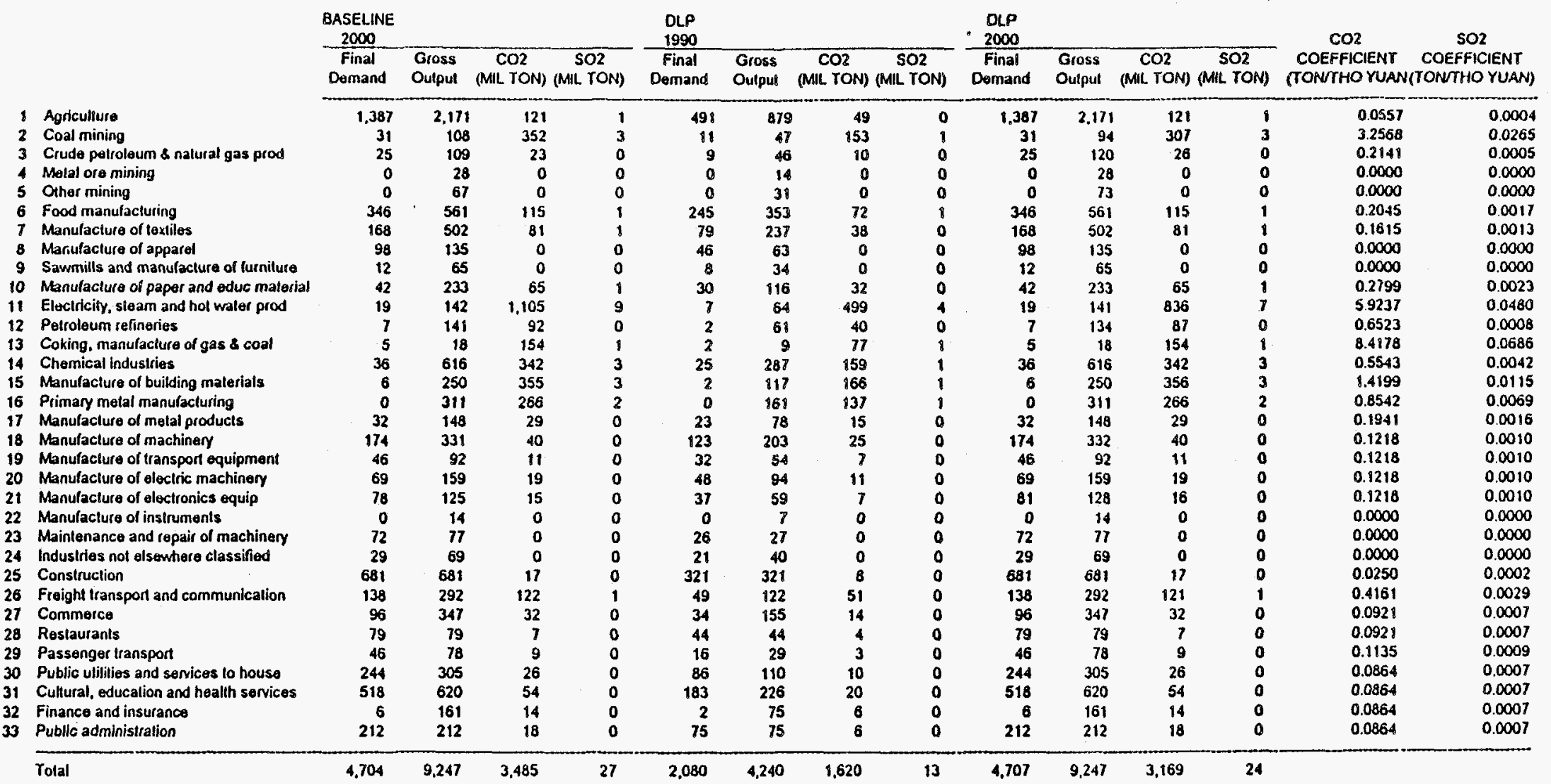




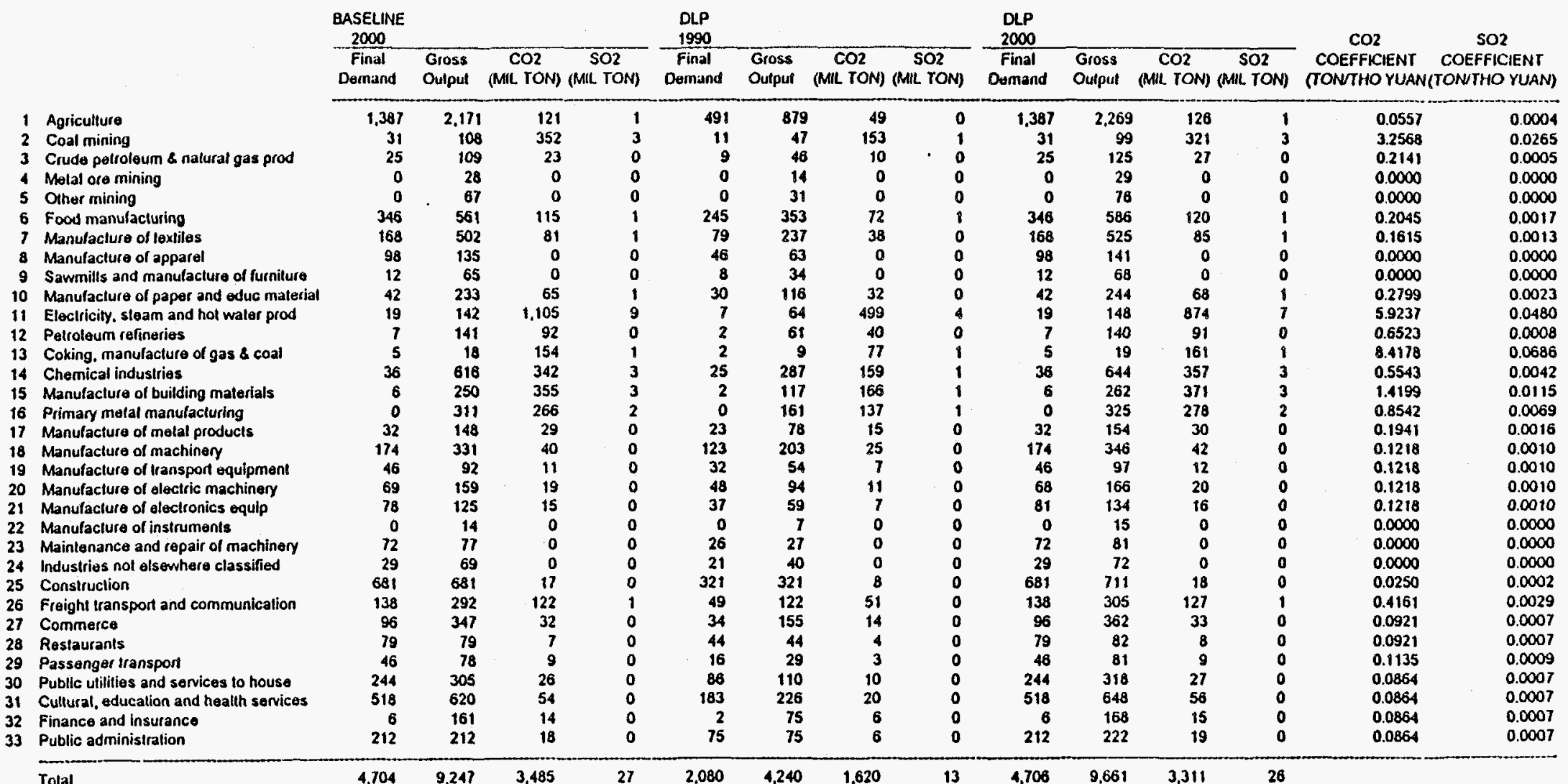

Final Demand and Gross Oulpul in billions of 1990 Yuans 




Finat Demand and Gross Output in billions of 1990 Yuans 


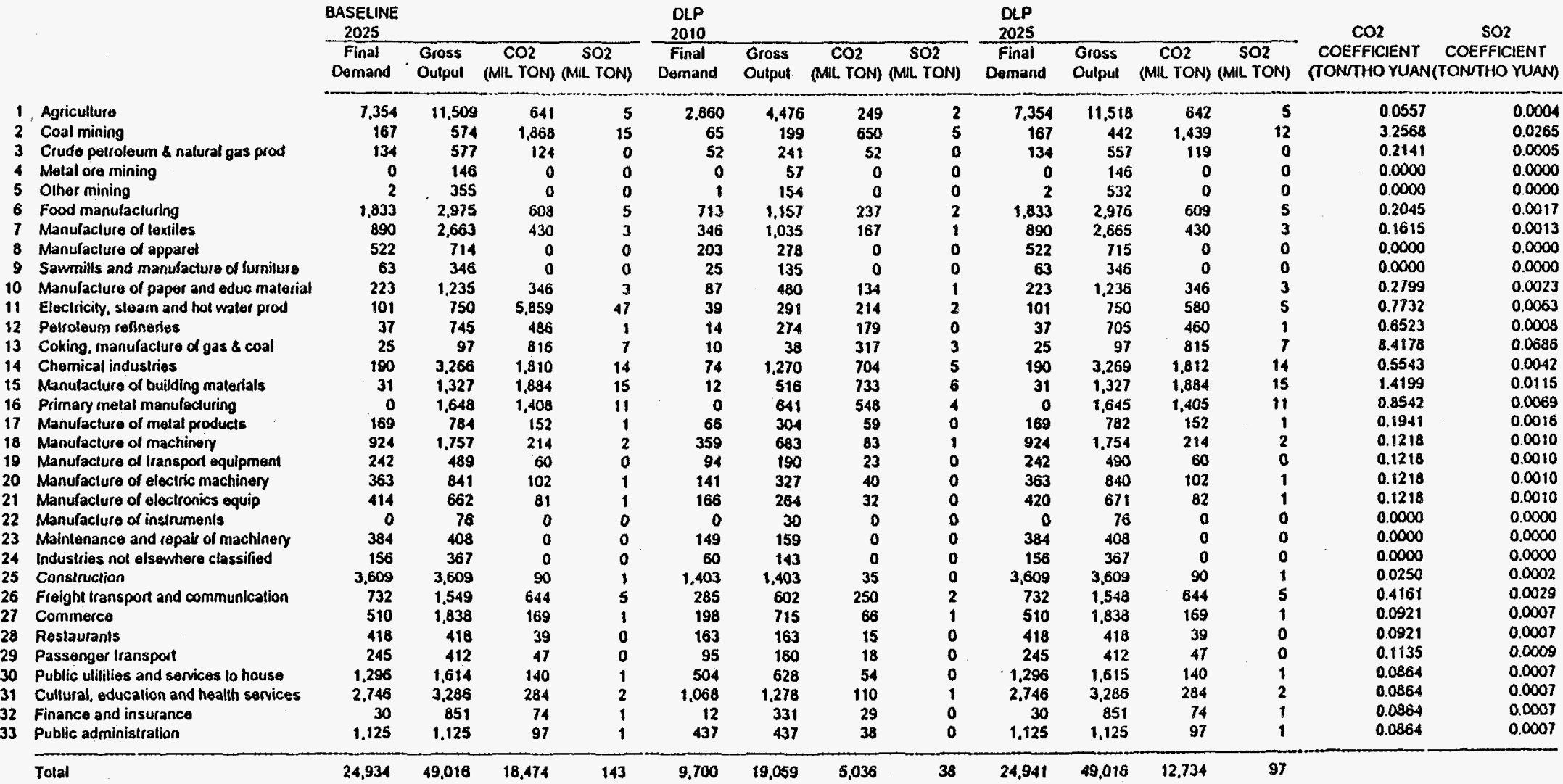

Final Dernand and Gross Output in billions of 1990 Yuans

\begin{tabular}{|c|c|}
\hline Final Demand(GDP) Gronth Rate & CO2 Emission Roduction \\
\hline $2010-2025$ & $2010-2025$ \\
\hline
\end{tabular}




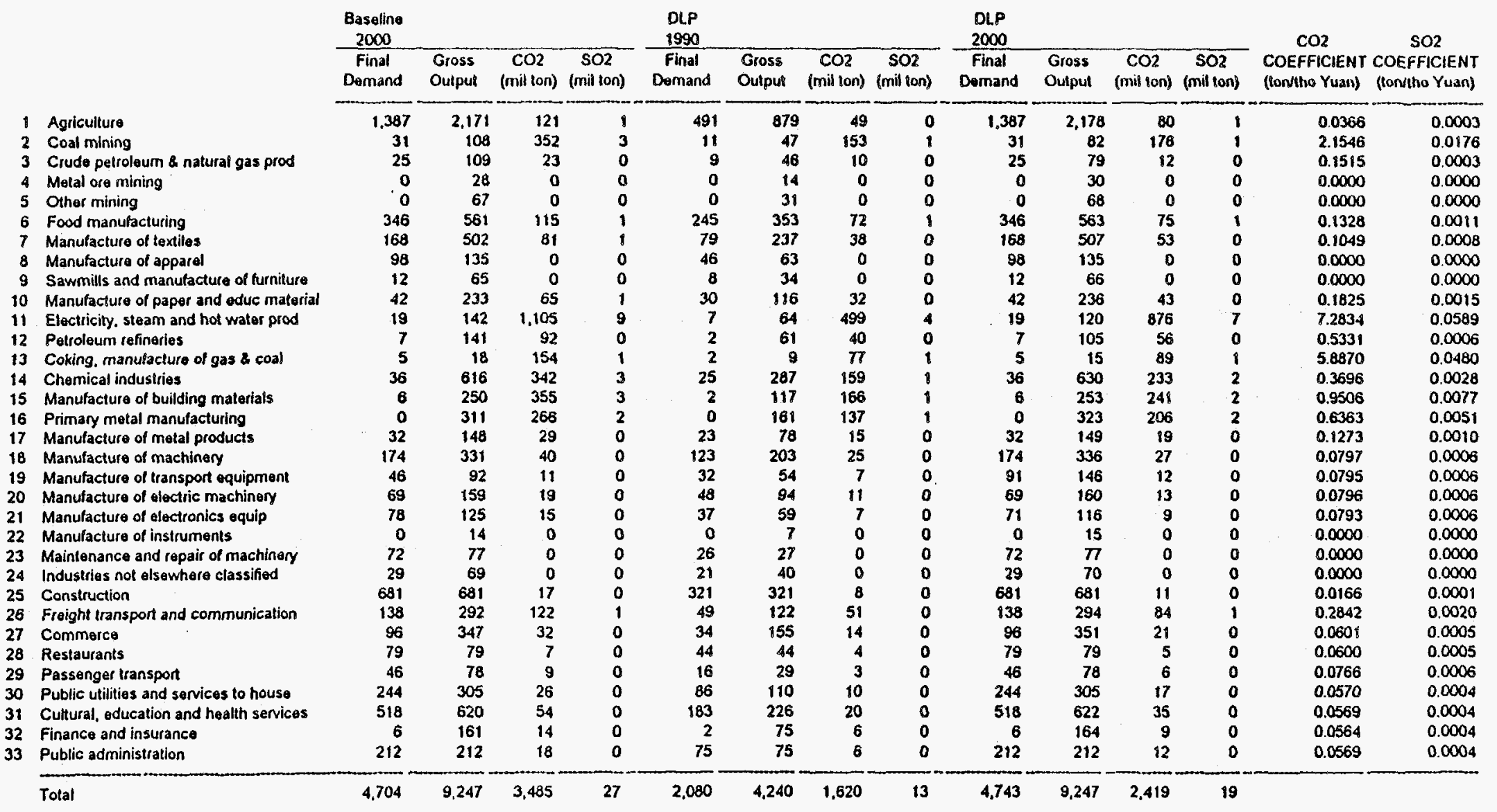

Final Demand and Gross Output in billions of 1990 Yuans

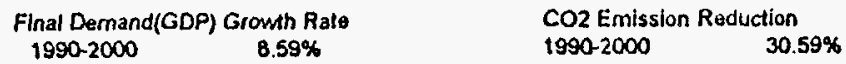




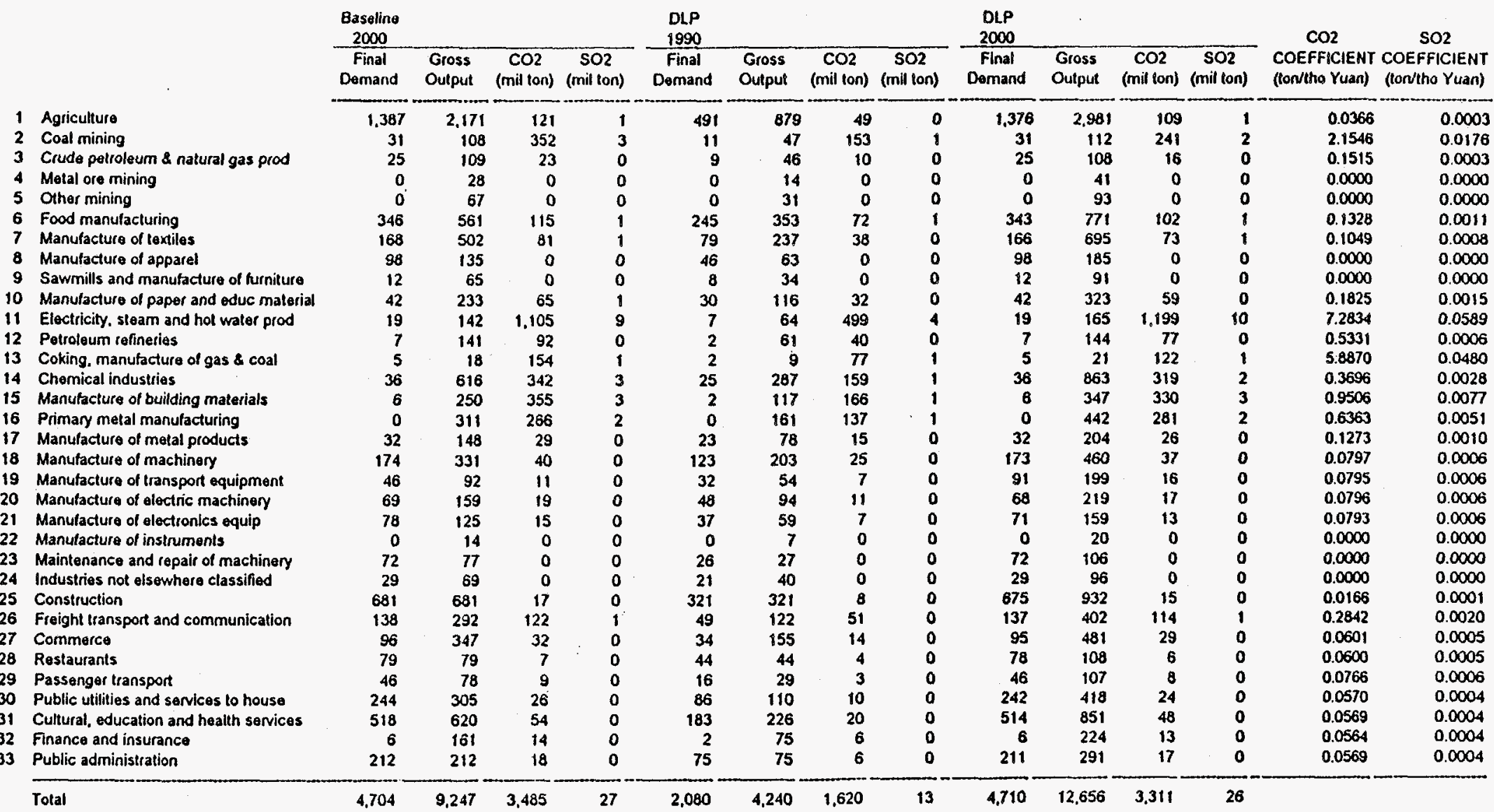

Final Demand and Gross Output in billions of 1990 Yuans
Final Demand(GDP) Growh Rate
$1990-2000 \quad 8.52 \%$
CO2 Emission Reduction
CO2 Emission Reducton 
1 Agriculture

3 Crudo potroleum \& natural gas prod

4 Motal ore mining

5 Other mining

7 Manutacture of texiles

8 Manufacture of apparel

9 Sawmills and manulacluse of furniture

10 Manufacture of paper and oduc material

11 Electricity, steam and hot water prod

12 Petroleum refinerios

13 Coking. manufacture of gas $\$$ coal

14 Chemical industries

15 Manulacture of building materials

16 Primary metal manufacturing

Manufacture of matal products

Manufacture of machinery

Manutactura of transport equipmont

21 Manubcture of electronics oquip

22 Manutacture of instrumests

23 Maintenence and repar of machingry

Ining

25 Construction

25 Constion in

27 Comm

27 Commerce

20 Rassenger unsport

30 Public ulitios and

作

ation and heath services

33 Public admin

Total

\begin{tabular}{|c|c|c|c|c|c|c|c|}
\hline $\begin{array}{c}\text { Baselino } \\
2010\end{array}$ & & & & DLP & & & \\
\hline Final & & & & & & & \\
\hline Domand & Output & (mil lon) & (mil lon) & Demand & Oulput & (mil ton) & (mil fon) \\
\hline
\end{tabular}

DLP Domand Output (millon) (millon) Domand Ousput (mil ton) (mil tons) Demand Output (mit ton) (mil ton) (ton/tho Yuan) (tontho Yuan)

\begin{tabular}{|c|c|c|c|c|c|c|c|c|c|c|c|c|c|}
\hline 2.860 & 4,475 & 249 & 2 & 1.387 & 2,178 & 80 & 1 & 2.860 & 4,487 & 42 & 0 & 0.0093 & 0.0001 \\
\hline 65 & 223 & 726 & 6 & 31 & 82 & 176 & $i$ & 65 & 142 & 57 & 0 & 0.4053 & 0.0033 \\
\hline 52 & 224 & 48 & 0 & 25 & 79 & 12 & 0 & 52 & 142 & 15 & 0 & 0.1091 & 0.0001 \\
\hline 0 & 57 & 0 & D & 0 & 30 & 0 & 0 & 0 & 62 & 0 & 0 & 0.0000 & 0.0000 \\
\hline 1 & 138 & 0 & 0 & 0 & 68 & 0 & 0 & 1 & 139 & 0 & 0 & 0.0000 & 0.0000 \\
\hline 713 & 1.157 & 237 & 2 & 346 & 563 & 75 & 1 & 713 & 1,160 & 29 & 0 & 0.0254 & 0.0002 \\
\hline 346 & 1,035 & 167 & $i$ & 168 & sor & 53 & 0 & 346 & 1,044 & 21 & 0 & 0.0201 & 0.0002 \\
\hline 203 & 278 & 0 & 0 & 98 & 835 & 0 & 0 & 203 & 279 & 0 & 0 & 0.0000 & 0.0000 \\
\hline 25 & 135 & 0 & 0 & 12 & 66 & 0 & 0 & 25 & 136 & 0 & 0 & 0.0000 & 0.0000 \\
\hline 87 & 480 & 134 & 1 & 42 & 236 & 43 & 0 & 87 & 485 & 17 & 0 & 0.0345 & 0.0003 \\
\hline 39 : & 292 & 2278 & 18. & 19. & 120 & 876 & 7 & 39 & 347 & 2,367 & 19 & 6.8225 & 0.0552 \\
\hline 14 & 290 & 189 & 0 & 7 & 105 & 56 & 0 & 14 & 187 & 81 & 0 & 0.4307 & 0.0001 \\
\hline 10 & 38 & 317 & 3 & 5 & 15 & 89 & 1 & 10 & 28 & 21 & 0 & 0.7732 & 0.0063 \\
\hline 74 & 1.270 & 704 & 5 & 36 & 630 & 233 & 2 & 74 & 1,292 & 116 & 1 & 0.0901 & 0.0005 \\
\hline 12 & 516 & 733 & 6 & 6 & 253 & 241 & 2 & 12 & 520 & 93 & 1 & 0.1793 & 0.0014 \\
\hline 0 & 641 & 547 & 4 & 0 & 323 & 206 & 2 & 0 & 673 & 365 & 3 & 0.5423 & 0.0044 \\
\hline 66 & 305 & 59 & 0 & 32 & 149 & 19 & 0 & 66 & 307 & 8 & 0 & 0.0257 & 0.0002 \\
\hline 359 & 683 & 83 & 1 & 174 & 336 & 27 & 0 & 400 & 737 & 12 & 0 & 0.0163 & 0.0001 \\
\hline 94 & 190 & 23 & 0 & 91 & 146 & 12 & 0 & 188 & 301 & 5 & 0 & 0.0162 & 0.0001 \\
\hline 141 & 327 & 40 & 0 & 69 & 160 & 13 & 0 & 141 & $33 i$ & 5 & 0 & 0.0163 & 0.0001 \\
\hline 161 & 257 & 31 & 0 & 71 & 116 & 9 & 0 & 108 & 186 & 3 & 0 & 0.0162 & 0.0001 \\
\hline 0 & 30 & 0 & 0 & 0 & 15 & 0 & 0 & 0 & 30 & 0 & 0 & 0.0000 & 0.0000 \\
\hline 149 & 159 & 0 & 0 & 72 & 77 & 0 & 0 & 149 & 159 & 0 & 0 & 0.0000 & 0.0000 \\
\hline 60 & 143 & 0 & 0 & 29 & 70 & 0 & 0 & 60 & 144 & 0 & 0 & 0.0000 & 0.0000 \\
\hline 1,403 & 1.403 & 35 & 0 & 681 & 681 & 11 & 0 & 1.403 & 1.403 & 8 & 0 & 0.0055 & 0.0000 \\
\hline 285 & 602 & 251 & 2 & 138 & 294 & 84 & 1 & 285 & 606 & 50 & 0 & 0.0824 & 0.0004 \\
\hline 198 & 715 & 66 & $i$ & 96 & 351 & 21 & 0 & 198 & 723 & 9 & 0 & 0.0118 & 0.0001 \\
\hline 163 & 163 & 15 & 0 & 79 & 79 & 5 & 0 & 163 & 163 & 2 & 0 & 0.0118 & 0.0001 \\
\hline 95 & 160 & 18 & 0 & 46 & 78 & 6 & 0 & 95 & 161 & 3 & 0 & 0.0186 & 0.0001 \\
\hline 504 & 628 & 54 & 0 & 244 & 305 & 17 & 0 & 504 & 629 & 9 & 0 & 0.0137 & 0.0008 \\
\hline 1,068 & 1,278 & 110 & 1 & 518 & 622 & 35 & 0 & 1.068 & 1.282 & 18 & 0 & 0.0137 & 0.0001 \\
\hline 12 & 331 & 29 & 0 & 6 & 164 & 9 & 0 & 12 & 337 & 5 & 0 & 0.0135 & 0.0001 \\
\hline 437 & 437 & 38 & 0 & 212 & 212 & 12 & 0 & 437 & 437 & 6 & 0 & 0.0137 & 0.0001 \\
\hline
\end{tabular}

Final Demand and Gross Output in billions of 1990 Yuans

Final Demand(GDP) Growth Rate 2000-2010 $7.50 \%$

CO2 Emission Roduction

$2000-2010 \quad 53.19 \%$ 
1 Agriculture

3 Crude petroleum \& natural gas prod

4 Metal ore mining

Other mining

6 Food manufacturing

Manufacture ol apparel

9 Sawmills and manufacture of furniture

10 Manufacture of paper and oduc materia

11 Electricity, steam and hot water prod

12 Petroleum refineries

13 Coking, manufacture of gas \& coal

14 Chemical industries

15 Manufacture of building materials

16 Primary metal manufacturing

17 Manufacture of metal products

18 Manufacture of machinery

19 Manufacture of transport equipment

20 Manufacture of eloctric machinery

21 Manulacture of electronics oquip

22 Manufacture of instruments

23 Maintenance and repair of machinery

24 Industries not elsewhere classified

25 Consiruction

26 Froight transport and communication

27 Commerce

28 Restaurants

29 Passenger transport

Public utitities and services to houso

31 Cultural, education and health services

32 Finance and insurance

Public administration

Total

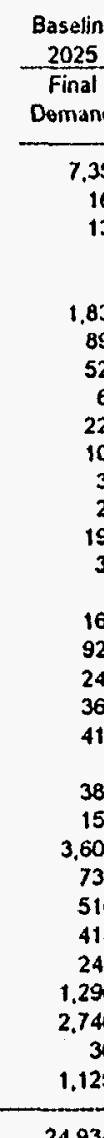

DLP

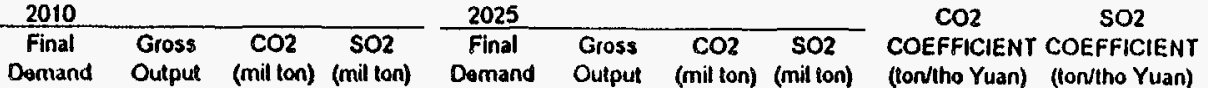

\begin{tabular}{|c|c|c|c|c|c|c|c|c|c|c|c|c|}
\hline & & & & 2010 & & & & 2023 & & & & . \\
\hline $\begin{array}{l}\text { Final } \\
\text { Domand }\end{array}$ & $\begin{array}{l}\text { Gross } \\
\text { Outpus }\end{array}$ & $\begin{array}{c}\mathrm{CO2} \\
\text { (mil ton) }\end{array}$ & $\begin{array}{c}\mathrm{SO} 2 \\
\text { (mil ton) }\end{array}$ & $\begin{array}{c}\text { Final } \\
\text { Domand }\end{array}$ & $\begin{array}{l}\text { Gross } \\
\text { Output }\end{array}$ & $\begin{array}{c}\mathrm{CO} 2 \\
\text { (mil ton) }\end{array}$ & $\begin{array}{c}\mathrm{SO2} \\
\text { (mil ton) }\end{array}$ & $\begin{array}{c}\text { Final } \\
\text { Demand }\end{array}$ & $\begin{array}{l}\text { Gross } \\
\text { Output }\end{array}$ & $\begin{array}{c}\mathrm{CO} 2 \\
\text { (mil ton) }\end{array}$ & $\begin{array}{c}\mathrm{SO2} \\
\text { (mil ion) }\end{array}$ & $\begin{array}{l}\text { COEFFICIENT COEFFICIEN } \\
\text { (ton/tho Yuan) (ton/tho Yuan) }\end{array}$ \\
\hline
\end{tabular}

\begin{tabular}{|c|c|c|c|c|c|c|c|c|c|c|c|c|c|}
\hline 7.354 & 11.509 & 641 & 5 & 2,860 & 4.487 & 42 & 0 & 7,354 & 11.544 & 32 & 0 & 0.0028 & 0.0000 \\
\hline 167 & 574 & 1868 & 15 & 65 & 142 & 57 & 0 & 167 & 318 & 1 & 0 & 0.0039 & 0.0000 \\
\hline 134 & 577 & 124 & 0 & 52 & 142 & 15 & 0 & 134 & 356 & ji & 0 & 0.0867 & 0.0000 \\
\hline 0 & 146 & 0 & 0 & 0 & 62 & 0 & 0 & 0 & 163 & 0 & 0 & 0.0000 & 0.0000 \\
\hline 2 & 355 & 0 & 0 & 1 & 139 & 0 & 0 & 2 & 359 & 0 & 0 & 0.0000 & 0.0000 \\
\hline 1.033 & 2,975 & 608 & 5 & 713 & 1.160 & 29 & 0 & 1.833 & 2,984 & 2 & 0 & 0.0007 & 0.0000 \\
\hline 890 & 2,663 & 430 & 3 & 346 & $8,0-44$ & 21 & 0 & 890 & 2,689 & 2 & 0 & 0.0007 & 0.0000 \\
\hline 522 & 714 & 0 & 0 & 203 & 279 & 0 & 0 & 522 & 717 & 0 & 0 & 0.0000 & 0.0000 \\
\hline 63 & 346 & 0 & 0 & 25 & 136 & 0 & 0 & 63 & 351 & 0 & 0 & 0.0000 & 0.0000 \\
\hline 223 & 1.235 & 346 & 3 & 87 & 485 & 17 & 0 & 223 & 1.249 & 1 & 0 & 0.0006 & 0.0000 \\
\hline 101 & 750 & 5859 & 47 & 39 & 347 & 2,367 & 19 & 101 & 895 & 5,577 & 45 & 6.2321 & 0.0503 \\
\hline 37 & 745 & 486 & 1 & 14 & 187 & 81 & 0 & 37 & 461 & 178 & 0 & 0.3862 & 0.0000 \\
\hline 25 & 97 & 816 & 7 & 10 & 28 & 21 & 0 & 25 & 67 & 0 & 0 & 0.0058 & 0.0000 \\
\hline 190 & 3,266 & 1810 & 14 & 74 & 1,292 & 116 & 1 & 190 & 3,333 & 78 & 0 & 0.0234 & 0.0000 \\
\hline 31 & 1,327 & 1884 & 15 & 12 & 520 & 93 & $i$ & 31 & 1.341 & 11 & 0 & 0.0079 & 0.0000 \\
\hline 0 & 1,648 & 1408 & 11 & 0 & 673 & 365 & 3 & 0 & $1.74 t$ & 851 & 7 & 0.4891 & 0.0039 \\
\hline 169 & 784 & 152 & 1 & 66 & 307 & 8 & 0 & 169 & 791 & 2 & 0 & 0.0022 & 0.0000 \\
\hline 924 & 1.757 & 214 & 2 & 400 & 737 & 12 & 0 & 1,054 & 1.925 & 3 & 0 & 0.0016 & 0.0000 \\
\hline 242 & 489 & 60 & 0 & 188 & 301 & 5 & 0 & 484 & 775 & $i$ & 0 & 0.0016 & 0.0000 \\
\hline 363 & 841 & 102 & 1 & 141 & 331 & 5 & 0 & 363 & 853 & i & 0 & 0.0016 & 0.0000 \\
\hline 414 & 662 & 81 & $i$ & 108 & 186 & 3 & 0 & $2 \pi 7$ & 479 & $i$ & 0 & 0.0016 & 0.0000 \\
\hline 0 & 76 & 0 & 0 & 0 & 30 & 0 & 0 & 0 & $\pi$ & 0 & 0 & 0.0000 & 0.0000 \\
\hline 384 & 408 & 0 & 0 & 149 & 159 & 0 & 0 & 384 & 409 & 0 & 0 & 0.0000 & 0.0000 \\
\hline 156 & 367 & 0 & 0 & 60 & 144 & 0 & 0 & 156 & 371 & 0 & 0 & 0.0000 & 0.0000 \\
\hline 3,609 & 3.609 & 90 & 1 & 1,403 & 1.403 & 8 & 0 & 3,609 & 3.609 & 9 & 0 & 0.0025 & 0.0000 \\
\hline 732 & 1,549 & 644 & 5 & 285 & 608 & so & 0 & 732 & 1,560 & 52 & 0 & 0.0334 & 0.0000 \\
\hline 510 & 1.838 & 169 & 1 & 198 & 723 & 9 & 0 & 510 & 1,861 & 1 & 0 & 0.0007 & 0.0000 \\
\hline 418 & 418 & 39 & 0 & 163 & 163 & 2 & 0 & 418 & 418 & 0 & 0 & 0.0007 & 0.0000 \\
\hline 245 & 412 & 47 & 0 & 95 & 161 & 3 & 0 & 245 & 415 & 2 & 0 & 0.0048 & 0.0000 \\
\hline 1,296 & 1,614 & 140 & 1 & 504 & 629 & 9 & 0 & 1.296 & 1.619 & 6 & 0 & 0.0035 & 0.0000 \\
\hline 2.746 & 3.286 & 284 & 2 & 1.068 & 1.282 & 18 & 0 & 2,746 & 3.297 & 12 & 0 & 0.0035 & 0.0000 \\
\hline 30 & 851 & 74 & 1 & 12 & 337 & 5 & 0 & 30 & 868 & 3 & 0 & 0.0034 & 0.0000 \\
\hline 1,125 & 1.125 & 97 & 1 & 437 & 437 & 6 & 0 & 1.125 & 1.125 & 4 & 0 & 0.0035 & 0.0000 \\
\hline
\end{tabular}

Final Demand and Gross Output in billions of 1990 Yuans

Final Demand(GDP) Growth Rate $\quad \mathrm{CO}$ Emission Reduction

Final Demand(GDP) Growth Rate $\quad$ CO2 Emission Reduction




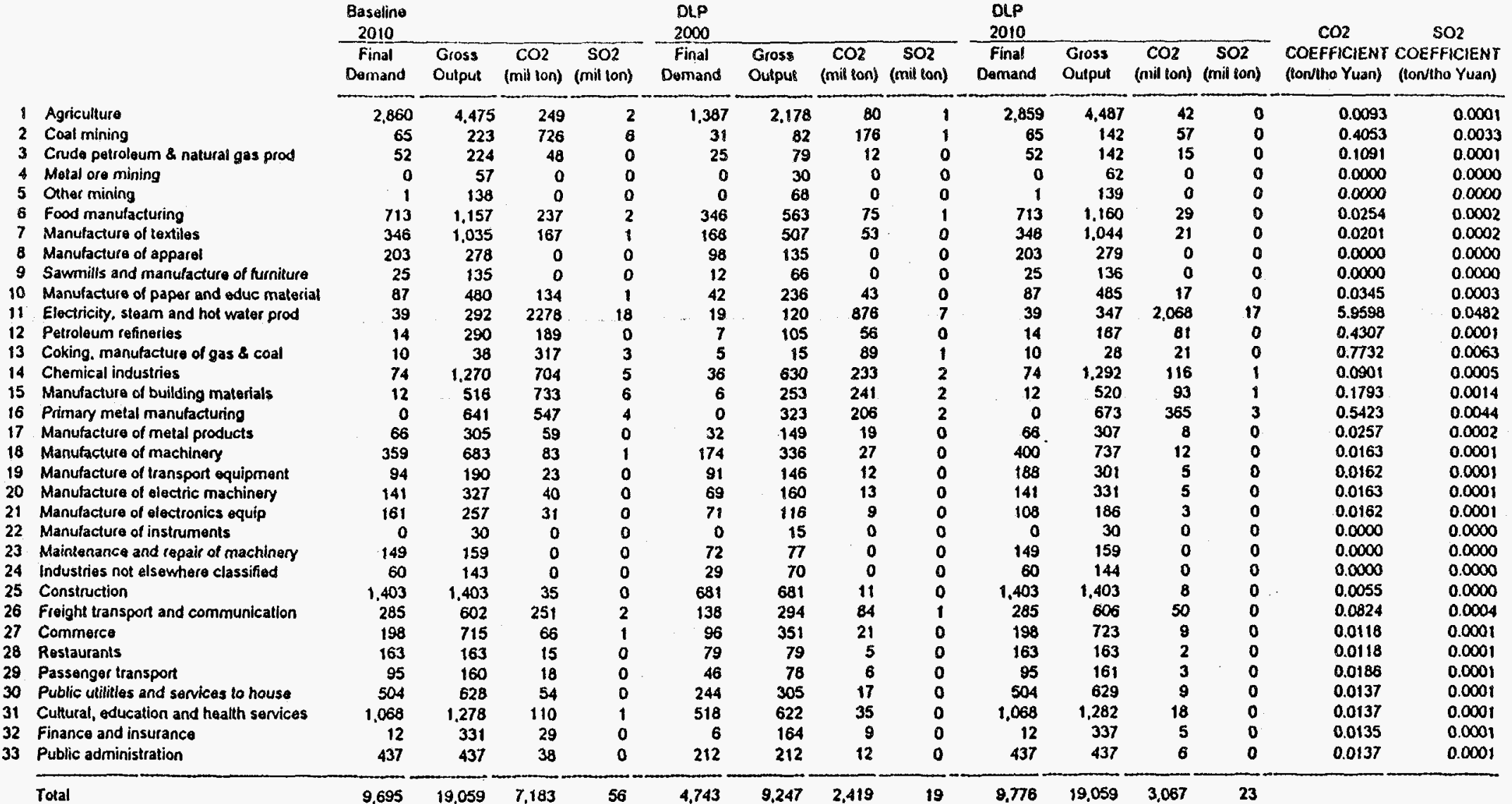

Final Demand and Gross Output in billions of 1990 Yuans

$\begin{array}{cc}\text { Final Demand(GDP) Growth Rate } \\ 2000-2010 & \text { CO2 Emisston Roduction }\end{array}$
2000-2010
$7.50 \%$ 


\begin{tabular}{|c|c|c|c|c|c|c|c|c|c|c|c|c|c|c|c|c|c|c|c|c|c|c|c|c|c|c|c|c|c|}
\hline & \multirow{2}{*}{\multicolumn{2}{|c|}{$\begin{array}{l}\text { Gross } \\
\text { Output }\end{array}$}} & \multirow{2}{*}{\multicolumn{2}{|c|}{$\begin{array}{c}\mathrm{SO}^{\mathrm{SO}} \\
\text { (mil ton) }\end{array}$}} & \multirow{2}{*}{\multicolumn{2}{|c|}{$\begin{array}{l}\text { Gross } \\
\text { Output }\end{array}$}} & \multirow{2}{*}{\multicolumn{2}{|c|}{$\begin{array}{c}\mathrm{SO2} \\
\text { (mil lon) }\end{array}$}} & & & & \multirow{2}{*}{\multicolumn{2}{|c|}{$\begin{array}{c}\mathrm{CO} 2 \\
\text { COEFFICIENT } \\
\text { (ton/ho Yuan) }\end{array}$}} & & & & & & & & & & & & & & & \\
\hline & & & & & & & & & & & & & & & & & & & & & & & & $\begin{array}{c}\text { Final } \\
\text { Demand }\end{array}$ & $\begin{array}{l}\text { Gross } \\
\text { Output }\end{array}$ & (mil ton) & $\begin{array}{l}\mathrm{SO} 2 \\
\text { (mil ton) }\end{array}$ & & \\
\hline 1 Agriculture & & & & & & & 42 & $\mathbf{0}$ & & & & & & & griculture & 7.354 & 11.509 & 641 & 5 & 2,859 & 4.487 & & o & 7,354 & 11,544 & 32 & 0 & 0.0028 & 0.0000 \\
\hline 2 Coal mining & & & & & & & 57 & & & & & & & & oal mining & 167 & 574 & 1868 & 15 & 65 & 142 & & 0 & 167 & 318 & 1 & $\mathbf{0}$ & 0.0039 & 0.0000 \\
\hline 3 Crude petroleum \& natural gas prod & & & & & & & 15 & & & & & & & & rude petroloum \& natural gas prod & 134 & 57 & 124 & 0 & 52 & 142 & & 0 & 134 & 356 & 31 & $\mathbf{0}$ & 0.0867 & 0.0000 \\
\hline 4 Motal ore mining & & & & & & & 0 & & & & & & & & atal ore mining & $\mathbf{0}$ & 148 & 0 & 0 & 0 & 62 & & 0 & $\mathbf{0}$ & 163 & 0 & o & 0.0000 & 0.0000 \\
\hline Other mining & & & & & & & $\mathbf{0}$ & & & & & & & & ther mining & 2 & 355 & 0 & $\mathbf{0}$ & 1 & 139 & & 0 & 2 & 359 & 0 & $\mathbf{0}$ & 0.0000 & 0.0000 \\
\hline Food manufacturing & & & & & & & 29 & & & & & & & & ood manufacturing & 1,833 & 2.975 & 608 & 5 & 713 & 8.160 & & o & 1,033 & 2,984 & 2 & 0 & 0.0007 & 0.0000 \\
\hline Manufacture of lextiles & & & & & & & 21 & & & & & & & & lanufacture of lextiles & 890 & 2.663 & 430 & 3 & 346 & 1.044 & & 0 & 890 & 2.689 & 2 & 0 & 0.0007 & 0.0000 \\
\hline Manutacture of apparel & & & & & & & 0 & & & & & & & & anutacture of appacel & 522 & 714 & 0 & 0 & 203 & 279 & & 0 & 522 & 717 & 0 & 0 & 0.0000 & 0.0000 \\
\hline Sawrnills and manufacture of furniture & & & & & & & 0 & & & & & & & & awnills and manufacture of furniture & 63 & 346 & 0 & 0 & 25 & 136 & & 0 & 63 & Jsi & 0 & 0 & 0.0000 & 0.0000 \\
\hline Manufacture of paper and oduc material & & & & & & & $\$ 7$ & & & & & & & & lanufacture of paper and oduc material & 223 & 1.235 & 346 & 3 & 87 & 485 & & 0 & 223 & 1.249 & 1 & $\mathbf{0}$ & 0.0006 & 0.0000 \\
\hline & & & & & & & & & & & & & & & lectricity, steam and hot waler prod & 101 & 750 & 5859 & 47 & 39 & 347 & 2,06 & 17 & 101 & 895 & 1.504 & 12 & 1.6805 & 0.0133 \\
\hline & & & & & & & 81 & & & & & & & & etroleum refineries & 37 & 745 & 486 & 1 & 14 & 187 & & 0 & 37 & 461 & 178 & 0 & 0.3862 & 0.0000 \\
\hline & & & & & & & & & & & & & & & oking. manufacture of gas \& coal & 25 & 97 & 816 & 7 & 10 & 28 & 2 & 0 & 25 & 67 & 0 & 0 & 0.0058 & 0.0000 \\
\hline & & & & & & & & & & & & & & & hemical industries & 190 & 3.266 & 1810 & 14 & 74 & 1.292 & 11 & 1 & 190 & 3.333 & 78 & 0 & 0.0234 & 0.0000 \\
\hline & & & & & & & 93 & & & & & & & & anufacture of building materials & 31 & 1.327 & 1884 & 15 & 12 & 520 & 9 & 1 & 31 & 1,341 & 11 & 0 & 0.0079 & 0.0000 \\
\hline & & & & & & & & & & & & & & & imary metal manufacturing & 0 & 1,648 & 1408 & 11 & 0 & 673 & 36 & 3 & 0 & 1.741 & 851 & 7 & 0.4891 & 0.0039 \\
\hline & & & & & & & 8 & & & & & & & & anufacture of melal products & 169 & 784 & 152 & $\mathbf{t}$ & 66 & 307 & & 0 & 169 & 791 & 2 & $\mathbf{0}$ & 0.0022 & 0.0000 \\
\hline & & & & & & & & & & & & & & & anufacture of machinery & 924 & 1.757 & 214 & 2 & 400 & 737 & 1 & 0 & 1.054 & 1.925 & 3 & 0 & 0.0016 & 0.0000 \\
\hline & & & & & & & 5 & & & & & & & & anufacture of transport equipment & 242 & 489 & 60 & 0 & 188 & 301 & & 0 & 484 & 775 & 1 & 0 & 0.0016 & 0.0000 \\
\hline & & & & & & & 5 & & & & & & & & anufacture of electric machinery & 363 & 841 & 102 & 1 & 141 & 331 & & o & 363 & 853 & $i$ & 0 & 0.0016 & 0.0000 \\
\hline & & & & & & & 3 & & & & & & & & anufacture of efoctronlcs equip & 414 & 662 & 81 & $i$ & 108 & 186 & & 0 & $2 \pi$ & 479 & $\mathbf{i}$ & 0 & 0.0016 & 0.0000 \\
\hline & & & & & & & 0 & & & & & & & & anufacture of instruments & 0 & 76 & 0 & 0 & 0 & 30 & & 0 & 0 & $\pi$ & 0 & 0 & 0.0000 & 0.0000 \\
\hline & & & & & & & 0 & & & & & & & & aintenance and repair of machinery & 384 & 408 & 0 & 0 & 149 & 159 & & 0 & 384 & 409 & 0 & $\mathbf{0}$ & 0.0000 & 0.0000 \\
\hline & & & & & & & 0 & & & & & & & & dustries not elsewhiere classified & 156 & 367 & 0 & 0 & 60 & 144 & & 0 & 156 & 371 & 0 & 0 & 0.0000 & 0.0000 \\
\hline & & & & & & & a & & & & & & & & enstruction & 3.609 & 3.609 & 90 & 1 & 1.403 & 1.403 & & 0 & 3.609 & 3.609 & 9 & $\mathbf{0}$ & 0.0025 & 0.0000 \\
\hline & & & & & & & 50 & & & & & & & & dight transport and communication & 732 & 1.549 & 644 & 5 & 285 & 606 & 5 & 0 & 732 & 1,560 & 52 & 0 & 0.0334 & 0.0000 \\
\hline & & & & & & & 9 & & & & & & & & ommerce & 510 & 1.838 & 169 & 1 & 198 & 723 & & 0 & 510 & 1,861 & 1 & 0 & 0.0007 & 0.0000 \\
\hline & & & & & & & 2 & & & & & & & & estaurants & 418 & 418 & 39 & 0 & 163 & 163 & ? & 0 & 418 & 418 & 0 & 0 & 0.0007 & 0.0000 \\
\hline & & & & & & & 3 & & & & & & & & assenger transport & 245 & 412 & 47 & 0 & 95 & 161 & & $\mathbf{0}$ & 245 & 415 & 2 & 0 & 0.0048 & 0.0000 \\
\hline & & & & & & & 9 & & & & & & & & blic utilities and services to house & 1.296 & 1.614 & 140 & 1 & 504 & 629 & $s$ & 0 & 1.296 & 1.619 & 6 & 0 & 0.0035 & 0.0000 \\
\hline & & & & & & & 18 & & & & & & & & Atural, education and health services & 2,746 & 3.286 & 284 & 2 & 1.068 & 1,282 & 18 & 0 & 2,746 & 3.297 & 12 & 0 & 0.0035 & 0.0000 \\
\hline & & & & & & & 5 & & & & & & & & nance and insurance & 30 & 851 & 74 & 1 & 12 & 337 & 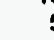 & 0 & 30 & 868 & 3 & 0 & 0.0034 & 0.0000 \\
\hline & & & & & & & 6 & & & & & & & & blic administration & 1.125 & 1.125 & 97 & $i$ & 437 & 437 & 6 & 0 & 1,125 & 1,125 & 4 & 0 & 0.0035 & 0.0000 \\
\hline Total & & & & & & & & & & & & & & & (a) & 24,934 & 49.016 & 18,474 & 143 & 9,776 & 19,059 & 3,067 & 23 & 25.170 & 49,016 & 2,788 & 19 & & \\
\hline
\end{tabular}

Final Domand and Gross Output in billions of 1990 Yuans

\begin{tabular}{|c|c|}
\hline Final Demand(GDP) Growth Rat & CO2 Emission Reduction \\
\hline $2010-2025$ & $2010-2025$ \\
\hline
\end{tabular}


APPENDIX A2:

LOWER-BOUND SIMULATIONS 



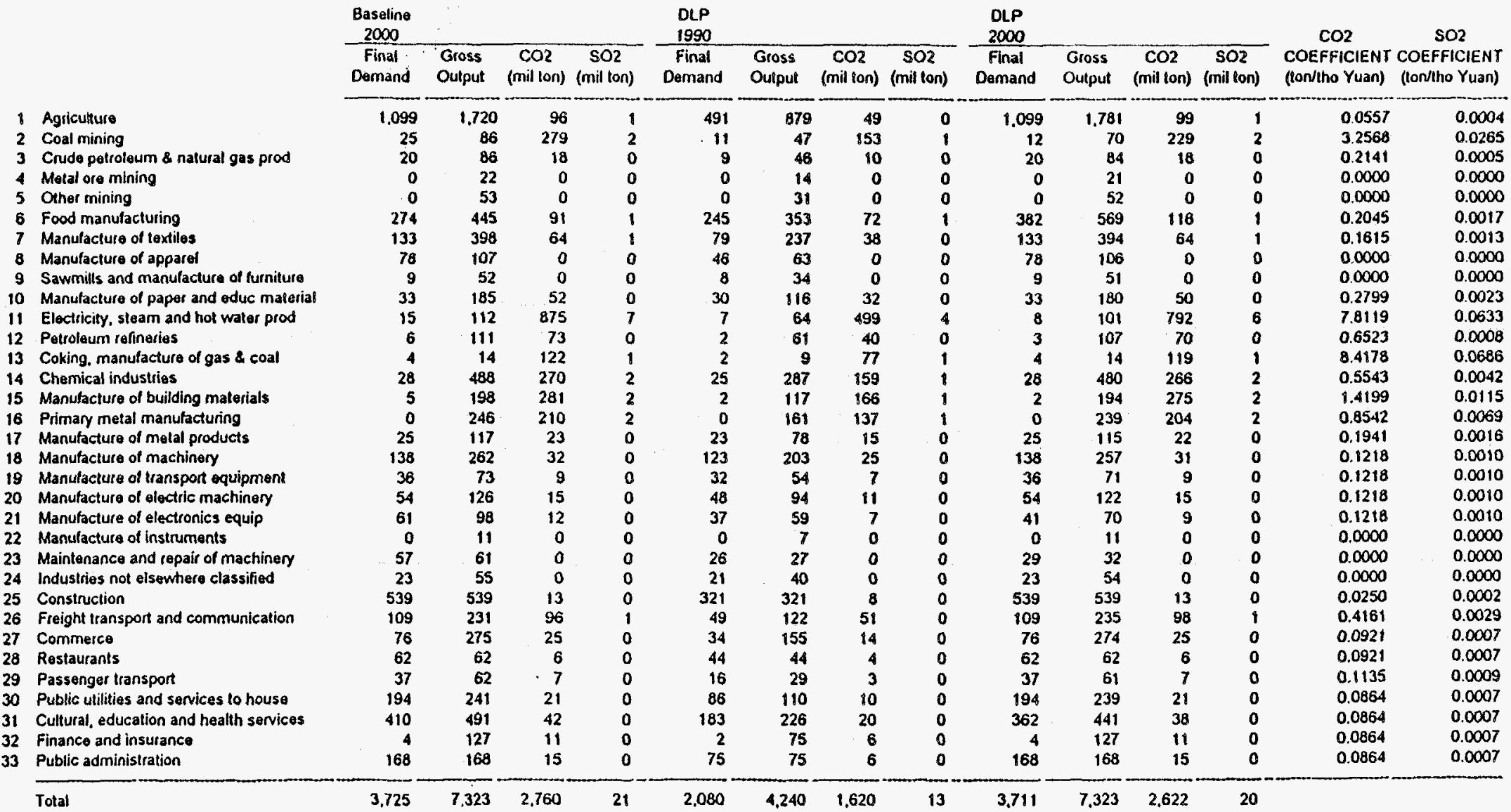

Final Demand and Gross Output in billions of 1990 Yuans
Final Demand(GDP) Growth Rate
$\begin{aligned} & 1990.2000 \\ & 5.96 \%\end{aligned}$
CO2 Emission Reduction
$5.96 \%$
1990-2000 


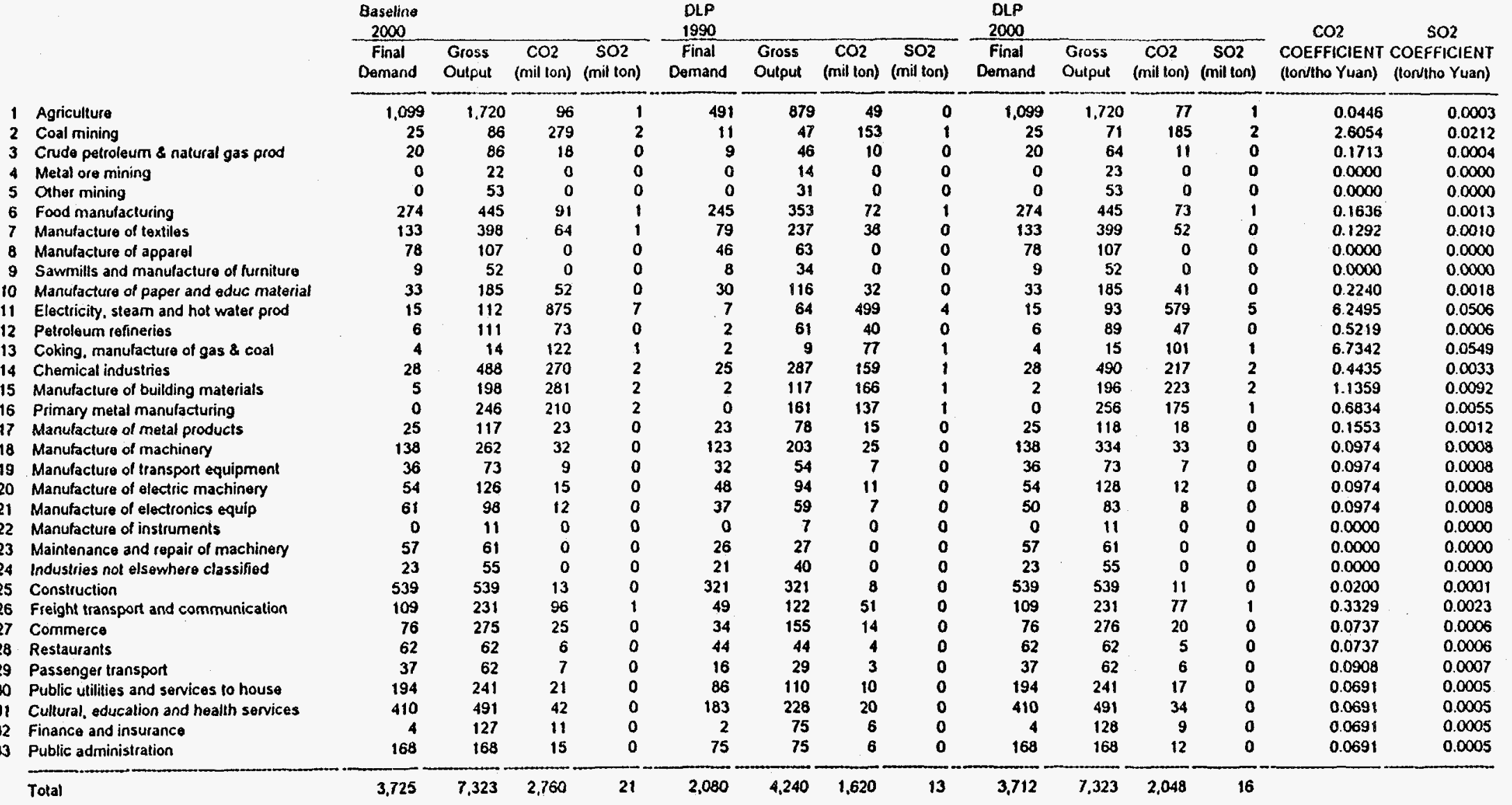

Finat Demand and Gross Output in billions of 1990 Yuans
Final Dernand(GOP) Growhth Rate
1990.2000
$5.96 \%$
CO2 Emission Reduction
1990-2000 


\begin{tabular}{|c|c|c|c|c|c|c|c|c|c|c|c|c|c|c|}
\hline & $\begin{array}{c}\text { Baselina } \\
2000 \\
\end{array}$ & & & & $\begin{array}{c}\text { DLP } \\
1990\end{array}$ & & & & $\begin{array}{r}\text { OLP } \\
2000 \\
\end{array}$ & & & & $\mathrm{CO} 2$ & $\mathrm{SO} 2$ \\
\hline & $\begin{array}{c}\text { Final } \\
\text { Domand }\end{array}$ & $\begin{array}{l}\text { Gross } \\
\text { Ousput }\end{array}$ & $\begin{array}{c}\mathrm{CO} 2 \\
\text { (mil ton) }\end{array}$ & $\begin{array}{c}\mathrm{SO} 2 \\
\text { (mil ton) }\end{array}$ & $\begin{array}{c}\text { Final } \\
\text { Demand }\end{array}$ & $\begin{array}{l}\text { Gross } \\
\text { Outpur }\end{array}$ & $\begin{array}{c}\mathrm{CO} \\
\text { (mil ton) }\end{array}$ & $\begin{array}{c}\mathrm{SO2} \\
\text { (mil ton) }\end{array}$ & $\begin{array}{c}\text { Final } \\
\text { Demand }\end{array}$ & $\begin{array}{l}\text { Gross } \\
\text { Oulput }\end{array}$ & $\begin{array}{c}\mathrm{CO2} \\
\text { (mil ton) }\end{array}$ & $\frac{502}{\text { (mil fon) }}$ & $\begin{array}{l}\text { COEFFICIENT } \\
\text { (lonitho Yuan) }\end{array}$ & $\begin{array}{l}\text { COEFFICIENT } \\
\text { (Ior/tho Yuan) }\end{array}$ \\
\hline 1 Agriculture & 1.099 & 1.720 & 96 & 1 & 491 & 879 & 49 & $\mathbf{0}$ & 1.102 & 2.202 & 90 & 1 & 0.0446 & 0.0003 \\
\hline 2 Coal mining & 25 & 86 & 279 & 2 & 11 & 47 & 153 & 1 & 25 & 91 & 237 & 2 & 2.6054 & 0.0212 \\
\hline 3 Crude petroleum \& natural gas prod & 20 & 86 & 18 & $\mathbf{0}$ & 9 & 46 & 10 & $\mathbf{0}$ & 20 & 82 & 14 & 0 & 0.1713 & 0.0004 \\
\hline 4 Metal ore mining & D & 22 & 0 & 0 & 0 & 14 & 0 & $\mathbf{0}$ & 0 & 29 & $\mathbf{0}$ & 0 & 0.0000 & 0.0000 \\
\hline 5 Other mining & $\mathbf{0}$ & 53 & 0 & 0 & 0 & 31 & 0 & 0 & 0 & 68 & $\mathbf{0}$ & 0 & 0.0000 & 0.0000 \\
\hline Food manulacturing & 274 & 445 & 91 & 1 & 245 & 353 & 72 & 1 & 275 & 569 & 93 & 1 & 0.1636 & 0.0013 \\
\hline Manufacture of textites & 133 & 398 & 64 & 8 & 79 & 237 & 38 & 0 & 133 & 510 & 66 & $i$ & 0.1292 & 0.0010 \\
\hline Manufacture of apparol & 78 & 107 & 0 & 0 & 46 & 63 & 0 & 0 & 78 & 137 & 0 & 0 & 0.0000 & 0.0000 \\
\hline Sawmills and manufacture of furnisure & 9 & 52 & 0 & 0 & 8 & 34 & 0 & 0 & 9 & 67 & 0 & 0 & 0.0000 & 0.0000 \\
\hline Manufacture of paper and educ material & 33 & 185 & 52 & 0 & 30 & 116 & 32 & 0 & 33 & 237 & 53 & 0 & 0.2240 & 0.0018 \\
\hline Eloctricity, steam and hot water prod & 15 & 112 & 875 . & 7. & 7 & 64 & 499 & 4 & 15 & 119 & 741 & 6 & 6.2495 & 0.0506 \\
\hline Palroloum refineries & 6 & 111 & 73 & 0 & 2 & 61 & 40 & 0 & 6 & 114 & 60 & 0 & 0.5219 & 0.0006 \\
\hline Coking, manufacture of gas $\&$ coal & 4 & 14 & 122 & 1 & 2 & 9 & 77 & 1 & 4 & 19 & 129 & $i$ & 6.7342 & 0.0549 \\
\hline Chemical industries & 28 & 488 & 270 & 2 & 25 & 287 & 159 & $i$ & 29 & 627 & 278 & 2 & 0.4435 & 0.0033 \\
\hline Manufacture of building materials & $\mathbf{s}$ & 198 & 281 & 2 & 2 & 117 & 166 & $i$ & 2 & 251 & 285 & 2 & 1.1359 & 0.0092 \\
\hline Primary metal manufacturing & 0 & 246 & 210 & 2 & $\ddot{0}$ & 861 & 137 & 1 & 0 & 328 & 224 & 2 & 0.6834 & 0.0055 \\
\hline Manufacture of metal products & 25 & 117 & 23 & 0 & 23 & 78 & 15 & 0 & 25 & 151 & 24 & 0 & 0.1553 & 0.0012 \\
\hline Manufacture of machinery & 138 & 262 & 32 & 0 & 123 & 203 & 25 & 0 & 138 & 428 & 42 & 0 & 0.0974 & 0.0008 \\
\hline Manufacture of transport equipment & 36 & 73 & 9 & 0 & 32 & 54 & 7 & 0 & 36 & 94 & 9 & o & 0.0974 & 0.0008 \\
\hline Manufacture of electric machinery & 54 & 126 & 15 & 0 & 48 & 94 & 11 & 0 & 54 & 164 & 16 & 0 & 0.0974 & 0.0008 \\
\hline Manufacture of electronics equip & 61 & 98 & 12 & 0 & 37 & 59 & 7 & 0 & 50 & 107 & 10 & 0 & 0.0974 & 0.0008 \\
\hline Manufacture of instruments & 0 & 11 & 0 & 0 & 0 & 7 & 0 & 0 & 0 & 15 & 0 & 0 & 0.0000 & 0.0000 \\
\hline Maintenance and tepair of machinery & 57 & 61 & 0 & 0 & 26 & 27 & 0 & 0 & 58 & 78 & 0 & 0 & 0.0000 & 0.0000 \\
\hline Industries not alsowhere classified & 23 & 55 & 0 & 0 & 21 & 40 & 0 & 0 & 23 & 70 & 0 & 0 & 0.0000 & 0.0000 \\
\hline Construction & 539 & 539 & 13 & 0 & 321 & 321 & 8 & 0 & 541 & 690 & 14 & 0 & 0.0200 & 0.0001 \\
\hline Froight transport and communication & 109 & 231 & 96 & $i$ & 49 & 122 & 51 & 0 & 110 & 296 & 99 & 1 & 0.3329 & 0.0023 \\
\hline Commerco & 76 & 275 & 25 & 0 & 34 & 155 & 14 & 0 & 76 & 353 & 26 & 0 & 0.0737 & 0.0006 \\
\hline Restaurants & 62 & 62 & 6 & 0 & 44 & 44 & 4 & 0 & 63 & 80 & 6 & 0 & 0.0737 & 0.0006 \\
\hline Passenger transport & 37 & 62 & 7 & 0 & 16 & 29 & 3 & 0 & 37 & 79 & 7 & 0 & 0.0908 & 0.0007 \\
\hline Public utilities and services to house & 194 & 241 & 21 & 0. & 86 & 110 & 10 & 0 & 194 & 309 & 21 & 0 & 0.0691 & 0.0005 \\
\hline Cultural, education and health services & 410 & 491 & 42 & 0 & 183 & 226 & 20 & 0 & 412 & 629 & 43 & 0 & 0.0691 & 0.0005 \\
\hline Finance and insurance & 4 & 127 & 11 & 0 & 2 & 75 & 6 & 0 & 5 & 164 & 11 & 0 & 0.0691 & 0.0005 \\
\hline Public administration & 168 & 168 & 15 & 0 & 75 & 75 & 6 & 0 & 169 & 215 & 15 & 0 & 0.0691 & 0.0005 \\
\hline Tola & 3.725 & 7,323 & 2,760 & 21 & 2.080 & 4.240 & 1,620 & 13 & 3,723 & 9,373 & 2.622 & 20 & & \\
\hline
\end{tabular}

Final Demand and Gross Output in billions of 1990 Yuans

Final Demand(GDP) Growth Rato $1990-2000$
$5.99 \%$
$\mathrm{CO} 2$ Emission Reduction

$1990-2000 \quad 5.00 \%$ 


\section{Agricullure}

2 Coal mining

Crude petroleum \& natural gas prod

Motal ore mining

Oher mining.

Food manufacturing

Manufacture of appares

Sawmills and manufacture of furniture

10 Manufacture of paper and oduc material

11 Eloctricity, steam and hot water prod

12 Potroleum refineries

13 Coking. manufacture of gas \& coal

14 Chemical industries

15 Manufacture of building materials

16 Primary motal manutacturing

17 Manufacture of motal produets

18 Manufacture of machinery

19 Manufacture of transport equipment

20 Manufacture of electric machinery

21 Manulacture of electronics equip

23 Maintenance and repair of machinery

24 Industries not elsewhere classified

25 Construction

26 Freight transport and communication 27 Commerce

28 Restaurants

29 Passenger transport

30 Public utilities and services to house

31 Cultural, education and health services

32 Finance and insurance

33 Public administration

Total -5.514

\begin{tabular}{|c|c|c|c|c|c|c|c|c|c|c|c|c|c|}
\hline \multirow{2}{*}{$\begin{array}{c}\text { Baseline } \\
2010 \\
\text { Final } \\
\text { Demand }\end{array}$} & \multicolumn{7}{|c|}{$\begin{array}{r}\text { DLP } \\
2000 \\
\end{array}$} & \multicolumn{4}{|l|}{$\begin{array}{r}\text { DLP } \\
2010 \\
\end{array}$} & \multirow{2}{*}{$\begin{array}{c}\mathrm{CO} 2 \\
\text { COEFFICIENT } \\
\text { (toritho Yuan) }\end{array}$} & \multirow{2}{*}{$\begin{array}{c}\text { SO2 } \\
\text { COEFFICIENT } \\
\text { (tor/tho Yuan) }\end{array}$} \\
\hline & $\begin{array}{l}\text { Gross } \\
\text { Oulput }\end{array}$ & $\begin{array}{c}\mathrm{CO} 2 \\
\text { (mil ton) }\end{array}$ & $\begin{array}{c}\mathrm{SO2} \\
\text { (mil ton) }\end{array}$ & $\begin{array}{c}\text { Final } \\
\text { Demand }\end{array}$ & $\begin{array}{l}\text { Gross } \\
\text { Outpul }\end{array}$ & $\begin{array}{c}\mathrm{CO} 2 \\
\text { (mil ton) }\end{array}$ & $\begin{array}{c}\mathrm{SO}^{\mathrm{SO}} \\
\text { (mil ton) }\end{array}$ & $\begin{array}{c}\text { Final } \\
\text { Demand }\end{array}$ & $\begin{array}{l}\text { Gross } \\
\text { Output }\end{array}$ & $\begin{array}{c}\mathrm{CO} 2 \\
\text { (mil ton) }\end{array}$ & $\begin{array}{c}\mathrm{SO2} \\
\text { (mil ton) }\end{array}$ & & \\
\hline 1.627 & 2.546 & 142 & 1 & 1,099 & 1,720 & 77 & 1 & 1.627 & 2.547 & 102 & 1 & 0.0401 & 0.0003 \\
\hline 37 & 127 & 413 & 3 & 25 & 71 & 185 & 2 & 37 & 97 & 228 & 2 & 2.3449 & 0.0191 \\
\hline 30 & 128 & . 27 & 0 & 20 & 64 & 11 & 0 & 30 & 84 & 13 & 0 & 0.1542 & 0.0003 \\
\hline 0 & 32 & 0 & 0 & 0 & 23 & 0 & 0 & 0 & 34 & 0 & 0 & 0.0000 & 0.0000 \\
\hline 0 & 78 & 0 & 0 & 0 & 53 & 0 & 0 & 0 & 78 & 0 & 0 & 0.0000 & 0.0000 \\
\hline 406 & 658 & 135 & 1 & 274 & 445 & 73 & $i$ & 406 & 658 & 97 & 1 & 0.1472 & 0.0012 \\
\hline 197 & 589 & 95 & 1 & 133 & 399 & 52 & 0 & 197 & 591 & 69 & 1 & 0.1163 & 0.0009 \\
\hline 115 & 158 & 0 & 0 & 78 & 107 & 0 & 0 & 115 & 158 & 0 & 0 & 0.0000 & 0.0000 \\
\hline 14 & 77 & 0 & 0 & 9 & 52 & 0 & 0 & 14 & 78 & 0 & 0 & 0.0000 & 0.0000 \\
\hline 49 & 273 & 76 & $i$ & 33 & 185 & 41 & 0 & 49 & 274 & 55 & 0 & 0.2016 & 0.0016 \\
\hline 22 & 166 & 1296 & 10 & 15 & 93 & 579 & 5 & 22 & 128 & 707 & 6 & 5.6245 & 0.0456 \\
\hline 8 & 165 & 108 & 0 & 6 & 89 & 47 & 0 & $\theta$ & 119 & 56 & 0 & 0.4697 & 0.0005 \\
\hline 6 & 21 & 180 & $i$ & 4 & 15 & 101 & 1 & 6 & 22 & 136 & 1 & 6.0608 & 0.0494 \\
\hline 42 & 722 & 400 & 3 & 28 & 490 & 217 & 2 & 42 & 727 & 290 & 2 & 0.3991 & 0.0030 \\
\hline 7 & 293 & 417 & 3 & 2 & 196 & 223 & 2 & 3 & 290 & 297 & 2 & 1.0223 & 0.0083 \\
\hline 0 & 365 & 311 & 3 & 0 & 256 & 175 & 1 & 0 & 385 & 237 & 2 & 0.6150 & 0.0049 \\
\hline 37 & 173 & 34 & 0 & 25 & 118 & 18 & 0 & 37 & 176 & 25 & 0 & 0.1398 & 0.0011 \\
\hline 204 & 389 & 47 & 0 & 138 & 334 & 33 & 0 & 204 & 534 & 47 & 0 & 0.0877 & 0.0007 \\
\hline 54 & 108 & 13 & 0 & 36 & 73 & 7 & 0 & 54 & 109 & 10 & 0 & 0.0877 & 0.0007 \\
\hline 80 & 186 & 23 & 0 & 54 & 128 & 12 & 0 & 80 & 191 & 17 & 0 & 0.0877 & 0.0007 \\
\hline 91 & 145 & 18 & 0 & 50 & 83 & 8 & 0 & 68 & 114 & 10 & 0 & 0.0877 & 0.0007 \\
\hline 0 & 17 & 0 & 0 & 0 & 11 & 0 & 0 & 0 & 17 & 0 & 0 & 0.0000 & 0.0000 \\
\hline 85 & 90 & 0 & 0 & 57 & 61 & 0 & 0 & 85 & 90 & 0 & 0 & 0.0000 & 0.0000 \\
\hline 34 & 81 & 0 & 0 & 23 & 55 & 0 & 0 & 34 & 82 & 0 & 0 & 0.0000 & 0.0000 \\
\hline 798 & 798 & 20 & 0 & 539 & 539 & 11 & 0 & 798 & 798 & 14 & 0 & 0.0180 & 0.0001 \\
\hline 162 & 343 & 143 & 1 & 109 & 231 & 77 & 1 & 162 & 342 & 102 & 1 & 0.2996 & 0.0021 \\
\hline 113 & 406 & 37 & 0 & 76 & 276 & 20 & 0 & 113 & 409 & 27 & 0 & 0.0663 & 0.0005 \\
\hline 92 & 92 & 9 & 0 & 62 & 62 & 5 & 0 & 92 & 92 & 6 & 0 & 0.0663 & 0.0005 \\
\hline 54 & 91 & 10 & 0 & 37 & 62 & 6 & 0 & 54 & 91 & 7 & 0 & 0.0817 & 0.0006 \\
\hline 287 & 357 & 31 & 0 & 194 & 241 & 17 & 0 & 287 & 357 & 22 & 0 & 0.0622 & 0.0005 \\
\hline 607 & 727 & 63 & 0 & 410 & 491 & 34 & 0 & 607 & 727 & 45 & 0 & 0.0622 & 0.0005 \\
\hline 7 & 188 & 16 & 0 & 4 & 128 & 9 & 0 & 7 & 191 & 12 & 0 & 0.0622 & 0.0005 \\
\hline 249 & 249 & 22 & 0 & 168 & 168 & 12 & 0 & 249 & 249 & 15 & 0 & 0.0622 & 0.0005 \\
\hline 5.514 & 10,840 & 4,086 & 32 & 3.712 & 7,323 & 2,048 & 16 & 5,488 & 10,840 & 2,646 & 21 & & \\
\hline
\end{tabular}

Final Demand and Gross Output in billions of 1990 Yuans

Final Demand(GDP) Growth Rate $2000-2010 \quad 3.99 \%$

CO2 Emlssion Reduction

2000-2010 $\quad 35.23 \%$ 
1 Agriculture

3 Cruda pettoleum \& natural gas prod

4 Matal ore mining

5 Other mining

8 Food manufacturing

8 Manulaclure of apparel

9 Sawmills and manufaclure of furniture

10 Manufacture of paper and odue materia

11 Electicity steam and hot wator prod

12 Petroleum rofineries

13 Coking. manufacture of gas \& coal

14 Chemical industries

15 Manufacture of building materiais

16 Primary motal manutacturing

18 Manufacture of metal products

19 Manufacture of transport equipment

20 Manutacture of electric machinery

21 Manulacture of electronics equip

22 Manufacture of instruments

23 Maintenance and repair of machinery

24 Industries not elsewhere classified

25 Construction

26 Freight transport and communication

28 Restaurants

30 Public utilities and services to house

31 Cullural, education and health services

2 Finance and insurance

33 Public administration

Tolal

Final Demand and Gross Output in billions of 1990 Yuans

Final Demand(GOP) Growth Rate 2010-2025

\begin{tabular}{|c|c|c|c|c|c|c|c|}
\hline $\begin{array}{c}\text { Basolino } \\
2025\end{array}$ & & & & $\begin{array}{l}\text { DLP } \\
2010\end{array}$ & & & \\
\hline $\begin{array}{c}\text { Final } \\
\text { Domand }\end{array}$ & $\begin{array}{l}\text { Gross } \\
\text { Output }\end{array}$ & $\begin{array}{c}\text { CO2 } \\
\text { (mil ton) }\end{array}$ & $\begin{array}{c}\mathrm{SO}^{\mathrm{SO}} \\
\text { (mil ton) }\end{array}$ & $\begin{array}{c}\text { Final } \\
\text { Oemand }\end{array}$ & $\begin{array}{l}\text { Gross } \\
\text { Oulput }\end{array}$ & $\underset{\text { (mil ton) }}{\mathrm{CO} 2}$ & $\underset{\text { (mil ton) }}{\mathrm{SO}}$ \\
\hline
\end{tabular}

DLP

$\mathrm{CO} 2$

SO2

Final Gross $\mathrm{CO2} \quad \mathrm{SO2}$ COEFFICIENT COEFFICIENT

\begin{tabular}{|c|c|c|c|c|c|c|c|c|c|c|c|c|c|}
\hline 2.534 & 3.966 & 221 & 2 & 1,627 & 2,547 & 102 & 1 & 2.534 & 3,968 & 143 & 1 & 0.0361 & 0.0003 \\
\hline 58 & 198 & 644 & 5 & 37 & 97 & 228 & 2 & 58 & 141 & 297 & 2 & 2.1104 & 0.0172 \\
\hline 46 & 199 & 43 & 0 & 30 & 84 & 13 & 0 & 46 & 117 & 16 & 0 & 0.1387 & 0.0003 \\
\hline 0 & 50 & 0 & 0 & 0 & 34 & 0 & 0 & 0 & 54 & 0 & 0 & 0.0000 & 0.0000 \\
\hline 1 & 122 & 0 & 0 & 0 & 78 & 0 & 0 & 1 & 122 & 0 & 0 & 0.0000 & 0.0000 \\
\hline 632 & 1.025 & 210 & 2 & 406 & 658 & 97 & 1 & 632 & 1,026 & 136 & 1 & 0.1325 & 0.0011 \\
\hline 307 & 917 & 148 & 1 & 197 & 591 & 69 & 1 & 307 & 922 & 96 & 1 & 0.1046 & 0.0008 \\
\hline 180 & 246 & 0 & 0 & 115 & 158 & 0 & 0 & 180 & 247 & 0 & 0 & 0.0000 & 0.0000 \\
\hline 22 & 119 & 0 & 0 & 14 & 78 & 0 & 0 & 22 & 122 & 0 & 0 & 0.0000 & 0.0000 \\
\hline 77 & 426 & 119 & 1 & 49 & 274 & 55 & 0 & $\pi$ & 428 & 78 & 1 & 0.1814 & 0.0015 \\
\hline 35 & 258 & 2019 & 16 & 22 & 126 & 707 & 6 & 35 & 180 & 911 & 7 & 5.0621 & 0.0410 \\
\hline 13 & 257 & 168 & 0 & 8 & 119 & 56 & 0 & 13 & 168 & 71 & o & 0.4227 & 0.0005 \\
\hline 9 & $\mathbf{3 3}$ & 281 & 2 & 6 & 22 & 136 & 1 & 9 & 35 & 192 & 2 & 5.4547 & 0.0445 \\
\hline 66 & 1.125 & 624 & 5 & 42 & 727 & 290 & 2 & 66 & 1.135 & 408 & 3 & 0.3592 & 0.0027 \\
\hline 11 & 457 & 649 & 5 & 3 & 290 & 297 & 2 & 5 & 452 & 416 & 3 & 0.9201 & 0.0074 \\
\hline 0 & 568 & 485 & 4 & 0 & 385 & 237 & 2 & 0 & 607 & 336 & 3 & 0.5535 & 0.0044 \\
\hline 58 & 270 & 52 & 0 & 37 & 176 & 25 & 0 & 58 & 275 & 35 & 0 & 0.1258 & 0.0010 \\
\hline 318 & 605 & 74 & 1 & 204 & 534 & 47 & 0 & 318 & 886 & 70 & 1 & 0.0789 & 0.0006 \\
\hline 83 & 169 & 21 & 0 & 54 & 109 & 10 & 0 & 83 & 170 & 13 & 0 & 0.0789 & 0.0006 \\
\hline 125 & 290 & 35 & 0 & 80 & 191 & 17 & 0 & 125 & 299 & 24 & 0 & 0.0789 & 0.0006 \\
\hline 141 & 226 & 28 & 0 & 68 & 114 & 10 & 0 & 96 & 165 & 13 & 0 & 0.0789 & 0.0006 \\
\hline 0 & 26 & 0 & 0 & 0 & 17 & 0 & 0 & 0 & 27 & 0 & 0 & 0.0000 & 0.0000 \\
\hline 132 & 141 & 0 & 0 & 85 & 90 & 0 & 0 & 132 & 141 & 0 & 0 & 0.0000 & 0.0000 \\
\hline 54 & 126 & 0 & 0 & 34 & 82 & 0 & 0 & 54 & 127 & 0 & 0 & 0.0000 & 0.0000 \\
\hline 1.244 & 1.244 & 31 & 0 & 798 & 798 & 14 & 0 & 1,244 & 1.244 & 20 & 0 & 0.0162 & 0.0001 \\
\hline 252 & 534 & 222 & 2 & 162 & 342 & 102 & 1 & 252 & 533 & 144 & 1 & 0.2697 & 0.0019 \\
\hline 176 & 633 & 58 & 0 & 113 & 409 & 27 & 0 & 176 & 638 & 38 & 0 & 0.0597 & 0.0005 \\
\hline 144 & 144 & 13 & 0 & 92 & 92 & 6 & 0 & 144 & 144 & 9 & 0 & 0.0597 & 0.0005 \\
\hline 85 & 142 & 16 & 0 & 54 & 91 & 7 & 0 & 85 & 142 & 10 & 0 & 0.0736 & 0.0006 \\
\hline 447 & 556 & 48 & 0 & 287 & 357 & 22 & 0 & 447 & 557 & 31 & 0 & 0.0560 & 0.0004 \\
\hline 946 & 1,133 & 98 & 1 & 607 & 727 & 45 & 0 & 946 & 1,133 & 63 & 0 & 0.0560 & 0.0004 \\
\hline 10 & 293 & 25 & 0 & 7 & 191 & 12 & 0 & 10 & 298 & 17 & 0 & 0.0560 & 0.0004 \\
\hline 388 & 388 & 34 & 0 & 249 & 249 & 15 & 0 & 388 & 388 & 22 & 0 & 0.0560 & 0.0004 \\
\hline
\end{tabular}




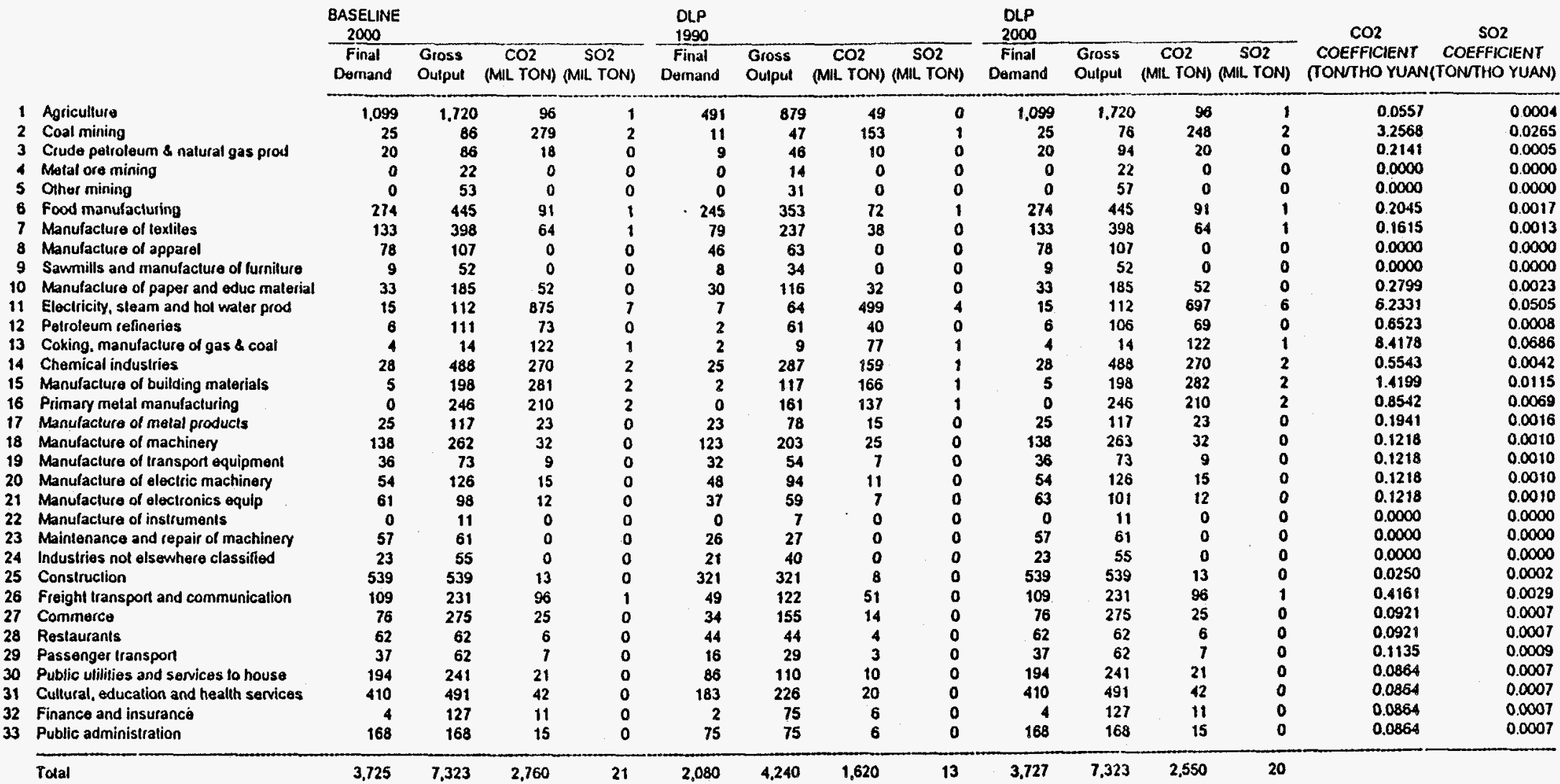

Final Demand and Gross Oulput in billions of 1990 Yuans 


\begin{tabular}{|c|c|c|c|c|c|c|c|c|c|c|c|c|c|c|c|}
\hline & & $\begin{array}{l}\text { BASELINE } \\
2000 \\
\end{array}$ & & & & $\begin{array}{r}\text { DLP } \\
+1990 \\
\end{array}$ & & & & $\begin{array}{r}\text { DLP } \\
2000 \\
\end{array}$ & & & & $\operatorname{coz}$ & SO2 \\
\hline & & $\begin{array}{l}\text { Final } \\
\text { Demand }\end{array}$ & $\begin{array}{l}\text { Gross } \\
\text { Oulput }\end{array}$ & $\begin{array}{c}\text { CO2 } \\
\text { (MIL TON) }\end{array}$ & $\begin{array}{l}\text { SO2 } \\
\text { (MIL. TON) }\end{array}$ & $\begin{array}{l}\text { Final } \\
\text { Dornand }\end{array}$ & $\begin{array}{l}\text { Gloss } \\
\text { Oulpulf }\end{array}$ & $\begin{array}{c}\mathrm{CO2} \\
\text { MUL. TON) }\end{array}$ & $\begin{array}{c}\text { SO2 } \\
\text { (MLILTON) }\end{array}$ & $\begin{array}{c}\text { Final } \\
\text { Demand }\end{array}$ & $\begin{array}{l}\text { Gross } \\
\text { Ouiput }\end{array}$ & $\begin{array}{c}\mathrm{CO} 2 \\
\text { (MiL. TON) }\end{array}$ & $\begin{array}{c}\text { SO2 } \\
\text { MHL TON) }\end{array}$ & $\begin{array}{l}\text { COEFFICIENT } \\
\text { (TONTHO YUANG }\end{array}$ & $\begin{array}{l}\text { COEFFICIENT } \\
\text { (TONTTHO YUAN) }\end{array}$ \\
\hline 1 & Agriculture & 1.099 & 1,720 & 96 & 1 & $49 i$ & 879 & 49 & 0 & 1,099 & 1.769 & 99 & 1 & 0.0557 & 0.0004 \\
\hline 2 & Coal mining & 25 & 86 & 279 & 2 & 11 & 47 & 153 & 1 & 25 & 78 & 255 & 2 & 3.2568 & 0.0265 \\
\hline 3 & Crude pelroleum \& natural gas prod & 20 & 86 & 18 & 0 & 9 & 46 & 10 & 0 & 20 & 97 & 21 & 0 & 0.2141 & 0.0005 \\
\hline 4 & Molal ore mining & 0 & 22 & $\mathbf{0}$ & 0 & 0 & 14 & 0 & o & 0 & 23 & $\mathbf{0}$ & 0 & 0.0000 & 0.0000 \\
\hline 5 & Other mining & 0 & 53 & 0 & 0 & 0 & 31 & 0 & $\mathbf{0}$ & 0 & 59 & $\mathbf{0}$ & o & 0.0000 & 0.0000 \\
\hline 6 & Food manutacturing & 274 & 445 & 91 & 1 & 245 & 353 & 72 & 1 & 274 & 457 & 93 & 1 & 0.2045 & 0.0017 \\
\hline 7 & Manufaclure of textites & 133 & 398 & 64 & 1 & 79 & 237 & 38 & 0 & 133 & 409 & 66 & 1 & 0.1615 & 0.0013 \\
\hline 8 & Manufacture of appatel & 78 & 107 & 0 & 0 & 46 & 63 & 0 & 0 & 78 & 110 & 0 & 0 & 0.0000 & 0.0000 \\
\hline 9 & Sawmills and manufacture of furniture & 9 & 52 & 0 & 0 & 8 & 34 & 0 & 0 & 9 & 53 & 0 & 0 & 0.0000 & 0.0000 \\
\hline 10 & Manufaclure of paper and educ malerial & 33 & 185 & 52 & 0 & 30 & 116 & 32 & 0 & 33 & 190 & 53 & 0 & 0.2799 & 0.0023 \\
\hline 11 & Eloctricity, sleam and hot water prods & 15 & 112 & 875 & 7 & 7 & 64 & 499 & 4 & 15 & 115 & $m 17$ & 6 & 6.2331 & 0.0505 \\
\hline 12 & Petroleum refinesies & 6 & 111 & 73 & 0 & 2 & 61 & 40 & 0 & 6 & 109 & 71 & 0 & 0.6523 & 0.0008 \\
\hline 13 & Coking. manufaclure of gas $\&$ coal & 4 & 14 & 122 & 1 & 2 & 2 & 77 & 1 & 4 & 15 & 125 & 1 & 8.4178 & 0.0686 \\
\hline 14 & Chemical industries & 28 & 488 & 270 & 2 & 25 & 287 & 159 & 1 & 28 & 502 & 278 & 2 & 0.5543 & 0.0042 \\
\hline 15 & Manulacture of building malerials & $\mathbf{s}$ & 198 & 281 & 2 & 2 & 117 & 866 & 1 & $\mathbf{s}$ & 204 & 290 & 2 & 1.4199 & 0.0115 \\
\hline 16 & Primary metal manufacluring & 0 & 246 & 210 & 2. & 0 & 161 & 137 & 1 & 0 & 253 & 216 & 2 & 0.8542 & 0.0069 \\
\hline 17 & Manulacture of metal products & 25 & 117 & 23 & 0 & 23 & 78 & 15 & 0 & 25 & 120 & 23 & 0 & $0.19+1$ & 0.0016 \\
\hline 18 & Manufaclure of machinery & 130 & 262 & 32 & 0 & 123 & 203 & 25 & 0 & 138 & 270 & 33 & 0 & 0.1218 & 0.0010 \\
\hline 19 & Manulacture of trainsport equipment & 36 & 73 & 9 & 0 & 32 & 54 & 7 & 0 & 36 & 75 & 9 & $\mathbf{0}$ & 0.1218 & 0.0010 \\
\hline 20 & Manulacture of electric machinery & 54 & 126 & 15 & 0 & 48 & 94 & 11 & 0 & 54 & 129 & 16 & $\mathbf{0}$ & 0.1218 & 0.0010 \\
\hline 21 & Manulacture of electronics equip & 61 & 98 & 12 & 0 & 37 & 59 & 7 & 0 & 63 & 104 & 13 & 0 & 0.1218 & 0.0010 \\
\hline 22 & Manufacture of instrumenls & 0 & 11 & 0 & 0 & 0 & 7 & 0 & 0 & 0 & 12 & 0 & 0 & 0.0000 & 0.0000 \\
\hline 23 & Mointenance and repair of machinery & 57 & 61 & 0 & 0 & 26 & 27 & 0 & 0 & 57 & 63 & 0 & 0 & 0.0000 & 0.0000 \\
\hline 24 & Industries nol elsewhere classified & 23 & 55 & 0 & 0 & 21 & 40 & 0 & 0 & 23 & 56 & 0 & 0 & 0.0000 & 0.0000 \\
\hline 25 & Construction & 539 & 539 & 13 & 0 & 321 & 321 & $\mathbf{B}$ & 0 & 539 & 555 & 14 & 0 & 0.0250 & 0.0002 \\
\hline 26 & Freight transport and communication & 109 & 231 & 96 & 1 & 49 & 122 & 51 & 0 & 109 & 238 & 99 & 1 & 0.4161 & 0.0029 \\
\hline 27 & Commerca & 76 & 275 & 25 & 0 & 34 & 155 & 14 & 0 & 76 & 282 & 26 & 0 & 0.0921 & 0.0007 \\
\hline 28 & Restaurants & 62 & 62 & 6 & 0 & 44 & 44 & 4 & 0 & 62 & 64 & 6 & 0 & 0.0921 & 0.0007 \\
\hline 29 & Passenger transport & 37 & 62 & 7 & 0 & 16 & 29 & 3 & 0 & 37 & 63 & 7 & 0 & 0.1135 & 0.0009 \\
\hline 30 & Public utitities and services to house & 194 & 241 & 21 & 0 & 86 & $\$ 10$ & 10 & 0 & 194 & 248 & 21 & 0 & 0.0864 & 0.0007 \\
\hline 31 & Cultural, oducation and health senvicos & 410 & 499 & 42 & 0 & 183 & 226 & 20 & 0 & 410 & 505 & 44 & 0 & 0.0864 & 0.0007 \\
\hline 32 & Finance and insurance & 4 & 127 & 11 & 0 & 2 & 75 & 6 & 0 & 4 & 131 & 11 & 0 & 0.0864 & 0.0007 \\
\hline 33 & Public administration & 168 & 168 & 15 & 0 & 75 & 75 & 6 & 0 & 168 & 173 & 15 & 0 & 0.0864 & 0.0007 \\
\hline
\end{tabular}

Final Demand and Gross Output in billions of 1990 Yuans 


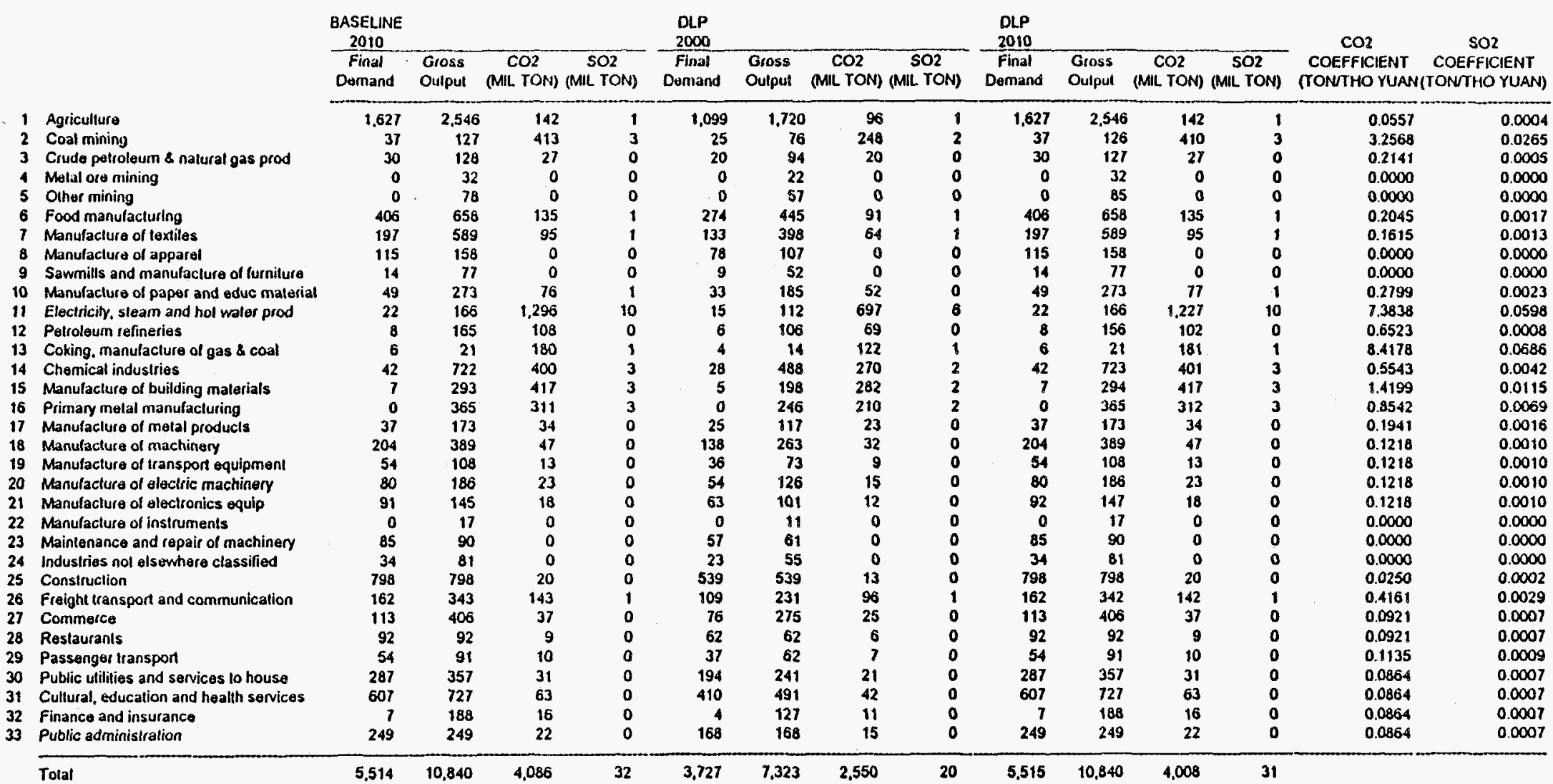

Final Demand and Gross Output in billions of 1990 Yuans

Final Demand(GDP) Growth Rate

$2000-2010 \quad 4.00 \%$
CO2 Emission Reduction

$2000-2010 \quad 1.89 \%$ 


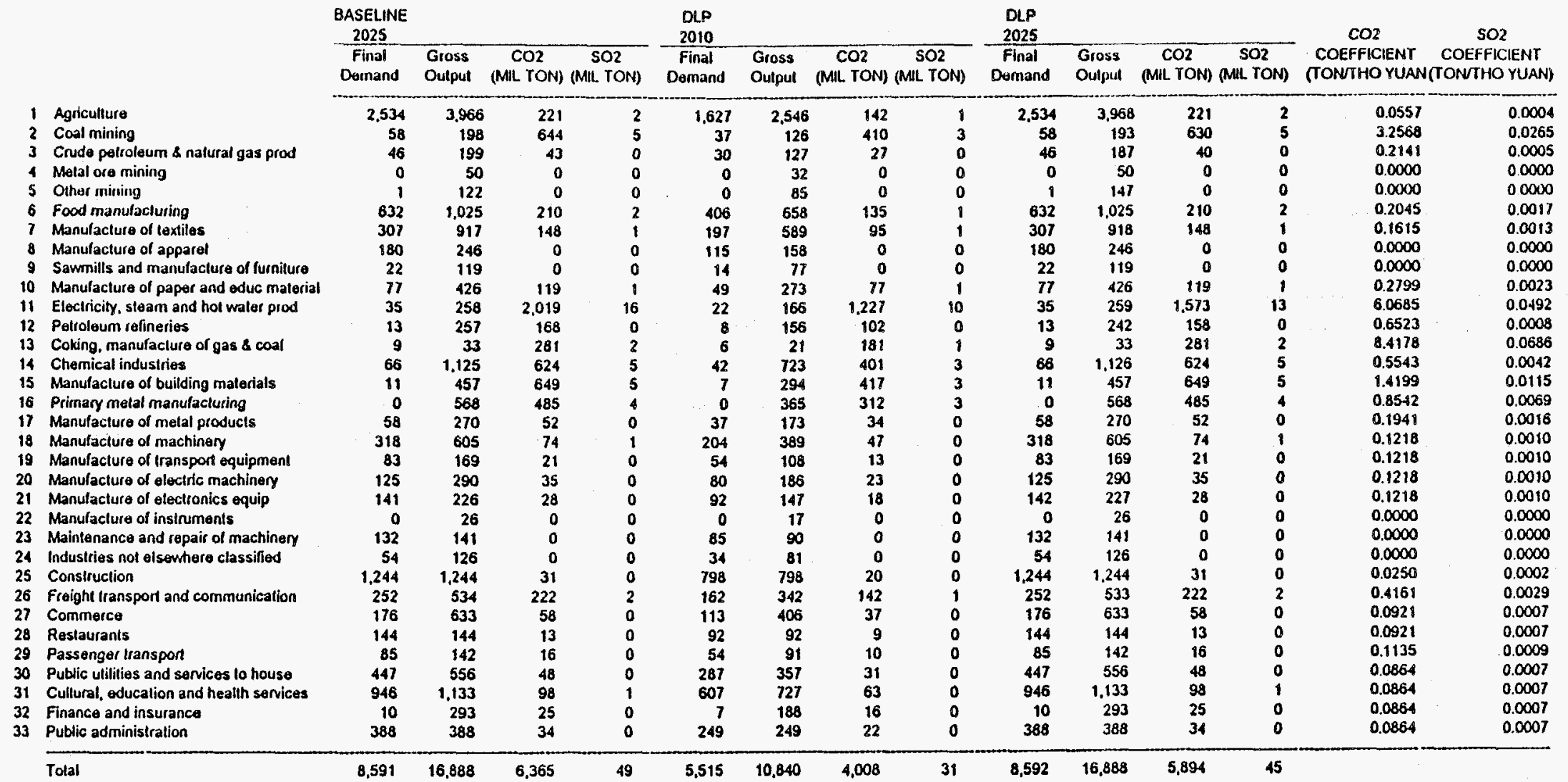

Final Demand and Gross Oulput in billions of 1990 Yuans

Finat Demand(GDP) Growth Rato

$2010-2025$ 300\%
$\mathrm{CO} 2$ Emission Reduction

2010-2025 7.39\% 


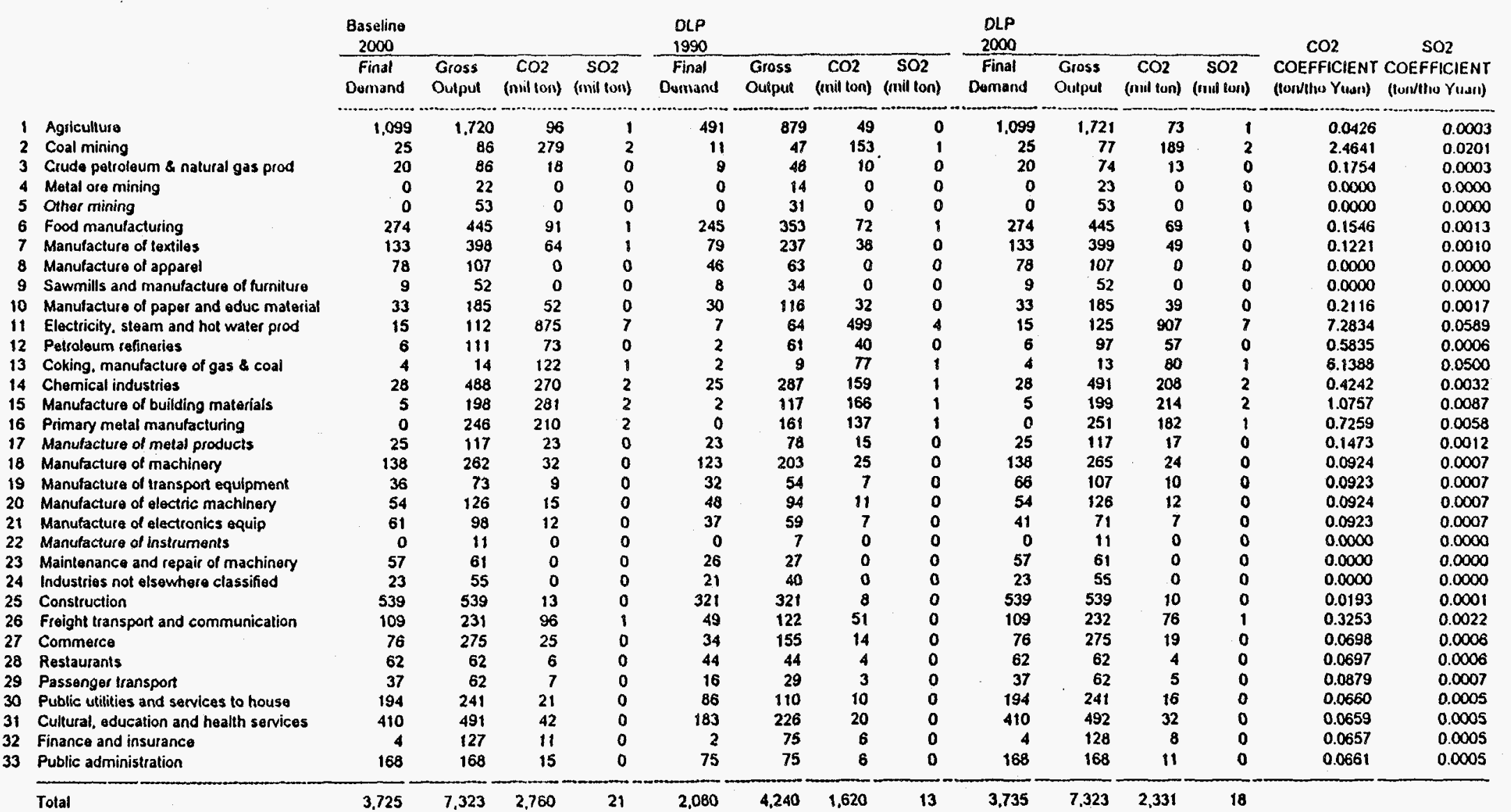

Final Demand and Gross Output in billions of 1990 Yuans
Final Demand(GDP) Growth Rate
$1990-2000$
$6.03 \%$
CO2 Emission Roduction 
1 Agriculture

2 Coal mining

Crude poltoleum \& natural gas prod

Metal ore mining

Other mining

Food manulacturing

Manufacture of textilos

Manufacture of apparel

9 Sawmills and manufacture of turniture

10 Manufacture of paper and educ material

11 Electricity, steam and hos water prod

12 Petrolaum refineries

13 Coking. manufacture of gas \& coal

14 Chemical industries

15 Manutacture of building materials

16 Primary metal manufacturing

17 Manufacture of metal product

18 Manufacture of machinery

19 Manufacture of transport equipment

Manufacture of electric machiner

22 Manufacturs of instruments

23 Maintenance and fepair of machinery

24 industries not olsowhere classified

25 Construction

26 Freight transport and communication

27 Commerce

29. Restaurants

30 Public utilities and services to house

31 Cultural, oducation and health services

Total 3,725

\begin{tabular}{|c|c|c|c|c|c|c|c|c|c|c|c|c|c|}
\hline \multirow{2}{*}{$\begin{array}{c}\begin{array}{c}\text { Baseline } \\
2000\end{array} \\
\text { Final } \\
\text { Demand }\end{array}$} & \multirow[b]{2}{*}{$\begin{array}{l}\text { Gross } \\
\text { Output }\end{array}$} & \multirow[b]{2}{*}{$\begin{array}{c}\mathrm{CO} 2 \\
\text { (mil ton) }\end{array}$} & \multirow[b]{2}{*}{$\begin{array}{c}\mathrm{SO} 2 \\
\text { (mil ion) }\end{array}$} & & \multicolumn{4}{|l|}{$\begin{array}{r}\text { OLP } \\
2000 \\
\end{array}$} & \multirow{2}{*}{$\begin{array}{c}\text { COZ } \\
\text { COEFFICIENT } \\
\text { (low/tho Yuan) }\end{array}$} & \multirow{2}{*}{$\begin{array}{c}\mathrm{SO2} \\
\text { COEFFICIENT } \\
\text { (ton/tho Yuan) }\end{array}$} \\
\hline & & & & $\begin{array}{c}\text { Final } \\
\text { Demand }\end{array}$ & $\begin{array}{l}\text { Gross } \\
\text { Output }\end{array}$ & $\begin{array}{c}\mathrm{CO} 2 \\
\text { (mil ton) }\end{array}$ & $\begin{array}{c}\mathrm{SO}^{2} \\
\text { (mil ton) }\end{array}$ & $\begin{array}{c}\text { Final } \\
\text { Domand }\end{array}$ & $\begin{array}{l}\text { Gross } \\
\text { Output }\end{array}$ & $\underset{\text { (mil ton) }}{\mathrm{CO} 2}$ & $\begin{array}{c}\mathrm{SO2} \\
\text { (mil ton) }\end{array}$ & & \\
\hline 1,099 & 1.720 & 96 & 1 & 491 & 879 & 49 & 0 & 1.097 & 1.936 & 82 & 1 & 0.0426 & 0.0003 \\
\hline 25 & 86 & 279 & 2 & 11 & 47 & 153 & 1 & 25 & 86 & 212 & 2 & 2.4641 & 0.0201 \\
\hline 20 & 86 & 18 & 0 & 9 & 46 & 10 & 0 & 20 & 84 & 15 & 0 & 0.1754 & 0.0003 \\
\hline 0 & 22 & 0 & 0 & 0 & 14 & 0 & 0 & 0 & 25 & 0 & 0 & 0.0000 & 0.0000 \\
\hline 0 & 53 & 0 & 0 & 0 & 31 & 0 & 0 & 0 & 60 & 0 & 0 & 0.0000 & 0.0000 \\
\hline 274 & 445 & 91 & 1 & 245 & 353 & 72 & 1 & 273 & 500 & $\pi 7$ & 1 & 0.1546 & 0.0013 \\
\hline 133 & 398 & 64 & 1 & 79 & 237 & 38 & 0 & 133 & 449 & 55 & 0 & 0.1221 & 0.0010 \\
\hline 78 & 107 & 0 & 0 & 46 & 63 & 0 & 0 & 78 & 120 & 0 & 0 & 0.0000 & 0.0000 \\
\hline 9 & 52 & 0 & 0 & 8 & 34 & 0 & 0 & 9 & 59 & 0 & 0 & 0.0000 & 0.0000 \\
\hline 33 & 185 & 52 & 0 & 30 & $\$ 16$ & 32 & 0 & 33 & 208 & 44 & 0 & 0.2116 & 0.0017 \\
\hline 15 & 112 & 875 & 7 & 7 & 64 & 499 & 4 & 15 & 140 & 1,020 & 8 & 7.2834 & 0.0589 \\
\hline 6 & 111 & 73 & 0 & 2 & 61 & 40 & 0 & 6 & 109 & 64 & 0 & 0.5835 & 0.0006 \\
\hline 4 & 14 & 122 & $i$ & 2 & 9 & 77 & 1 & 4 & 15 & 90 & 1 & 6.1380 & 0.0500 \\
\hline 28 & 488 & 270 & 2 & 25 & 287 & 159 & 1 & 28 & 552 & 234 & 2 & 0.4242 & 0.0032 \\
\hline 5 & 198 & 281 & 2 & 2 & 117 & 166 & 1 & 5 & 223 & 240 & 2 & 8.0757 & 0.0087 \\
\hline 0 & 246 & 210 & 2 & 0 & 161 & 137 & $i$ & 0 & 282 & 205 & 2 & 0.7259 & 0.0058 \\
\hline 25 & 117 & 23 & 0 & 23 & 78 & 15 & 0 & 25 & 132 & 19 & 0 & 0.1473 & 0.0012 \\
\hline 138 & 262 & 32 & 0 & 123 & 203 & 25 & 0 & 138 & 298 & 28 & 0 & 0.0924 & 0.0007 \\
\hline 36 & 73 & 9 & 0 & 32 & S4 & 7 & 0 & 65 & 121 & 11 & 0 & 0.0923 & 0.0007 \\
\hline 54 & 126 & 15 & 0 & 48 & 94 & 11 & 0 & 54 & 141 & 13 & 0 & 0.0924 & 0.0007 \\
\hline 61 & 98 & 12 & 0 & 37 & 59 & 7 & 0 & 41 & 80 & 7 & 0 & 0.0923 & 0.0007 \\
\hline 0 & 11 & 0 & 0 & 0 & 7 & 0 & 0 & 0 & 13 & 0 & 0 & 0.0000 & 0.0000 \\
\hline 57 & 61 & 0 & 0 & 26 & 27 & 0 & 0 & 57 & 69 & 0 & 0 & 0.0000 & 0.0000 \\
\hline 23 & 55 & 0 & 0 & 21 & 40 & 0 & 0 & 23 & 62 & 0 & 0 & 0.0000 & 0.0000 \\
\hline 539 & 539 & 13 & 0 & 321 & 321 & 8 & 0 & 538 & 607 & 12 & 0 & 0.0193 & 0.0001 \\
\hline 109 & 231 & 96 & 1 & 49 & 122 & 51 & 0 & 109 & 261 & 85 & 1 & 0.3253 & 0.0022 \\
\hline 76 & 275 & 25 & 0 & 34 & 155 & 14 & 0 & 76 & 310 & 22 & 0 & 0.0698 & 0.0006 \\
\hline 62 & 62 & 6 & 0 & 44 & 44 & 4 & 0 & 62 & 70 & 5 & 0 & 0.0697 & 0.0006 \\
\hline 37 & 62 & 7 & 0 & 16 & 29 & 3 & 0 & 37 & 69 & 6 & 0 & 0.0879 & 0.0007 \\
\hline 194 & 241 & 21 & 0 & 86 & 110 & 10 & 0 & 193 & 272 & 18 & 0 & 0.0660 & 0.0005 \\
\hline 410 & 491 & 42 & 0 & 183 & 226 & 20 & 0 & 410 & 553 & 36 & 0 & 0.0659 & 0.0005 \\
\hline 4 & 127. & 11 & 0 & 2 & 75 & 6 & 0 & 4 & 144 & 9 & 0 & 0.0657 & 0.0005 \\
\hline 168 & 168 & 15 & 0 & 75 & 75 & 6 & 0 & 168 & 189 & 12 & 0 & 0.0661 & 0.0005 \\
\hline
\end{tabular}

Finat Demand and Gross Output in billions of 1990 Yuans

Finat Demand(GDR) Growth Rate 1990-2000

$\mathrm{CO} 2$ Emission Reduction

1990-2000 Reduction 


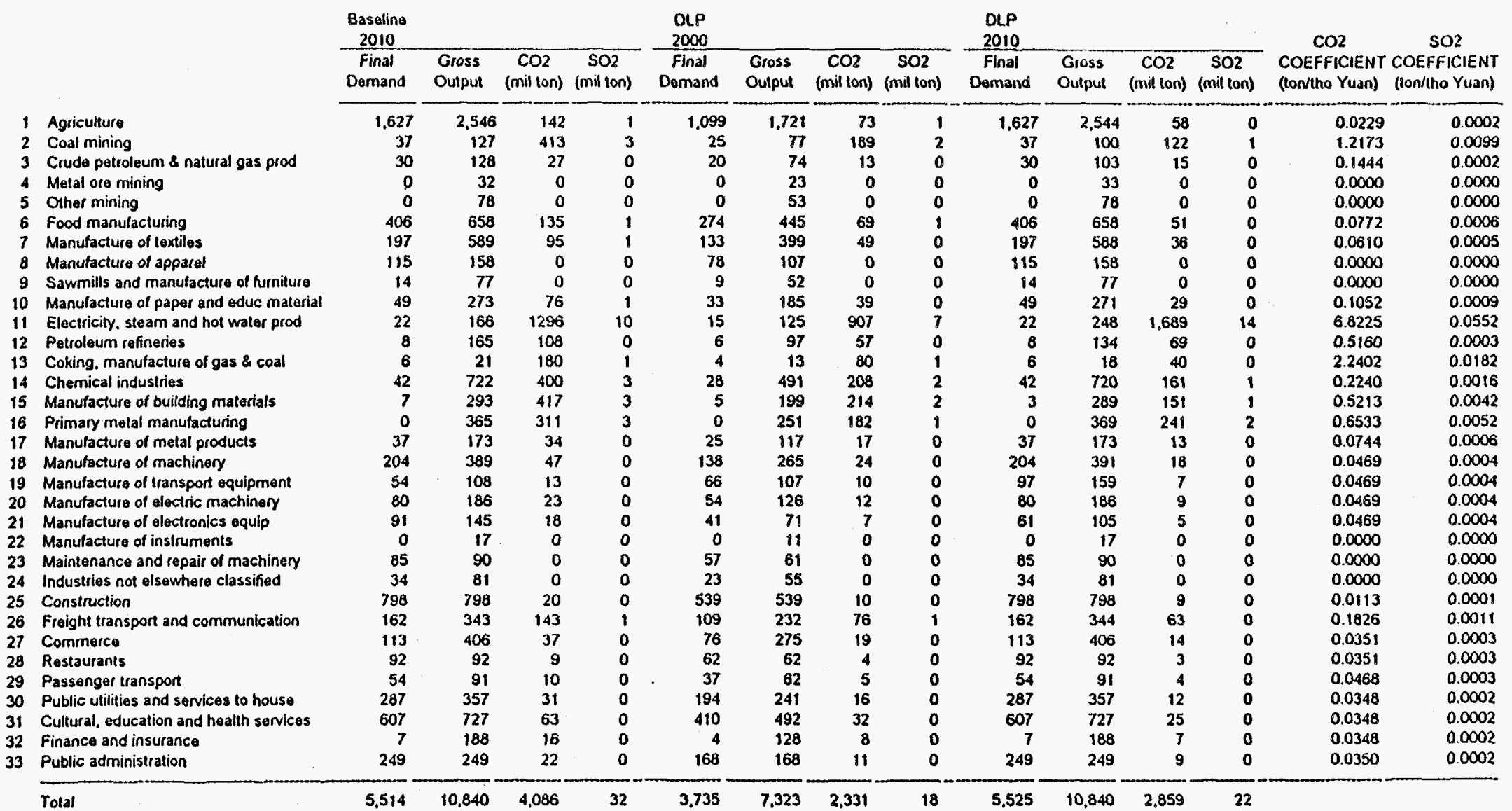

Final Demand and Gross Output in billions of 1990 Yuans

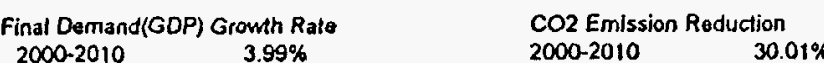




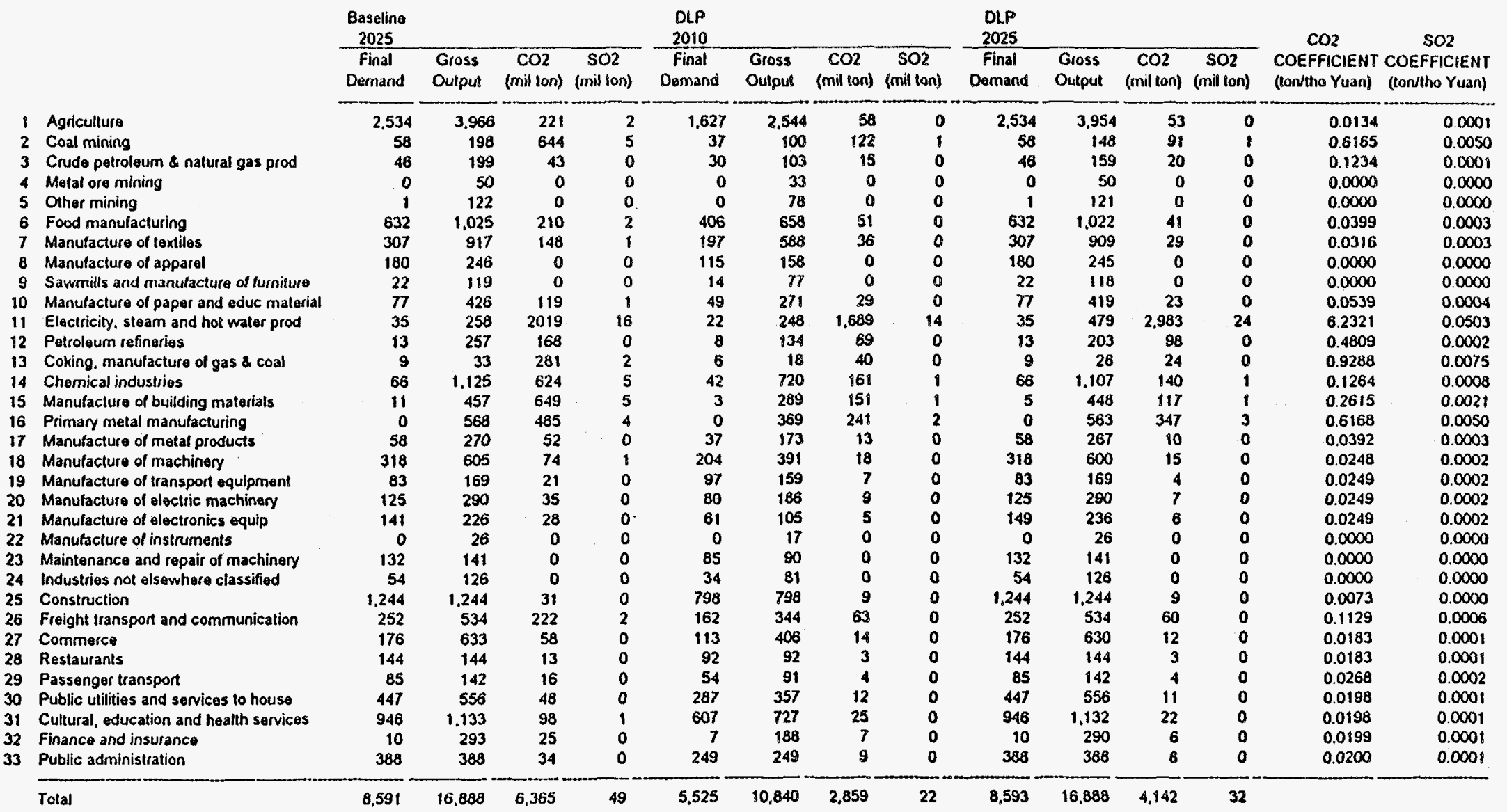

Final Demand and Gross Output in billions of 1990 Yuans

Final Demand(GDP) Growth Rate 2010-2025
CO2 Emission Reduction

2010.2025 $34.92 \%$ 


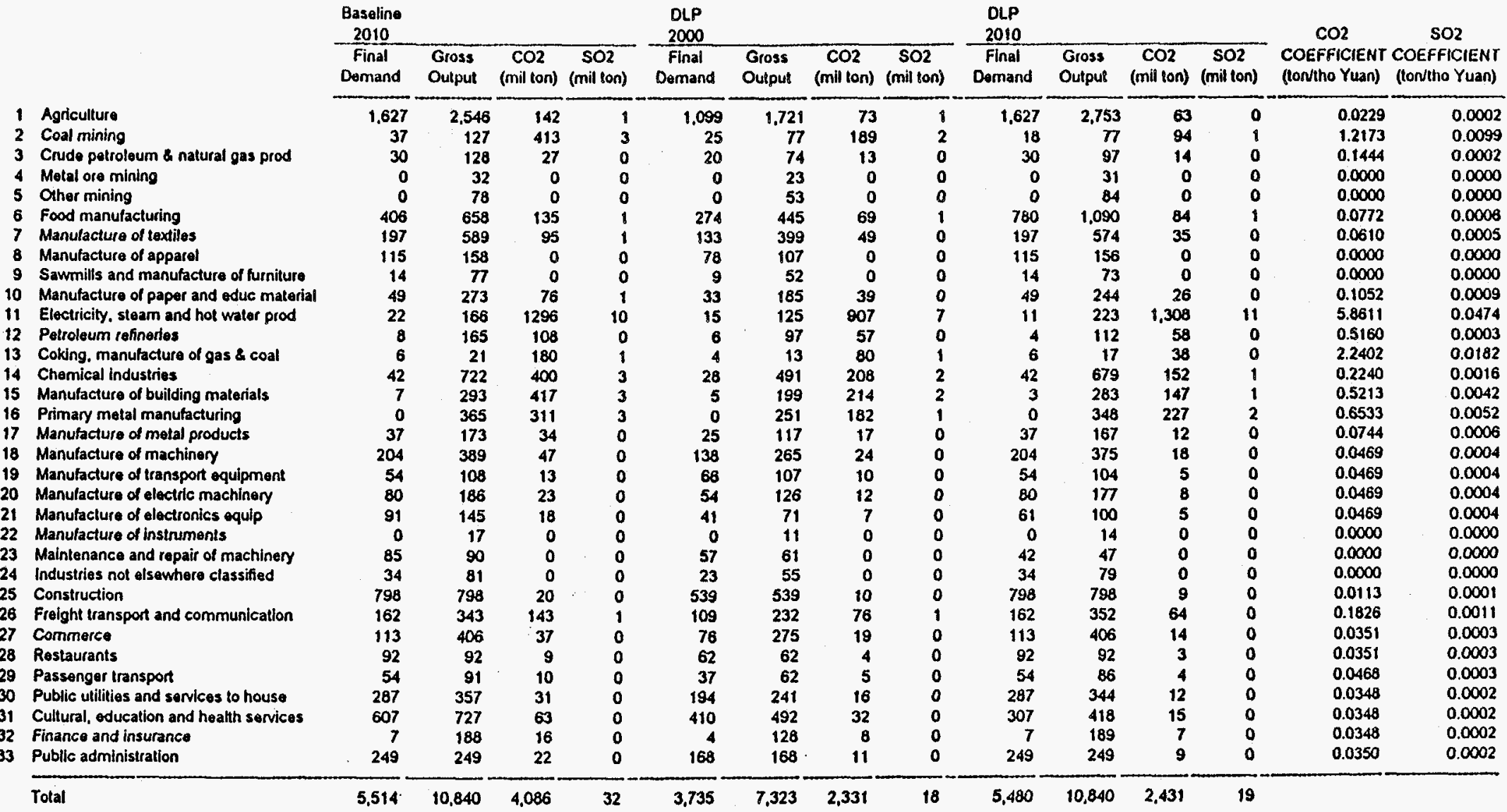

Final Demand and Gross Output in billions of 1990 Yuans
Final Demand(GDP) Growh Rate
02 Emission Reduction
2000-2010
$3.91 \%$
2000-2010
$40.50 \%$ 


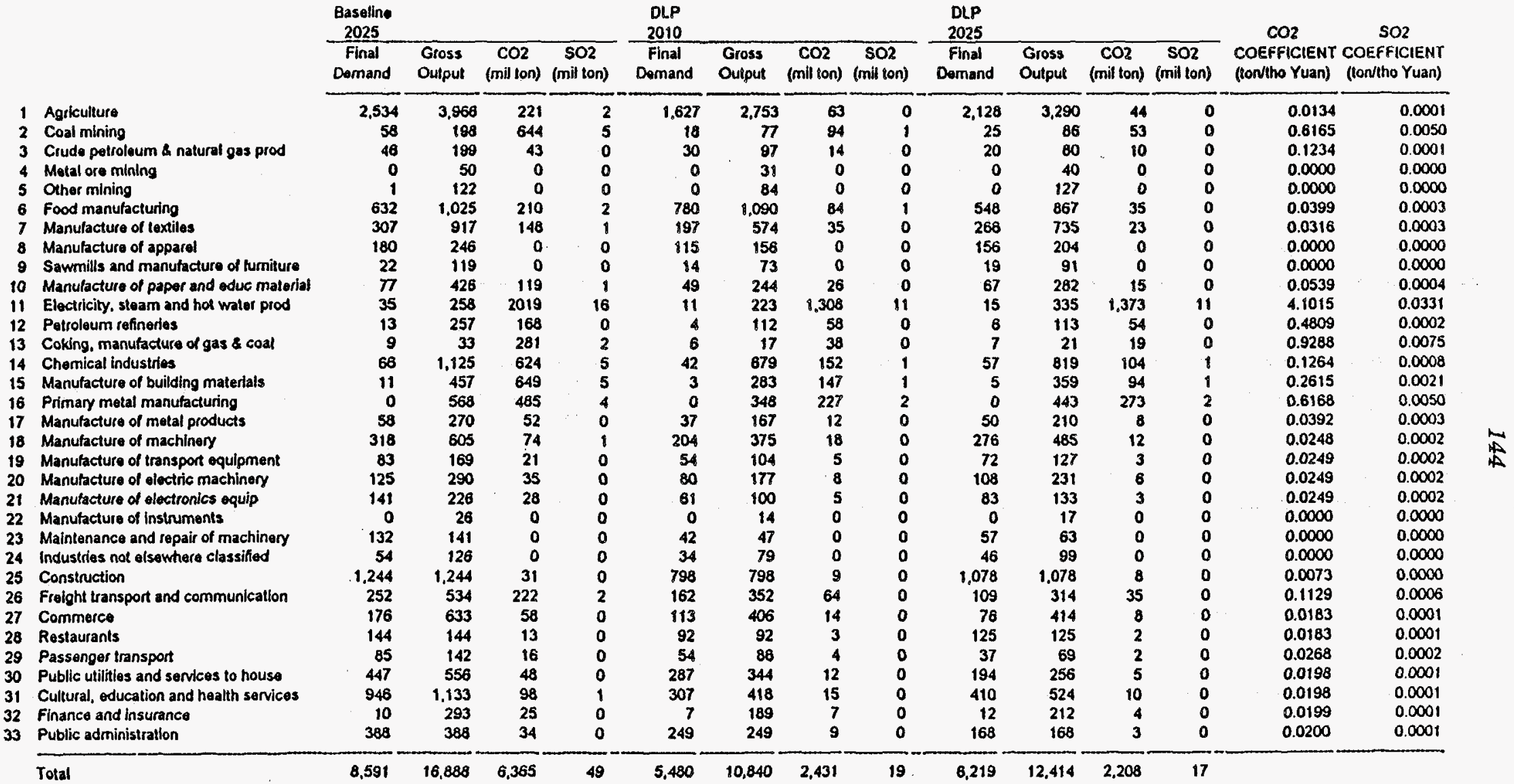

Final Demand and Gross Output in billions of 1990 Yuans

\begin{tabular}{|c|c|}
\hline Final Domand(GOP) Growth Rate & CO2 Emisslon Reduction \\
\hline
\end{tabular}


APPENDLX B:

INVESTMENT ANALYSIS SUMMMARY TABLES 
TABLE B1. CAPITAI COSTS FOR ELECTRICITY GENERATION AND TRANSMISSION (million dollars per MW installed capacity)

\begin{tabular}{lccc}
\hline & Generation & Transmission & Total \\
\hline Coal & $\$ 1.106$ & $\$ 0.221$ & $\$ 1.327$ \\
Oil & 0.790 & 0.221 & 1.011 \\
Natural Gas & 0.527 & 0.221 & 0.748 \\
Hydro & 1.216 & 0.221 & 1.437 \\
Nuclear & 1.520 & 0.221 & 1.741 \\
\hline
\end{tabular}

Sources: Dowlatabad, and Torman (1991); Kim (1993); and East-West Center (1994).

TABLE B2. CAPITAL COSTS FOR EXPLORATION AND PRODUCTION (dollars of investment per dollar of electricity sales)

\begin{tabular}{lccc}
\hline & Exploration & Production & Total \\
\hline Coal & $\$ 0.000$ & $\$ 0.092$ & $\$ 0.092$ \\
Oil & 0.198 & 0.422 & 0.620 \\
Natural Gas & 0.297 & 0.410 & 0.707 \\
Nuclear & 0.116 & 0.233 & 0.349 \\
\hline
\end{tabular}

Sources: Fraser and Seba (1993); Petroleum Economist; Energy Economist; and Mining Journal (various issues). 
TABLE B3. INCREMENTAL GROSS INVESTMENT IN ELECTRICITY GENERATION/TRANSMISSION-.INTERFUEL SUBSTITUTION STRATEGY, UPPER BOUND CASE ${ }^{a}$ (in billions of 1990 dollars)

\begin{tabular}{lrcc}
\hline Generation Type & $1990-2000$ & $2000-2010$ & $2010-2025$ \\
\hline Coal & $\$ 175.8$ & $\$ 195.8$ & $\$ 1,226.2$ \\
Oil & -12.2 & -27.5 & -88.1 \\
Natural Gas & 111.5 & 120.3 & 50.0 \\
Hydro & -12.0 & -30.0 & -79.2 \\
Nuclear & 5.8 & 59.6 & $1,925.2$ \\
\multicolumn{1}{c}{ Total } & $-\$ 82.8$ & $-\$ 73.6$ & $\$ 582.2$ \\
\hline
\end{tabular}

A negative figure implies savings with respect to the baseline.

TABLE B4. INCREMENTAL GROSS INVESTMENT IN ELECTRICITY GENERATION/TRANSMISSION--INTERFUEL SUBSTITUTION STRATEGY, UPPER BOUND CASE

(in billions of 1990 dollars)

\begin{tabular}{lccc}
\hline Generation Type & $\begin{array}{c}\text { Per Year } \\
1990-2000\end{array}$ & $\begin{array}{c}\text { Per Year } \\
2000-2010\end{array}$ & $\begin{array}{c}\text { Per Year } \\
2010-2025\end{array}$ \\
\hline Coal & $-\$ 17.6$ & $-\$ 19.6$ & $-\$ 81.7$ \\
Oil & -1.2 & -2.8 & -5.9 \\
Natural Gas & 11.2 & 12.0 & 3.3 \\
Hydro & -1.2 & -3.0 & -5.3 \\
Nuclear & .6 & 6.0 & 128.3 \\
\hline \multicolumn{1}{c}{ Total } & - & $-\$ 7.4$ & $\$ 38.8$ \\
\hline
\end{tabular}

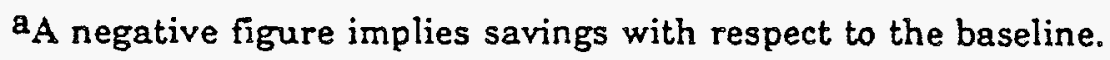


TABLE B5. INCREMENTAL GROSS INVESTMENT IN ELECTRICITY GENERATION/TRANSMISSION--TECHNOLOGICAL CHANGE STRATEGY, UPPER BOUND CASE ${ }^{a}$

(in billions of 1990 dollars)

\begin{tabular}{lrcc}
\hline Generation Type & $1990-2000$ & $2000-2010$ & $2010-2025$ \\
\hline Coal & $-\$ 44.0$ & $\$ 140.9$ & $\$ 238.3$ \\
Oil & -3.4 & 10.8 & 18.3 \\
Natural Gas & -.1 & .5 & .8 \\
Hydro & -13.0 & 42.2 & .9 \\
Nuclear & -.2 & .5 & .9 \\
$\quad$ Total & $-\$ 60.9$ & $\$ 194.9$ & $\$ 329.8$ \\
\hline
\end{tabular}

a A negative figure implies savings with respect to the baseline.

TABLE B6. INCREMENTAL GROSS INVESTMENT IN ELECTRICITY GENERATION/TRANSMISSION--TECHNOLOGICAL CHANGE STRATEGY, UPPER BOUND CASE ${ }^{2}$ (in billions of 1990 dollars)

\begin{tabular}{lccc}
\hline & $\begin{array}{c}\text { Per Year } \\
1990-2000\end{array}$ & $\begin{array}{c}\text { Per Year } \\
2000-2010\end{array}$ & $\begin{array}{c}\text { Per Year } \\
2010-2025\end{array}$ \\
\hline Coal & $-\$ 4.4$ & $\$ 14.1$ & $\$ 15.9$ \\
Oil & -.3 & 1.1 & 1.2 \\
Natural Gas & -.01 & .05 & .05 \\
Hydro & -1.3 & 4.2 & 4.8 \\
Nuclear & -.02 & .05 & .06 \\
\multicolumn{1}{c}{ Total } & $-\$ 6.1$ & $\$ 19.5$ & $\$ 22.0$ \\
\hline
\end{tabular}

A negative figure implies savings with respect to the baseline. 
TABLE B7. INCREMENTAL GROSS INVESTMENT IN FUEL EXPLORATION/PRODUCTIONINTERFUEL SUBSTITUTION STRATEGY, UPPER BOUND CASE ${ }^{\circ}$

(in billions of 1990 dollars)

\begin{tabular}{|c|c|c|c|}
\hline Fuel Type & $1990-2000$ & $2000-2010$ & $2010-2025$ \\
\hline \multicolumn{4}{|l|}{ Coal } \\
\hline $\begin{array}{l}\text { For Electricity } \\
\text { For Other Sectors }\end{array}$ & $\begin{array}{l}\$ 6.0 \\
-16.2\end{array}$ & $\begin{array}{r}-\$ 16.7 \\
-52.3\end{array}$ & $\begin{array}{l}\$ 93.9 \\
-298.7\end{array}$ \\
\hline \multicolumn{4}{|l|}{ Oil } \\
\hline $\begin{array}{l}\text { For Electricity } \\
\text { For Other Sectors }\end{array}$ & $\begin{array}{r}.3 .6 \\
-63.7\end{array}$ & $\begin{array}{r}-14.3 \\
-253.3\end{array}$ & $\begin{array}{r}-64.6 \\
-1,142.2\end{array}$ \\
\hline \multicolumn{4}{|l|}{ Natural Gas } \\
\hline For Electricity & 51.7 & 141.9 & 233.5 \\
\hline For Other Sectors & 91.4 & 174.1 & 204.1 \\
\hline \multicolumn{4}{|l|}{ Nuclear } \\
\hline For Electricity & 0.4 & 3.7 & 78.5 \\
\hline Total & $\$ 54.0$ & $\$ 1.1$ & $-\$ 1,083.2$ \\
\hline
\end{tabular}

${ }^{a}$ A negative figure implies savings with respect to the baseline.

TABLE B8. INCREMENTAL GROSS INVESTMENT IN FUEL EXPLORATION/PRODUCTIONINTERFUEL SUBSTITUTION STRATEGY, UPPER BOUND CASE ${ }^{a}$ (in billions of 1990 dollars)

\begin{tabular}{|c|c|c|c|}
\hline Fuel Type & $\begin{array}{l}\text { Per Year } \\
1990-2000\end{array}$ & $\begin{array}{c}\text { Per Year } \\
2000-2010\end{array}$ & $\begin{array}{c}\text { Per Year } \\
2010-2025\end{array}$ \\
\hline \multicolumn{4}{|l|}{ Coal } \\
\hline For Electricity & $-\$ 0.6$ & $\$ 1.7$ & $-\$ 6.3$ \\
\hline For Other Sectors & -1.6 & -5.2 & -19.9 \\
\hline \multicolumn{4}{|l|}{ Oil } \\
\hline For Electricity & -0.4 & -1.4 & -4.3 \\
\hline For Other Sectors & -6.4 & .25 .5 & -76.1 \\
\hline \multicolumn{4}{|l|}{ Natural Gas } \\
\hline For Electricity & 5.2 & 14.2 & 15.6 \\
\hline For Other Sectors & 9.1 & 17.4 & 13.6 \\
\hline \multicolumn{4}{|l|}{ Nuclear } \\
\hline For Electricity & $0.0^{\mathrm{b}}$ & 0.4 & 5.2 \\
\hline Total & $\$ 5.4$ & $\$ 0.1$ & $\$ 72.2$ \\
\hline
\end{tabular}

${ }^{8}$ A negative figure implies savings with respect to the baseline.

bLess than 0.05 billion dollars 
TABLE B9. INCREMENTAL GROSS INVESTMENT IN FUEL EXPLORATION/ PRODUCTIONTECHNOLOGICAL CHANGE STRATEGY, UPPER BOUND CASE ${ }^{a}$

(in billions of 1990 dollars)

\begin{tabular}{|c|c|c|c|}
\hline Fuel Type & $1990-2000$ & $2000-2010$ & $2010-2025$ \\
\hline \multicolumn{4}{|l|}{ Coal } \\
\hline For Electricity & $-\$ 2.3$ & $\$ 2.2$ & $-\$ 6.1$ \\
\hline For Other Sectors & -8.9 & -45.7 & -209.0 \\
\hline \multicolumn{4}{|l|}{ Oil } \\
\hline For Electricity & .2 .5 & -3.7 & -6.0 \\
\hline For Other Sectors & .63 .1 & -211.6 & 846.3 \\
\hline \multicolumn{4}{|l|}{ Natural Gas } \\
\hline For Electricity & -0.3 & .0 .4 & -0.7 \\
\hline For Other Sectors & -4.0 & -14.1 & -60.5 \\
\hline \multicolumn{4}{|l|}{ Nuclear } \\
\hline For Electricity & 0.1 & 0.3 & 0.9 \\
\hline Total & $-\$ 80.9$ & $-\$ 277.5$ & $-\$ 1,127.9$ \\
\hline
\end{tabular}

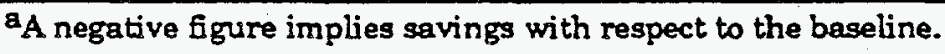

TABLE B10. INCREMENTAL GROSS INVESTMENT IN FUEL EXPLORATION/ PRODUCTION-TECHNOLOGICAL CHANGE STRATEGY, UPPER BOUND CASEa

(in billions of 1990 dollars)

\begin{tabular}{|c|c|c|c|}
\hline Fuel Type & $\begin{array}{c}\text { Per Year } \\
1990-2000\end{array}$ & $\begin{array}{l}\text { Per Year } \\
2000-2010\end{array}$ & $\begin{array}{c}\text { Per Year } \\
2010-2025\end{array}$ \\
\hline \multicolumn{4}{|l|}{ Coal } \\
\hline For Electricity &.$\$ 0.2$ & $\$ 0.2$ & $-\$ 0.4$ \\
\hline For Other Sectors & -0.9 & -4.6 & -13.9 \\
\hline \multicolumn{4}{|l|}{ Oil } \\
\hline For Electricity & -0.2 & -0.4 & -0.4 \\
\hline For Other Sectors & .6 .3 & -21.2 & -56.4 \\
\hline \multicolumn{4}{|l|}{ Natural Gas } \\
\hline For Electricity & $-0.0^{b}$ & $-0.0^{b}$ & $-0.0^{b}$ \\
\hline For Other Sectors & -0.4 & -1.4 & 4.0 \\
\hline \multicolumn{4}{|l|}{ Nuclear } \\
\hline For Electricity & $0.0^{b}$ & $0.0^{\mathrm{b}}$ & 0.1 \\
\hline Total & $-\$ 8.1$ & $-\$ 27.7$ & $-\$ 75.2$ \\
\hline
\end{tabular}

${ }^{a}$ A negative figure implies savings with respect to the baseline.

bLess than 0.05 billion dollars. 
APPENDIX C1:

\section{EXPLORATION/PRODUCTION INVESTMENT SPREADSHEETS}


Flxed Asset investment (from Energy in China) [from National Response .. ]

Investment Per Ton ol Oil Added

Average Production Cost per ton

Other data

Nat Gas - From ' 85 to 90 an investment of 1.78 million Yuan 10 add 100 million m3. (with great variation from basin to basin) [Nat. Response..] or $56.1798 \mathrm{~m}^{3}$ per Yuan invested
Qutput

Coal Mining Petroleum and and Preparation NatGas Extraction

\begin{tabular}{rrr}
1987 & 9,865 & 16,621 \\
1990 & 16.446 & 23.193 \\
\hline
\end{tabular}

$1.667 \quad 1.391$

\begin{tabular}{rrr}
$\begin{array}{c}\text { Coal } \\
\text { (MI) }\end{array}$ & $\begin{array}{r}\text { Oit } \\
(\mathrm{MI})\end{array}$ & $\begin{array}{r}\text { Gas } \\
(10 \times 8 \mathrm{~m} 3)\end{array}$ \\
\hline 926.1 & 134.14 & 138.7 \\
1079.9 & 138.31 & 135.1 \\
\hline
\end{tabular}

Pricelndex $90-80$ Pricelindex '50-85

1.92

\begin{tabular}{rrr}
81.85 & 86.90 & Increase \\
\hline 49.1 & 83.1 & 1.692 \\
43.6 & 177.6 & 4.073
\end{tabular}

Nat Gas . They are developing a ibn dollar project for 100 new wells and 200 refurtish ones. It will add $68 \mathrm{bn}$ m3 of gas during 1995 -2015. [Petroleum Economist]. or

$68 \mathrm{~m}^{3} \mathrm{per}$ collar invested

$1,470,588$ Doilars per $10^{\wedge} 8 \mathrm{~m}^{3}$

Summary Table

Coal

(Yuan per tonne)

(Yuan per tonne)

Gas

15.229

Imvestment/Output for 1990

0.0178

- Expressed in 1990 Yuan 


\begin{tabular}{|c|c|c|c|c|c|}
\hline & & 1990 & 2000 & 2010 & 2025 \\
\hline $\begin{array}{l}\text { Coal Total Produced } \\
\text { Coal for Electricity }\end{array}$ & $\begin{array}{l}\text { (mill Yons per Year) } \\
\text { (mill Tons per Year) }\end{array}$ & $\begin{array}{l}888 \\
283\end{array}$ & $\begin{array}{r}1.935 \\
617\end{array}$ & $\begin{array}{l}3,980 \\
1,268\end{array}$ & $\begin{array}{r}10.223 \\
3.258\end{array}$ \\
\hline $\begin{array}{l}\text { Oil Tolal Produced } \\
\text { Oll lor Electicity }\end{array}$ & $\begin{array}{l}\text { (mill Tons per Year) } \\
\text { (mill Tons per Year) }\end{array}$ & $\begin{array}{r}199 \\
11\end{array}$ & $\begin{array}{r}435 \\
25\end{array}$ & $\begin{array}{r}894 \\
51\end{array}$ & $\begin{array}{r}2297 \\
130\end{array}$ \\
\hline \multirow[t]{2}{*}{$\begin{array}{l}\text { Natural Gas } \\
\text { Nat Gas for Electricty }\end{array}$} & $\begin{array}{l}\text { (1088 MJ per Year) } \\
\text { (1088 MJ per Year) }\end{array}$ & $\begin{array}{r}134 \\
10\end{array}$ & $\begin{array}{r}410 \\
40\end{array}$ & $\begin{array}{r}808 \\
82\end{array}$ & $\begin{array}{r}2.326 \\
209\end{array}$ \\
\hline & $\begin{array}{l}\text { New OivGas - Total } \\
\text { New OilGas - Elec } \\
\text { Oingas Tolal } \\
\text { OivGas Electr }\end{array}$ & $\begin{array}{l}1.4881 \\
1.1385 \\
1.3118 \\
1.1316\end{array}$ & $\begin{array}{l}1.0610 \\
0.6204 \\
1.06618 \\
0.6204\end{array}$ & $\begin{array}{l}1.1061 \\
0.6204 \\
1.1061 \\
0.6204\end{array}$ & $\begin{array}{l}0.9875 \\
0.6204 \\
0.9875 \\
0.6204\end{array}$ \\
\hline
\end{tabular}

TABLE 3. GROSS INVESTMENT IN FOSSIL FUELS
BBASELINE SCENARIOI

\begin{tabular}{|c|c|c|c|c|c|c|c|c|c|c|c|c|c|}
\hline \multirow[b]{3}{*}{$\begin{array}{l}\text { Coal Total Produced } \\
\text { Coal for Electricity }\end{array}$} & \multirow{3}{*}{ 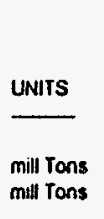 } & \multicolumn{3}{|c|}{ Total Reserves to bo Replaced } & \multicolumn{3}{|c|}{$\begin{array}{l}\text { Investment Required to } \\
\text { Find Additional Reserves } \\
\text { ( in million Yuans) }\end{array}$} & \multicolumn{3}{|c|}{$\begin{array}{l}\text { Invesiment Required to } \\
\text { Increase Production Capacily } \\
\text { (in million Yuans) }\end{array}$} & \multicolumn{3}{|c|}{$\begin{array}{l}\text { Totat Required Inves(ment } \\
\text { (in million Yuans) }\end{array}$} \\
\hline & & $1990-2000$ & $2000-2010$ & $2010-2025$ & 1990-2000 & $2000-2010$ & 2010.2025 & $1990-2000$ & $2000-2010$ & 2010.2025 & $1990-2000$ & $2000-2010$ & $2010-2025$ \\
\hline & & $\begin{array}{r}14,117 \\
4,499\end{array}$ & $\begin{array}{r}29,577 \\
9.426\end{array}$ & $\begin{array}{r}106,519 \\
33,947\end{array}$ & $\begin{array}{l}0 \\
0\end{array}$ & $\begin{array}{l}0 \\
0\end{array}$ & $\begin{array}{l}0 \\
0\end{array}$ & $\begin{array}{r}214,993 \\
68.509\end{array}$ & $\begin{array}{l}450,431 \\
143,549\end{array}$ & $\begin{array}{r}1,622.173 \\
516.976\end{array}$ & $\begin{array}{r}214,993 \\
68,509\end{array}$ & $\begin{array}{l}450.431 \\
143,549\end{array}$ & $\begin{array}{r}1.622 .173 \\
516.976\end{array}$ \\
\hline $\begin{array}{l}\text { Oit Total Produced } \\
\text { Oil for Electricty }\end{array}$ & $\begin{array}{l}\text { mill Tons } \\
\text { mill Jons }\end{array}$ & $\begin{array}{r}3.171 \\
180\end{array}$ & $\begin{array}{r}6.645 \\
376\end{array}$ & $\begin{array}{r}23,933 \\
1,353\end{array}$ & $\begin{array}{r}263,535 \\
14,940\end{array}$ & $\begin{array}{r}552.232 \\
31.228\end{array}$ & $\begin{array}{r}1,988,799 \\
112,463\end{array}$ & $\begin{array}{r}563.223 \\
31.946\end{array}$ & $\begin{array}{r}1.180,222 \\
66,740\end{array}$ & $\begin{array}{r}4.250,429 \\
240,355\end{array}$ & $\begin{array}{r}826,758 \\
46,894\end{array}$ & $\begin{array}{r}1.732 .454 \\
97.967\end{array}$ & $\begin{array}{r}6.239 .228 \\
352.818\end{array}$ \\
\hline $\begin{array}{l}\text { Naturat Gas } \\
\text { Nat Gas lor Electricty }\end{array}$ & $\begin{array}{l}-10 \times 8 \mathrm{m3} \\
.1008 \mathrm{m3}\end{array}$ & $\begin{array}{r}2.718 \\
248\end{array}$ & $\begin{array}{r}6.090 \\
606\end{array}$ & $\begin{array}{r}23,507 \\
2.182\end{array}$ & $\begin{array}{r}21,606 \\
1,973\end{array}$ & $\begin{array}{r}48,414 \\
4,816\end{array}$ & $\begin{array}{r}186,879 \\
17,343\end{array}$ & $\begin{array}{r}29.895 \\
2.730\end{array}$ & $\begin{array}{r}66,988 \\
6,663\end{array}$ & $\begin{array}{r}258,575 \\
23,997\end{array}$ & $\begin{array}{r}51.501 \\
4.703\end{array}$ & $\begin{array}{r}115.402 \\
11.479\end{array}$ & $\begin{array}{r}445,453 \\
41,340\end{array}$ \\
\hline
\end{tabular}

TABLE 3A. GROSS INVESTMENT IN FOSSIL FUELS. DOLLARS

[BASELINE SCENARIO]

\begin{tabular}{|c|c|c|c|c|c|c|c|c|c|c|c|c|c|c|}
\hline & \multirow[t]{2}{*}{ 1 USS $=$} & \multicolumn{4}{|c|}{$\begin{array}{l}\text { 4.78 Yuan } \\
\text { Tolal Reserves to bo Replaced }\end{array}$} & \multicolumn{3}{|c|}{$\begin{array}{l}\text { Investment Required to } \\
\text { Find Additional Reserves } \\
\text { ( in miltion US Dollars) }\end{array}$} & \multicolumn{3}{|c|}{$\begin{array}{l}\text { Invesiment Required io } \\
\text { increase Production Capacily } \\
\text { (in million US Dollars) }\end{array}$} & \multicolumn{3}{|c|}{$\begin{array}{l}\text { Total Required Investment } \\
\text { (in million US Dollars) }\end{array}$} \\
\hline & & UNITS & $1990-2000$ & $2000-2010$ & $2010-2025$ & $1990-2000$ & $2000-2010$ & $2010-2025$ & $1990-2000$ & $2000-2010$ & $2010-2025$ & 1990.2000 & $2000-2010$ & $2010-2025$ \\
\hline $\begin{array}{l}\text { Coal Total Produced } \\
\text { Coat for Electricily }\end{array}$ & & $\begin{array}{l}\text { mill Tons } \\
\text { mill Tons }\end{array}$ & $\begin{array}{r}14,117 \\
4,499\end{array}$ & $\begin{array}{r}29,577 \\
9,426\end{array}$ & $\begin{array}{r}106.519 \\
33,947\end{array}$ & $\begin{array}{l}0 \\
0\end{array}$ & $\begin{array}{l}0 \\
0\end{array}$ & $\begin{array}{l}0 \\
0\end{array}$ & $\begin{array}{l}44,978 \\
14,332\end{array}$ & $\begin{array}{l}94.232 \\
30,031\end{array}$ & $\begin{array}{l}339.367 \\
108.154\end{array}$ & $\begin{array}{l}44,978 \\
14,332\end{array}$ & $\begin{array}{l}94,232 \\
30,031\end{array}$ & $\begin{array}{l}339.367 \\
108.154\end{array}$ \\
\hline $\begin{array}{l}\text { Oil Total Produced } \\
\text { Oil lor Electricily }\end{array}$ & & $\begin{array}{l}\text { mill Tons } \\
\text { mill Tons }\end{array}$ & $\begin{array}{r}3.171 \\
180\end{array}$ & $\begin{array}{r}6.645 \\
376\end{array}$ & $\begin{array}{r}23.933 \\
1.353\end{array}$ & $\begin{array}{r}55,133 \\
3,127\end{array}$ & $\begin{array}{r}115.530 \\
6.533\end{array}$ & $\begin{array}{r}416,067 \\
23,528\end{array}$ & $\begin{array}{r}117.829 \\
6,683\end{array}$ & $\begin{array}{r}246.908 \\
13,962\end{array}$ & $\begin{array}{r}889,211 \\
50,283\end{array}$ & $\begin{array}{r}172.962 \\
9.811\end{array}$ & $\begin{array}{r}362.438 \\
20.495\end{array}$ & $\begin{array}{r}1.305 .278 \\
73,811\end{array}$ \\
\hline $\begin{array}{l}\text { Natural Gas Total } \\
\text { Nat Gas for Electricty }\end{array}$ & & $\begin{array}{l}1048 \mathrm{m3} \\
10 \times 8 \mathrm{m3}\end{array}$ & $\begin{array}{r}2.718 \\
248\end{array}$ & $\begin{array}{r}6,090 \\
606\end{array}$ & $\begin{array}{r}23,507 \\
2,182\end{array}$ & $\begin{array}{r}4.520 \\
413\end{array}$ & $\begin{array}{r}10.128 \\
1.007\end{array}$ & $\begin{array}{r}39,096 \\
3,628\end{array}$ & $\begin{array}{r}6.254 \\
571\end{array}$ & $\begin{array}{r}14.014 \\
1,394\end{array}$ & $\begin{array}{r}54,095 \\
5,020\end{array}$ & $\begin{array}{r}10.774 \\
904\end{array}$ & $\begin{array}{r}24,143 \\
2,401\end{array}$ & $\begin{array}{r}93,191 \\
8,649\end{array}$ \\
\hline
\end{tabular}


STRATEGY 3 CALCULATIONS

COAL

in 1990:

Coal Based Electric Output

Coal Used

Coericient

Total Electricily Dem.(mill Yuan)

Electricity from Coal

Electricity from Coal(Yuan)

Coal for Electricily(mill Tons)

* of Coal Interm. Demand used for Elect

Total Coal

Oil Based Electric Output

Oil Used

oll

In 1990

Total Electricity Demand (mill Yuan)

Electricity from Oit

Electricity from Cil(Yuan)

Oil for Electricty(mill Tons)

x of OA interm Demand used for Elect.

Total O

\subsection{4 mill Yuan}

283 mill Tons

166.375 Yuan of electricity per fon of Caal

$\begin{array}{rrr}2000 & 2010 & 2025 \\ 142,000 & 292,000 & 750,000 \\ 28.1 \% & 34.1 \% & 0.0 \% \\ 39,902 & 99.572 & 0 \\ 240 & 598 & 0 \\ 31.9 \% & 31.9 \% & 31.9 \% \\ 753 & 1.878 & 200\end{array}$

$\begin{array}{rrr}2000 & 2010 & 2025 \\ 142,000 & 292,000 & 750,000 \\ 3.4 \% & 1.6 \% & 0.6 \% \\ 4,757 & 4.760 & 4,725 \\ 11.316 & 11.322 & 11.240 \\ 5.7 \% & 5.7 \% & 5.7 \% \\ 200 & 200 & 199\end{array}$

4,742 mill Yuan

11.281 mily Tons

420.398 Yuan of electricity per Ton or Oit 


\begin{tabular}{llrrr}
\hline TABLE I. CAPIIAL COSIS FOR EXPLO RATION ANO DEVELOPMENT OF FOSSIL FUELS & \\
\hline & & & & \\
& & Exploration & Production & Tolal \\
\hline Caal & (Yuan per tonne) & 0 & 15.2 & 15.229 \\
Oil & (Yuan per tonne) & 83.1 & 177.6 & 260.7 \\
Nalural Gas & (Yuan per m3) & 0.080 & 0.110 & 0.190
\end{tabular}

TABLE 2 PROJECTEO FOSSIL FUELS CAPACIY REOUIREMENTS

[STRATEGY 3]

\begin{tabular}{llrrrr}
\hline & & 1990 & 2000 & 2010 & 2025 \\
\hline Coal Toal Produced & (mill Tons per Year) & 1.055 & 753 & 1.878 & 200 \\
Coal for Electricity & (mill Tons per Year) & 283 & 240 & 598 & 0 \\
Oil Total Produced & (mill Yons per Year) & 201 & 200 & 200 & 199 \\
Oil for Electricily & (mill Tons per Year) & 11 & 11 & 11 & 11 \\
Natural Gas & $\left(10^{\circ} 8 \mathrm{M3}\right.$ per Year) & 153 & 5.000 & 5.000 & 5.000 \\
Nat Gas for Electricty & $\left(10^{\circ} 8 \mathrm{M3}\right.$ per Year) & 10 & 2.649 & 4.631 & 3.512 \\
\hline
\end{tabular}

TABLE 3. GROSS INESTMENT IN FOSSIL FUELS

[SIRATEGY 3 ]

\begin{tabular}{|c|c|c|c|c|c|c|c|c|c|c|c|c|c|}
\hline & \multirow[b]{2}{*}{ UNITS } & \multicolumn{3}{|c|}{ Total Reserves to be Replaced } & \multicolumn{3}{|c|}{$\begin{array}{l}\text { Investment Required to } \\
\text { Find Additional Reserves } \\
\text { (In million Yuans) }\end{array}$} & \multicolumn{3}{|c|}{$\begin{array}{l}\text { Imvestment Required to } \\
\text { Increase Production Capacity } \\
\text { (in million Yuans) }\end{array}$} & \multicolumn{3}{|c|}{$\begin{array}{l}\text { Total Required investment } \\
\text { (in million Yuans) }\end{array}$} \\
\hline & & 1990.2000 & $2000 \cdot 2010$ & $2010-2025$ & 1990.2000 & $2000-2010$ & $2010-2025$ & 1990.2000 & $2000-2010^{\circ}$ & $2010-2025$ & $1990-2000$ & $2000-2010$ & $2010-2025$ \\
\hline $\begin{array}{l}\text { Coal Total Produced } \\
\text { Coal lor Electricity }\end{array}$ & $\begin{array}{l}\text { mill Tons } \\
\text { mill Tons }\end{array}$ & $\begin{array}{l}9,038 \\
2,614\end{array}$ & $\begin{array}{r}13,152 \\
4.192\end{array}$ & $\begin{array}{r}15.584 \\
4.489\end{array}$ & $\begin{array}{l}0 \\
0\end{array}$ & $\begin{array}{l}0 \\
0\end{array}$ & $\begin{array}{l}0 \\
0\end{array}$ & $\begin{array}{r}137,636 \\
39,803\end{array}$ & $\begin{array}{r}200.296 \\
63.833\end{array}$ & $\begin{array}{r}237,334 \\
68,357\end{array}$ & $\begin{array}{r}137.636 \\
39.803\end{array}$ & $\begin{array}{r}200,296 \\
63,833\end{array}$ & $\begin{array}{r}237.334 \\
68.357\end{array}$ \\
\hline $\begin{array}{l}\text { Oil Tolal Produced } \\
\text { Oil lor Electricity }\end{array}$ & $\begin{array}{l}\text { mill Tons } \\
\text { mill Tons }\end{array}$ & $\begin{array}{r}2.004 \\
113\end{array}$ & $\begin{array}{r}2,001 \\
113\end{array}$ & $\begin{array}{r}2.991 \\
169\end{array}$ & $\begin{array}{r}166.497 \\
9.403\end{array}$ & $\begin{array}{r}166.257 \\
9.406\end{array}$ & $\begin{array}{r}248,547 \\
14,061\end{array}$ & $\begin{array}{r}355.834 \\
20,097\end{array}$ & $\begin{array}{r}355,322 \\
20,102\end{array}$ & $\begin{array}{r}531,190 \\
30,052\end{array}$ & $\begin{array}{r}522.331 \\
29.500\end{array}$ & $\begin{array}{r}521,579 \\
29,500\end{array}$ & $\begin{array}{r}779,737 \\
44.113\end{array}$ \\
\hline $\begin{array}{l}\text { Naturat Gas } \\
\text { Nat Gas Ior Electricty }\end{array}$ & $\begin{array}{l}10^{\wedge} 8 \mathrm{m3} \\
10^{\wedge} 8 \mathrm{m3}\end{array}$ & $\begin{array}{l}25.765 \\
13,296\end{array}$ & $\begin{array}{l}50,000 \\
36,401\end{array}$ & $\begin{array}{l}75,000 \\
61,075\end{array}$ & $\begin{array}{l}204,832 \\
105,705\end{array}$ & $\begin{array}{l}397,500 \\
289,386\end{array}$ & $\begin{array}{l}596.250 \\
485.548\end{array}$ & $\begin{array}{l}283.415 \\
146.259\end{array}$ & $\begin{array}{l}550,000 \\
400,408\end{array}$ & $\begin{array}{l}825,000 \\
671,827\end{array}$ & $\begin{array}{l}488,247 \\
251,964\end{array}$ & $\begin{array}{l}947.500 \\
689.794\end{array}$ & $\begin{array}{l}1.421,250 \\
1.157 .375\end{array}$ \\
\hline
\end{tabular}




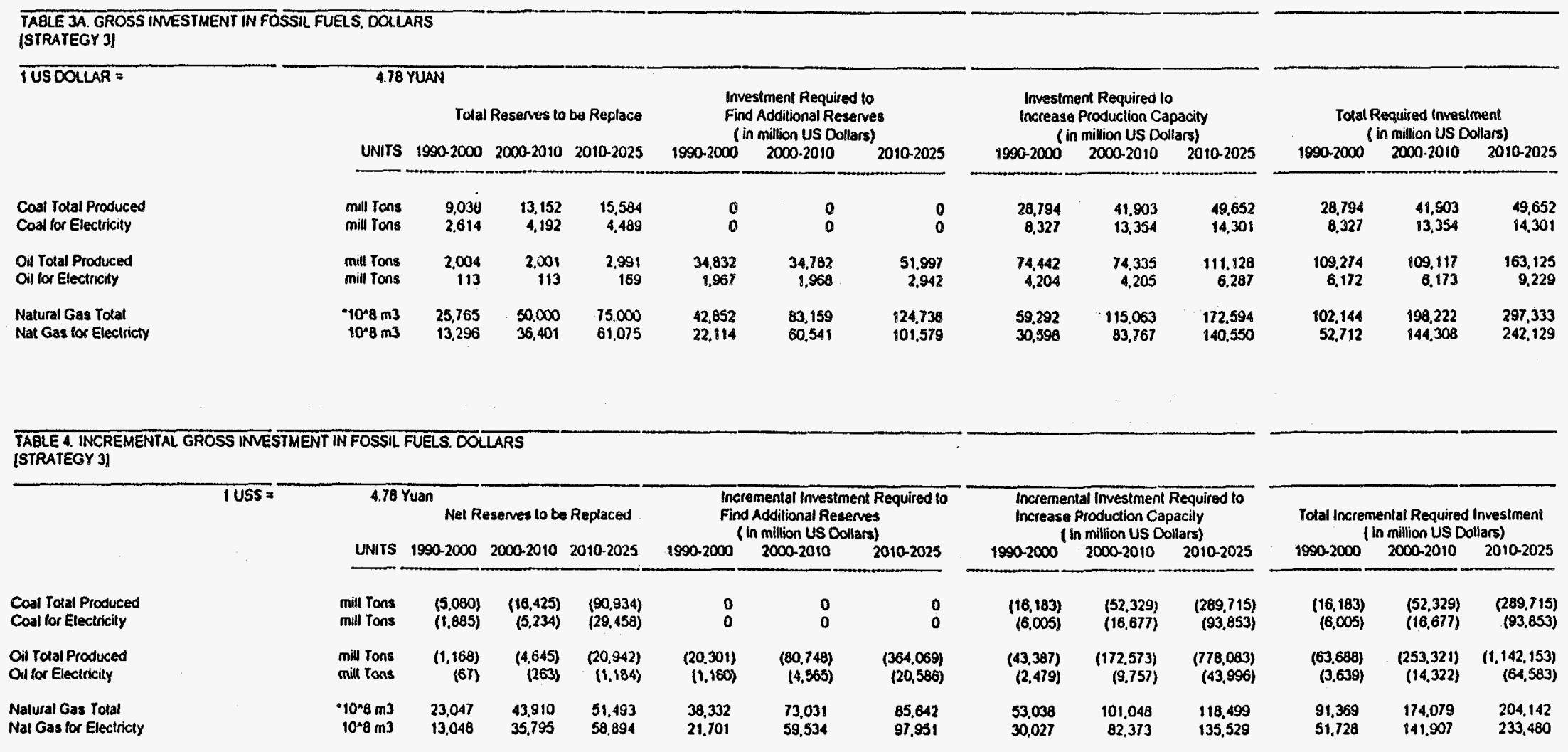


STRATEGY 4 CALCULATIONS

Technical Coefficients for Strategy 4 - Electricity

Dala From 10 rable

Gross Output Seclor 11

Coal Ciude + Gas

Oil

Modificalion to add Petroleum Producls

Coal Pertucts

Gas

Iechnlcal Matrix A

Pelis Products

Gas 4 Srategr 4 Electric Projection

Stralear 4 Elecelinc Proictic Demand

(mull Yuan)

Fuel Reguirements For Electricity LA* TotElecDemandl(mill Yuan)

Coal $\quad 19,700 \quad 53,176 \quad 125,142$

$\begin{array}{lrrr}\text { Petroleum Products } & 11.440 & 33.404 & \mathbf{8 7 . 5 2 6}\end{array}$

$574 \quad 1.675 \quad 4.389$

Fuel Requirements for Elecctricily in Volume

Gas( $(10 \times 8$ macts (mill ton)

$\begin{array}{rrr}472 & 1,273 & 2,997 \\ 16 & 46 & 120 \\ 25 & 74 & 193\end{array}$

Fuel for All intermediale Uses (in Billion Yuan) Petr Products

Gas

Fuel lor Intermediale in the Econony in Volume Coal (mill ton)

Gas('1018 m3)

Shares of Tolal Intermediale Demand

Pert Products

Total Oulput In Billion Yuan

Potr Producls

Gas

$50.6 \quad 76.7 \quad 151.1$

$\begin{array}{rrr}147.7 & 256.0 & 562.9 \\ 4.3 & 7.2 & 17.7\end{array}$

$\begin{array}{rrr}1.211 & 1.836 & 3.618 \\ 202 & 351 & 771\end{array}$

$\begin{array}{lll}202 & 351 & 771 \\ 191 & 317 & 781\end{array}$

$39.0 \% \quad 69.3 \% \quad 82.8 \%$

$\begin{array}{rrr}7.7 \% & 13.0 \% & 15.5 \% \\ 13.3 \% & 23.3 \% & 24.8 \%\end{array}$

$\begin{array}{rrr}81.6 & 141.7 & 318.9 \\ 105.0 & 187.2 & 481.0 \\ 79.7 & 141.7 & 355.6\end{array}$

$\begin{array}{lll}79.1 & 187.2 & 481.0 \\ & & 365.6\end{array}$
Total Fues Output for Intermediate Sectors - Strategy 4

\begin{tabular}{|c|c|c|c|}
\hline & $\begin{array}{r}\text { illion Yuan } \\
2000\end{array}$ & 2010 & 2025 \\
\hline $\begin{array}{l}\text { Coal } \\
\text { Petr Products } \\
\text { Nal Gas }\end{array}$ & $\begin{array}{r}50.6 \\
147.7 \\
4.3\end{array}$ & $\begin{array}{r}78.7 \\
256.0 \\
7.2\end{array}$ & $\begin{array}{r}151.1 \\
562.9 \\
17.7\end{array}$ \\
\hline $\begin{array}{l}\text { Fraction } \\
\text { Coal } \\
\text { Petr Producls } \\
\text { Gas }\end{array}$ & $\begin{array}{r}38.97 \% \\
7.75 \% \\
13.26 \%\end{array}$ & $\begin{array}{l}69.34 x \\
13.05 x \\
23.26 x\end{array}$ & $\begin{array}{l}82.84 x \\
15.55 \% \\
24.75 x\end{array}$ \\
\hline \multicolumn{4}{|l|}{ Pilces } \\
\hline & Coal & Petr Prod & Natural Gas \\
\hline Oulput $\mathbf{9 0}$ (mill Yuan & 45,096 & 100,946 & 3,087 \\
\hline Price 90 (Yuan) & $\begin{array}{l}41.7590 \\
\text { Yuanton }\end{array}$ & $\begin{array}{l}729.8512 \\
\text { Yuarnon }\end{array}$ & $\begin{array}{r}0.2270 \\
\text { Yuan/m3 }\end{array}$ \\
\hline & $\begin{array}{l}1079.9 \\
1079.9\end{array}$ & $\begin{array}{l}138.31 \\
838.31\end{array}$ & $\begin{array}{l}13510 \\
835.8\end{array}$ \\
\hline $\begin{array}{l}\text { Price } 90 \\
\text { Coal } \\
\text { OII } \\
\text { Gas }\end{array}$ & $\begin{array}{r}41.759 \\
729.851 \\
0.227\end{array}$ & & \\
\hline
\end{tabular}




\begin{tabular}{|c|c|c|c|c|c|}
\hline & & 1990 & 2000 & 2010 & 2025 \\
\hline $\begin{array}{l}\text { Coal Total Produced } \\
\text { Cost for Electricity }\end{array}$ & $\begin{array}{l}\text { (mill Tons per Year) } \\
\text { (mill Tons per Year) }\end{array}$ & $\begin{array}{r}1.055 \\
283\end{array}$ & $\begin{array}{r}1,211 \\
472\end{array}$ & $\begin{array}{l}1.836 \\
1.273\end{array}$ & $\begin{array}{l}3,618 \\
2.997\end{array}$ \\
\hline $\begin{array}{l}\text { Oil Total Produced } \\
\text { Oil for Electricity }\end{array}$ & $\begin{array}{l}\text { (mill Tons per Year) } \\
\text { (mill Tons per Year) }\end{array}$ & $\begin{array}{r}201 \\
11\end{array}$ & $\begin{array}{r}202 \\
16\end{array}$ & $\begin{array}{r}351 \\
46\end{array}$ & $\begin{array}{l}778 \\
120\end{array}$ \\
\hline $\begin{array}{l}\text { Natural Gas } \\
\text { Nal Gas for Electricty }\end{array}$ & $\begin{array}{l}\text { (10.8 M3 per Year) } \\
\text { (10.8 M3 per Year) }\end{array}$ & $\begin{array}{r}153 \\
10\end{array}$ & $\begin{array}{r}191 \\
25\end{array}$ & $\begin{array}{r}317 \\
74\end{array}$ & $\begin{array}{l}781 \\
193\end{array}$ \\
\hline & $\begin{array}{l}\text { OVGas Tolal } \\
\text { OWGas Electr }\end{array}$ & $\begin{array}{l}1.3118 \\
1.1316\end{array}$ & $\begin{array}{l}1.0618 \\
0.6204\end{array}$ & $\begin{array}{l}1.1061 \\
0.6204\end{array}$ & $\begin{array}{l}0.9875 \\
0.6204\end{array}$ \\
\hline
\end{tabular}

\section{TABLE 3. GROSS INVESIMENT INFOSSIL FUELS}

[STRATEGY 4]

\begin{tabular}{|c|c|c|c|c|c|c|c|}
\hline \multirow[b]{3}{*}{$\begin{array}{l}\text { Coal Total Produced } \\
\text { Coal Ior Electricity }\end{array}$} & \multirow{3}{*}{$\begin{array}{l}\text { UNITS } \\
\text { mill Tons } \\
\text { mill rons }\end{array}$} & \multicolumn{3}{|c|}{ Tolal Reserves to be Replaced } & \multicolumn{3}{|c|}{$\begin{array}{l}\text { Investment Required to } \\
\text { Find Additional Reserves } \\
\text { (in million Yuans) }\end{array}$} \\
\hline & & $1990-2000$ & 2000-2010 & $2010-2025$ & $1990-2000$ & $2000-2010$ & $2010-2025$ \\
\hline & & $\begin{array}{r}11.328 \\
3.773\end{array}$ & $\begin{array}{r}15.236 \\
8.726\end{array}$ & $\begin{array}{l}40,906 \\
32,026\end{array}$ & $\begin{array}{l}0 \\
0\end{array}$ & $\begin{array}{l}0 \\
0\end{array}$ & $\begin{array}{l}0 \\
0\end{array}$ \\
\hline $\begin{array}{l}\text { Oll Total Produced } \\
\text { Oll for Electricity }\end{array}$ & $\begin{array}{l}\text { mill Tons } \\
\text { mill Tons }\end{array}$ & $\begin{array}{r}2.015 \\
135\end{array}$ & $\begin{array}{r}2.766 \\
307\end{array}$ & $\begin{array}{l}8.415 \\
1.243\end{array}$ & $\begin{array}{r}167.464 \\
11.215\end{array}$ & $\begin{array}{r}229.830 \\
25.530\end{array}$ & $\begin{array}{l}699,301 \\
103,267\end{array}$ \\
\hline $\begin{array}{l}\text { Nalurat Gas } \\
\text { Nat Gas for Electricty }\end{array}$ & $\begin{array}{l}\cdot 10^{\wedge} 8 \mathrm{~m} 3 \\
\cdot 10^{\prime} 8 \mathrm{~m} 3\end{array}$ & $\begin{array}{r}1.718 \\
178\end{array}$ & $\begin{array}{r}2.539 \\
495\end{array}$ & $\begin{array}{l}8,236 \\
2,003\end{array}$ & $\begin{array}{r}13,657 \\
1.402\end{array}$ & $\begin{array}{r}20,181 \\
3,937\end{array}$ & $\begin{array}{l}65,475 \\
15,925\end{array}$ \\
\hline
\end{tabular}

\begin{tabular}{|c|c|c|}
\hline \multicolumn{3}{|c|}{$\begin{array}{l}\text { Investment Required to } \\
\text { Increase Production Capacity } \\
\text { (in million Yuans) }\end{array}$} \\
\hline $1990-2000$ & $2000-2010$ & 2010-2025 \\
\hline $\begin{array}{r}172.515 \\
57.463\end{array}$ & $\begin{array}{r}232,022 \\
132,885\end{array}$ & $\begin{array}{l}622.960 \\
487.729\end{array}$ \\
\hline $\begin{array}{r}357,902 \\
23,968\end{array}$ & $\begin{array}{r}491,188 \\
54,561\end{array}$ & $\begin{array}{r}1.494,535 \\
220,700\end{array}$ \\
\hline $\begin{array}{r}18.896 \\
1,940\end{array}$ & $\begin{array}{r}27.924 \\
5.447\end{array}$ & $\begin{array}{l}90,594 \\
22,035\end{array}$ \\
\hline
\end{tabular}

\begin{tabular}{|c|c|c|}
\hline \multicolumn{3}{|c|}{$\begin{array}{l}\text { Tokal Required Imvestment } \\
\text { (in million Yuans) }\end{array}$} \\
\hline $1990-2000^{\circ}$ & $2000-2010$ & 2010-2025 \\
\hline $\begin{array}{r}172,515 \\
57,463\end{array}$ & $\begin{array}{l}232,022 \\
132,885\end{array}$ & $\begin{array}{l}622.960 \\
487.729\end{array}$ \\
\hline $\begin{array}{r}525,366 \\
35,183\end{array}$ & $\begin{array}{r}721,018 \\
80,091\end{array}$ & $\begin{array}{r}2,193,836 \\
323,066\end{array}$ \\
\hline $\begin{array}{r}32.553 \\
3.342\end{array}$ & $\begin{array}{r}48.105 \\
9.384\end{array}$ & $\begin{array}{r}156,069 \\
37,960\end{array}$ \\
\hline
\end{tabular}


TABLE 3A. GROSS INEESTMENT IN FOSSIL FUELS, DOLLARS

[STRAIEGY 4]

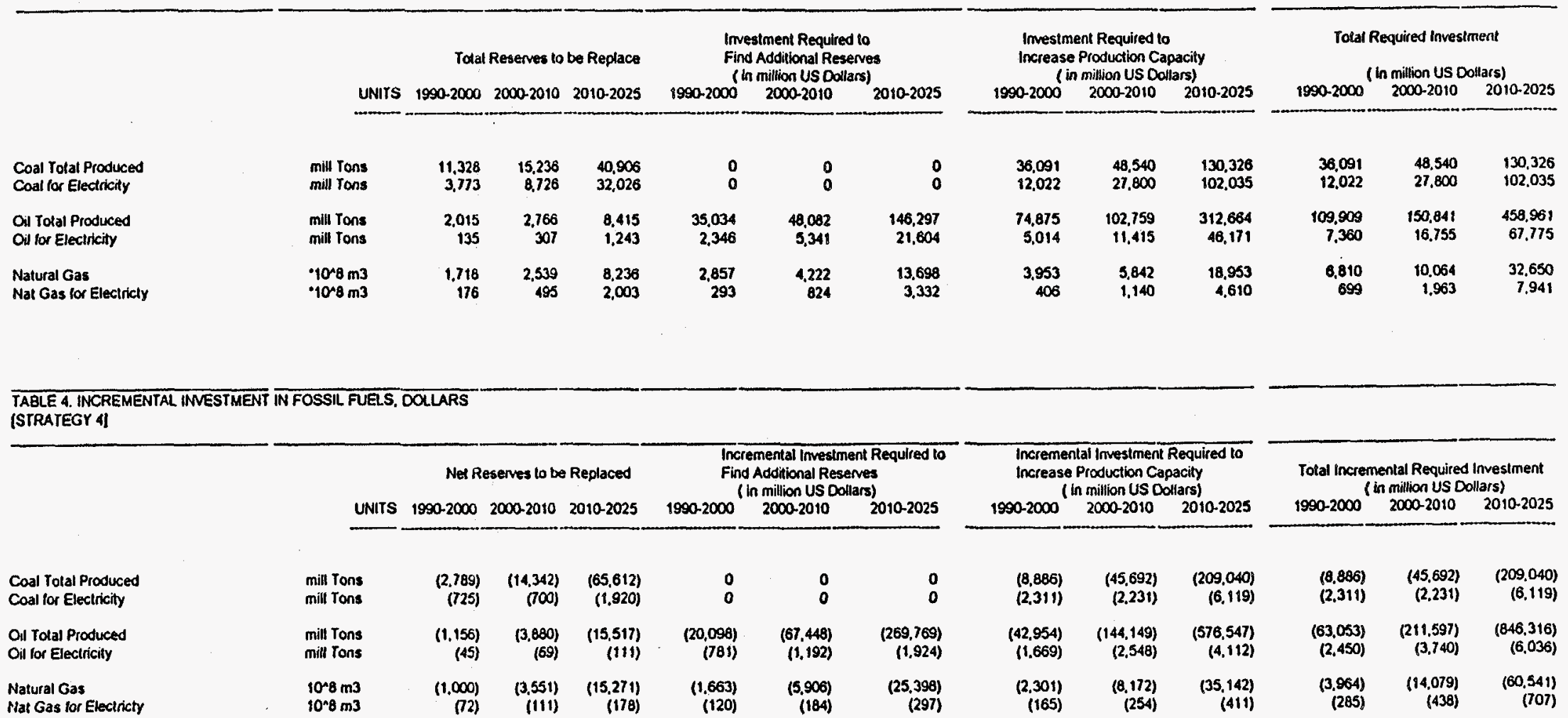




\section{CALCULATIONS FOR NUCLEAR GROWTH}

Imvestment of Coat 1990

Sales of Coal trom Electricity. 1990

Coeticient

Nuclear Share in 9990
16,446 Yuan

47,084 miltion Yuan

0.349 Yuan Imested per Yuan of Eectric Output

$0.29 \%$

\begin{tabular}{|c|c|c|c|c|c|c|c|}
\hline & 1990 & 2000 & 2010 & 2025 & $1990-2000$ & $2000-2010$ & $2010-2025$ \\
\hline Baseline & 0.19 & 0.19 & 0.19 & 0.19 & $100.0 \%$ & $100.0 \%$ & $100.0 \%$ \\
\hline Strotegy 3 & 0.19 & 1.44 & 10.86 & 225.00 & $753.9 \%$ & $754.4 x$ & $2071.3 \%$ \\
\hline Strateoy 4 & 0.19 & 0.35 & 1.02 & 2.82 & $184.7 \%$ & $288.4 \%$ & $257.9 \%$ \\
\hline
\end{tabular}

TABLE 6. INESTMENT FOR NUCLEAR FUEL, BILLION DOLLARS (investment coeficient from above times the amoun of elect nuclear sales)

\begin{tabular}{lccccc}
\hline & 1990 & 2000 & 2010 & 2025 \\
\cline { 2 - 5 } Baseline & 0.1 & 0.1 & 0.1 & 0.1 \\
Sualegy 3 & 0.1 & 0.5 & 3.8 & 78.6 \\
Surategy 4 & 0.1 & 0.1 & 0.4 & 0.9
\end{tabular}

TABLE 7. INKCREMENTAL INVESTMENT FOR NUCLEAR FUEL, BILLION DOLLARS

\begin{tabular}{llllll}
\hline & 1990 & 2000 & 2010. & 2025 \\
\cline { 2 - 4 } & & 0.000 & 0.436 & 3.728 & 78.524 \\
Strategy 3 & 0.000 & 0.056 & 0.289 & 0.850
\end{tabular}


APPENDIX C2:

GENERATION/TRANSMISSION INVESTMENT SPREADSHEETS 


\begin{tabular}{|c|c|c|c|c|c|c|c|c|c|c|c|}
\hline \multirow[t]{2}{*}{ Sualegy 3. U. BOUND } & HIGH GROWTH OF RATE & & & & \multicolumn{2}{|c|}{ BUSINESS AS USUAL } & & \multirow[b]{3}{*}{2025} & \multirow[b]{3}{*}{$(B S / G W), \mathbf{G}$} & \multirow[b]{3}{*}{$(+T+O)$} & \multirow[b]{3}{*}{$(B S / M W), G I D$} \\
\hline & MIX(\%MICE $)$ & & & & \multicolumn{2}{|c|}{ MIX $\%$ MCTE) } & \multirow[b]{2}{*}{2010} & & & & \\
\hline YEAR & 1990 & 2000 & 2010 & 2025 & 1990 & 2000 & & & & & \\
\hline COAL & 72.27 & 28.2 & 34.1 & 0 & 72.27 & 72.27 & 72.27 & 72.27 & $\begin{array}{r}1.106 \\
\end{array}$ & 0.2212 & \begin{tabular}{|l}
1.3272 \\
\end{tabular} \\
\hline $\mathrm{OL}$ & 7.3 & 3.3 & 1.6 & 0.7 & 7.3 & 7.3 & 7.3 & 7.3 & 0.79 & 0.2212 & 1.0112 \\
\hline MATURAL GAS & 0.41 & 50 & 42.5 & 12.86 & 0.41 & 0.41 & 0.41 & 0.41 & 0.527 & 0.2212 & 0.7482 \\
\hline HOPO & 20.01 & 17.2 & 15.7 & 15.7 & 20.01 & 20.01 & 20.01 & 20.01 & 1.216 & 0.2212 & 1.4372 \\
\hline \multirow[t]{2}{*}{ MEGAR } & 0.2 & 1.3 & 6.1 & 71 & 0.2 & 0.2 & 0.2 & 0.2 & 1.52 & 0.2212 & 1.7412 \\
\hline & & & & & & & & & & & \\
\hline DEMAND (TIMES BASELNE) & 1.00 & 2.18 & 4.48 & -11.51 & 1.00 & 2.18 & 4.48 & 11.51 & & & \\
\hline \multirow[t]{2}{*}{ TORAL CAPACTY $/ \mathrm{GM}$} & $\begin{array}{r}137.89 \\
\end{array}$ & 300.56 & 618.06 & 1587.47 & +37.89 & 300.56 & 618.06 & 1587.47 & & & \\
\hline & CAPACITY BY FUEL $(\mathrm{GW}$ ) & & & & & & & & & & \\
\hline COAL & 99.65 & 84.76 & 210.76 & 0.00 & 99.65 & 217.22 & 446.67 & 1147.27 & & & \\
\hline oL & 10.07 & 9.92 & 9.89 & 11.11 & 10.07 & 21.94 & 45.12 & 115.89 & & & \\
\hline MATURAL GAS & 0.57 & 150.28 & 262.67 & 204.15 & 0.57 & 1.23 & 2.53 & 6.51 & & & \\
\hline IMOAO & 27.59 & 51.70 & 97.03 & 249.23 & 27.59 & 60.14 & 123.67 & 317.65 & & & \\
\hline \multirow[t]{3}{*}{ MUKEAR } & 0.28 & 3.91 & 37.70 & 1127.11 & 0.28 & 0.60 & 1.24 & 3.17 & & & \\
\hline & NET INVT. BY FUEL IGW & & & & & & & & & & \\
\hline & & $1990-2000$ & 2000.2010 & $2010-2025$ & & 1990.2000 & $2000-2010$ & $2010 \cdot 2015$ & & & \\
\hline COAL & & 0.00 & 126.00 & 0.00 & & 117.56 & 229.45 & 700.60 & & & \\
\hline $\mathrm{O}$ & & 0.00 & 0.00 & 1.22 & & 11.88 & 23.18 & 70.77 & & & \\
\hline MATURAL GAS & & 149.72 & 112.39 & 0.00 & $\div$ & 0.67 & 1.30 & 3.97 & & & \\
\hline IMOPO & & 24.10 & 45.34 & 152.20 & & 32.55 & 63.53 & 193.98 & & & \\
\hline \multirow[t]{3}{*}{ NQEAA } & & 3.63 & 33.79 & 1089.40 & & 0.33 & 0.63 & 1.94 & & & \\
\hline & TOTAL NET MW & 177.45 & 317.52 & 1242.83 & & 162.98 & 318.10 & 971.26 & & & \\
\hline & NET INVT. BY FUEL (BO). & & & & & & & & \multicolumn{3}{|c|}{ INV(3-U) - INV(BASUSUAL) } \\
\hline COAL & & 0.00 & 167.23 & 0.00 & & 156.03 & 304.53 & 929.83 & \begin{tabular}{|l|}
-156.03 \\
\end{tabular} & \begin{tabular}{|r|}
.137 .30 \\
\end{tabular} & .929 .83 \\
\hline $\mathrm{a}$ & & 0.00 & 0.00 & 1.24 & & 12.01 & 23.44 & 71.56 & .12 .01 & -23.44 & -.70 .32 \\
\hline NAIURAL GAS & & 112.02 & 84.09 & 0.00 & & 0.50 & 0.97 & 2.97 & 111.52 & 83.12 & .2 .97 \\
\hline MMOPO & & 34.64 & 65.16 & 218.74 & & 46.78 & 91.31 & 278.79 & -12.14 & .26 .15 & -60.05 \\
\hline \multirow[t]{3}{*}{ MQLEAR } & & 6.32 & 58.84 & 1896.87 & & 0.57 & 1.11 & 3.38 & 5.76 & 57.74 & 1893.49 \\
\hline & TOTAL NET INV. (BD) & 152.98 & 375.32 & 2116.85 & & 215.88 & 421.35 & 1286.53 & .62 .90 & .46 .03 & 830.32 \\
\hline & \multicolumn{2}{|l|}{ GROSS NNT BY FUEL IGM } & & & & & & & & & \\
\hline COAL & & 18.29 & 154.22 & 0.00 & & 150.75 & 301.79 & 923.93 & & & \\
\hline$\underline{\underline{L}}$ & & 3.20 & 3.27 & 6.17 & & 15.23 & 30.48 & 93.33 & & & \\
\hline MaTURAL GAS & & 149.90 & 162.44 & 72.81 & & 0.86 & 1.71 & 5.24 & & & \\
\hline MOAO & & 33.29 & 62.55 & 200.72 & & 41.74 & 83.56 & 255.82 & & & \\
\hline \multirow[t]{3}{*}{ WUAEAR } & & 3.72 & 35.10 & 1108.25 & & 0.42 & 0.84 & 2.56 & & & \\
\hline & TOTAL GAOSS GW & 200.41 & 417.58 & 1387.95 & & 208.99 & 418.37 & 1280.87 & & & \\
\hline & GROSS WN. BY FUEL $(B O)$ & & & & & & & & \multicolumn{3}{|c|}{ INV(3-U) - INV(BASUSUAL) } \\
\hline COAL & & 24.27 & 204.69 & 0.00 & & 200.07 & 400.53 & 1226.24 & \begin{tabular}{|r|}
-175.80 \\
\end{tabular} & \begin{tabular}{|l|}
-195.85 \\
\end{tabular} & .1226 .24 \\
\hline $\mathrm{OL}$ & & 3.24 & 3.31 & 6.24 & & 15.40 & 30.82 & 94.37 & .12 .16 & -27.51 & +88.13 \\
\hline MATUPAL GAS & & 112.16 & 121.54 & 54.48 & & 0.64 & 1.28 & 3.92 & 111.52 & 120.25 & 50.56 \\
\hline MMPAO & & 47.85 & 89.90 & 288.47 & & 59.99 & 120.09 & 367.65 & -12.14 & -30.19 & .79 .19 \\
\hline MUAEAR & & 6.48 & 61,11 & 1929.69 & & 0.73 & -1.45 & 4.45 & 5.76 & 59.65 & 1925.24 \\
\hline & TOTAL GA UWV. (BO) & 194.00 & 480,54 & 2278.89 & & 276.82 & 354.18 & 1696.65 & .82 .82 & .73 .64 & 582.23 \\
\hline
\end{tabular}




\begin{tabular}{|c|c|c|c|c|c|c|c|c|c|c|c|}
\hline \multirow[t]{2}{*}{ Stralegy 4. U. BounD } & \multirow{2}{*}{$\begin{array}{l}\text { HIGH GROWTH OF RATE } \\
\text { MIX (YAMTCE) }\end{array}$} & & & & \multicolumn{2}{|c|}{ BUSINESS AS USUAL } & & & \multirow[b]{3}{*}{$(\mathbf{B S} / \mathrm{GW}) \mathbf{G}$} & \multirow[b]{3}{*}{$(1+r+0)$} & \multirow[b]{3}{*}{ Lanamaro } \\
\hline & & & & & \multicolumn{2}{|c|}{$\begin{array}{l}\text { BUSANESS AS USUAL } \\
\text { MIX (YAMCTE) }\end{array}$} & & & & & \\
\hline YEAR & 1990 & 2000 & 2010 & 2025 & 1990 & 2000 & 2010 & 2025 & & & \\
\hline COAL & 72.27 & 72.27 & 72.27 & 72.27 & 72.27 & 72.27 & 72.27 & 72.27 & $\begin{array}{r}1.106 \\
\end{array}$ & 0.2212 & 1.3212 \\
\hline$\underline{\alpha}$ & 7.3 & 7.3 & 7.3 & 7.3 & 7.3 & 7.3 & 73 & 7.3 & 0.79 & 0.2212 & 1.0112 \\
\hline MATUPUL GAS & 0.41 & 0.41 & 0.11 & 0.41 & 0.41 & 0.41 & 0.41 & 0.41 & 0.527 & 0.2212 & 0.7402 \\
\hline HMORO & 20.01 & 20.01 & 20.01 & 20.01 & 20.01 & 20.01 & 20.01 & 20.01 & 1.216 & 0.2212 & 1.4372 \\
\hline MQAEAR & 0.2 & 0.2 & 0.2 & 0.2 & 0.2 & 0.2 & 0.2 & 0.2 & 1.52 & 0.2212 & .8412 \\
\hline & & & & & & & & & & & \\
\hline OEMANO (TIMES BASELLWE) & 1.00 & 1.85 & 5.33 & 13.74 & 1.00 & 2.10 & 4.48 & II.51 & & & \\
\hline TOTAL CAPACTY IGM & 137.89 & 254.65 & 734.32 & 1894.09 & 137.89 & 300.56 & 618.06 & 1587.47 & & & \\
\hline & CAPACTY BY FUEL (GM & & & & & & & & & & \\
\hline COAL & 99.65 & 184.04 & 530.69 & 1368.86 & 99.65 & 217.22 & 446.67 & 1141.27 & & & \\
\hline $\mathrm{a}$ & 10.07 & 18.59 & 53.61 & 138.27 & 10.07 & 21.94 & 45.12 & 115.89 & & & \\
\hline MATURAL GAS & 0.57 & 1.04 & 3.01 & 7.77 & 0.57 & 8.23 & 2.53 & 6.51 & & & \\
\hline MMOAO & 27.59 & 50.96 & 146.94 & 379.01 & 27.59 & 60.14 & 123.67 & 317.65 & & & \\
\hline MOEAR & 0.28 & 0.51 & 1.47 & 3.79 & 0.28 & 0.60 & 1.24 & 3.17 & & & \\
\hline & & & & & & & & & & & \\
\hline & NET INVT. BY FUEL (GM & $1990-2000$ & $2000-2010$ & 2010.2015 & & & & & & & \\
\hline COAL & & 84.38 & 346.66 & 838.16 & & 117.56 & 229.45 & 700.60 & & & \\
\hline oL & & 8.52 & 35.02 & 84.66 & & 11.88 & 23.18 & 70.77 & & & \\
\hline MATURAL GAS & & 0.48 & 1.97 & 4.76 & & 0.67 & 1.30 & 3.97 & & & \\
\hline MOPO & & 23.36 & 95.98 & 232.07 & & 32.55 & 63.53 & 193.98 & & & \\
\hline MUaEAP & & 0.23 & 0.96 & 2.32 & & 0.33 & 0.63 & 1.94 & & & \\
\hline & TOTAL NET MW & 116.98 & 480.58 & 1161.97 & & 162.98 & 318.10 & 971.26 & & & \\
\hline & NET INVT BY FUEL (BO) & & & & & & & & $\operatorname{INV}(A \cdot U) \cdot \operatorname{INV} 18$ & ASUSUAL) & \\
\hline COAL & & 111.99 & 460.08 & 1112.41 & & 156.03 & 304.53 & 929.83 & $\begin{array}{r}-14.04 \\
\end{array}$ & 155.55 & 182.58 \\
\hline OL & & 8.62 & 35.41 & 85.61 & & 12.01 & 23.44 & 71.56 & -3.39 & 11.97 & 14.05 \\
\hline MATURALGAS & & 0.36 & 1.47 & 3.56 & & 0.50 & 0.97 & 2.97 & .0 .14 & 0.50 & 0.58 \\
\hline HMOPO & & 33.58 & 137.95 & 333.53 & & 46.78 & 91.31 & 278.79 & .13 .20 & 46.64 & 54.74 \\
\hline MUCAEA & & 0.41 & 1.67 & 4.04 & & 0.57 & 1.11 & 3.38 & .0 .16 & 0.56 & 0.66 \\
\hline & TOTAL NET INV. (BD) & 154.96 & 636.58 & 1539.15 & & 215.80 & 421.35 & 1206.53 & .00 .93 & 215.23 & 252.62 \\
\hline & GROSS NVT. BY FUEL IGM & & & & & & & & & & \\
\hline COAL & & 117.57 & 407.94 & 1103.51 & & 150.75 & 301.79 & 923.93 & & & \\
\hline $\mathrm{O}$ & & 11.08 & 41.21 & 111.47 & & 15.23 & 30.48 & 93.33 & & & \\
\hline MATURAL GaS & & 0.67 & 2.31 & 6.26 & & 0.86 & 1.71 & 5.24 & & & \\
\hline MOPO & & 32.55 & 112.95 & 305.54 & & 41.74 & 83.56 & 255.82 & & & \\
\hline MUEAP & & 0.33 & 1.13 & 3.05 & & 0.42 & 0.84 & 2.56 & & & \\
\hline & TOIAL GROSS MW & 162.99 & 565.54 & +529.83 & & 200.99 & 418.37 & 1280.87 & & & \\
\hline & GROSS INY aY FUEL (BO) & & & & & & & & $\operatorname{INV}(4-U) \cdot \operatorname{INV}(B$ & IASUSUAL & \\
\hline COAL & & 156.04 & 541.42 & 1164.58 & & 200.07 & 400.53 & 1226.24 & $\begin{array}{r}-44,04 \\
\end{array}$ & 940.89 & 238.34 \\
\hline $\mathrm{OL}$ & & 12.01 & 41.67 & 112.71 & & 15.40 & 30.82 & 94.37 & -3.39 & 10.84 & 18.34 \\
\hline MATURAL GAS & & 0.50 & 1.73 & 4.68 & & 0.64 & 1.28 & 3.92 & .0 .11 & 0.45 & 0.76 \\
\hline IMOMO & & 46.78 & 162.33 & 439.12 & & 59.99 & 120.09 & 367.66 & -13.20 & 12.24 & 71.46 \\
\hline MUAEAR & & 0.57 & 1.97 & 5.32 & & 0.73 & 1.45 & 4.45 & .0 .16 & 0.51 & 0.87 \\
\hline & TOTAL GA INY. (BD) & 215.89 & 749.12 & 2026.41 & & 276.82 & 554.18 & 1696.65 & .00 .93 & 194.94 & 329.76 \\
\hline
\end{tabular}

